Historic, Archive Document

Do not assume content reflects current scientific knowledge, policies, or practices. 

62.11 INERXED

\section{TheWesternSeed 區} rom
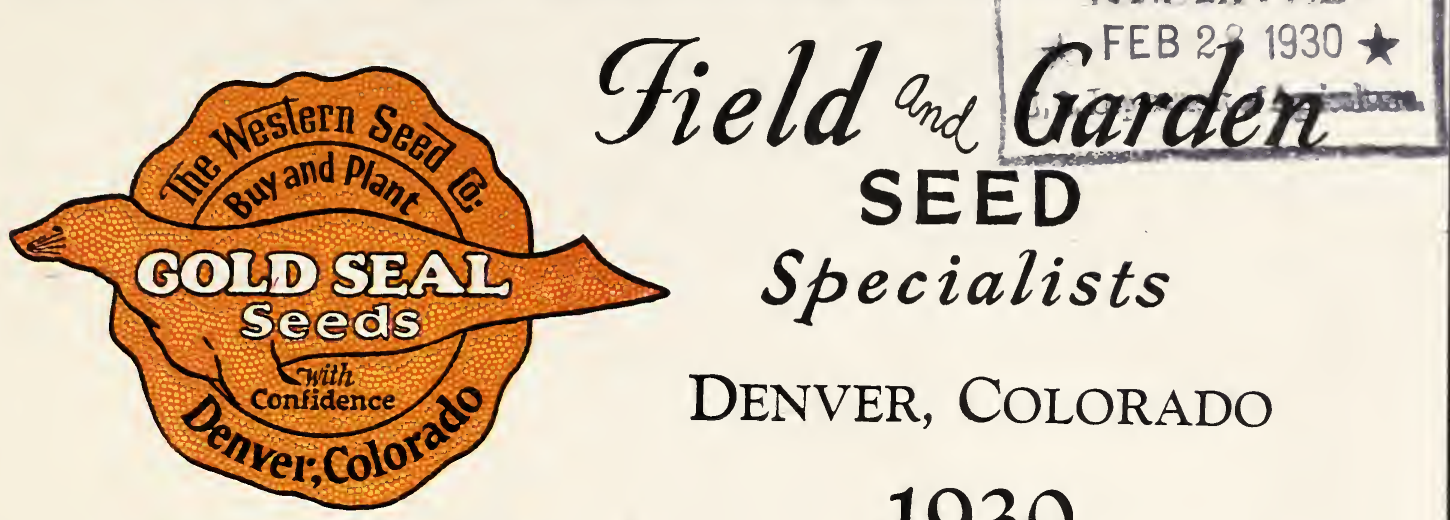

Buy and Plant Gold Seal Seeds Specialists

Denver, Colorado

1930

\section{with Confidence}

tiofers

intest

Whe?

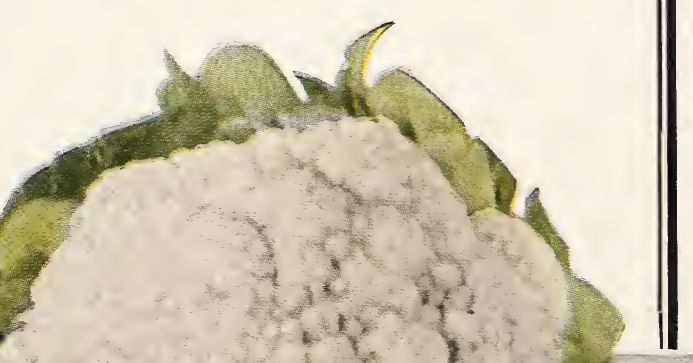




\section{[GREELEY WONDER] OR GOLDEN QUEEN}

Especially desirable for the market gardener and the home garden.

Selected seed, pkt., 10c; oz., $15 \mathrm{c} ; \mathrm{x} / 4 \mathrm{lb}, 40 \mathrm{c}$; 1 lb., $\$ 1.50 ; 5$ lbs., $\$ 1.35$ per lb., postpaid.

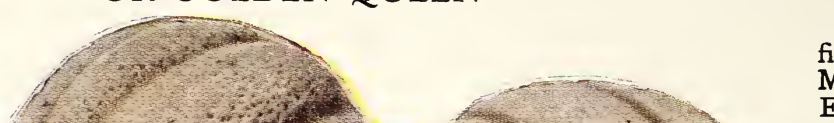

Very early, fine flavored Muskmelon. Extra heavy yielder. Melons large.

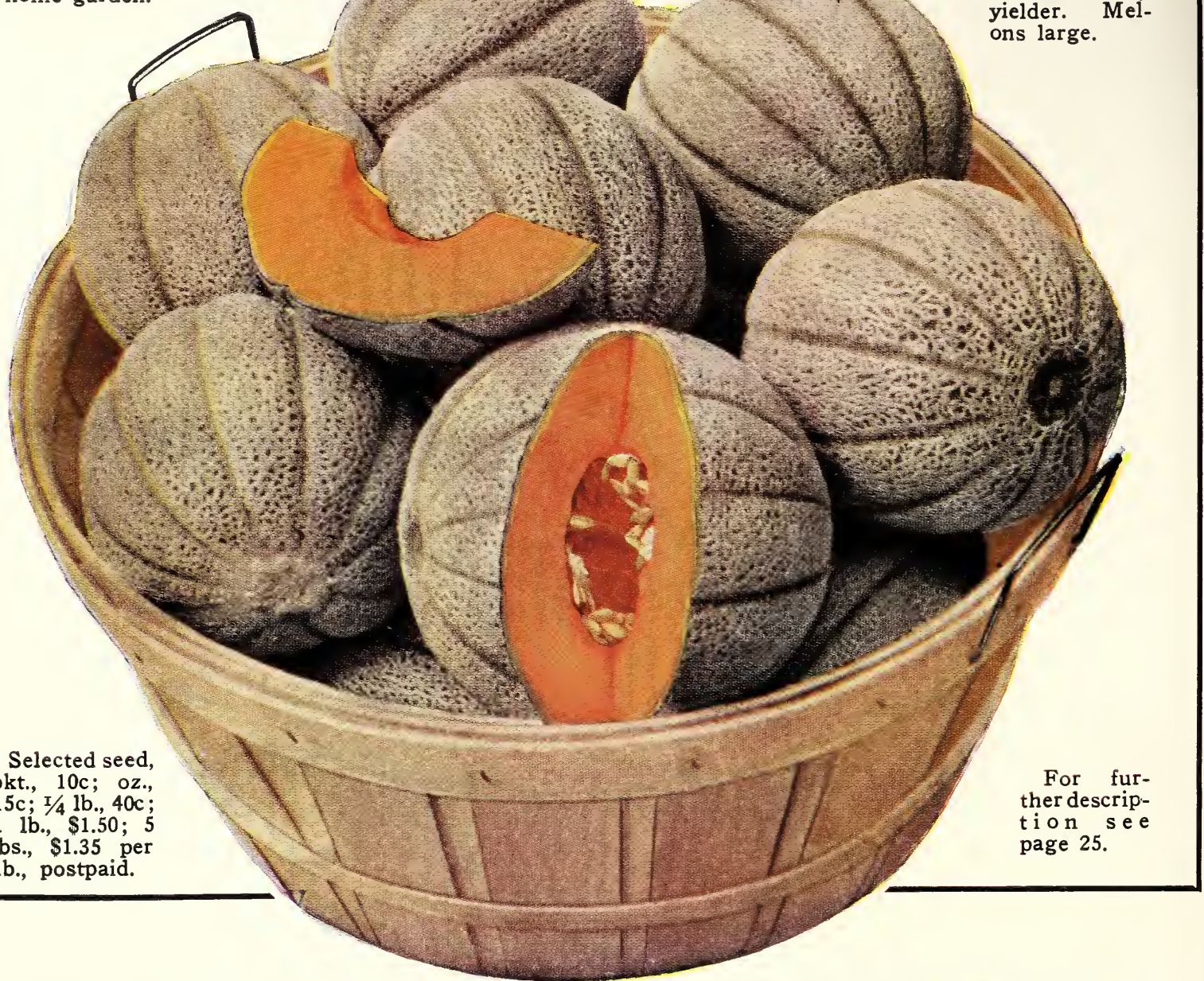

\section{JUMBO SUGAR WATERMELON}

A large, sweet, luscious Melon, dark green shell with bright, solid flesh of exceptionally fine texture. Contains one-third more sugar than Tom Watson. Price, packet, 10c; oz., 15c; $1 / 4$ lb., 50c; $1 / 2$ lb., $85 \mathrm{c} ; 1$ lb., $\$ 1.65$, postpaid.

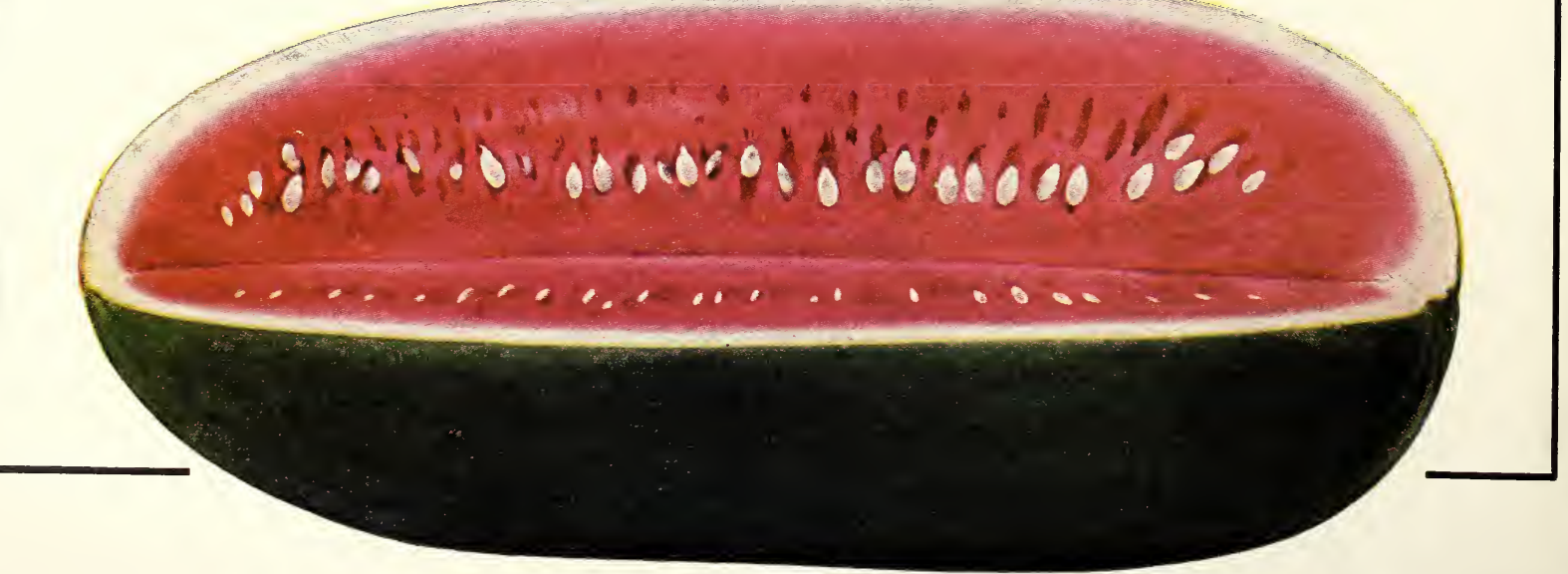




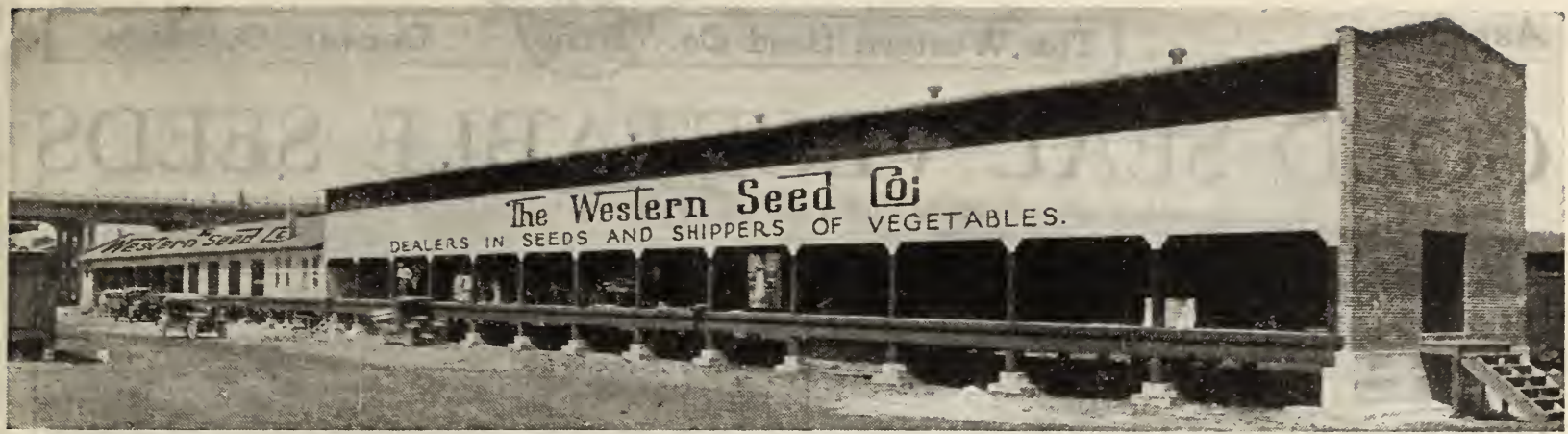

One of Our Vegetable Packing Warehouses Where Hundreds of Cars of Vegetables are Bought and Shipped by Us

\section{Why You Can Buy and Plant With Confidence Our Gold Seal Seeds}

Besides our earnest desire to sell seed of the best quality and germination, it is also necessary that we sell the best as we do an enormous produce business, being one of the largest handlers of vegetables in the United States. Last season we and our subsidiary companies shipped over 2,800 carloads of Vegetables; consisting of practically every vegetable grown. These vegetables were produced from our Gold Seal Seeds. Quality vegetables are necessary in our business, so to have quality to ship we must give the growers quality seeds to plant.

For these reasons we spare no care or expense in the production of Gold Seal Quality seeds. There has never been a disappointment in Gold Seal quality. In producing the seed we sell, cost is no consideration. Our aim is to produce the best-in fact, we must produce and sell the best quality seed.

Every lot of Vegetable, Flower and Field Seed we send out is also tested for germination by us shortly before they are sent out.

\section{Notice to Buyers of Field Seeds}

Quantity prices on field seeds are not stated for the reason that they cannot be accurately determined at the time the catalog is printed. As field seeds move in larger volume than garden seeds, stocks and markets are constantly changing. We, therefore, issue price lists to accommodate these conditions and they will be mailed on request to interested parties requesting same.

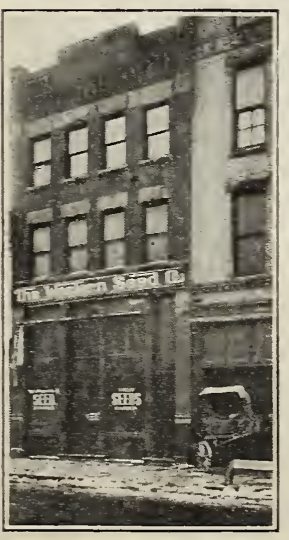

Our Guarantee

Our seeds, plants and nursery stock are sold to you with the express understanding that if they are not as represented and not fully satisfactory when you receive them, we will take them back and CHEERFULLY REFUND YOUR MONEY. But as there are so many outside influences over which we have no control-such as weather conditions-we cannot guarantee a crop.

Don't Forget to Read About Our FREE OFFER. See Page 58.
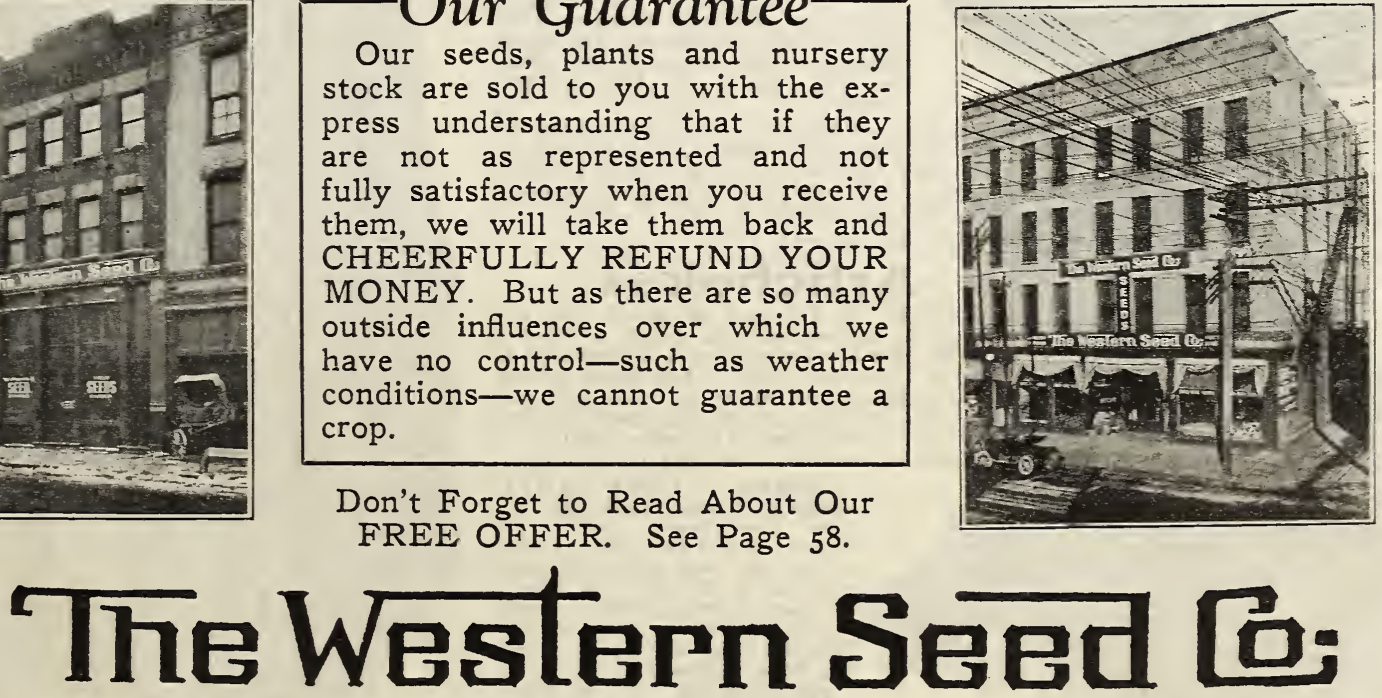

ELMER HARTNER, President - DENVER, COLORADO - R. E. PATTERSON, Mgr. 


\section{GOLD SEAL VEGETABLE SEEDS}

For many years the high quality of our vegetable seeds has been known to the majority of planters and they buy and plant Gold Seal Seeds confident that they are as represented.

\section{Read About Our New Mountain Head Lettuce, Peas, Cauliflower} (SEE BACK COVER)

The growing of these crops in our Mountain Districts has now become a permanent industry that has proved and will prove profitable for many and disastrous for some. Proper care and study in the selection of the ground and its accessibility and a knowledge of how to plant and handle the crop are necessary, besides a good grade of seed. Don't be fooled into buying cheap lots of seed from irresponsible parties.

\begin{abstract}
Garden for Health as Well as Profit
The home garden should not only be viewed from a point of profit and saving, but greater benefits by ten times are derived from the standpoint of health.

Either fresh fruits or vegetables should be in daily use in every home. They constitute not only a delicious and appetizing food, but as science has proved-a food indispensable to health. While to the majority of us fresh fruits and vegetables are not a part of our daily diet, due to being out of season or too remote from source of supply, yet almost everyone can produce their seasonable needs with little expense from their own garden.
\end{abstract}

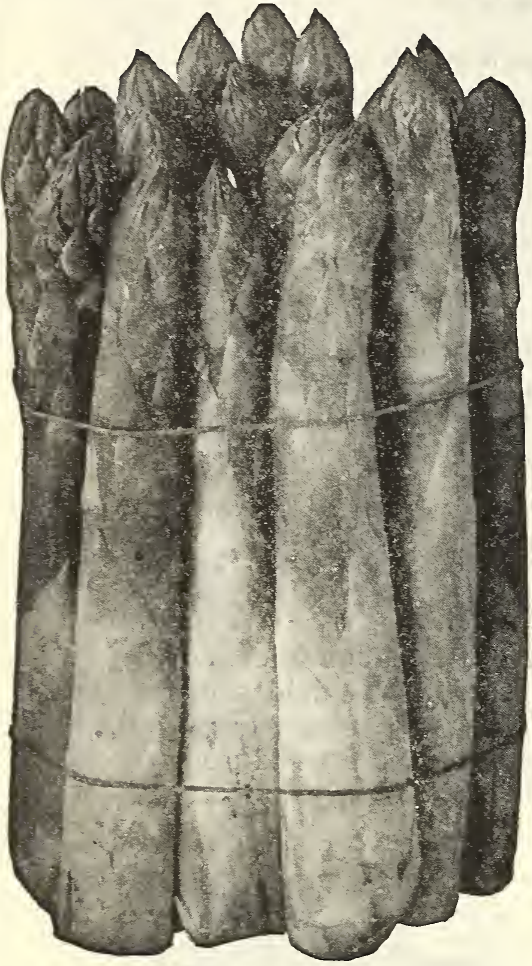

Mary Washington Asparagus.

\section{Asparagus Seed}

ASPARAGUS CULTURE. Plow your plot deep, then loosen up your soil, making \& perfect seed bed. Sow your seeds thick in rows 20 to 24 inches apart. Use plenty of water for the seed has a hard hull that can only be softened with moisture. After the plants start growing you must not cultivate, as this will injure the roots, and these roots are needed to produce the wholesome, crisp asparagus that is served on your table. (The roots needed to produce the wholesome, crisp asparagus that is served on your table. (The roots are what you grow from the seed). The following Spring the roots must be dug, separated and transplanted in the field, or garden, where you intend to raise your asparagus each following year. As the roots get older and larger the asparagus comes thicker and
better. If you do not care to wait and raise your own roots we can supply you with one or two-year-old roots of any variety listed.

MARY WASHINGTON. The Department of Agriculture has devel. oped two strains of Washington Asparagus; that is Martha Washington and Mary Washington, but the latter has proven to be the most highly rust resistant, and most highly rust resistant, and most The shoots are long, straight, thick. and heavy; dark green the entire length, except tinted darker at the tips. Pkt., $10 \mathrm{c}$; oz., $20 \mathrm{c} ; 1 / 4$ lb., $65 \mathrm{c}$; lb., $\$ 2.00$, postpaid.

EARLY GIANT FRENCH AR GENTEUIL (Gold Seal Quality) This early variety was first imported and sold on this market by us. Its superior quality has placed it ahead of all others. Dark green, large shoots, far more productive than the old sorts, which makes it preferred on all markets. Pkt., 5c; oz., 10c; $1 / 4$ Ib., 30c; 1 lb., $85 \mathrm{c}$, postpaid.

PALMETTO. This has been the most popular variety for general gardening purposes. Matures early. very prolific, producing an abundance of deep green shoots. Pkt., 5c; 0z., 10c; 1/4 lb., 25c; lb., 80c postpaid.

GIANT SNOW CAP. While the green varieties of Asparagus are very popular in most sections, this is largely due to the fact that the white varieties heretofore have been small and somewhat tough. But in this new introduction, Giant Snow Cap, w offer a large white, tender, prolific sort which will find favor even with the growers who are partial to the green varieties. Pkt., 10c; oz, 20c; 1/4 lb., 50c; lb., \$1.75. ASPARAGUS ROOTS. See page 42.

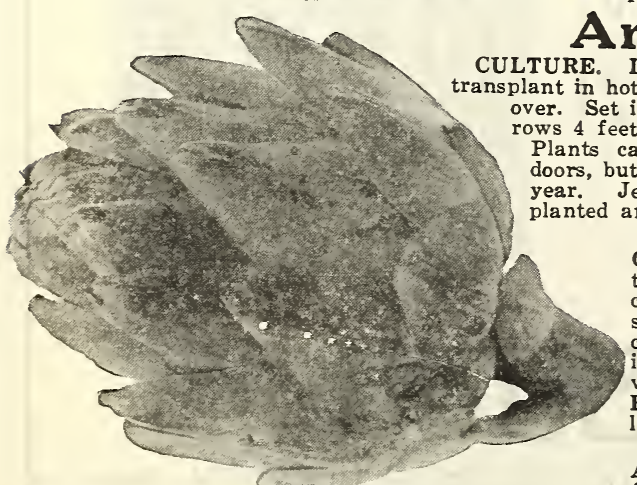

Artichokes

CULTE. In February or March sow and Ineds until the danger of frost is in very rich, well drained soil in (a) 4 feet apart and 2 feet apart in row. oors, but will not produce heads the first Jear. Jusalem Artichokes should be nd cultivated like potatoes.

GREEN GLOBE ARTICHOKES. Are cultivated for their flower-heads, which for cooked like asparagus. Plants cooked like asparagus. Plants set in any good soil, with light covering in Winter, will remain in bearing several years. Cultivation limited in this section lb., $\$ 5.00$, postpaid. JERUSALEM or POTATO
ARTICHOKE. A dandy hog Green Globe Artichoke. feed, heavy bearer. See pages 34 and 42 .

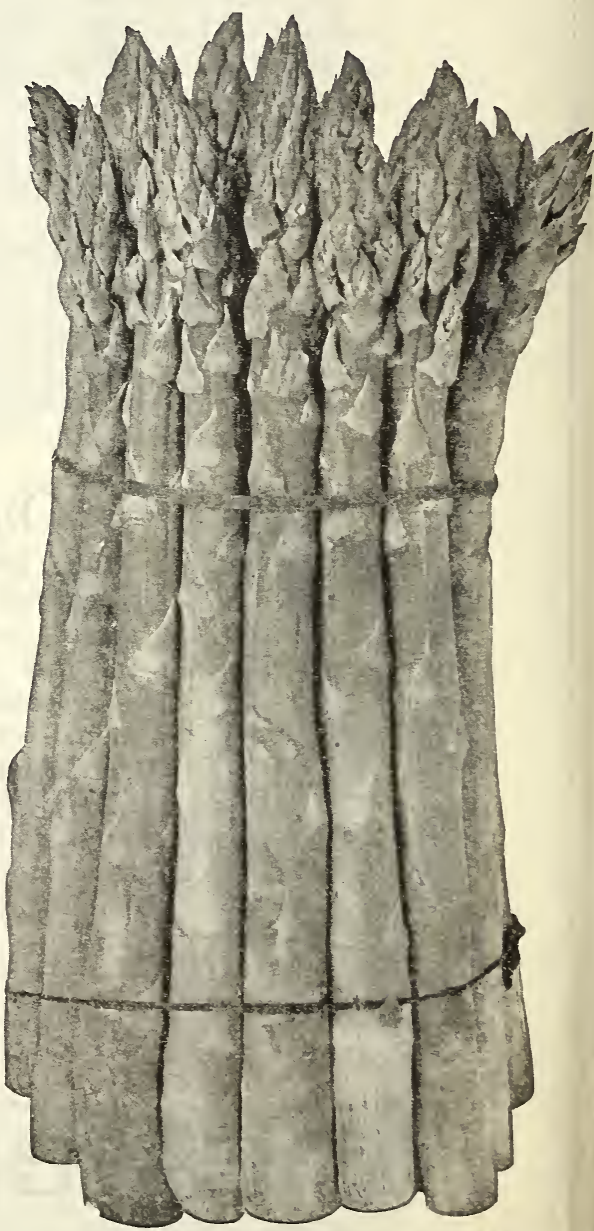

Early Giant French Argenteuil Asparagus. 


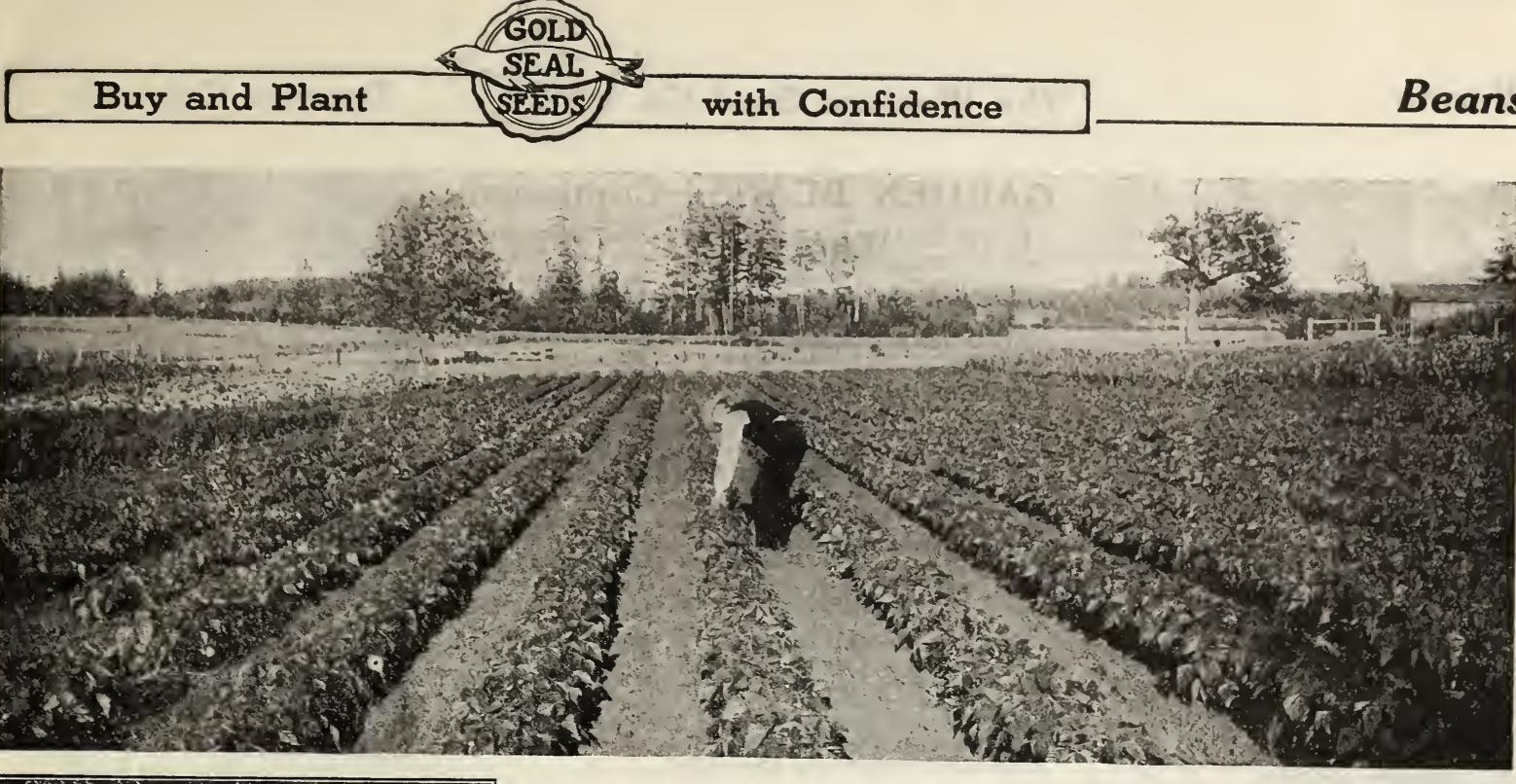

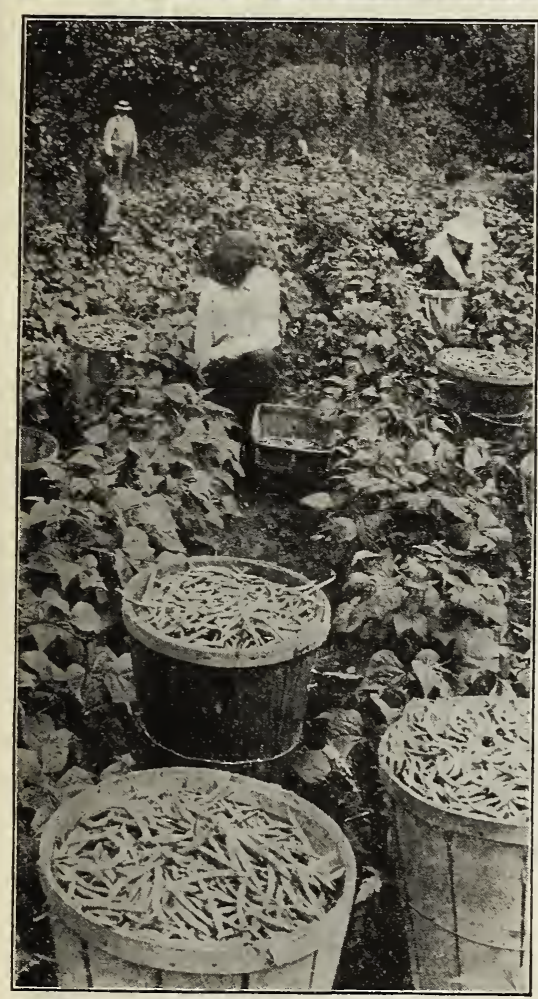

Full Measure Beans.

\section{Garden Beans}

CULTURE. There is hardly a vegetable that contributes to the table as liberally as the snap bean. It is easy to grow and a heavy producer. Beans should be planted at intervals so that one may always have a fresh patch to depend upon.

For the best crops beans require good rich soil and frequent hoeing. The young plant are very tender and cannot withstand even slight frosts. The seed should not be planted until the soil has become well warmed and all danger of frost is over. Spade or plow deeply and plant in rows 2 feet apart, scattering the seed about 3 inches apart in the row, and cover 2 inches deep. Hoe frequently, but never when the foliage is damp from dew or rain. Hoeing should be done shallow so that the roots are not injured.

\section{Green Podded Varieties}

FULL MEASURE (Gold Seal Quality), While this is not a new variety, yet it is just being recognized as one of the finest beans that can be grown because besides being absolutely stringless, the shell or skin of the pods does not get tough, no matter how long the pods are allowed to remain on the bush. The texture of the pod never grows coarse, but remains tender and meaty until the bean is fully matured and ready to shell. Due to its fine quality and long pods, in the past 4 years it has become the leading and most satisfactory bean, both for local use and as a shippin variety. It is superior to Burpee's Stringless.

SHIPPERS' GREEN POD or LONGFELLOW. This is the bean planted so extensively by our market gardeners, as it produces a large crop of pods which find a ready sale to the shippers at an advanced price. It is an excellent keeper; better than the Burpee's String. less or Refugee. The pods are long and straight and lefs or Refugee. The pods are long and straight and are absolutely stringless, very tender and of highest are absolutely stringless, very tender and of highest flavor-eve
Stringless.

GIANT STRINGLESS. Exceedingly productive and very hardy. Matures a few days later than the Burpee's Stringless, but is slightly longer and more nearly pee's String

BURPEE'S STRINGLESS. The most popular bean grown, because it is almost stringless, of dwarf growth, plants very productive, quite early, pods cylindrical. Especially recommended for home gardens.

EARLY SIX WEEKS. This is a very productive bean pods are long a bout 5 inches, straight, handsome, rather light green and when young are of a good quality. This is early maturing and is much used for home gardens.

EXTRA EARLY REFUGEF. A very early round podded sort, having medium sized, fleshy pods. ines small and very productive; for early planting this is one of the best sorts.

RED VALENTINE. This is an old, well known variety, very productive. Pods are long, green, straight and perfectly round. The quality is also good, pods being decidedly tender. Suitable for early and late planting, being extremely sturdy.

\section{PRICES-GREEN PODDED VARIETIES}

Bean seed is very scarce this season. We receipt of your order. Pkt., 5c; $1 / 2$ lb., $25 c ; 1$ lb., 45c; 5 lbs., $\$ 2.00$, postpaid. For larger amounts get special prices.

\section{Wax Podded Varieties}

ROUND POD KIDNEY WAX-BRITTLE WAX. A very handsome midseason variety, especially desirable for snaps for home garden. The plants are of strong growth, spreading and very productive. curved, light yellow, wax-like, stringless and of the very best quality. Seed long, cylindrical, medium sized, nearly white with a little dark markings about the eye. We especially recommend this bean fo the gardener-it is also an excellent shipping variety.

PENCIL POD BLACK WAX. Pods are long, thick, and fleshy and stringless.

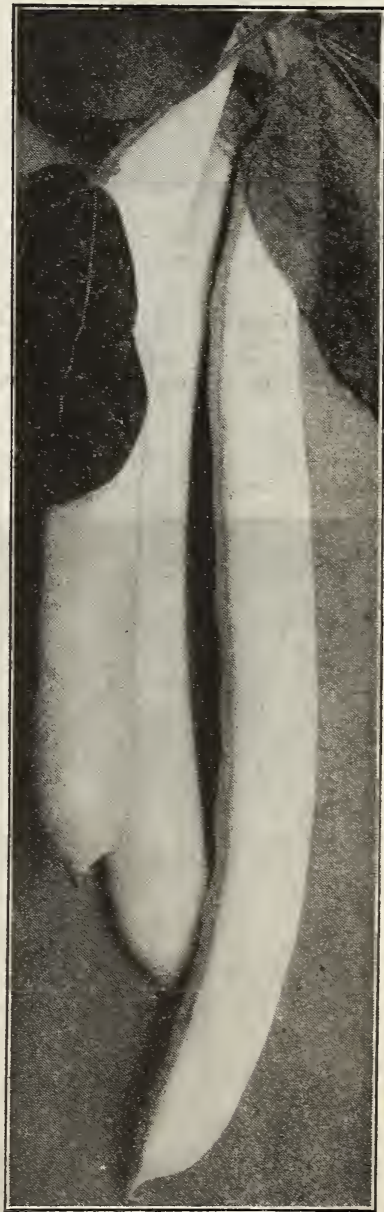

Round Pod Kidney Wax Beans. 


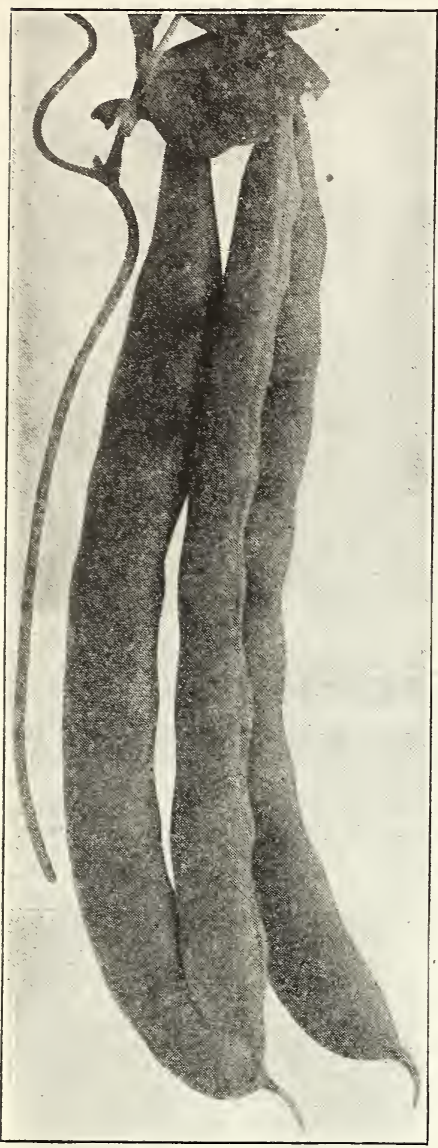

Kentucky Wonder Pole Beans.

\section{GARDEN BEANS-Continued}

DAVIS WHITE WAX. A white-seeded Golden Wax Bean of superior quality, extremely early and of great productiveness. The plant grows larger than the Golden Wax and produces an abundant crop of large, meaty, flat pods, which are of a bright golden-yellow color, exceedingly attractive and very uniform in size color, exceedir
and shape.

CHALLENGE DWARF BLACK WAX. This bean is a favorite among the growers who grow beans for the early market, as it is the earliest of the round wax varieties. The vine is strong, holding the pods well up, which are of a nice bright yellow color.

GERMAN BLACK WAX. Vines medium size with small foliage, very vigorous, hardy, and productive, maturing about midseason; pods are medium length, borne well up from the ground, are curved, cylindrical, fleshy, and of a cream white color. It remains a long time in condition for use as snaps.

OLD-FASHIONED GOLDEN WAX. This bean is the grand old wax-podded variety that has been planted by gardeners, both large and small, for many years. It is a heavy producer and very seldom fails to give the best results, even when some of the other varieties the best results, even when some of the other varieties
fail. The pods are long and semi-round, of rich golden cream color, very meaty and tender.

IMPROVED GOLDEN WAX. One of the old popu-

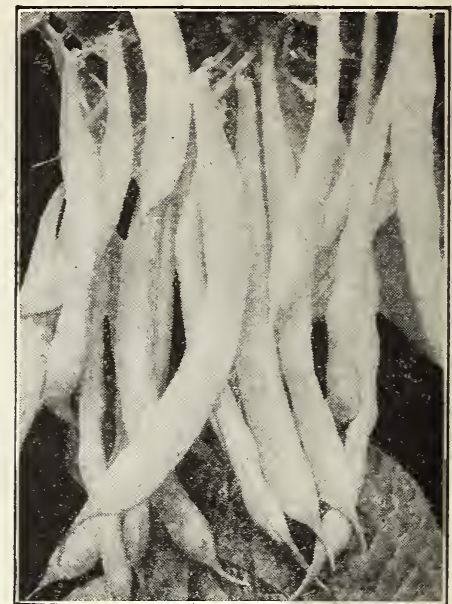

Shipper's Wax Pod Beans. lar varieties; pods straight, flat, and golden in color.

SHIPPERS' WAX POD. Pods long, round, straight, thick, and absolutely stringless. This variety has proved the best shipper, and we cannot recommend it too highly to market gardeners. It holds up well and is of fine appearance.

\section{PRICES-WAX PODDED VARIETIES}

Bean seed is very scarce this season. We can only fill orders on such varieties as we have unsold at time we receive your order. Pkt., 5c; 1/2 lb., 25c; 1 lb., 45c; 5 lbs., $\$ 1.90$; 10 lbs., $\$ 3.50$, postpaid. For larger amounts get special prices.

\section{Pole Beans}

KENTUCKY WONDER (Green Pod). This standard variety of Green Podded Pole Beans became popular through its rapid growth and abundant yielding qualities. It has been successfully grown in every section of the United States. Being extensively urow as exy section used as a corn bean, the pods are exceptionally long and often measure 10 to 12 inches, perfectly round and stringless when young. A good sort to plant around fences, for it will climb and dried, beans are good for winter use. Price, postpaid: Pkt., 5c; large size package, $10 \mathrm{c}$; $1 / 2 \mathrm{lb} .20 \mathrm{c} ; 1 \mathrm{lb}$. $35 \mathrm{c} ; 5$ lbs., \$1.60; $10 \mathrm{lbs} ., \$ 3.00$. If by express or freight, purchaser paying charges, 5c per pound less.

KENTUCKY WONDER WAX (Pole). The best wax podded pole bean. Vines are strong, producing pods 6 to 8 inches long, coming in very abundant clusters, pods very broad, thick, and fieshy, of golden yellow to creamy white. Postpaid, pkt., 5c; large size package, $10 \mathrm{c} ; 1 / 2 \mathrm{lb} ., 20 \mathrm{c} ; 1 \mathrm{lb} ., 35 \mathrm{c} ; 5 \mathrm{lbs} ., \$ 1.60 ; 10 \mathrm{lbs}$., $\$ 3.00$. If by express or freight, purchaser paying charges, $5 \mathrm{c}$ per pound less.

\section{Shell Beans}

DWARF HORTICULTURAL (Shell Beans), Very productive, vines compact upright, with large leaves, pods medium length, round, curved, yellowish color, marked with splashes of red. The beans are fit for use

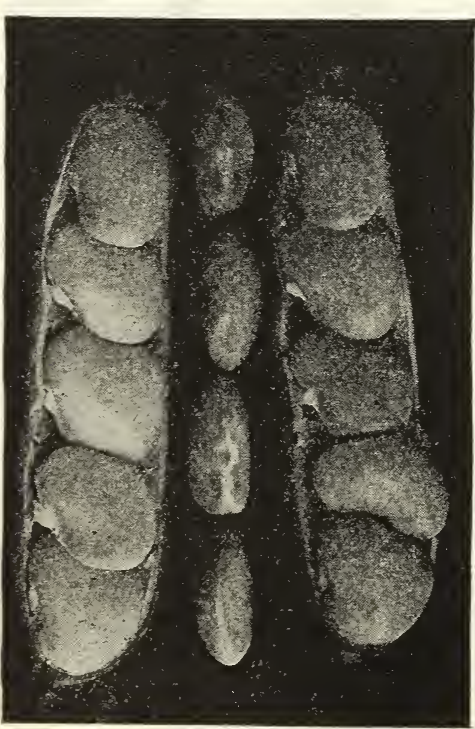

Henderson's Bush Lims Beans. color, marked with splashes of red. The beans are fit for use as green shell beans, very early, and in this condition the beans are very large and easily shelled, and are about equal $10 \mathrm{c} ; 1 / 2 \mathrm{lb} ., 20 \mathrm{c} ; 1$ lb., 35c; 5 lbs., $\$ 1.50 ; 10$ lbs., $\$ 2.75$. If by express or freight, purchaser paying charges, $5 c$ per pound less.

\section{Lima Beans}

HENDERSON BUSH IIMA. This is the earliest of the flat-pod limas and is much more satisfactory to grow in districts which have about the same climate as Denver. It is two weeks earlier than any other variety. They resemble the Burpee's in flavor and shape, but are only about one-third as large. As dry beans they are known as Baby Lima. Postlarge. As dry beans they are known as Baby Lima. Postpaid, pkt., 5c; large package, 10c; $1 / 2$ lb., $20 \mathrm{c} ; 1$ to., $35 \mathrm{c}$; chaser's expense, $5 \mathrm{c}$ per pound less.

AZTEC (Colorado or California Cream Butter). This wonderful (This wonby the Indians. It is the Lima generations in New Mexico tory; does well on dry landima Bean for the Western territory ; does well on dry land, and is earlier than other varieties. The seed is not flat like most Lima Beans, but round and about the shape of our small Navy Bean, but is 4 or 5 times larger. Can be used either as a green shell bean or dried. Postpaid, pkt., 5c; large package, 10c; $1 / 2 \mathrm{lb} ., 25 \mathrm{c}$; 1 lb., 40c; 5 lbs., $\$ 1.75 ; 10$ lbs., $\$ 3.00$. If by express or freight, at purchaser's expense, 5c per pound less.

BURPEE'S BUSH. The old standard Bush Lima Bean The bushes are 18 to 20 inches high, of stout, erect growth branch freely and are very prolific. The pods are well filled with large, fleshy beans of excellent quality. Delicate pale green in color and possessing that rich, buttery fiavor of the pole variety. Postpaid, pkt., 5c; large package, 10c; $1 / 2 \mathrm{lb}$., $25 \mathrm{c} ; 1 \mathrm{lb}$., $40 \mathrm{c} ; 5$ lbs., $\$ 1.75 ; 10$ lbs. $\$ 3.00$. If by express or freight. purchaser paying charges, $5 c$ per pound less.

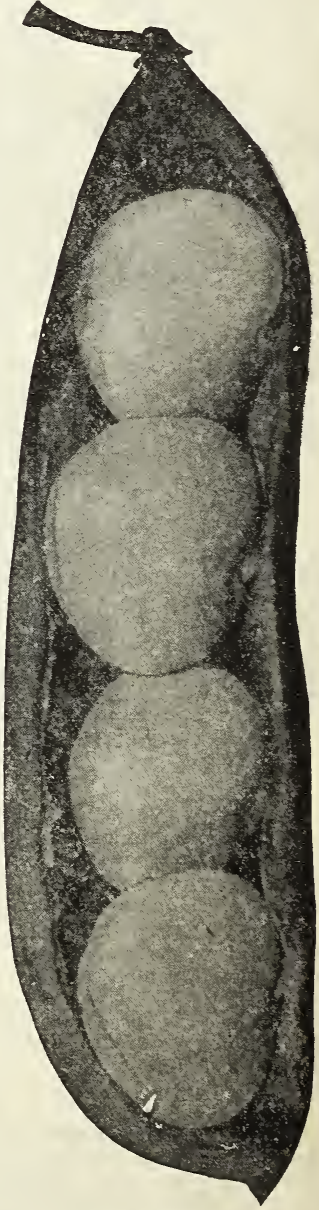

Burpee's Bush Lima Beans. [4] 


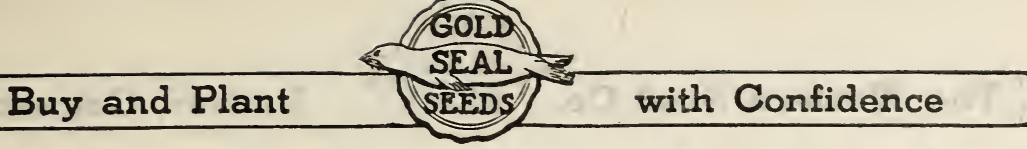

\section{Red or Table Beets}

\section{French Grown for Purity-Tested for Germination \\ PRICES ARE POSTPAID}

Our beet seed has proven the purest and best with which the market gardeners of this territory have been supplied. Many of market gardeners of this territory have been supplied. Many of them have made extra money by having the proper sort of beets at the right time. In former years, the planted for early and late crop, but now the buyers of beets demand a different kind at different seasons, which we offer and describe below.

CULTURE. Beets thrive best in deep, rich, sandy soil, one which the roots can penetrate easily. For extra early use, the seed may be sown in hotbeds and the young plants set out in the open, trimming off the outer leaves. They can be transplanted easily in moist weather. For early use, spade or plow deeply, sow seed in rows 18 inches apart, covering one-half inch deep. If dry, the soil should be well firmed about the seed. When three or four leaves have developed, thin out to four inches apart in the row, allowing the strongest to remain. Keep free from weeds. For main crop sow end of April. For Winter crop, sow end of June.

DETROIT DARK RED (Gold Seal Quality). The fact that this beet combines the fine shape of the Eclipse and the dark flesh of the Egyptian places it among the leading beets with the gardeners who plant for Winter use. This variety is not as early as Egyptian, but is the most uniform and best keeping beet. It is also a very attractive beet when bunched. Postpaid, pkt., 5c; oz., 15c; $1 / 1 \mathrm{Ib} ., 35 \mathrm{c} ; 1 / 2 \mathrm{lb} ., 60 \mathrm{c}$; $1 \mathrm{lb} ., \$ 1.10$.

EARLY CROSBY'S EGYPTIAN (Gold Seal Quality). The name of this variety is misleading, as it resembles the Egyptian only in its extreme earliness. This beet is more spherical in shape than the Early Egyptian, and we believe of a better quality, a distinct vermilion color and very attractive in appearance. One of the best for early planting in the open. Postpaid, pkt., 5c; oz., 15c; $1 / 4$ lb., 30c; $1 / 2$ lb., $55 \mathrm{c}$; 1b., $\$ 1.00$.

EXTRA EARLY EGYPTIAN (Gold Seal Quality). This is one of the best varieties for forcing and early planting. While young it is very $s$ weet and tender and oval ties for forcing and early plantio
in shape and presents a fine in shape and presents a fine for market, but with continued growth it become broader instead of oval and often too large and coarse for table use. It has been the standard variety for many years, as it is a good many years, as it is a good keeper when and stored away for the Winter flesh dark, blood red. Showy when the beet is cut. Postpaid, pkt., 5c; oz., 10c; $1 / 4$ lb.

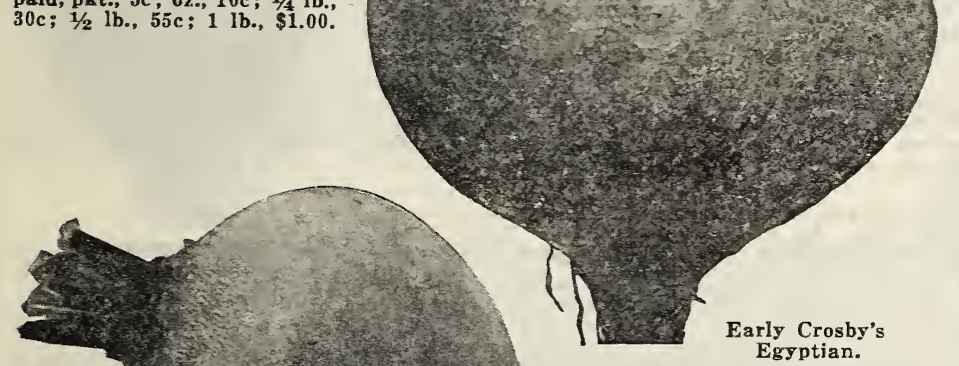

Egyptian.

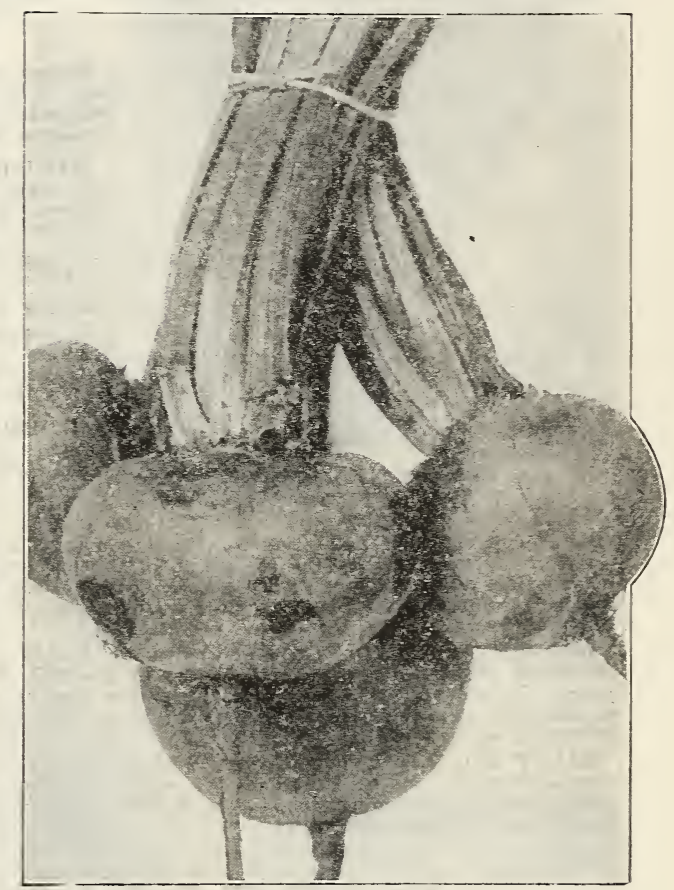

Extra Early Egyptian Beets.

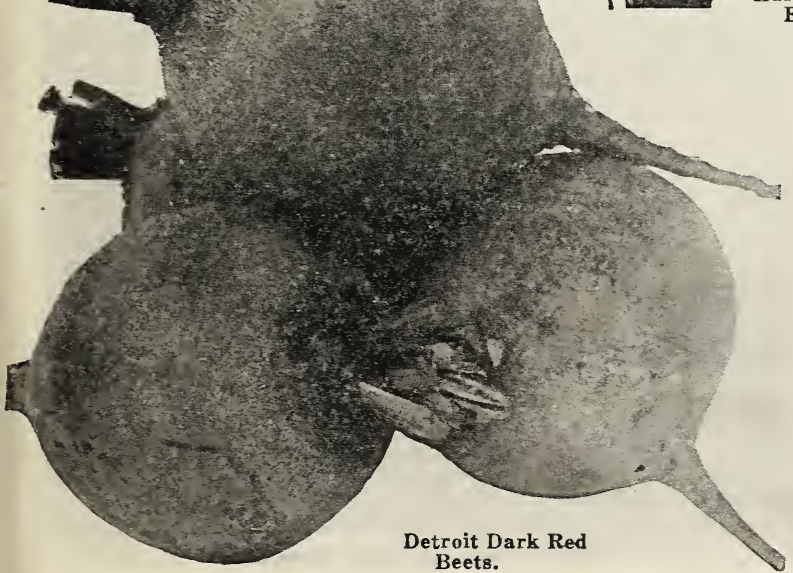

Beets.
EARIY ECLIPSE. We recommend this variety for midsummer at the time beets are sold by the bunch. Their color is brighter red than other sorts, which gives them a more tender appearance. But do not plant this variety to be sold in sacks during the Fall or winter months as it does not command the best prices at that time. It is of lighter color than the Detroit, and its rings or zones are paid, pkt., $5 \mathrm{c}$; oz., $10 \mathrm{c}$; $1 / 4$ lb., $30 \mathrm{c}$; 1/2 lb., 55c; 1 lb., $\$ 1.00$.

EARLY WONDER BEET. This new beet is becoming very popular with market gardeners who grow for the early market, as Early Wonder is the earliest variety of beet. It is vermilion-red; has small top ; is globe shaped and a money maker. It is deserving of a trial in your garden this year. Pkt., $5 \mathrm{c}$; oz., 15c; $1 / 4 \mathrm{lb} ., 30 \mathrm{c} ; 1 / 2 \mathrm{lb} ., 55 \mathrm{c}$ : $1 \mathrm{lb} ., \$ 1.00$.

EXTRA EARLY BLOOD. This beet is very early; ringed red and white, absolutely perfect in shape; roots are globular and peculiarly smooth; very crisp, tender, fine grained and sweet at all stages of its growth. Has small tops and can be used six weeks from sowing. Postpaid, pkt., 5c; oz., 10c; $1 / 4$ lb., 30c; 1/2 lb., 55c; 1 lb., \$1.00. 


\section{Splendid Winter Feed for Cattle, Hogs, Poultry, Sheep, Etc.}

\section{Our Seed is Danish Grown-Buy No Other}

CULTURE. Both Mangels and Sugar Beets require deep, well enriched soil. Sow in May and June in rows 18 inches to 2 feet apart and 6 to 8 inches in the row. Young plants may be transplanted to fill up vacancies. As soon as frost occurb, dig the crop. For Winter store in cellar or in pits.

\section{SUGAR BEETS}

Prices, all varieties, postpaid: Pkt., 5c; 1 oz., 10c; 1/4 lb.. 20c; $1 \mathrm{lb} ., 45 \mathrm{c} ; 5 \mathrm{lbs} ., \$ 2.00$; $10 \mathrm{lbs} ., \$ 3.50$. If by express or freight, purchaser paying charges, 5c per pound less. For larger a mounts, see Blue List.

WANZLEBEN. This is the variety so extensively planted for sugar manufacture. Although it does not yield quite as large crops as mangels, the feeding value, pound for pound, is much greater on account of its high percentage of dry matter content. Recommended especially for fattening cattle, but is equally well adapted for general feeding as mangels.

\section{MANGEL WURZELS}

Prices, all varieties, postpaid: Pkt., 5c; $1 / 4 \mathrm{lb}$., 25c; $1 \mathrm{lb}$., $60 \mathrm{c} ; 5$ lbs., $\$ 2.50 ; 10$ lbs., $\$ 5.00$. If by express or freight, purchaser paying charges, 5c per pound less. For larger amounts, see Blue List.

DANISH SLUDSTRUP. Contains more feeding value than any other mangel. The roots are large, reddish yellow, of distinct type and a remarkable yielder. Tests show it to contain as follows:

17 per cent more pounds of roots per acre than the Mammoth Long Red.

23 per cent more nutriment than the Mammoth Long Red. 22 per cent more pounds of roots per acre than the Golden Tankard.

28 per cent more nutriment than the Golden Tankard. Over 40 tons have been grown on a single acre

MAMMOTH LONG RED. This is a very large and heav mangel, Roots grow one-half to two-thirds above the soil and are often two or more feet in length and nine inches in diameter. Skin dark red, flesh white, with veined rings of pink.

GIANT HALF SUGAR. This is neither a mangel nor a sugar beet, but as the name implies is a cross between the two. It has the large size of the mangel with the great feeding quality of the sugar beet. It will yield almost as many tons per acre as the best mangels, twice as much as the sugar beet. It has become the most popular beet grown for stock feed. As all grains are now higher, more stock beets should be planted.

GOLDEN TANKARD. The best known and highly recommended for dairymen on account of its milkproducing properties and the rich quality of the milk. The flesh is firm and solid and a rich golden yellow color. On account of its peculiar shape they can be grown closer in the rows than most mangels, increasing the yield per acre considerably. Grows well above the ground and is easily pulled. Yields particularly well on light soil.

GIANT ECKENDORFER. A very popular variety, grown extensively in Germany. It has also proven very satisfactory in the United States wherever it has been tried. Its roots are very heavy. It has been known to produce as much as $\mathbf{5 5}$ tons of roots to the acre. This variety is very easily harvested, as a large portion grows above the ground.

\section{BROCCOLI}

ITALIAN GREEN SPROUTING. Rapidly becoming a very popular vegetable and especially adapted to Colorado. Culture is the same as Cauliflower but much easier grown.

A rapid grower producing bluish green heads in center of plant about 90 days after planting. After original head is cut, the plant produces many branches which also bear smaller heads.

It is usually served like Caulifiower but the flavor is distinct and has no similarity to Cauliflower. It is also cooked and served the same way as Asparagus.

Pkt., 10c; 1 oz., 70c; $1 / 4$ lb., $\$ 2.50 ; 1 \mathrm{lb} ., \$ 8.00$.

\section{SWISS CHARD}

LARGE WHITE RIBBED. Member of the beet family, is grown for the leaves only, and cooked like spinach. The mid-rib is prepared like asparagus. It is hardy and productive, with broad green leaves and large white midribs or chards of excellent quality, and can be sown at different seasons of the year, giving successive greens. Pkt., 5c; 0z., 10c; $1 / 4$ lb., 30c; 1 lb., $90 \mathrm{c}$.

LUCULLUS. A peculiarly delicious variety having yellow leaves which are remarkably crimped and curled, like savoy-leaved cabbage. The chards are white and broad but not so broad as the common variety although equally fine in flavor. Pkt., 10c; oz., 15c; $1 / 4 \mathrm{lb}$. $35 \mathrm{c} ; 1 \mathrm{lb} ., \$ 1.00$.

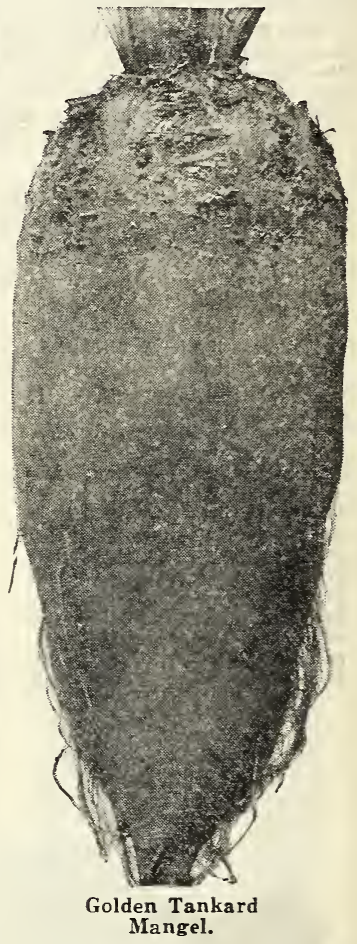

Italian Green Sprouting Broccoli. 


\section{Buy and Plant}

\section{Extra Early European Market \\ Cabbage}

Extra early cabbage pays well if you get a good yield. Most all extra early varieties of cabbage are very light yielders, but our European Market is both extra early and a heavy yielder. It is about five days earlier than the Copenhagen Market and it produces a very uniform crop of large round heads of nice green color. It is an excellent shipping variety. Year in and year out European Market is the most profitable cabbage that can be grown. Pkt., 15c; oz., 40c; $1 / 4$ lb., $\$ 1.50 ; 1$ lb., $\$ 5.00$.

\section{Copenhagen Market Cabbage GOLD SEAL QUALITY}

A splendid, new extra early, round head sort which matures about as early as the Wakefields, and is of much larger size. Each plant forms a perfect tight-folded head, averaging 5 to 8 pounds in weight, and about 8 inches in diameter each way. The compact growth of the plant, the solidity of the head, its excellent flavor and extreme earliness, all combine to make Copenhagen Market one of the most meritorious cabbages that has come to our notice during our experience in handling cabbage. We pronounce it,
without reserve, one of the finest and earliest round-headed

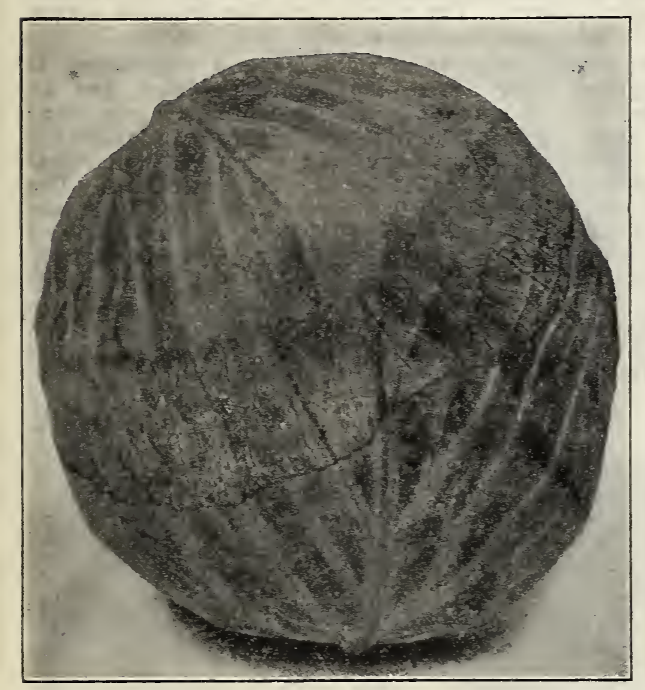

Copenhagen Market Cabbage. sorts in cultiva. tion today.

It is very popular with the market gardeners. It is a short-stemmed variety, the heads nearly resting on the ground. It is very desirable on account of the characteristic of maturing the heads all at the same time, thus enabling the grower to clean his fields at the first cutting. Heads are large, very solid, and of the most excellent quality. Gold Seal Quality. Postpaid, pkt., 10c; 1 oz., $40 \mathrm{c}$; $1 / 4 \mathrm{lb}$., $\$ 1.25$; 1 lb., $\$ 4.00$.

\section{Golden Acre Cabbage}

The Golden Acre is a new superior variety of early, round-headed cabbage, very closely resembling Copenhagen Market, but more fixed in type. It has qualities so valuable and important that, not since the advent of the "Jersey Wakefield" has a greater or more important Early Cabbage been offered.

We believe it is the earliest cabbage in existence. It matures in but 80 days from the date the seed is sown. The head begins to form when the leaves are no larger than a saucer and its growth may be observed almost from day to day. It is perfectly round and, full grown, measures 8 to 12 inches in diameter. The heads mature all at the same time-so fixed is the type, and one head is just like the other.

The plants can be set very close, as there are only about 12 leaves and these are very short. The stalk is less than two inches high. so that the plant is distinctly dwarf.

Seed grown by originator: Pkt., $10 \mathrm{c} ;$ oz., $45 \mathrm{c} ; 1 / 4 \mathrm{lb}$., $\$ 1.50 ; 1 b ., \$ 5.00$. Holland grown seed: Pkt., 10c; $1 / 2$ oz., $20 \mathrm{c}$; oz., 35c; $1 / 4 \mathrm{lb} ., \$ 1.25 ; 1 b ., \$ 4.50$.

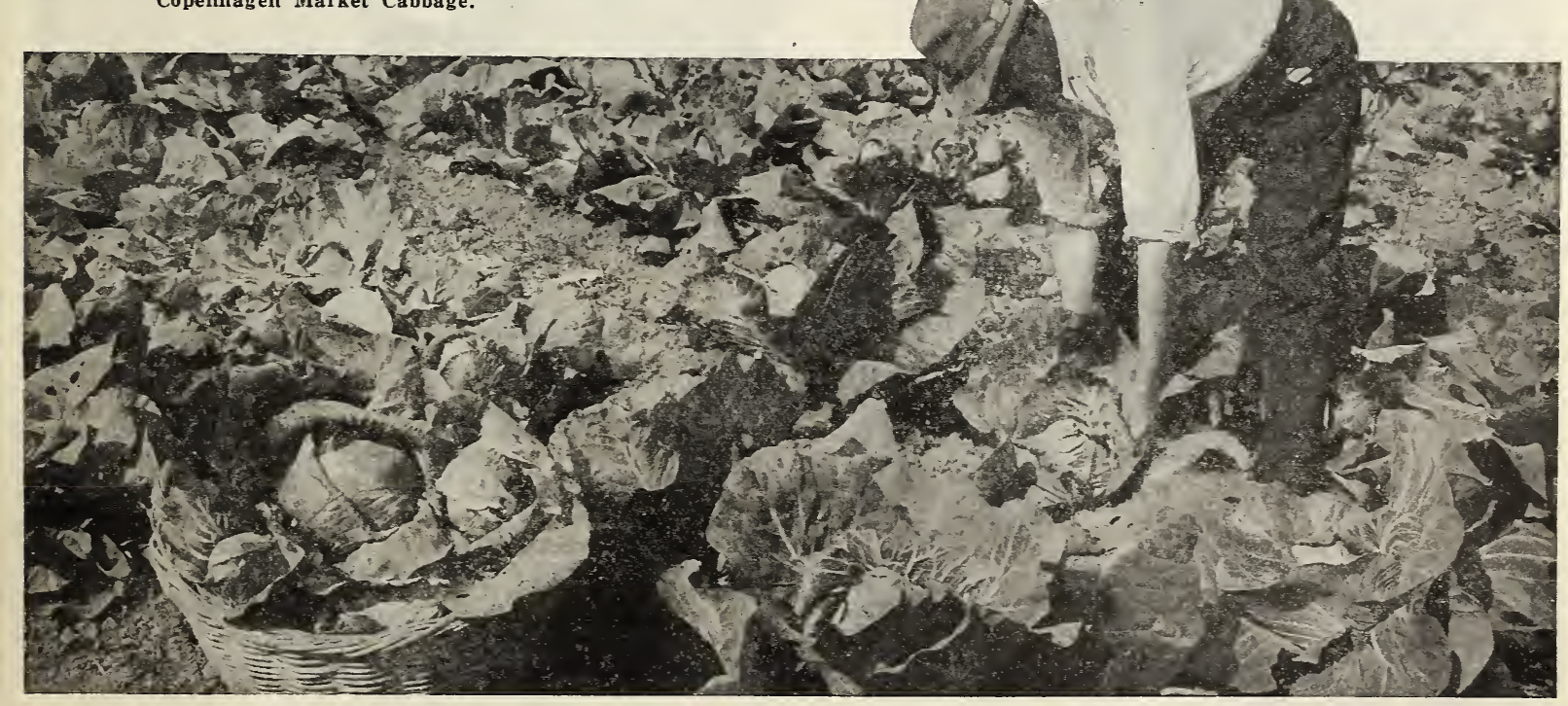




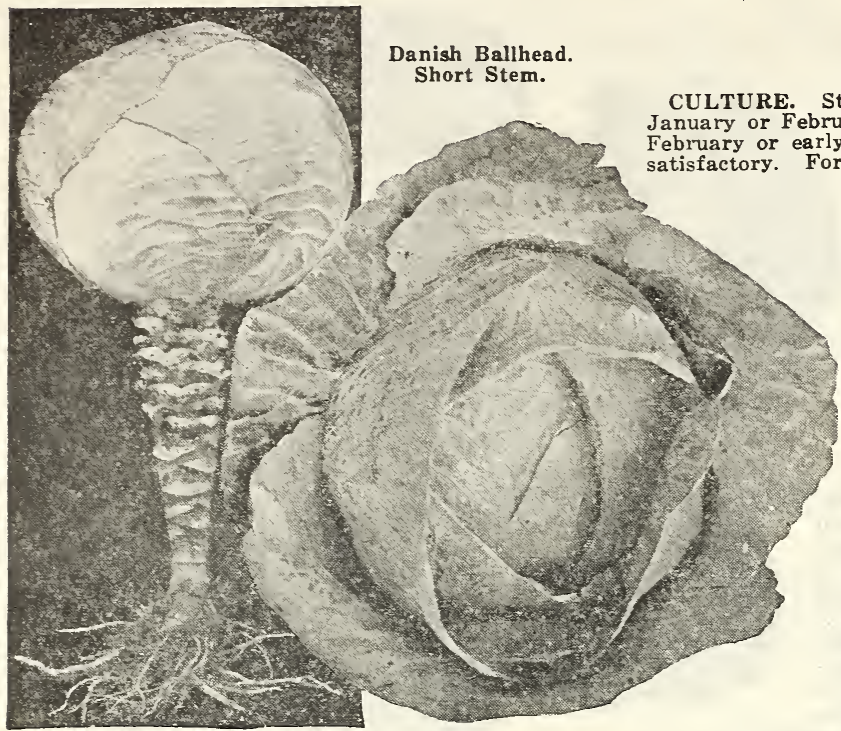

\section{Cabbage}

Start with good seed. For extra early use, seed may be sown in

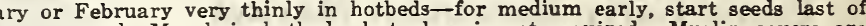

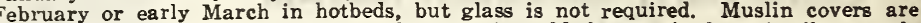
For late crop, start the seed in cold frames in late April or early May and not over one-fourth inch deep. Plants should be set in rows $21 \%$ to 3 feet apart and 12 to 18 inches in row.

of recent years a very satisfactory method has been to sow the seed right out in the field, the same as sugar beets and thin after the plants get three inches tall. This is much cheaper than growing in beds, and then transplanting to the fields, besides the plant is not retarded in its growth after being set to the field. While we sell cabbage plants, yet we advise you to grow your own, as transportation from one locality to another is never so satisfactory.

\section{Evergreen Hollander Cabbage Original Strain-Sold Only in Sealed Packages COLORADO'S MOST POPULAR LATE SHORT STEM CABBAGE}

Plant No Other-Buy No Other

EVERGREEN HOLLANDER CABBAGE. Is our own origination and we control the strain. It can only be secured from us and then only in sealed packages bearing our Gold Seal trade mark. If you buy this seed from us and with proper care and attention, do not raise the finest crop of Holland Cabbage you ever grew, we will refund your money. You cannot get the genuine strain except in Gold Seal packages.

EARLY JERSEY WAKEFIELD. For many years or until Copenhagen Market was introduced this was the leading early cabbage; a very satisfactory sort where an early, pointed head is desired. Pkt., 10c; oz., 25c; $1 / 4$ lb., 80c; 1 lb., $\$ 2.50$.

DANISH ROUNDHEAD, SHORT STEM (Gold Seal Quality). The Cabbage Grower's Friend. One of the grandest of all cabbages, and it is now more extensively grown throughout the United States than any other variety, and one year after another it has given the cabbage growers wonderful results. This one variety alone has done more to place Colorado among the leading cabbage states in the Union than all other varieties combined. It is just 16 years ago that this firm persuaded the growers of cabbage to try this variety instead of the old-fashioned Holland, the Drumhead and the Flat Dutch. The Danish Roundhead Short Stem never fails to produce a good crop of cabbage. This variety is inclined to grow on a very short stem and

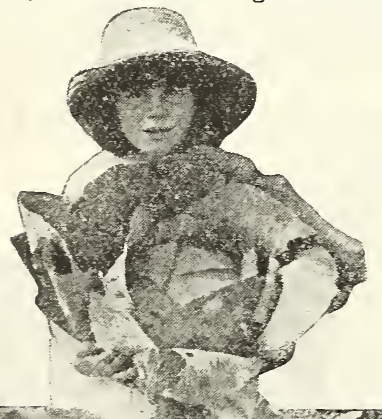
and produces rounded heads of a dark green color. When the seed is sown in the open, it matures about the last of September, while in the dry hot seasons it will mature about 2 weeks earlier. Recommended by us as a good heavy yielding main crop cabbage. Postpaid, pkt, 10c: 1 oz., 35c; $1 / 4$ lb., \$1.25. $1 \mathrm{lb} ., \$ 4.00$.

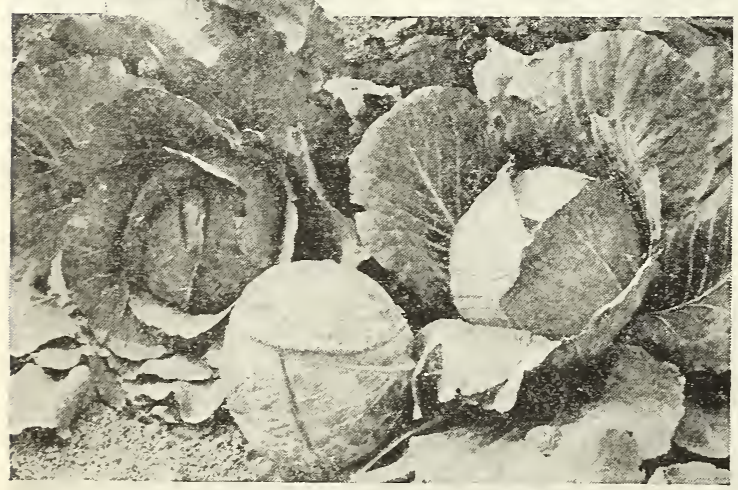

Danish" Round Head Short Stem.
Our experience, as a shipper of cabbage and vegetables, is that our Evergreen Short Stem Hollander Cabbage has no equal, and as we handle thousands of tons annually, our word may be relied upon. Evergreen Hollander excels in qualitythe heads are uniform, solid, heavy, and crisp. It will equal and outyield all other varieties under similar conditions. The instance has been known where twenty tons per acre was secured from good, strong ground with proper attention and handling. It has wonderful keeping qualities, and consequently is much sought after by carlot shippers. The rich, green color of the heads is retained as long as they exist. We have seen Evergreen Hollander taken out of pits as late as March 5th and the heads were as green as when buried. Prices, postpaid: Pkt., 15c; oz., 40c; $1 / 4$ lb., $\$ 1.40 ; 1$ lb., $\$ 4.50$.

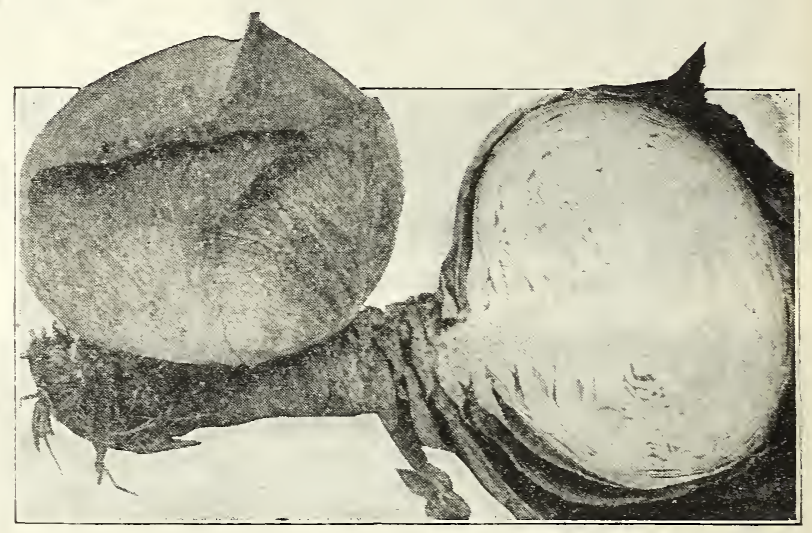

Evergreen Hollander.

GLORY OF ENKHUIZEN. This variety has now taken the position of the leading and most desirable midseason cabbage because it is very dependable as a crop producer. Heads are good size, solid, round in shape, good green color. It matures right after European and Copenhagen Market and just before the Hollander and Danish Roundhead. Our seed is grown for us in Holland by a specialist. Postpaid, pkt., 10c; 1 oz., 40c ; $1 / 4$ lb., $\$ 1.25 ; 1$ lb., $\$ 4.00$.

WISCONSIN DISEASE RESISTANT. In many districts late cabbage growers have trouble with their plants when about half grown, turning yellow, also decay developing in stems and roots, and plant wilting, which is commonly known as "ycllows." This strain of late cabbage, of true Holland type, was especially bred so as to be practically immune to this disease. Price, pkt., 15c; $1 / 2$ oz., 50c; $1 / 4$ lb., $\$ 1.50 ; 1$ lb., $\$ 4.00$. 


\section{Cabbage}

DANISH BALLHEAD SHORT STEM (Gold Seal Quality). A new type of cabbage introduced by us ten years ago and readily accepted by those who tried it as a very desirable sort for the late kind that can be put in the ground for midwinter use. If planted on good ground an enormous yield can be expected, for the heads, when matured, are all of a good size and very solid; it shows its good breeding by the bluish tints in the veins. Highly recommended as one of the best late Hollander cabbages and we predict that in the future it will be grown more than any other sort. It matures between the Danish Roundhead, Short Stem and the Danish Ballhead, Long Stem. Postpaid, pkt., 15c; 1 oz., 35c; $1 / 1$ lb., $\$ 1.25 ; 1$ lb., $\$ 4.00$.

EARLY WINNIGSTADT (Gold Seal Quality). The old, reliable, well-known, standard cabbage for the market garden. A favorite among growers who have good, rich land. It always meets with ready sales on account of its fine appearance. The heads are pointed, compact, hard, of rich green color and uniform in size, making it a very desirable shipping cabbage. Many growers plant Winnigstadt for their main crop to sell to the shipping trade, who demand a medium-sized, green cabbage that will stand handling. Winnigstadt can be planted closer in the rows than other types, for its growth is upward to a point instead of spreading and round. If planted close on good ground a heavy yield is assured, for Winnigstadt never fails to make a head. Postpaid, pkt.. 10c; 1 oz., 30c; $1 / 4$ lb., 90c; 1 lb., $\$ 2.50$.

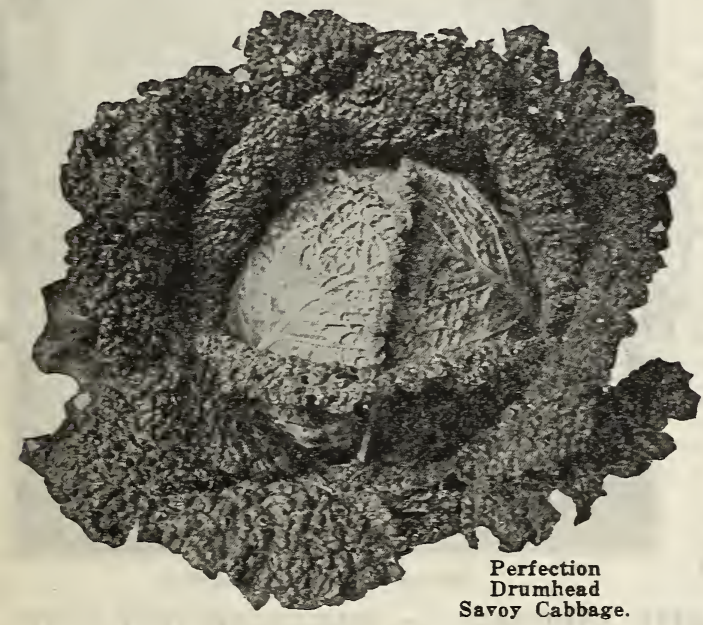

\section{Chinese Cabbage, Pe-Tsai}

A new vegetable that is becoming very popular wherever tried. Market gardeners who have planted it have found ready sales and are now growing and cultivating larger patches of Chinese Cabbage each year. This new vegetable is of the cabbage type and the seed can be planted in the open and thinned out, leaving the plants 15 to 18 inches apart. When nearly full grown the outer leaves should be gathered about the head and tied at the top; in the same manner as you would tie cauliflower. This allows the head to bleach and become tender. When preparing for the table it should be boiled the same as cabbage or used as cold slaw.

PEKING. This is the genuine Pe-Tsai, and most desirable sort for American markets and culture. Postpaid, pkt., $10 \mathrm{c} ; 1$ oz., $40 \mathrm{c} ; 1 / 4 \mathrm{lb}, \$ 1.25 ; 1 \mathrm{lb} ., \$ 4.00$.

\section{Cabbage and Cabbage Seed}

Cabbage is one of our specialties. We are the largest shippers of Cabbage in Colorado, also the largest dealers in Cabbage seed, so of course, we are anxious that you produce a good crop. We supply the quality of seed that will produce such a crop. To realize the best prices from your Cabbage crop, keep the plants free from lice and worms; use same insecticides for Cabbage as for cauliflower. (See page 11).

Cabbage Seed is extremely scarce this season and we will endearor to take care of our trade and supply seed as long as our stock lasts. We suggest you order early. lb., $\$ 3.00$.

The hardest heading and best all-around Savoy. solid head blanches beautifully. Fine flavor. Postpaid, pkt., 10c;

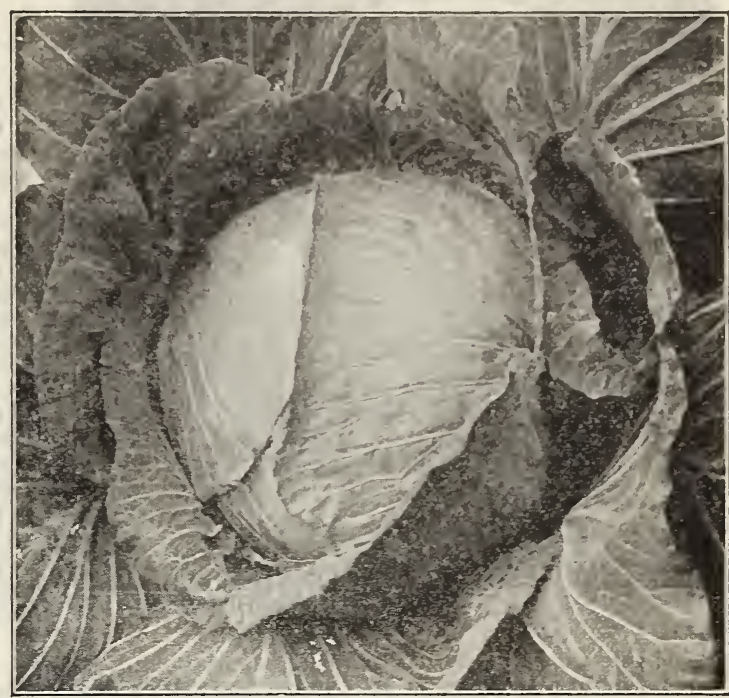

Glory of Enkhuizen Cabbage.

\section{Red Cabbage}

EARLY RED ROCK. This is an improvement over the old Red good sized heads. Color runs even throuph and more solid, with

RED is a late maturing variety, ver Heads are round, of dark bluish red color Round Head green cabbage and is an excellent variety for storage

\section{Savoy Cabbage}

Potpaid, the earliest of

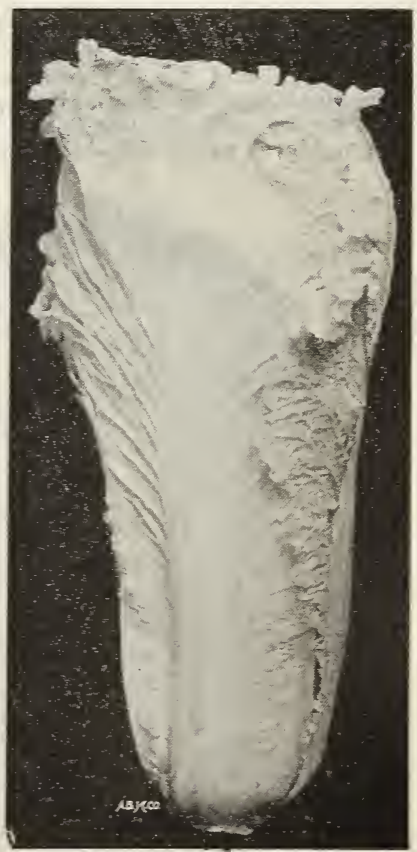

Chinese Cabbage, Peking. (Genuine Pe-Trai). 


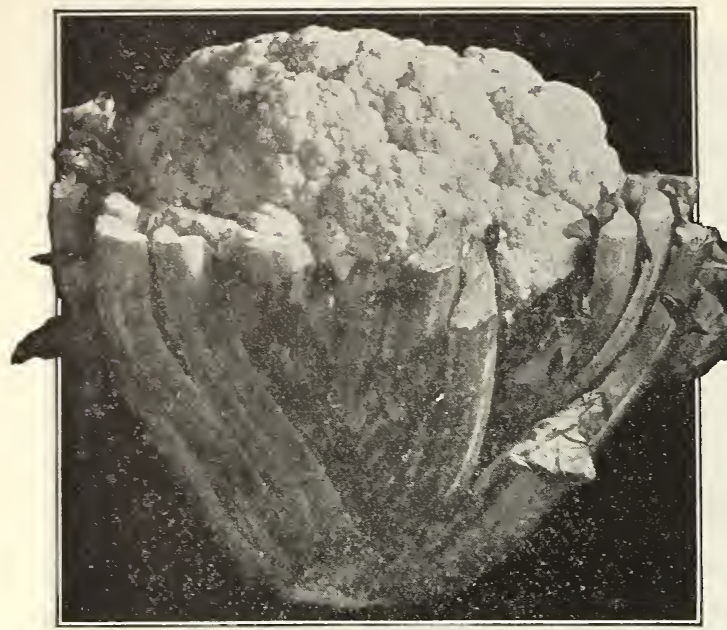

Mountain Snowball.

\section{Cauliflower}

We are the largest dealers in Cauliflower Seed in the West. Prices given below are postpaid.

CULTURE. For early crops, sow seed in hotbeds during February. They should be gradually hardened off before setting out in the field, which should be about the first of May.

For midseason crops, plant seed in cold frames. For late crops plant in open ground and after plants are 4 to 6 inches high, transplant to field.

Cauliflower is grown much in the same manner as cabbage. To make the best, largest and whitest heads the plants need cool moist weather, well enriched soil and thorough cultivation.

After the heads begin to form, the leaves should be drawn up around them and tied at the ends, thus preventing the light getting to the heads and bleaching the cauliflower a snowy white.

Caution! The roots of cauliflower must at no time be allowed to beconie dry either in the plant bed or in the field as it causes the plants to produce what is known as a button or irregular, imperfect, discolored head.

LNSECTS AND WORMS. Don't fail to destroy the worms and bugs that appear on cauliflower. This is very easily done by dusting the plants with Slug Shot, or better, a mixture of 50 lbs. Dehydrated Lime, 1 pint of Nicotine Sulphate and $1 / 2 \mathrm{lb}$. Paris Green, thoroughly mixed and dried.

Cauliflower, like Lettuce and Peas, is being grown to perfection in our mountains, for it does best in a rather cool climate, and each year an increasing number of cars will be shipped.

\section{Cauliflower Plants}

While we grow cauliflower plants to sell, yet, we advise anyoue who anticipates growing cauliflower to raise their own plants. Experience has proven that plants started in the locality in which the cauliflower is to be grown do far better than. plants shipped in. It is cheaper to grow your own plants. It is not necessary that you have glass. Muslin covers are just as good.

We are large handlers of cauliflower and would like to hear from growers who are anticipating putting in crops in the mountains.

EARLY COPENHAGEN SNOWBALL. It is the earliest cauliflower and the one cauliflower that is absolutely certain to head when conditions are ordinarily favorable. It is of very dwarf and compact growth, with large, beautiful and snow-white heads.

This variety is especially recommended where it is desired to grow for the early market when prices are high. Our supply of this variety is limited and we recommend growers placing their orders early. Pkt., 25c; 1/1 oz., 75c: oz., \$2.25; 1/1 lb., \$7.00; 1 lb., \$28.00.

EARLY MOUNTAIN SNOWBALL. This variety is one of the leading sorts for mountain main crop. The heads are pure white, compact, thick and heavy; foliage is dark green, heavily ribbed. A most desirable sort for shipping, as a field of this is very uniform in size and the flower is slow to rice. Pkt., 25c; $1 / 2$ oz., 75 c; 1 oz., $\$ 2.50$; $1 / 4$ lb., $\$ 9.00 ; 1$ lb., $\$ 28.00$.

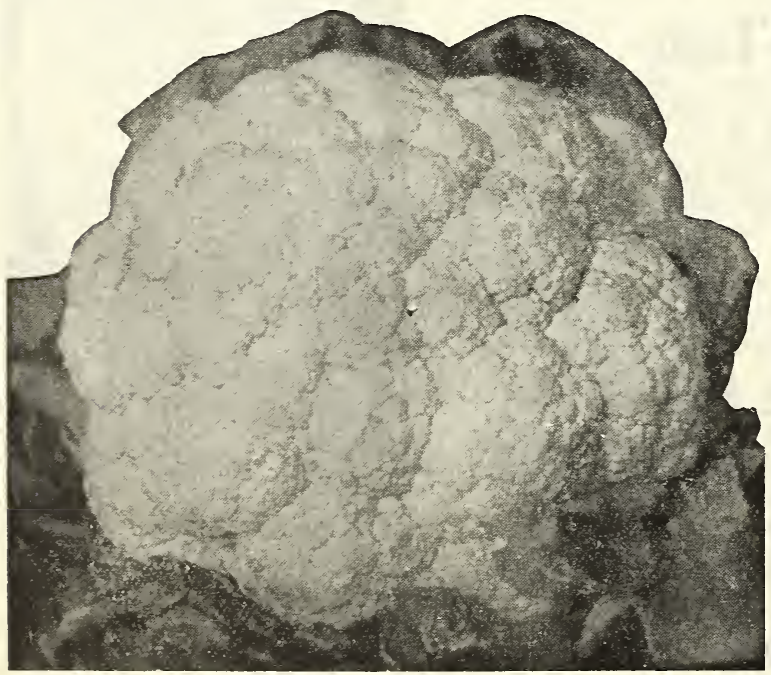

MAXINE SNOWBALL or SELF-PROTECTING SNOWBALL. This strain of cauliflower was so highly recommended to us by the largest cauliflower seed growers of Europe that we secured samples and tested it out. To our surprise we found it to be one of the best grades of cauliflower ever grown in our vicinity. It is sarly and a heavy yielder of even-sized and very firm heads. The foliage is very dense and overlaps the tender flower, thus protecting it from the hot sun and making it an almost sure crop. This strain we highly recommend to growers of cauliflower. It is a sure cropper. Pkt., 25c; $1 / 4$ oz., 90c; oz., $\$ 2.50 ; 1 / 4 \mathrm{lb}$., $\$ 9.00 ; 1 \mathrm{lb}$., $\$ 30.00$, postpaid.

\section{(New) Extra Early Mountain Snowball}

A Cauliflower of Exceptional Merits and Quality

During the seasons of 1928 and 1929 we gave this strain widespread trials with very satisfactory results. We find this variety most resistant to adverse weather conditions and it is much earlier than any of the other main varieties, in fact, it is the only Extra Early Cauliflower suited for Mountain growing. The heads are exceptionally deep and high and covered with plenty of dark foliage. We recommend this variety to Mountain Growers for their early crop. Pkt., 35c; $1 / 2$ oz., $\$ 1.75 ; 1 \mathrm{oz}_{\text {, } \$ 3.00 ; 1 / 4} \mathrm{lb}$., (New) Extra Early Mountain Snowball. $\$ 11.00 ; 1 \mathrm{lb}$., $\$ 40.00$, postpaid. 


\section{Cauliflower}

DANISH PERFECTION (Gold Seal Quality). Is a very fine and improved variety of the Dwarf Erfurt type. While this cauliflower has only been on the market a short while, yet, year in and year out for midseason crop we recommend it as the most profitable and satisfactory cauliflower to plant, because it is surer to head in hot weather; produces a compact white head of very attractive appearance which is well protected with large, erect outside leaves. It is very uniform in maturing and to use the words of the originator, the entire crop can be harvested at one time for cutting. This variety is especially recommended for dry season. Pkt., 25c; $1 / 4$ oz., 70c; 1 oz. \$2.00: $1 / 4$ lb., $\$ 7.50 ; 1$ lb., $\$ 27.00$, postpaid.

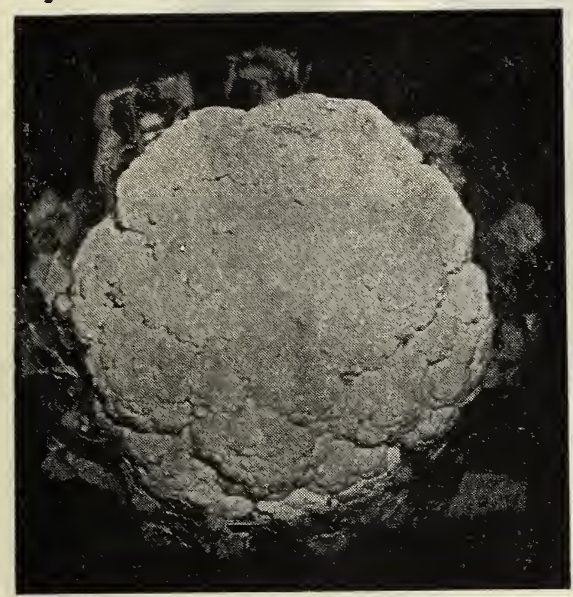

Johnson's Special Strain Snowball.

JOHNSON'S SPECIAL STRAIN OF SNOWBALL. We have placed this strain of Cauliflower in competition with the finest and highest-priced seed sold by all the best dealers in this country and Europe, and have found nothing to equal it in certainty of crop and perfect white heads. It has won the approval of the critical gardeners, being the most reliable sort grown. It is not only suitable for early use, but it is superfine for late planting. The heads are hard and solid and do not spread as do some of the inferior sorts. No other equals it in purity of color being clear snow-white. Pkt., 25c; 1/4 oz., 90 ; 1 oz., $\$ 2.50 ; 1 / 4$ lb., $\$ 9.00 ; 1$ lb., $\$ 30.00$ postpaid.

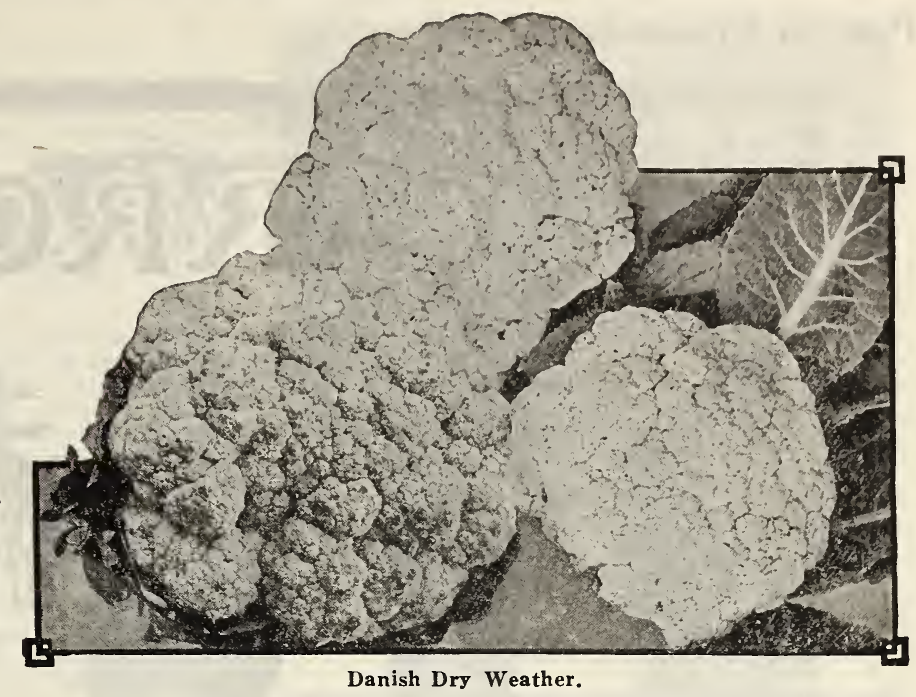

EARLY DWARF ERFURT. For the very early market we recommend this variety; it grows on a short stem; produces solid white heads. As you will note the price of this Cauliflower is very reasonable ayd planters should not hesitate in using this variety because of this reason. Especially recommended for mountain growing. Price, postpaid: Pkt., 15c; $1 / 4$ oz., 65c; 1 oz., \$1.75; $1 / 4$ lb., $\$ 6.50 ; 1$ lb., $\$ 22.50$.

DANISH DRY WEATHER. A very large second early variety, producing immense compact heads, with remarkable heat-resisting qualities. Does well when grown for a fall crop. Prices, pkt., 25c; $1 / 40 z ., 75 c ; 10 z$., $\$ 2.00$; $1 / 4$ lb., $\$ 7.50 ; 1$ lb., $\$ 25.00$, postpaid.

EARLY PARIS. A hardy variety quite easy to grow and forming good heads. Pkt., 10c; 1/4 oz., 35c; oz., $90 \mathrm{c}$, postpaid.

HARTNER'S SPECIAL SNOWBALL. Not as early but for main crop in districts that have an altitude of 6000 feet or less, it should be planted for the main crop where it produces the finest crop of cauliflower. Heads deep balloon-shaped, snow-white, solid, very regular, which are protected with plenty of dark green foliage. We have seen nothing to equal it in quality or sureness of crop. Price, Pkt., 25c; $1 / 4$ oz., 90c; oz., $\$ 2.50 ; 1 / 4 \mathrm{lb}$., $\$ 9.00$; 1 lb., \$30.00, postpaid.

Extra Selected. Pkt., 35c; $1 / 2$ oz., $\$ 1.75 ;$ oz., $\$ 3.00 ; 1 / 4$ lb., $\$ 11.00 ; 1 \mathrm{lb}$, $\$ 40.00$, postpaid.

Cauliflower, like Cabbage, is one of our specialties. It is the fourth largest crop produced in Colorado and with good seed and a reasonable amount of care, Colorado and New Mexico growers are providing the very best quality of Caulifiower. But like Cabbage, Cauliflower must be kept free from worms and aphis. This is easily done if sou apply poison early.

The following is a very effective and cheap poison: 50 lbs. Dehydrated Lime Ib. Paris Green

1 pint of Nicotine Sulphate

Mix thoroughly. Dust over plants with one of our dusters (pages 92-93), or a can with small holes in the bottom will often answer the purpose. The ingredients can be obtained from us ready for mixing.

\section{Amount of Vegetable Seeds Sown to the Acre.}

\begin{tabular}{|c|c|c|c|}
\hline & Qua & & Quantity Per AC \\
\hline 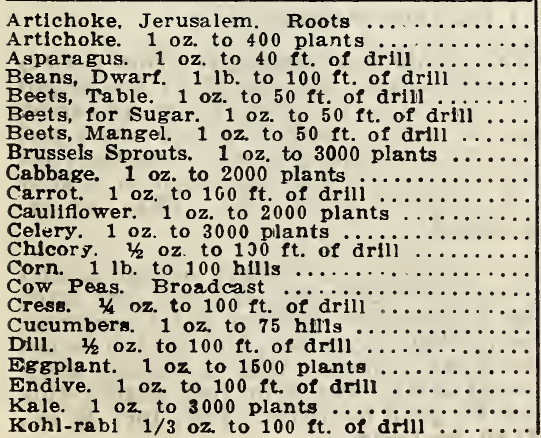 & 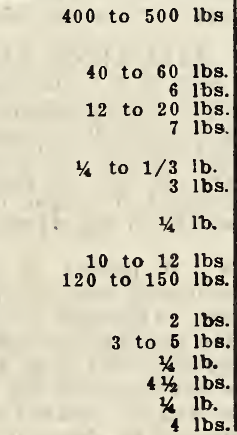 & 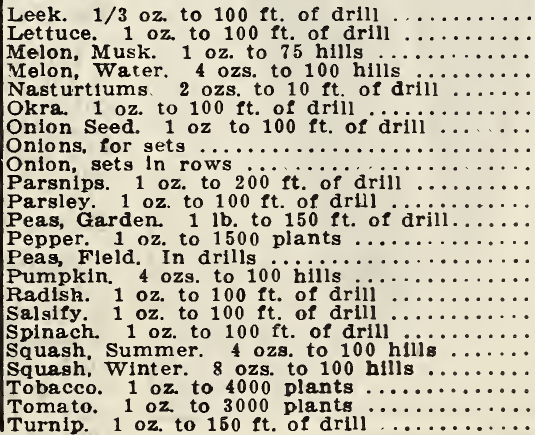 & 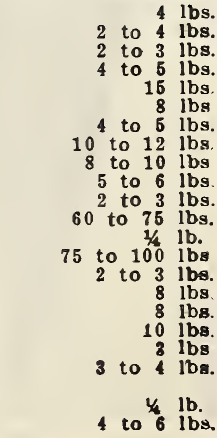 \\
\hline
\end{tabular}


(1)
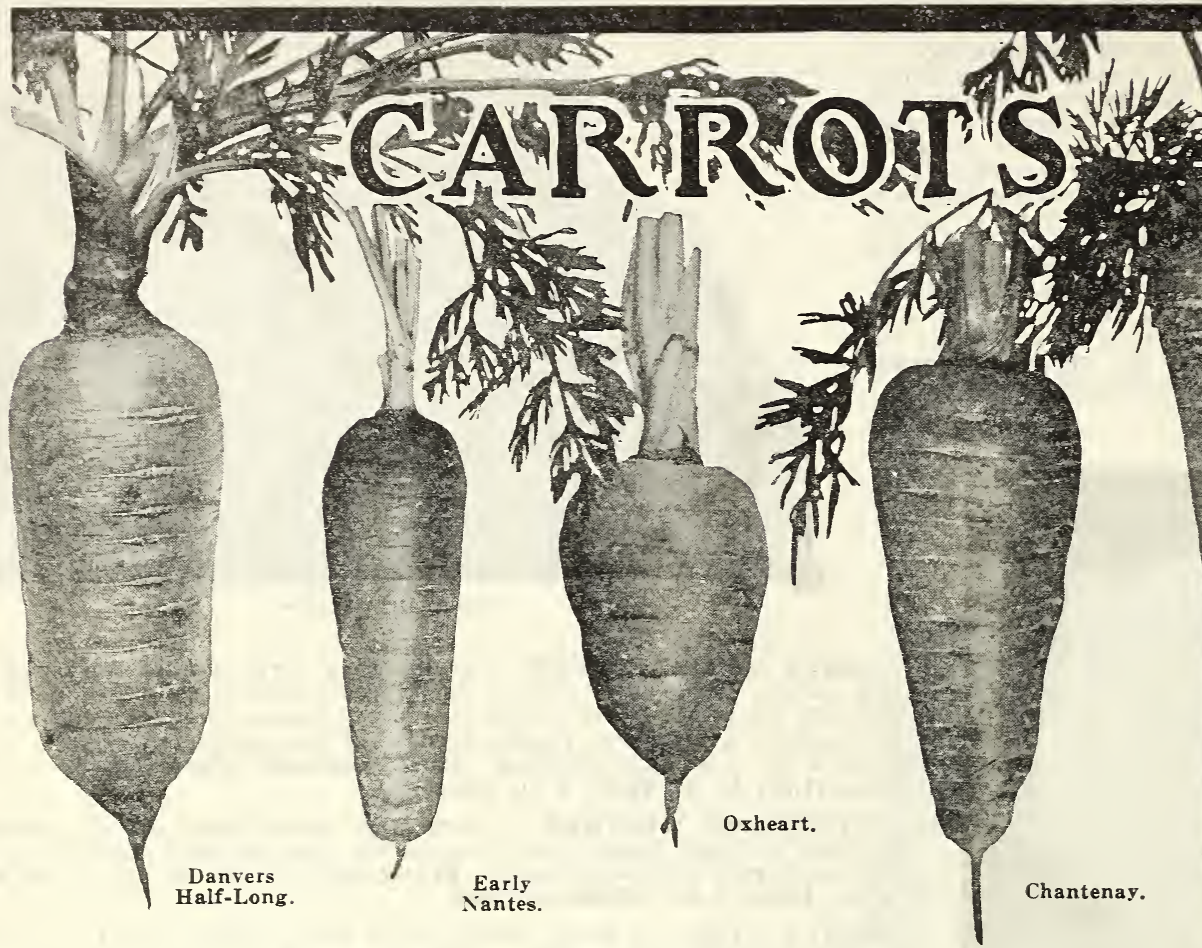

\section{Our Carrot Seeds are all Selected French Grown and Can Be Depended Upon as They Have Been Tested.}

CULTURE. The Carrot will do well in any good, well worked soil. For early use sow the seed when the ground is fit to work, in rows 15 inches apart, and when 2 inches high, thin out so that the plants stand 2 inches apart in the row. For fall and winter use, sow the seed from the 1st to the 15th of June. The roots may be stored in cellar or pit, covered

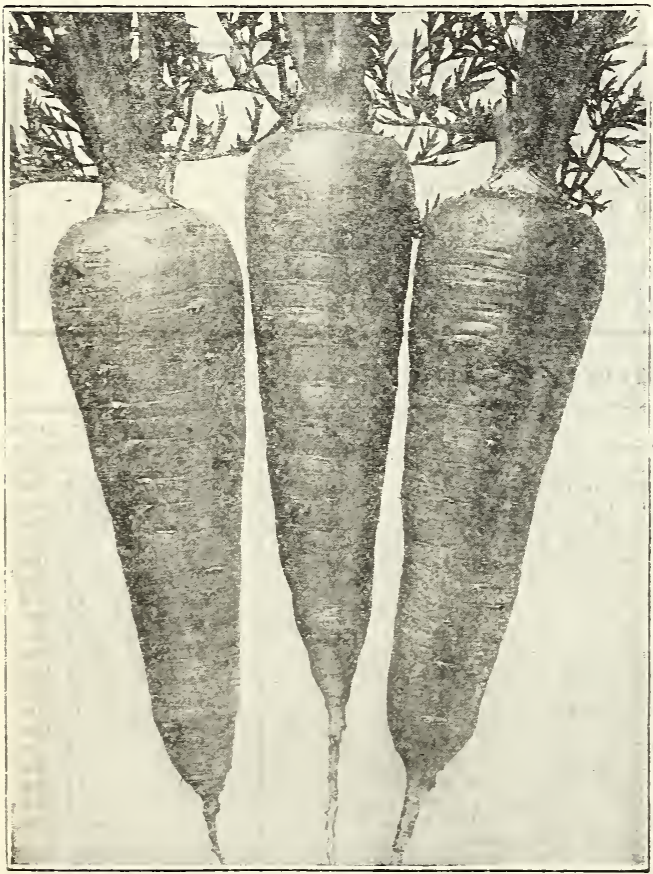

Early Half-Long Nantes. with dirt, where they will keep solid until late in the Spring.

CHANTENAY (Gold Seal Quality). We consider this the standard Carrot, for when young it is about equal to the Nantes for bunching. and later when they increase in size are the best for sacking or for washing and to be sold in bushels. The Carrots grow about 6 inches long, fine grained, sweet, and sugary. It is not as long as the HalfLong Danvers, and is more stump rooted and not apt to crack open while growing. An excellent table variety and heavy cropper. Our seed is most carefully selected. Pkt., 5c; oz., 15c; 1/4 lb., 35c; 1 lb., $\$ 1.00$, postpaid.

DANVERS HALF-LONG (Gold Seal Quality). The most popular variety with nine-tenths of the market gardeners in this vicinity. It will produce more than any other kind, and cannot be equalled as an all around Carrot. Very suitable for bunching for summer sales, and on the other hand, being an excellent keeper, it may be stored in pits, when the tops are cut, and sold during the Winter. It is rich orange in color and a bumper cropper-much favored for stock feeding. Grows 5 to 7 inches long, 2 to $2 \frac{1}{2}$ inches wide at the top. Pkt., 5c; oz., 15c; $1 / 4$ lb., 35c; 1 lb., $\$ 1.00$, postpaid.

EARLY HALF-LONG NANTES (Gold Seal Quality). This variety is the earliest of the standard sorts and on account of its fine bright color is planted very extensively in this section for a bunching carrot, presenting a very fine appearance when bunched. It is sweet and fine flavored, almost without a core, very fine grained. Excellent for home garden, as well as for the market. One of the finest in quality and handsomest in shape of the medium sized sorts. Pkt, 5c; oz. $15 \mathrm{c} ; 1 / 4 \mathrm{lb}, 35 \mathrm{c} ; 1 \mathrm{lb}$., $\$ 1.00$, postpaid.

FEONIA. A carrot of great promise, its bright orange-scarlet color, its splendid size, shape, and productiveness all being very much in its favor. Although a cross between the Nantes and Chantenay, it resembles the Hutchinson more than any other, but the top is not quite so green. We feel that it will quickly take a leading place among the sorts grown for bushel sales. Try it in your garden this year. You will be pleased with its good qualities. Pkt., 10c; 1/2 oz... $10 \mathrm{c}$; oz., $20 \mathrm{c}$; $1 / 4 \mathrm{lb}$., $55 \mathrm{c}$; lb., $\$ 1.50$, postpaid. 


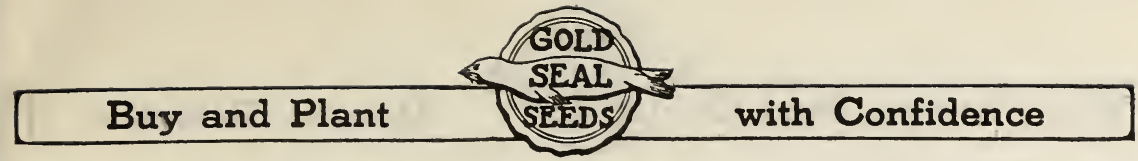

\section{CARROTS-Continued}

EXTRA EARLY SCARLET HORN. This variety should not be planted for the main crop. Its growing should be confined to the extra early marketing when as yet there are none of the standard varieties offered. Pkt., 5c; oz, 15c; $1 / 4$ lb., 35c; 1 lb., $\$ 1.00$, postpaid.

OXHEART or GUERANDE. The most popular and heaviest cropper among the short carrots. The shape is very desirable for heavy soils. The true type is about $4 \frac{1}{2}$ inches long and 3 inches thick at the shoulder, tapering slightly to the bottom, and is very stump rooted. Pkt, 5c; oz., 10c; $1 / 4 \mathrm{lb}, 30 \mathrm{c} ; 1 \mathrm{lb}$, $\$ 1.00$, postpaid.

CORELESS ORANGE (New). This is a half-long, perfect carrot, blunt pointed with small tap-root and small top. They run uniform in size and shape, 6 to 7 inches long by $1 \frac{1}{2}$ inches through, clear skinned, easily pulled, and keep well. The flesh is fine in texture, sweet and mild flavored, entirely devoid of stringiness, coarseness or wood-heart or core. Color of flesh is rich red-orange. Excels other half-long carrots in earlines without being inferior in productiveness. Pkt., 10c; oz., 20c; $1 / 4 \mathrm{lb}$., 50c; 1 lb., \$1.50, postpaid.

\section{CARROTS FOR STOCK FEEDING}

Attention-Don't Fail to Plant at Least a Few Carrots for Your Stock

Carrots make a healthy and desirable food for horses, and every horse owner should plant them liberally, so as to give his horses an occasional feed of carrots through the winter. They are also very desirable for feeding to hogs and cattle and make a tonic and alterative food which is of decided benefit. Plant in March, April or May-the earlier the better-at the rate of 3 to 4 pounds per acre. Cultivate same as mangel beets.

MASTODON CARROT. This abundant yielder is strictly a stock carrot and grows to be of enormous size. Now, if you want a good winter feed for your stock don't overlook this new wonder, for it is just what your horses and other stock need. There is no use to tell you what carrots do for stock, for everybody knows that 8 horse or a cow likes carrots. But, speaking of carrots, this extra large, massive, heavy producer is what you want to plant for a stock carrot. Plant 2 pounds to the acre of this seed. Pkt., 5c; oz., 10c; 1/4 lb., 25c; 1 lb., 90c, postpaid.

IMPROVED LONG ORANGE. This variety should not be planted for market use, although it has a good color and the same flavor as the Danvers, but owing to its long, tapering growth it does not sell well for table use. It is grown extensively for stock feeding. Pkt., 5c; oz, 10c; 1/4 lb., 25c; 1 lb., $75 \mathrm{c}$, postpaid.

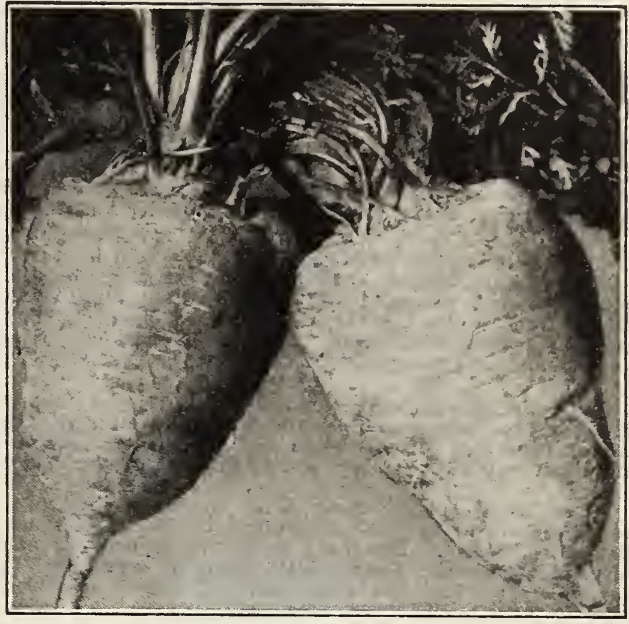

Oxheart Carrots.

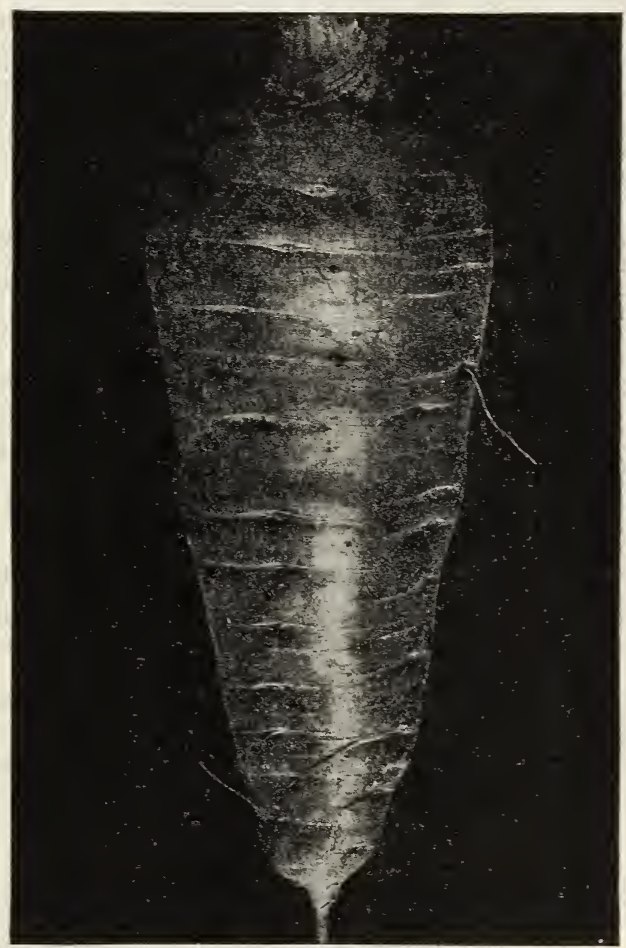

Chantenay Carrot.

GIANT WHITE BELGIAN. Roots grow one-third above ground, are white below and green above ground; small tops; flesh somewhat coarse, roots large size, and are extensively grown for stock feeding. Pkt., 5c; oz., 10c; $1 / 4 \mathrm{lb} ., 25 \mathrm{c} ; 1 \mathrm{lb}$., $75 \mathrm{c}$, postpaid.

GIANT YELLOW BELGIAN. They do not produce as large roots as the White Belgian; the flesh is less coarse. It grows about 11 inches in length and 3 to $3 \frac{1}{2}$ inches in diameter at the crown. Gives a large yield and is very easy to harvest. Pkt., 5c; oz., 10c; 1/4 lb., 25c; 1 lb., 75c, postpaid.

\section{SOUP COLLECTION}

SPECLAL PRICE, 25 CENTS, POSTPAID

1 Pkt. Carrots

1 Pkt. Celery
1 Pkt. Cabbage

1 Pkt. Peas

Regular Price, 45c
1 Pkt. Turnips

1 Pkt. Onions 


\section{Celery}

\section{Celery}

\section{Our Celery Seed is Tested and Guaranteed Pure}

Celery is one of the main vegetable crops of Colorado. Next to Cabbage and Lettuce it is the largest crop of vegetables produced in Colorado. While there are many varieties of Celery, only a few sorts prove profitable, namely : Golder

CULTURE FOR SUMMER CELERY. Seed is started in hotbeds the middle of March and requires close attention, keeping the seed bed moist and giving plenty of air. Plants should be set out any time between the 1st and 20 th of plenty of air. results are obtained from double rows, that is, set plants on each May. Best resigating ditch. Set plants from 6 to 8 inches apart in the rows, side of the irrigating ditch. Set plan
and double rows 3 to $31 / 2$ feet apart.

Self-Blanching Celery requires close attention and plenty of cultivation, as it is very injurious to the crop if the plants are allowed to stunt, which is of water, but water should not be allowed to stand in the rows.

After the Celery is about ready to harvest it can either be bleached with par, boards or by banking with dirt. The former method is used when early paper, baas of Celery is dithe summer large fields usually bleach with paper or with bleach without boards or banking.

If grower desires to keep Celery later than October 20th, it should be confined to trenches for protection against the cold.

CULTURE FOR WINTER CELERY. Seed should be sown as late as April 15 th and planting outdoors can be done any time from June 1st to July 25 th. This variety of Celery requires artificial bleaching, either by wrapping each stalk are with paper or by trenching. The former method is only used when early pascal Celery is desired, but for flavor, quality, and long keeping, when early pascal Celery is the stalks have been stored in trenches some time, trenching is necessary. After the stalks have been stored in trenches some time, the hearts make considerable growth and it is

HARTNER'S GLANT PASCAL. This Pascal is an improved and highly developed strain of Giant Pascal. It is much larger than the regular Pascal and free from soft much larger than the regular Pascal and in appearance and form are perfect, and its eating qualities are better than any celery ever offered for the table. It is free from strings, crisp, and sweet, and does not get soft. For the market gardener and winter Celery growers there is none better. Its earliness and size make it the most profitable of all Celery. By early, we mean that it grows to an enormous size and grows quick so that it can be wrapped in paper and bleached above ground weeks before frost. It can be harvested from the field at the high prices that prevail for early Pascal Celery. Thousands of dozens of Celery are sold this way and the grower does away with trenching; or else, it can be allowed to grow still larger and just before cold weather can be stored for the Winter in trenches, keeping perfectly until Spring. When taken out it will be bleached and possesses the rich, nutty flavor that is making it the favorite Pascal.

Strain A (Short Stalks). Pkt., 20c; 1/2 oz., 50c; oz., 75c; $1 / 4$ lb., $\$ 2.25$; lb., $\$ 7.00$.

Strain B (Tall Stalks). Pkt., 20c; $1 / 2$ oz., 60c; oz., 80c; $1 / 4$ lb., $\$ 2.60$; lb., $\$ 10.00$.

GOLDEN SELF-BLANCHING (Old French Strain)-(Gold Seal Quality). This is the regular Golden Self-Blanching, that has been grown with success for many years from California to New York, from Washington to Florida. While the new variety of Golden Self-Blanching will, no doubt be planted to a greater extent than ever before, yet we feel that all growers who plant for shipping will do well to plant at least a part of their field to this old variety, because it holds up better after being cut, and for storing we recommend this strain. Pkt., 10c; $1 / 2$ oz., 60c; oz., $\$ 1.00$; $1 / 4$ lb., $\$ 3.00$; lb., $\$ 8.00$.

GOLDEN SELF-BLANCHING (New French Strain). This is the variety that has been grown so extensively in this district for the past four years. This strain grows 8 to 10 inches taller than the old strain. The rib stalks are broader and it does not contain as many heart stalks as the old strain, but it is a very vigorous and healthy grower. Pkt., $15 \mathrm{c}$; $1 / 2$ oz., 70c; oz., $\$ 1.00$; $1 / 4$ lb., $\$ 3.50$; lb., \$12.00.

MAMMOTH GOLDEN SELF-BLANCHING. New. This variety is an improvement on the French strains, being equally as tall as the New French Strain, but has more heart stalks, a robust grower, seed is of high vitality. We consider it the leading Summer variety. We have given this new seed a thorough trial and find it very satisfactory. We believe that as soon as it is once tried, growers will plant no other Summer variety. Pkt., $10 c$; oz., 80c; 1/4 lb., \$2.75; lb., $\$ 10.00$.

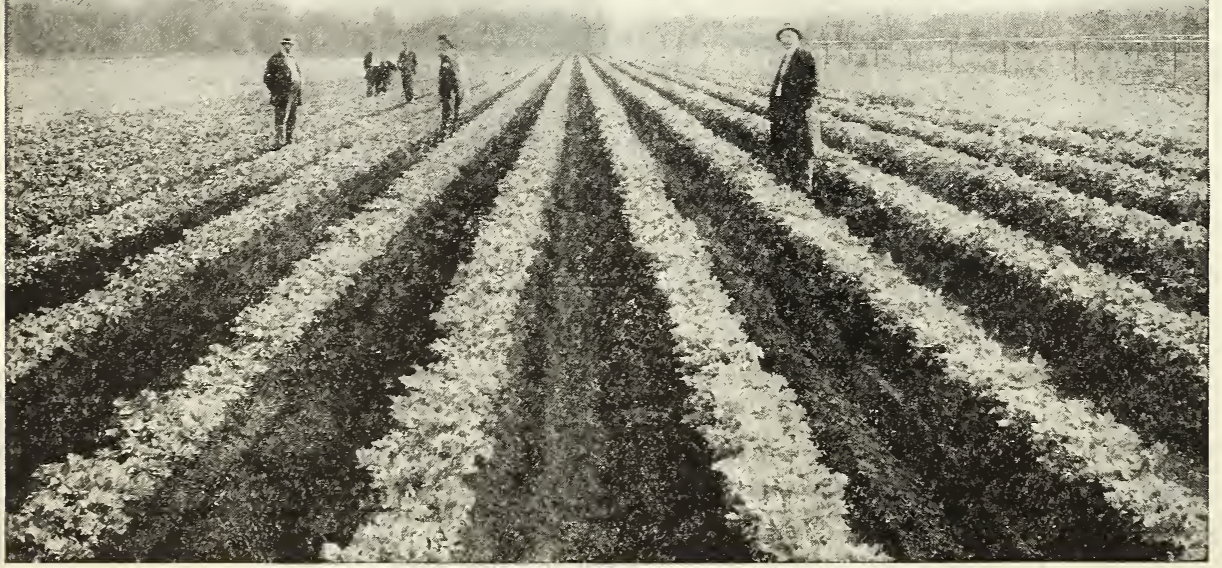

Celery is the Third Largest Crop of Vegetables in Colorado.

\section{CELERY PAPER}

In the large celery growing districts of Florida and California they no longer use boards for bleaching their celery, but a special made paper is used, which is cheaper and more economical than boards, quicker and cheaper to put on, and lasts just as long. Price, roll, 12 inches wide, 310 feet long, $\$ 2.25$, not prepaid. 


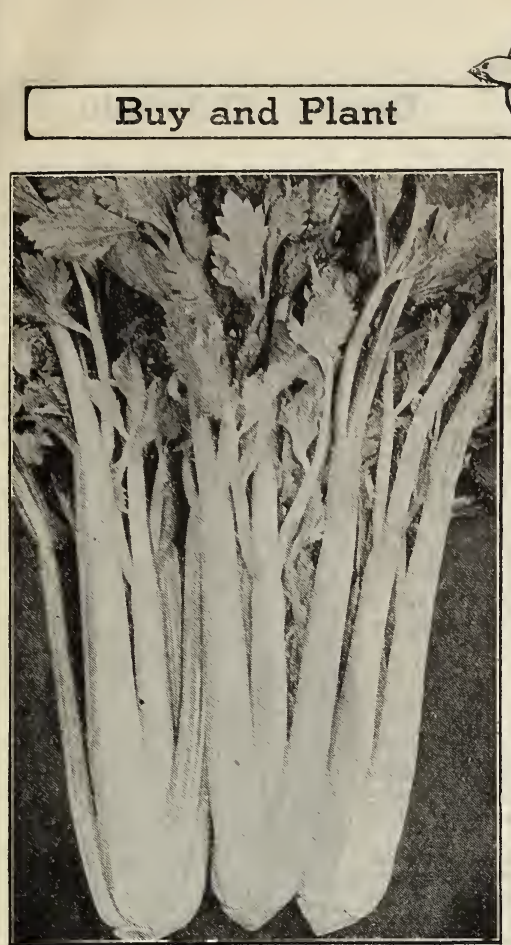

Hartner's Giant Pascal.

\section{CELERY-Continued}

COUNTRY CLUB or SALT LAKE CELERY. Celery grown in the Salt Lake District has built up a wonderful reputation. Many authorities consider it superior to the Pascal. The stems or stalks are thick and meaty, producing very sturdy plants with a large heart, however the outer stalks are just as palatable. From experience we find this celery is not adapted to trenching but should be bleached by wrapping with paper or banking with dirt. Pkt., 25c; 0z, $\$ 1.00 ; 1 / 4 \mathbf{l b}$. $\$ 2.25 ; 1 / 2$ lb., $\$ 4.00$; lb., $\$ 8.00$, postpaid.

GOLDEN SUMMER. This is a cross between the Easy Bleaching and Golden Self-Blanching. It has the hearty robust habits of the Easy Bleaching and the color of the Golden Self-Blanching. We believe it will prove very valuable and will eventually take the place of the Golden Self-Blanching, as soon as its qualities are known. Pkt., 20c; 1/2 oz., $\$ 1.00 ;$ oz., $\$ 1.50 ; 1 b ., \$ 20.00$.

SELECTED WHITE PLUME Almost self-bleaching. Its stalks and portions of the inner leaves and heart are nearly white. Early, of good flavor and fine texture; adapted to fall and early winter use; a good keeper up to the holiday season. Pkt., 10c; $1 / 2$ oz., 20c; $1 / 4$ lb., 80c; lb., $\$ 2.50$, postpaid.

GIANT PASCAL (French). By many, Giant Pascal is considered the sweetest and best flavored Celery grown and on account of its fine keeping qualities it is one of the best Winter varieties. The plants are usually started in cold frames and planted in the open during the month of June, and as late as July 10th. To enable the grower to market this variety earlier than November 1st, ordinary newspaper is used to wrap about the stalk while growing in the field, and left so until the stalk, which was originally dark green, becomes whitened. Although Pascal, when treated in this manner, brings a very good price, it does not acquire as sweet a flavor as when trenched. This strain of seed is French-grown and of very good quality; however, planters who grow for the market prefer Hartner's Giant Pascal, which is listed here. Pkt., 10c: oz., 30c; $1 / 4$ lb., 80c; lb., $\$ 2.50$, postpaid.

\section{Chicory}

WITLOOF, or FRENCH ENDIVE. Is used principally as a winter salad, and it is most delicious served with French dressing. The seed should be sown in the open ground not later than June, in drills 12 to 18 inches apart and the seedlings should be thinned out to stand not closer than 3 inches. The plants form long, parsnip-shaped roots which are lifted in the Fall, trimmed of leaves and stored in a cool place until wanted for forcing. The roots should be planted upright about $11 / 2$ to 2 inches apart in a trench 16 to 18 inches deep. The roots when grown as above produce leaves which are delicious as a winter salad. Pkt., 10c; oz., 30c; $1 / 4$ lb., 90c, postpaid.

IMPROVED LARGE LEAVED. As the name indicates, the leaves of this sort are larger than the common kinds. This is a very superior variety. Pkt., 5c; oz., 20c; $1 / 4$ lb., 50c; lb., $\$ 1.50$, postpaid.

LARGE ROOTED. The roots are cut in thick slices, roasted and used instead of coffee. Leaves in the Spring are also used for salads. Pkt., 5c; oz., 20c; $1 / 4$ lb., 50c; lb., \$1.50, postpaid.

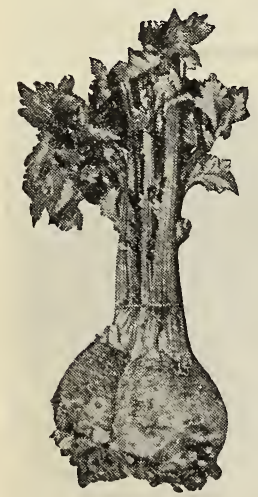

Celeriac.

\section{Celeriac \\ or Turnip Rooted Celery}

Grown for the roots, which are large, turnip-shaped; tops very small. Although the consumption is limited, due to the fact that its eating qualities are so little known, for a salad it excels all other varieties of Celery, having a fine flavor. It can also be stewed or used for flavoring. It may be stored like beets and will keep all Winter. Pkt., 5c; oz., 20c; $1 / 4$ lb., 70c; lb., $\$ 2.25$, postpaid

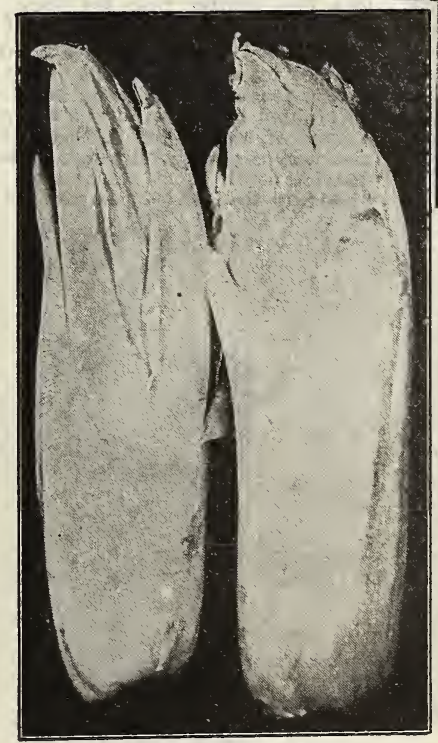

Witloof Chicory.

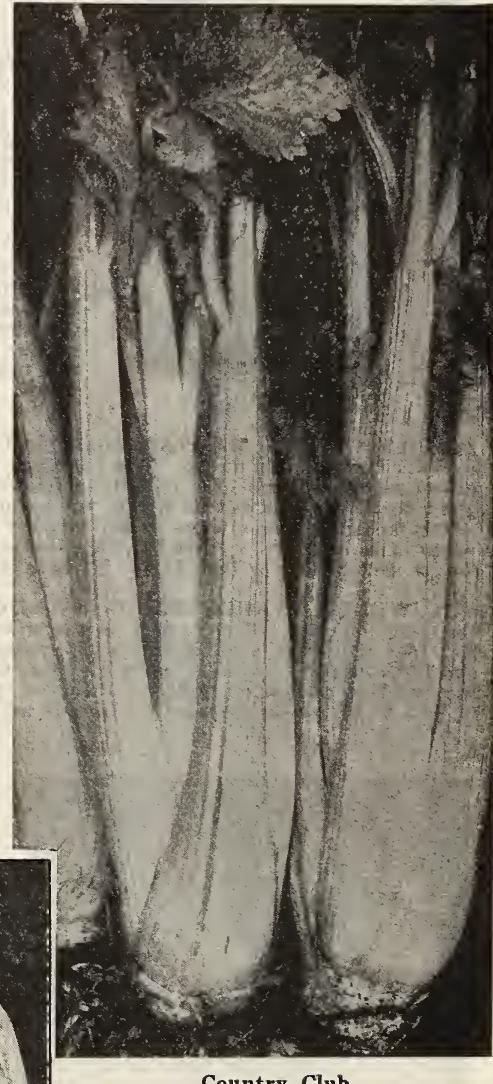

Country Club.

\section{Chervil}

A hardy plant which resembles double curled parsley and is used for flavoring and garnishing. Pkt., 5c; oz, 10c; $1 / 4$ lb., 30c; lb., \$1.00, postpaid.

\section{Chives}

An onion-like plant, used in salads and for flavoring soups. The plant also makes an excellent ornamental garden bed edging, which may frequently be cut, a new growth of leaves appearing soon after each cutting. One sowing will answer for about 3 years. Pkt., 5c; $1 / 4$ oz., 25c; oz., 75c, postpaid. (Chives Plants-See page 42) 


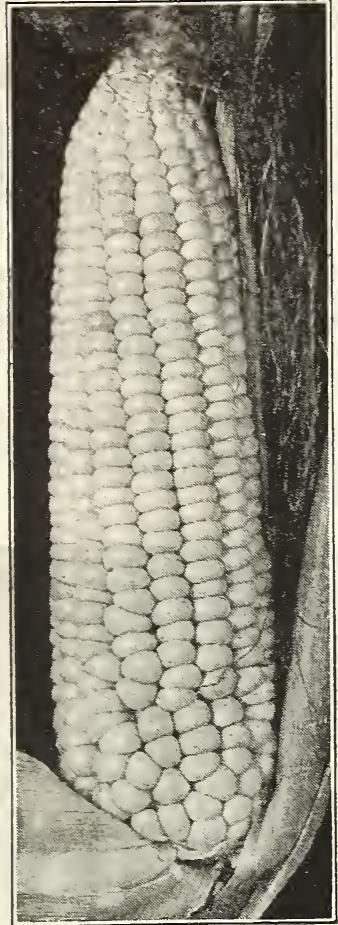

Hartner's Pearl.

\section{Sweet Corn}

Our Prices are Postpaid Up To and Including Ten Pounds You Should Plant Western Grown Seeds

CULTURE. A rich, warm sandy soil is the best, but excellent sweet corn can be raised on any good, ordinary soil if it is deeply and thoroughly worked before planting. In the West sweet corn should be planted as early as can be done without risking great loss from frosts or from rotting of the seed in the soil. If planted in rows, make the rows about 4 feet apart and place the seed 14 to 16 inches apart in the row, covering 1 inch deep with fine soil firmly pressed down. If planted in hills, make the hills for the early varieties 3 feet apart each way and plant 6 kernels to the hill. For the later sorts the hills should be not less than 4 feet apart each way. Hoe frequently, and when 6 inches high thin so as to leave 3 or 4 plants in the hill. Give frequent and thorough but shallow cultivation until the tassels appear.

\section{Hartner's Pearl}

The Earliest $S$ weet Corn in Cultivation

There is no other vegetable that is awaited with so much eagerness as the first Sweet Corn, but the great disadvantage with our first roasting ears is, they are either of very small size or they are not of

HARTNER'S PEARL is an extremely early variety of corn that has been thoroughly acclimated to our climate and will continue to grow throughout the early cold spring days when other varieties usually bethroughout the early cold spring days when other varieties usually be come stunted. Several experiments on diferent soils the past season variety the Early Pearl to be from

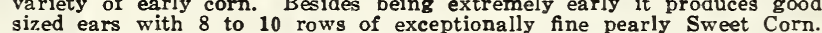
sized ears with 8 to 10 rows of exceptionally fine pearly Sweet Corn. It is superior to all other varieties of early corn for it withstands light
frost and can be planted early in the Spring and will, from the day of germination, rush forward to meet the early demand for sweet green corn. It is a fine early corn for the garden and a money maker for $\$ 1.35 ; 10$ lbs., $\$ 2.50$. If by freight or express at purchaser's expense, $5 c$ per lb. less.

EARLY GOLDEN BANTAM (Gold Seal Quality). Is the sweetest, richest, and most tender sweet corn grown. One of the finest. The ears are from 6 to 7 inches long, eight rowed, filled with broad, sweet, golden yellow kernels of a delightful fiavor. It may be planted from 10 days to 2 weeks earlier than most sweet corns, as it is not as apt to rot as many of the softer kinds. It is as early as the Cory and of much sweet corns, as it is not as apt to rot as many of the solter kinis. It is as early as the Cory and of much better flavor. It in ay "Golden Bantam" a trial. Prepaid, pkt., 5c; large pkt., 10c; i l lb., 15c; 1 lb. lovers of sweet corn to give "Golden Bantam" a trial. Prepaid, pkt., 5c; large pkt., 10c; $1 / 2 \mathrm{lb}$.,
$25 \mathrm{c} ; 5 \mathrm{lbs} ., \$ 1.00 ; 10 \mathrm{lbs}$., $\$ 1.85$. If by express or freight at purchaser's expense, 5c per lb. less.

STOWELL'S EVERGREEN (Gold Seal Quality). This is the corn with the long, deep kernels; the kind you enjoy eating. This variety is the most widely known and best advertised of all late sweet corns, and therefore there is more Stowell's Evergreen planted for late crop than all other late varieties together. The large ears of 18 to 20 rows of long, deep, juicy, tender kernels makes it such a favorite. It produces an abundant amount of fodder. Postpaid, pkt., 5c; large size pkt., $10 \mathrm{c} ; 1 / 2 \mathrm{lb}$., $15 \mathrm{c} ; 1 \mathrm{lb}$., $25 \mathrm{c} ; 5 \mathrm{lbs}$., $\$ 1.00$. 10 lbs., \$1.85. If by express or freight at purchaser's expense, 5c per lb. less.

EARLY MAYFLOWER (Gold Seal Quality). In the Mayflower

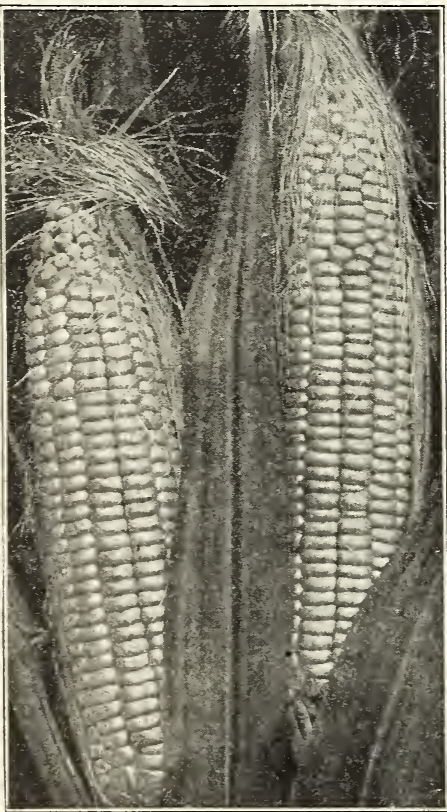
we offer you one of the earliest sweet corns, being ten days earlier than the Early White Cory. The ears are very much larger than the Cory having Cory. The ears are very much larger than the cory, having ten and twelve rows in quality will be found far superior in spite of its extreme earliness. The stalks are six inches to a foot shorter than the Cory, Prices, pkt., $5 \mathrm{c}$; large pkt., 10c; $1 / 2 \mathrm{lb} ., 15 \mathrm{c} ; 1 \mathrm{lb} ., 25 \mathrm{c} ; 5 \mathrm{lbs}$., $\$ 1.15 ; 10 \mathrm{lbs} ., \$ 1.85$, postpaid. If by express or freight at purchaser's expense, $5 \mathrm{c}$ per lb. less.

EARLY DENVER SWEET CORN. This is an exceptionally early Sweet Corn. In fact, it is claimed by sume to be the earliest Sweet Corn. It grows on a very short stalk, quite often producing two ears to a stalk, and four to six ears to the hill. Because of the compact growth it can be planted close together for heavy yield. Mr. Fred Bunger, the introducer of this corn, claims a yield of 100 bushels to the acre can be expected under favorable circumstances. This variety is also very desirable for stock feeders on account of heavy yield of ensilage fodder with grains. For districts with short seasons, we especially recommend Early Denver. Price, 1 lb., 35c; 5 lbs., $\$ 1.60 ; 10 \mathrm{lbs} ., \$ 3.00$, postpaid. 50 lbs. or more, $25 \mathrm{c}$ per $\mathrm{lb}$., not postpaid.

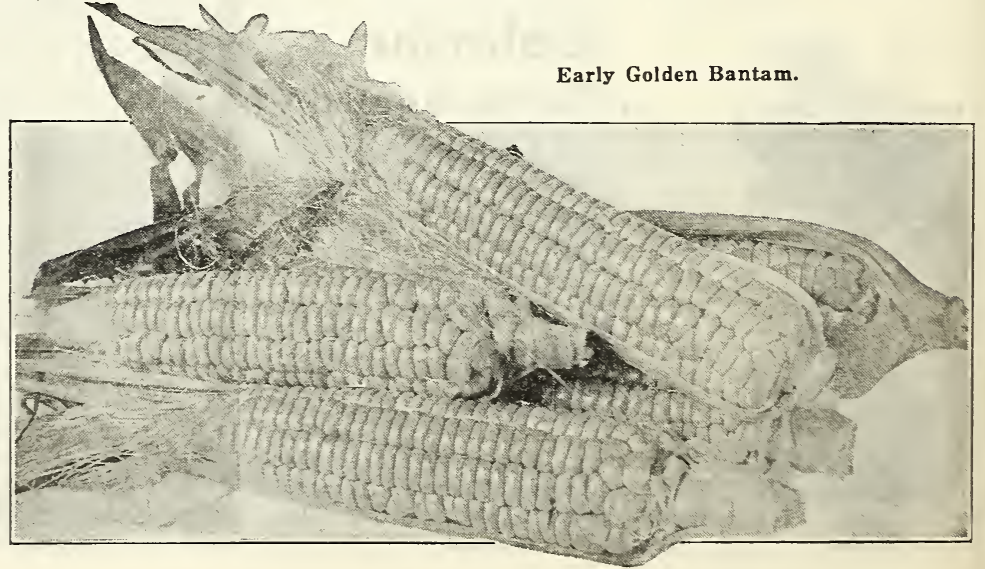




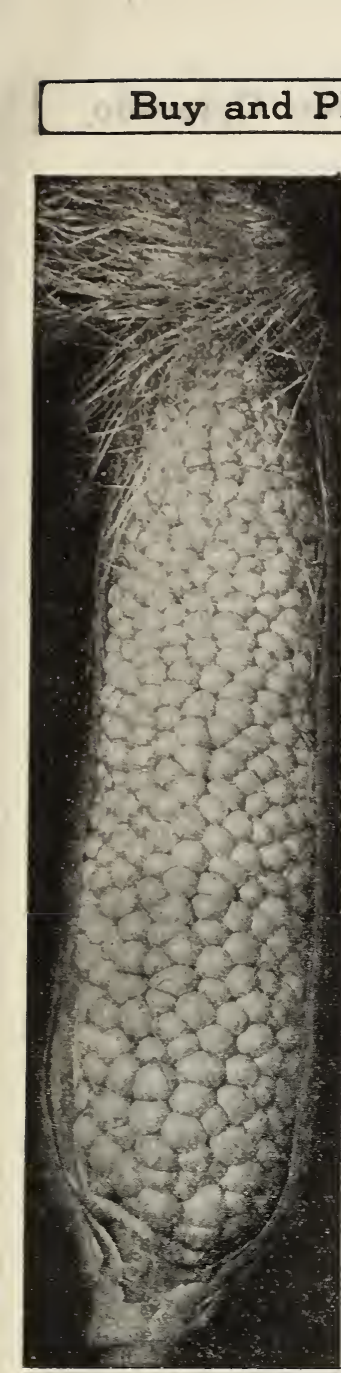

Country Gentleman.

\section{SWEET CORN-Continued}

COUNTRY GENTLEMAN or SHOE-PEG. The sweetest and by many regarded as the most delicious of all sweet corn. A very productive sort, bearing several a pure white kernels. A late variety. Postpaid, pkt., 5c: large size pkt., 10c; $1 / 2 \mathrm{lb}$., 15c; $1 \mathrm{lb} ., 25 \mathrm{c} ; 5 \mathrm{lbs} ., \$ 1.15 ; 10 \mathrm{lbs}, \$ 2.00$. If by express or freight at purchaser's expense, $5 c$ per lb. less.

GOLDEN EVERGREEN or LARGE BANTAM SWEET CORN. Leading market gardeners of the East have endorsed the Golden Evergreen as the best selling and most profitable yellow corn to grow. Few years ago we placed samples among corn growers near Denver, and they report very favorably as to its eating and selling qualities, stating that it is not extra early but follows the extra early and should be termed a "Second Early." Postpaid, pkt., 5c; 2 ozs., $10 \mathrm{c}$; lb., 30c; 5 lbs., $\$ 1.25 ; 10$ lbs., $\$ 2.00$

GOLDEN SUNSHINE. The earliest of the Golden Bantam type, maturing a Gel to ten days with ears $61 / 2$ inches long, containing 12 rows of broad, yellow, sweet grains. Pkt.. 10c; 1/2 lb., 20c; 1 lb., 35c; 10 lbs., $\$ 2.50$, postpaid.

EXTRA EARLY ADAMS. This variety is not grown for its eating qualities (as it is not very sweet) but is planted for the early market, as the higher prices that are paid for the first roasting pkt., 5c; large size package, $10 \mathrm{c} ; 1 / 2 \mathrm{lb} ., 15 \mathrm{c} ; 1 \mathrm{lb.,} 25 \mathrm{c} ; 5$ lbs., $90 \mathrm{c}$; 10 lbs., pkt., 5c; large size package, $10 \mathrm{c} ; 1 / 2 \mathrm{lb}, 15 \mathrm{c} ; 1 \mathrm{lb}, 25 \mathrm{c} ; 5$ lbs., $90 \mathrm{c}$
$\$ 1.60$. If by express or freight at purchaser's expense, $5 \mathrm{c}$ per lb. less.

DE LUE'S GOLDEN GIANT. It is very similar to the Golden Bantam, however, not quite as deep golden in color, nor quite so good in quality but ears are larger and a little later Pl $5 \mathrm{c}$; 5 lbs., $\$ 1.00 ; 10$ lbs., $\$ 1.85$. If by express or freight at purchaser's expense, 5c per lb. less.

EARLY MINNESOTA. An old favorite early sweet corn. Good sort for the market and home garden. Stalks about $5 \frac{11 / 2}{2}$ feet high, bearing 1 or 2 long eight-rowed ears. Grains very broad, sweet and tender. Postpaid, pkt., 5c; large size pkt., 10c; $1 / 2 \mathrm{lb} ., 15 \mathrm{c} ; 1 \mathrm{lb}, 25 \mathrm{c} ; 5$ lbs., $\$ 1.00 ; 10 \mathrm{lbs}, \$ 1.85$. If by express or freight at purchaser's expense, $5 \mathrm{c}$ per lb. less.

PEEP O' DAY. A very early small-eared variety of western origin. The stalks grow 3 feet high, are well leaved and average two fine ears to the stalk. Ears are small, about 6 inches long, well filled from butt to tip, having 10 rows of small grains, which are very sweet. Postpaid, pkt., 5c; large size pkt., 10c; $1 / 2 \mathrm{lb}$., $15 \mathrm{c} ; 1 \mathrm{lb} ., 25 \mathrm{c} ; 5 \mathrm{lbs}, \$ 1.00$; $10 \mathrm{lbs} ., \$ 1.85$. If by express or freight at purchaser's expense, $5 c$ per lib. less.

HOWLING MOB (Special Strain). Our special strain of Howling Mob seed corn has won the favor of our best market gardeners. It has been bred to produce corn ready for the market 6 to 8 days earlier than our best market gardeners. It has been bred to produce corn ready the old strains. The stalks are strong and vigorous, producing
2 to 3 extra large ears to each stalk, and we have counted as many as 18 to 20 rows of pearly, tender grains to the ear.

This corn is not only a very profitable corn for the market gardener but is also a favorite for the home gardens. Postpaid, pkt., $5 \mathrm{c}$; large size pkt., 10c $1 / 2$ lb., 15c; 1 lb., 25 c; 5 lbs., $\$ 1.00 ; 10$ lbs., $\$ 1.85$. If by express or freight at purchaser's expense 5 c per lb. less.

EARLY EVERGREEN (Gold Seal Quality). The ears of this fine corn are 10 inches long, being mostly 14 to 18 rows; a magnificent kind for market gardeners and for main crop in the home garden. It ripens 10 to 12 days in advance of Stowell's Evergreen and remains green long time. Two plantings will extend until frost, but the ears are not quite as large as Stowell's. Postpaid, pkt., 5c; $1 / 2$ lb., 15c; 1 lb., 25c; 5 lbs., $\$ 1.00 ; 10$ lbs., $\$ 1.85$. If by express or freight at purchaser's expense, $5 c$ per lb. less.

BLACK MEXICAN. This corn when in condition for the table cooks remarkably white, but the ripe grain is black or bluish black. It is unsurpassed in tenderness and fine quality. Very desirable for family use. Postpaid, pkt., 5c; large size pkt., $10 \mathrm{c}$; $1 / 2 \mathrm{lb}$., $15 \mathrm{c}$; $1 \mathrm{lb} ., 25 \mathrm{c} ; 5 \mathrm{lbs}$. $\$ 1.00 ; 10$ lbs., $\$ 1.85$. If by express or freight at purchaser's expense, $5 c$ per lb. less.

WHITE COB CORY. The main variety of corn for early planting, being one of the first of the sweet varieties. The stalks are usually from 4 to $41 / 2$ feet high, each bearing 2 or 3 ears that have 8 rows. Postpaid, pkt., 5c: large size pkt., 10c; $1 / 2$ lb., 15c; 1 lb., 25c; 5 lbs., $\$ 1.00$;

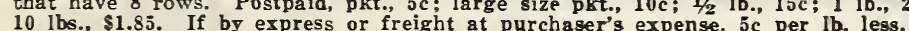

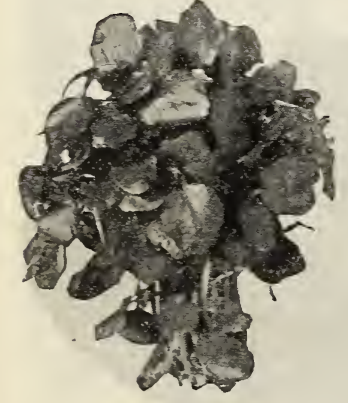

Water Cress.

\section{CORN SALAD}

A most refreshing salad. Hardy, much used during Winter in stead of lettuce. May be sown either in the Spring or Fall. Pkt., 5c; oz., 20c; $1 / 4$ lb., 60c.

\section{CRESS}

GARDEN CRESS or PEPPER GRASS. Much used with lettuce, to which flavor it adds an agreeable pungency. Pkt., 5c; 0z., 20c; $1 / 4$ lb., 60c.

TRUE WATER. The pleasant, peculiar flavor of water cress makes it one of the most delicate salads for table use. It will grow where there is a supply of good fresh water. Pkt., 5c; oz., $60 \mathrm{c}$; $1 / 4 \mathrm{lb}$., $\$ 2.25$.

POPCORN, SEE PAGE 83

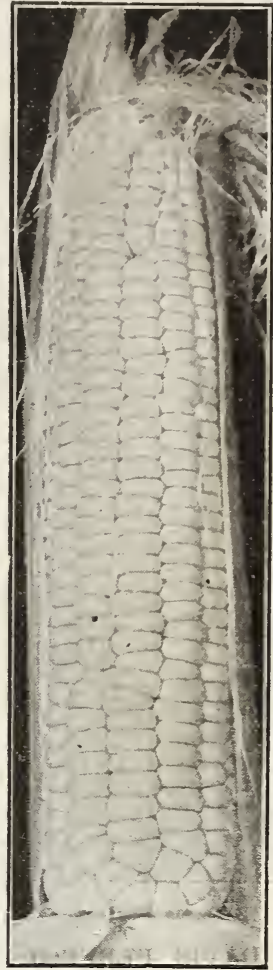

Early Mayflower.

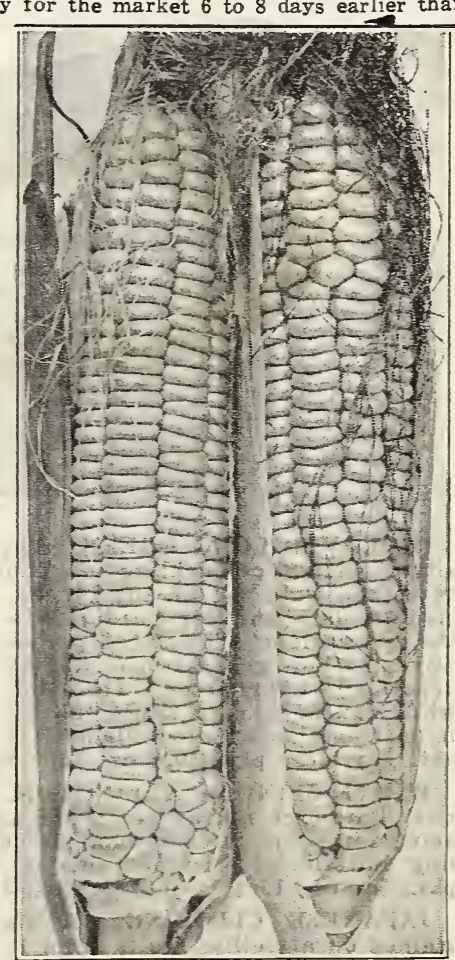

Golden Sunshine. 


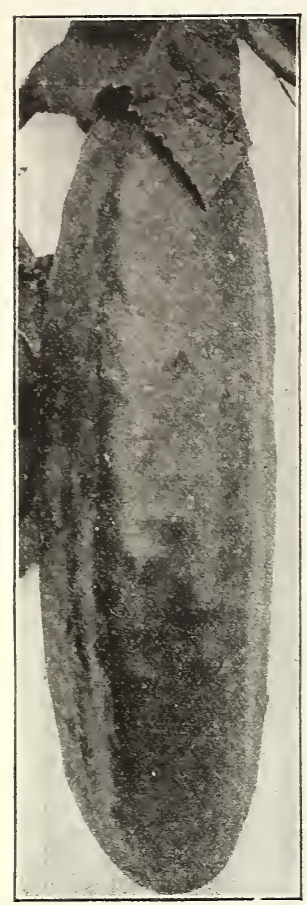

Davis Perfect.

DAVIS PERFECT. This is the popular cucumber so greatly used by all market gardeners, being productive, dark green in color, and grows 8 to 14 inches in length. having few seeds, and remains green a long time. A good keeper. Postpaid, pkt, 5c; oz, 15c; 1/4 lb, 40c; lb, \$1.25. variety for size, color, and keeping qualities. Postpaid, pkt., 10c; oz., 15c; 1/2 lb., $90 \mathrm{c} ; 1 \mathrm{~b}, \$ 1.50$.

WESTERN GLASS. This is a cucumber we have recently bred up, especially for hothouse cultivation; al though many growers who tried it use it also for outside planting. It is extra long, 18 to 20 inches. Is unusually dark green, firm, and straight. Pkt, 15c; oz, $35 \mathrm{c}$; $1 / 4$ lb., 90c; $1 / 2$ lb, $\$ 1.75$.

\section{Cucumbers}

(Prices on Cucumbers Postpaid)

Our Cucumber Seeds are all Colorado grown, and will produce heavy crops-besides being dealers in Seeds, we are Colorado's largest shippers of Vegetables.

CULTURE. As soon as the weather has become settled and warm, plant in hills 4 to 6 feet apart each way, with 8 to 10 seeds in a hill. Cover one-half an inch deep, smoothing the hill off with the hoe. When the plants are out of danger of insects, thin out to 3 or 4 plants to a hill. Cultivate and hoe often until the plants begin to make runners or vines.

IMPERIAL CUCUMBERS. Another strictly Western Grown "Gold Seal" product that has attained the highest favor among the most critical cucumber growers in the country, and has taken the place of such valuable varieties as the Davis Perfect, Fordhook Famous, Long Green, White Spine, etc., among the market gardeners, because it is more prolific, of better color and more uniform in size, averaging from 10 to 14 inches in length. They are always straight and free from crippled or little necks, withstands blight better and has practically no seed chamber, but it is composed of almost solid white firm flesh that is most delicious in flavor. We especially recommend it to growers for outdoor planting, as a shipping cucumber. It excels any other

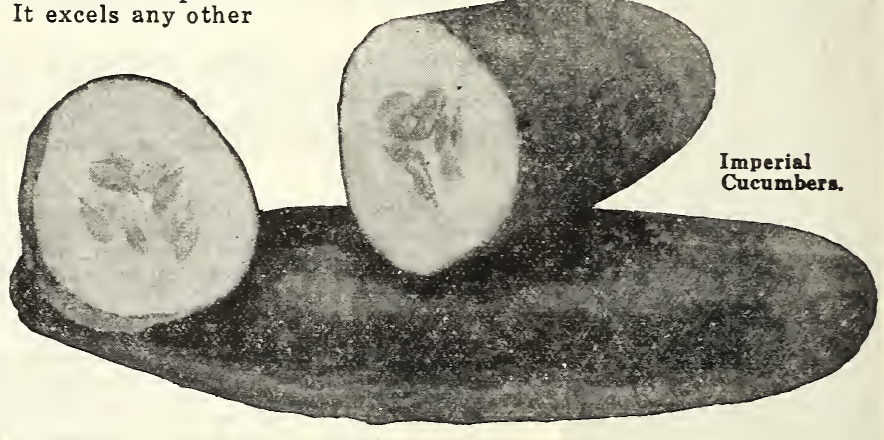

KLONDIKE. This sort is a leader in many of the eastern markets for early or late crop. Fruits are of the improved White Spine shape, although they do not show as much white at the tips as the White Spine. They are long, of a deep green color, very productive and extremely early. Postpaid, pkt., 5c; oz., 10c; 1/4 lb., 35c; lb., \$1.25.

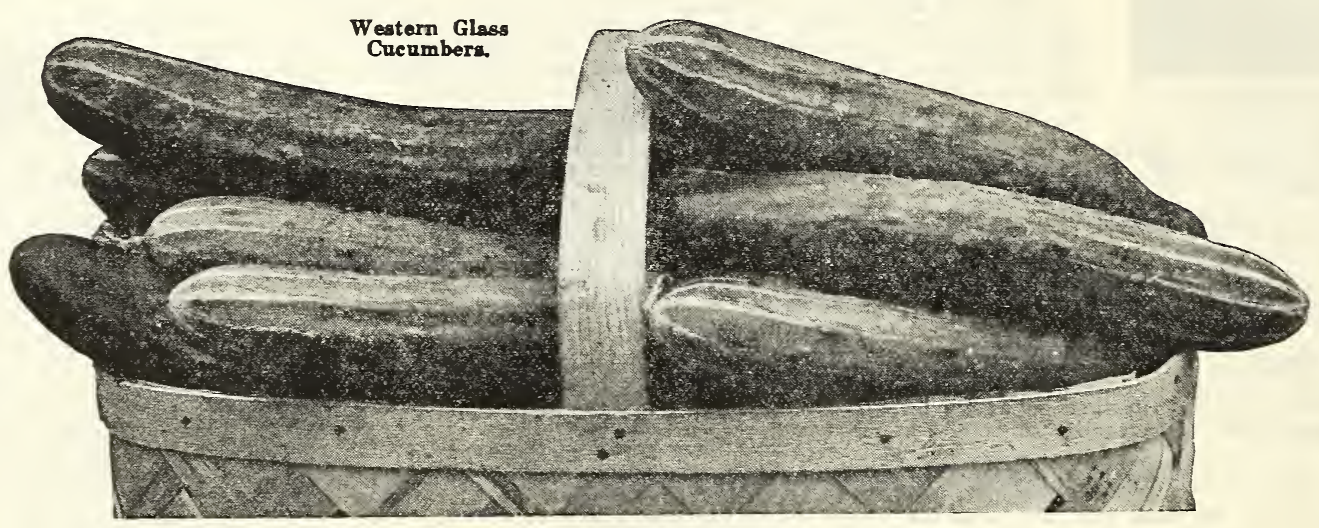

IMPROVED LONG GREEN. The standard cucumber for either slicing or pickling, the Long Green enjoys about twice the wide use of any other. It is extremely prolific, medium late and for hardiness and disease-resistance is the best variety. The ends taper somewhat and it is slightly warted. For general use for all purposes there is no superior to Long Green. The small pickles are well shaped, while in the slicing stage the fruits are very attractive. It is sometimes called "London Long Green." Postpaid, pkt., 5c; large pkt., 10c; oz, 15c; 1/1 lb., 40c; lb., \$1.25.

WHITE SPINE or ARLINGTON. A very productive variety, although not as green nor as long as Davis Perfect, being somewhat thicker than the other varieties. For pickling and slicing combined this is our selection. Postpaid, pkt, 5c; oz, $15 \mathrm{c}$; $1 / 4 \mathrm{lb}, 40 \mathrm{c}$; lb., $\$ 1.25$.

JAPANESE CLIMBING. A vigorous grower; can be trained on a trellis; fruits from 12 to 16 inches long, dark green, and smooth; flesh pure white, crisp, and tender. Plst. 5c; oz., 15c; 1/4 lb, 50c; lb., \$1.50, postpaid.

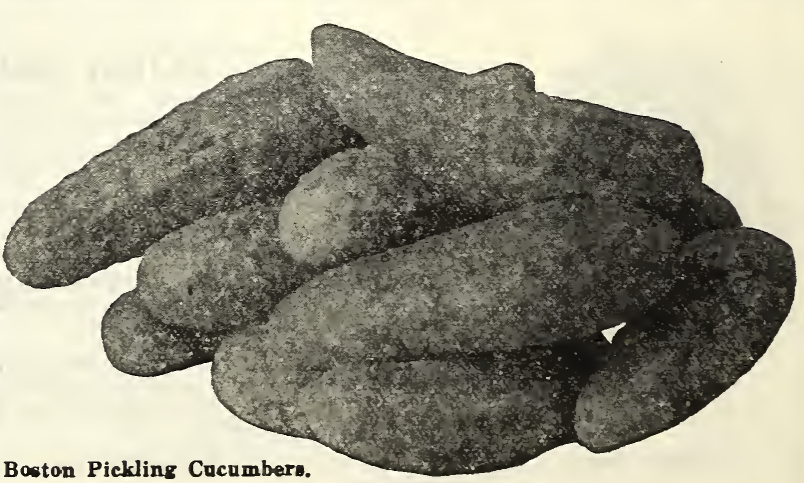




\section{Eggplant}

CULTURE. In February or March, sow in hotbeds and keep warm. When 2 inches high, transplant to pots or to good rich soil, and about the middle of May set out in the open 3 feet apart each way. Eggplant must have deep and thorough cultivation.

BLACK REAUTY (Gold Seal Quality). Ten days to two weeks earlier than the New York Improved. Fruit a little longer in shape and slightly darker. It is entirely free from spines around the corolla. Is of dark, rich, purplish black color. Very attractive. Desirable for either early crop or very late planting. It is a healthy grower and a remarkable yielder. Pkt., 15c; oz., 50c; 1/4 lb., \$1.50; ib., \$5.00.

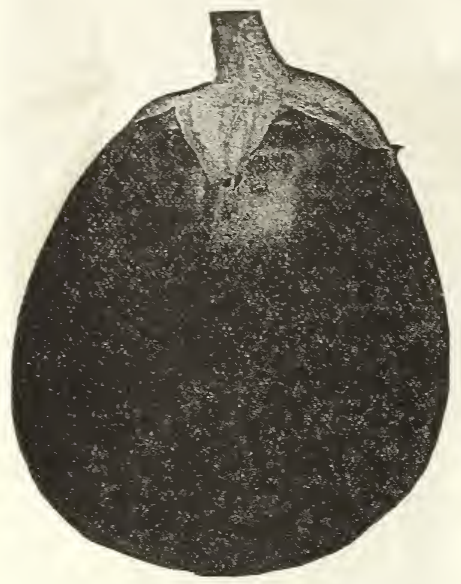

Black Beauty Eggplant.

\section{Kale}

DWARF CURLED SCOTCH. Most popular variety for general use. Leaves much curled and very tender; color bright green. Postpaid, pkt., 5c; large size pkt., $10 \mathrm{c}$; oz., $15 \mathrm{c} ; 1 / 4 \mathrm{lb}, 40 \mathrm{c} ; 1 \mathrm{~b} ., \$ 1.25$.
NEW YORK IMPROVED (Gold Seal Quality). This variety is a general favorite for both market and home gardens. The plant is spineless, large, and spreading, with light green foliage. It usually produces 4 to 6 large, oval fruits of a splendid dark purple color. The vigor and productiveness of the plants and the large size, earliness, and fine quality of its fruits, make it a most profitable variety for Market Gardeners. Pkt., 15c: oz, 50c: 1/4 lb $\$ 1.50$; lb., $\$ 5.00$.

\section{Garlic Sets}

We have a selected lot of good, clean bulbs that will all grow. Those who are fond of this vegetable for flavoring should raise their own supply. $1 / 4 \mathrm{lb}, 20 \mathrm{c}$; lb., 50c, postpaid. For larger amounts get our special price.

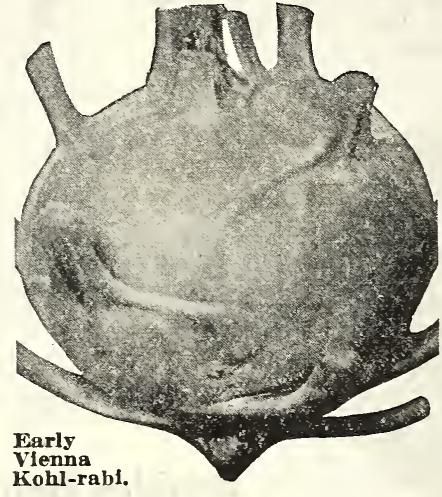

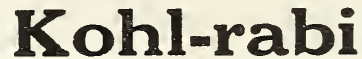

(Easy to Grow)
CULTURE. This vegetable, when young and tender, is fine for table use; when matured keeps splendidly, and is fine for soup flavoring. For early use, sow in hotbeds, transplant, and cultivate like early cabbage. For winter use, sow in rows in the middle of June or first of July, transplanting or thinning to 8 inches apart.

EARLY WHITE VIENNA. Skin light green, fiesh white, leaves smooth and short. Well adapted to forcing. Pkt., 5c; oz., 25c; $1 / 4 \mathrm{lb}$., 60c.

EARLY PURPLE VIENNA. The swollen stem and leaves are of purplish color; flesh attractive light green. Pkt., 5c; oz., 25c; $1 / 4$ lb., $60 \mathrm{c}$.

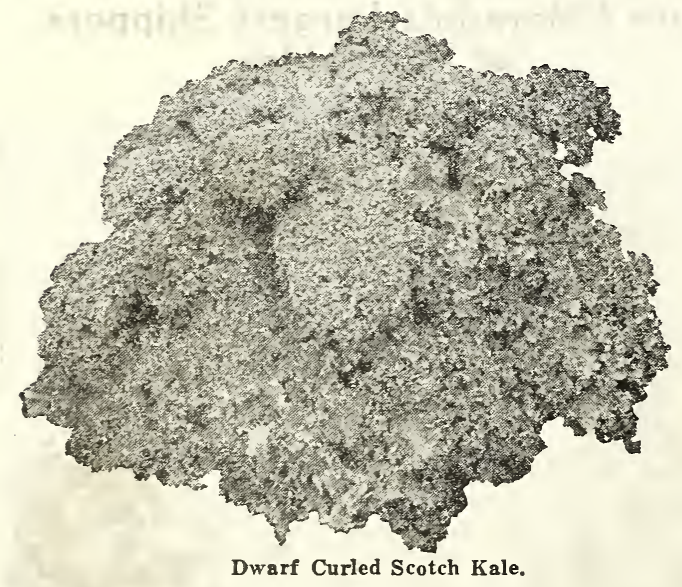

A species of onion which does not form a bulb, but is used for its mild, delicious root stem or neck. Although it is not very well known to the American kitchen, yet wherever it has been tried it has been given a permanent place among the vegetables. It is much sweeter and milder than the onion, being used mostly for flavoring where the onion taste is desired, or it can be boiled the same as boiling onions and served with butter, salt, and pepper. Plant in rows and cultivate the same as onions, except when well grown hill up with earth to get a long white stem.

GIANT CANADIAN. Is the largest species introduced and is very suitable for our district. Prices, postpaid: Pkt, 5c; oz., 25c; 1/4 lb., 75c.

AMERICAN FLAG. A very desirable variety. Prices, postpaid: Pkt., 5c; oz., 15c; 1/4 lb., 50c. ;20]

\section{Garden Huckleberry}

While classed as a fruit, it belongs in the same family as the tomato and eggplant, being grown and cultivated in the same manner. It is an annual and produces fruit from seed the first year; is very easily grown and succeeds in any good soil. The seed frames and set out the same as cabbage and tomatoes and yields great masses of rich fruit all Summer and Fall. The fruit is as large as a grape and jet black when ripe. It is fine Huckleberry and makes delicious pies, jellies, preserves, jams, etc. Pkt., $10 \mathrm{c} ; 1 / 4$ oz., $30 \mathrm{c}$.

\section{Leek}

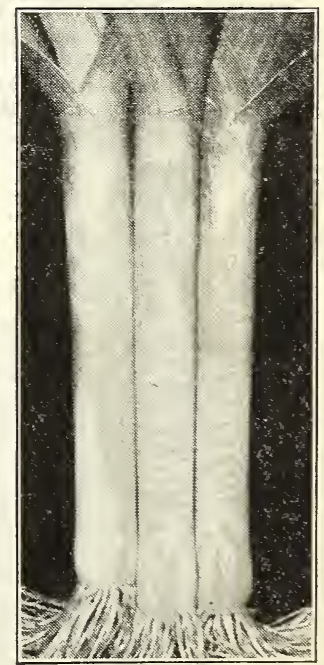

Giant Canadian Leek. 



\section{Lettuce-Other Head Varieties}

LETTUCE CULTURE (Outdoor Planting). Lettuce can be sown either broadcast or drilled in rows, but in either case must be thinned out, leaving the plants about 6 inches apart, so that they may have room to form a head. Before planting the seed, however, the ground must be thoroughly worked and a perfect seed bed must be prepared. Immediately after the third leaf starts to show start thinning and hoeing; being sure to cut out all the small weeds. To assure perfect, well-headed lettuce, patches should be hoed and weeded three or four times through the growing period.

CULTURE (For Winter Forcing). Make sowings from September to February. Sow the curled varieties about every four weeks, the Head or Cabbage sort about six weeks apart. As one crop is cut out another may be planted. For early Spring crop sow under glass in January or Fobruary, and transplant in the open. For Fall planting, sow the hardy varieties in September and transplant, when large enough, to cold varieties in September and
frames nine inches apart.

ICEBERG. This is not the same as Mountain Iceberg, but is planted in districts where a little warmer weather is experienced. A besutiful lettuce, with large, curly leaves of a bright, light green, with a very slight reddish tinge at the edges. Handsome heads, unusually solid because of the natural tendency of the large, strong leaves to turn in, which causes thorough blanching. Crisp, tender, and of fine flavor. Pkt., 5c; $1 / 2$ oz., 10c; 1 oz., 20c; $1 / 4$ lb., 50c; 1 lb., \$1.50.

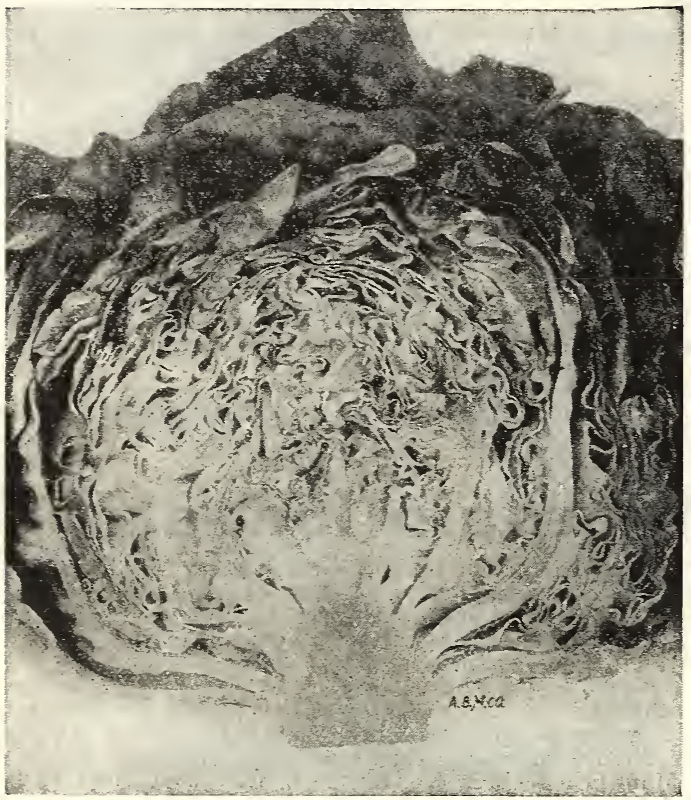

Big Boston Head Lettuce.

DENVER MARKET. While this let. tuce is classed as a leaf variety, under favorable weather conditions it heads up fairly well. The leaves are long, wel curled and crinkled. It is an excellent home garden variety and a quick grower. Adapted to both early and late planting. Pkt., 5c; 1 oz., $10 \mathrm{c}$; $1 / 4 \mathrm{lb}$. $35 \mathrm{c} ; 1$ lb., $\$ 1.00$.

PRIZE HEAD. A large, loose-headed variety; leaves are large and very curly, bright green color; tinted on the edges with reddish brown and very crisp and of fine flavor. Not considered very profitable for the market, but one of the profitable for the market, but one of the
most desired for home gardens. Pkt. most desired for home gardens. $P$

BLACK SEEDED SIMPSON. Forms large, loose heads leaves thin and exceedingly tender, of light green color; used for forcing and outdoor planting. Pkt., 5c; large size pkt., 10c; oz.. $15 \mathrm{c} ; 1 / 4$ lb., $35 \mathrm{c}$; 1 lb., $\$ 1.00$.

EARLY CURLED SIMPSON. Also known as White Seeded Simpson; a loose headed variety, leaves much crumpled. Pkt., 5c; oz. $15 \mathrm{c} ; 1 / 4 \mathrm{lb}$., $40 \mathrm{c}$; $1 \mathrm{lb}$., $\$ 1.25$.

COS LETTUCE or SALAD ROMAINE. Much esteemed for its fresh crispness. Leaves are long, smooth, narrow, spoon-shaped, folding into loose beads. Culture same as other lettuces. Pkt., 5c; large pkt., 10c; oz., $15 \mathrm{c}$; $1 / \mathrm{s} \mathrm{lb}$., $35 \mathrm{c}$; $1 \mathrm{lb}$., $\$ 1.00$.

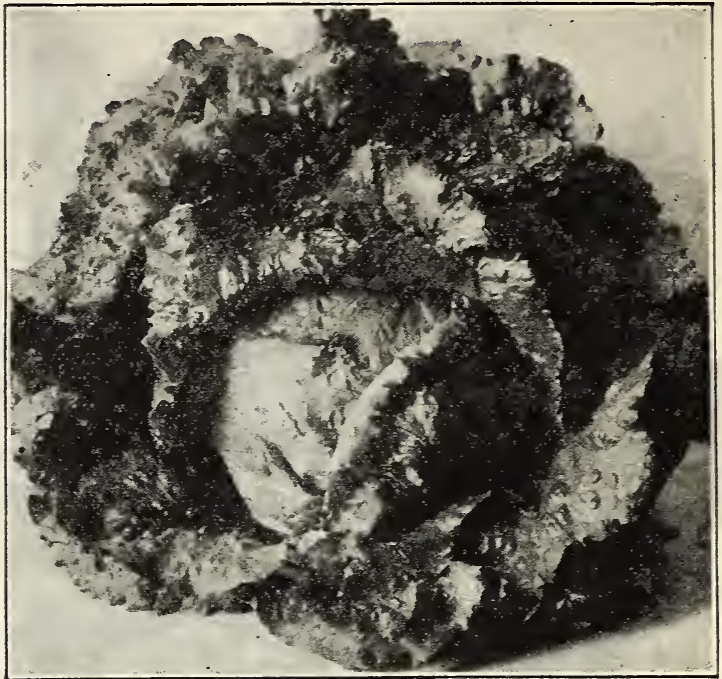

Iceberg Head Lettuce.

HANSON. A very fine large-heading variety; leaves curled on the edges light yellowish green. Heads crisp and brittle, with very fine flavor; very best home garden variety. Pkt., 5c; large size pkt., 10c; oz., 15c; 1/4 lb., $35 \mathrm{c}$; $1 \mathrm{lb}$., $\$ 1.00$.

BIG BOSTON (Gold Seal Quality). A very desirable large variety for forcing in cold frames and for outdoor planting. Plants are large, hardy, vigorous. Leaves broad, smooth, thin, of a light green color with a tint of red on outer edge. It forms good-sized heads and does particularly well during the cool fall and spring months. Heads firm and of superior quality. When grown in cold frames, the heads are not as tight as when grown uutside. One of the best market varieties we know. Postpaid, pkt., 5c; large size pkt., $10 \mathrm{c}$; $1 \mathrm{oz}$., $15 \mathrm{c}$; $1 / 4 \mathrm{lb}$., $35 \mathrm{c}$; $1 \mathrm{lb}$., $\$ 1.25$.

\section{Curled or Leaf Varieties of Lettuce}

\section{Prices Prepaid}

GRAND RAPIDS (Gold Seal Quality). Especially adapted for green. house culture in the Winter; also the best leaf lettuce to sow outside for the summer market, and recommended for family use.

Grand Rapids is what is known as a curly or leaf lettuce. It does not form a head but produces beautiful long curly and wrinkled leaves. It has been the favorite of the market gardeners in this vicinity for a number of years. It is extremely early, very hardy, tender, crisp, and of rich green color which makes it a favorite wherever grown.

Grand Rapids Lettuce is an improved strain of the Simpson Lettuce and was never known to fail to produce a good crop. Pkt., 5c; large pkt., 10c; oz., $15 \mathrm{c}$; $1 / 4 \mathrm{lb}$., $40 \mathrm{c}$; 1b., $\$ 1.25$. 


\section{OUR SEEDS ARE} COLORADO GROWN

\section{Watermelons}

PRICES ON

MELON SEED ARE POSTPAID

CULTURE. The soil for watermelons must be light, rich, and sandy, for if grown on a heavy soil the quality will be poor, and they will not be so early. To make certain of raising good watermelons, it is important to prepare hills about 8 feet apart, by thoroughly working into the soil an abundance of well rotted manure. When the ground is warm and there is no more danger of frost, drop 8 to 10 seeds in hills 8 feet apart each way, covering about $\$ 3 / 4$ inch deep. As soon as plants cornmence to run, thin out to three best plants in a hill and cultivate until vines cover the whole ground. For extra early melons use our Hotkaps. See paye 9\%.

KLECKLEY'S SWEET or ROCKY FORD. The finest of mediuin early watermelons, and very popular wherever it has been thoroughly tested. It is of superb luscious flavor. While the skin is perhaps too thin to admit of the melon being shipped very great dis. tances to market, it is most desirable to plant for home use or markets. The melons themselves are very large and oblong in form, with dark green skin, thin rind, which is very brittle. Flesh is bright scarlet with solid heart, deliciously crisp, sugary, and splendid in every way. The melons average from 18 to 20 inches in length by 10 to 12 inches in diameter; of handsome appearance. Ripen early, and are most desirable for the home garden.

Our seed is Colorado grown, and selected from first class, well matured melons. Pkt., 5c; oz., 10c; $1 / 4$ lb., 25c :

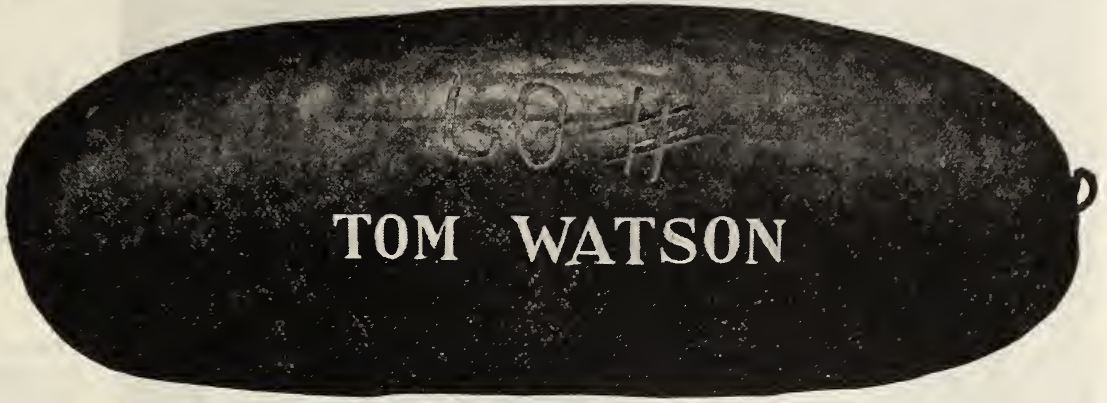
melons. Pkt., 5c; oz., 10c: $1 / 4$ lb.,

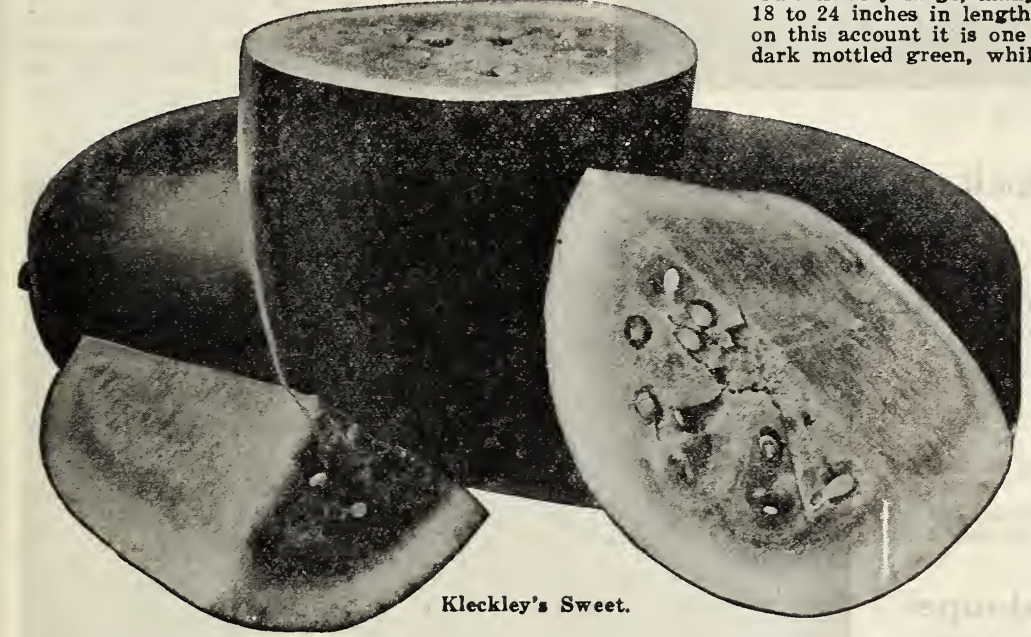

TOM WATSON. A standard in watermelons, and of sterling merit. The fruit is very large, many melons weighing 50 to 60 pounds and measuring 18 to 24 ind is very thin, but exceedingly tough and on this account it is one of the very best shipping varieties. The skin is a dark mottled green, while the flesh is a brilliant scarlet, and the heart is very large with a small seed area. The flavor is most delicious and refreshing. Pkt., 5c; oz., 10c: $1 / 4$ lb., 25c; 1 lb., $75 \mathrm{c}$.

EXCEL. The largest shipping melon yet produced, good flavor, rind dark green and tough duced, good flavor, rind dark green and tough flesh solid, crisp, and sweet, similar in shape to Kleckley Sweet but thicker. Melons cut big red
hearts, showing few seeds. It is a very prolific melon. The seeds are both black and white. Pkt. 5c; oz., 10c; 1/4 lb., 30c; 1 lb., 90c; 5 lbs., $\$ 4.00$; 10 Ibs., $\$ 7.50$.

GEORGIA RATTLESNAKE. One of the oldest and most popular sorts, and frequently known as Gypsy. A large oblong variety with decided stripes of light and deep green. Rind is tough, but the flesh is of good quality and bright red; a good shipping and market melon. Plt., 5c; oz., 10c: $1 / 4$ lb., 25c: 1 lb., 75c.

ROCKY FORD. Same as Kleckley's Sweet. HARRIS' EARLIEST. An extra early melon of excellent quality. The fruits are exceptionally large for so early a variety, slightly oval with large for so early a variety, slightly oval with green. The flesh is bright red, sweet, and tender. green. The flesh is bright red, sweet, and tender. tive. One of the best varieties for northern latitive. One of the best varieties for northern lati-
tudes. We tried it for several seasons and are tudes. We tried it for several seasons and are Pkt., 5c; 0z., 10c; 1/4 lb., 25c; 1 lb., 75c.

IRISH GRAY. A valuable early melon, for although a grand shipper it is equally fine for the though a grand shipper it is equally fine for the home garden. The color is a distinct mottled gray, flesh red, sweet and crisp and free from stringiness. Our seeds are especially adapted to the Western country. Pkt.,

KLONDIKE WATERMELON. Is different from any other melon: grows medium size: remarkable any other melon; grows medium size; remarkable flavor and sweetness; rind thin but tough; the seeds very small; flesh firm. We especially recommend it to people who grow melons for local 5 markets. Pkt., 5c; $0 z$.

HUNGARIAN HONEY. A new melon imported by us. It is very early and well adapted to short seasons and northern latitudes. Melons are per. fectly round, 10 to 14 inches in diameter, and flesh fectly round, 10 to 14 inches in diameter, and fiesh is brilliant red, sweet, and sugary. Pkt.
$15 \mathrm{c} ; 1 / 4 \mathrm{lb}, 40 \mathrm{c} ; 1 / 2 \mathrm{lb} ., 75 \mathrm{c} ; 1 \mathrm{lb}, \$ 1.25$.

COLES EARLY WATERMELON. One of our best early varieties. It is to be classed as a round melon but is slightly oval and of fairly good size for an early sort. The rind is medium thick; the flesh bright scarlet and of excellent flavor. It is termed one of the sweetest melons in cultivation. A dandy melon to grow where seasons are short and the later kinds do not mature. Pkt., 5c; 0z., 10c; 1/4 lb., 25c; 1 1b., 75 ; lbs., \$3.25, postpaid.

\section{Christmas or Winter Queen Watermelon}

This is a surprise to anyone who grows this melon. It produces good sized melons, almost round and light green to ivory in color. Flesh is bright pink ; is exceptionally sweet, in fact most everybody who has eaten this melon claims it is sweeter than any melon grown. Its flesh is very solid, crisp, and juicy. It ripens the first of September and can be kept until Christmas without losing any of its excellent qualities. It is best adapted to sandy soils. Anyone enjoying watermelons should plant some of these melons. Pkt., 5c; 0z., 15c; $1 / 4$ lb., 50c; 1 lb., $\$ 1.50$,

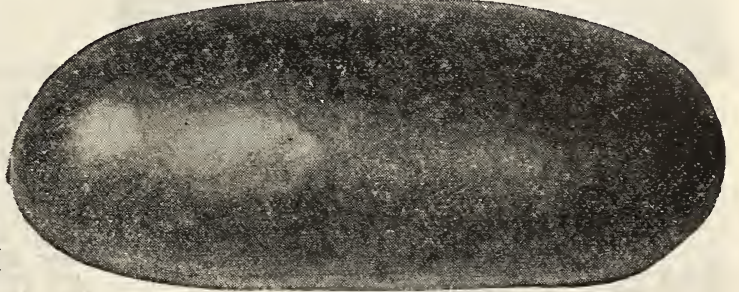

Excel Watermelon. 
s.

\section{Muskmelons and Cantaloupes}

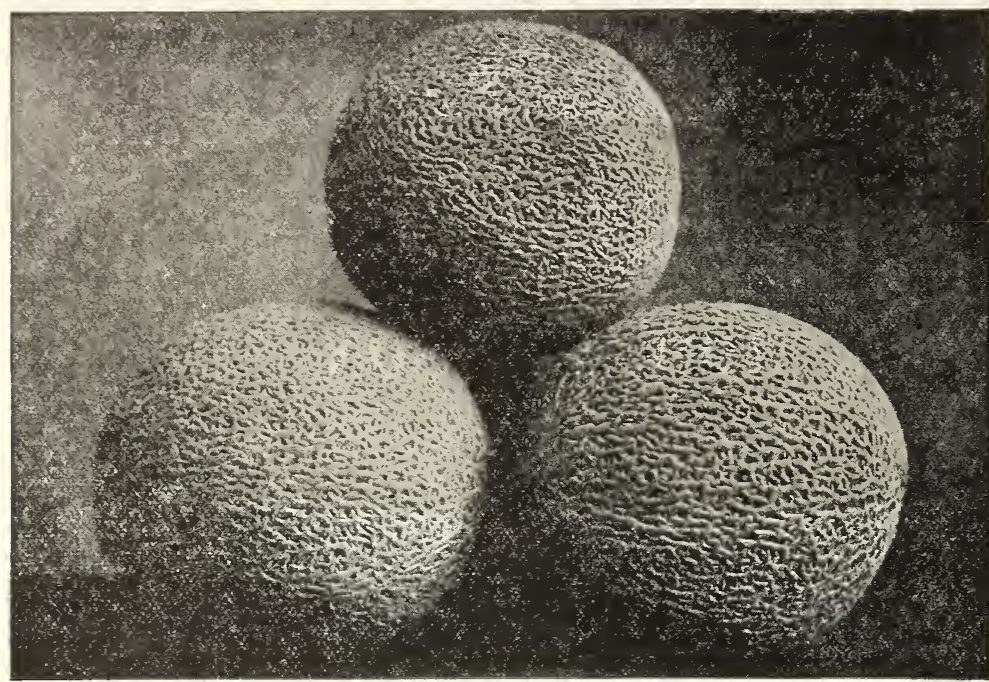

Improved Salmon-Tint Pollock 10-25.

\section{We Specialize in High Grade Cantaloupe Seed}

The Morrison Seed Growers Association, of which Mr. Morrison is the head, have the reputation of producing the best quality cantaloupe seed in Colorado. All their seed is grown on their own farms, under Mr. Morrison's care, and better quality cannot be obtained anywhere. This seed will satisfy the most critical trade and especially those who grow cantaloupes on a large scale for the high class eastern trade.

We are agents for Mr. Morrison's Cantaloupe seed.

CULTURE. A rich, sandy soil and good seed are absolutely necessary for success in raising the best melons. The seed should not be planted until the ground has become dry and warm. Plant in hills 6 feet apart, dropping 8 seeds to the hill. Rich earth is far better than manure but if the latter is used see that it is well rotted and thoroughly mixed with the soil. After danger of frost and insects are past, thin to 3 to 4 of the strongest plants to each hill. Cultivate often but not tou deep.

\section{Improved Salmon-Tint Pollock i $0-25$}

This is the most highly developed of the Rocky Ford Cantaloupes in netting and rust resisting qualities. In the past 4 years, this melon has been planted more than any other variety -especially popular in Colorado, Arizona, and California. In size they run mostly standards. The heavy netting is smooth and regular and more prominent than in any other other melon. The stripe so prominent in the old strain of Rocky Ford is almost eliminated. The flesh is of a salmon tint and the quality and favor is exceptionally fine.

Prices (Morrison's strain): Pkt., 5c; oz., 15c; 1/4 lb., 40c: 1 lb., $\$ 1.25$; 10 lbs., $\$ 10.00$, prepaid.

(Morrison's own growing, selected and hand picked), pkt., $10 \mathrm{c}$; 0z., 20c; $1 / 4 \mathrm{lb}$., 50c; $1 \mathrm{lb}$. to $10 \mathrm{lbs}$., $\$ 1.50$ per lb.; 25 lbs., $\$ 1.25$ per $1 \mathrm{~b}$, prepaid.

New Extra Early H-B Cantaloupe

The most valuable introduction in the cantaloupe family; there never was a cantaloupe put on the market that gave such universal satisfaction; it is the melon that brought the growers in the Imperial Valley such profitable returns in 1925. The fruits are rather large; oblong in shape and somewhat ribbed. Flesh is salmon color, fine grained and excellent flavor. It is a good keeper and shipper, but the fact that it is ten days to two weeks earlier than any other cantaloupe makes it so desirable. Our supply of this seed is limited. Pkt., 10c ; oz., 20c; 1/4 lb., 50c; 1 lb., \$1.50, postpaid.

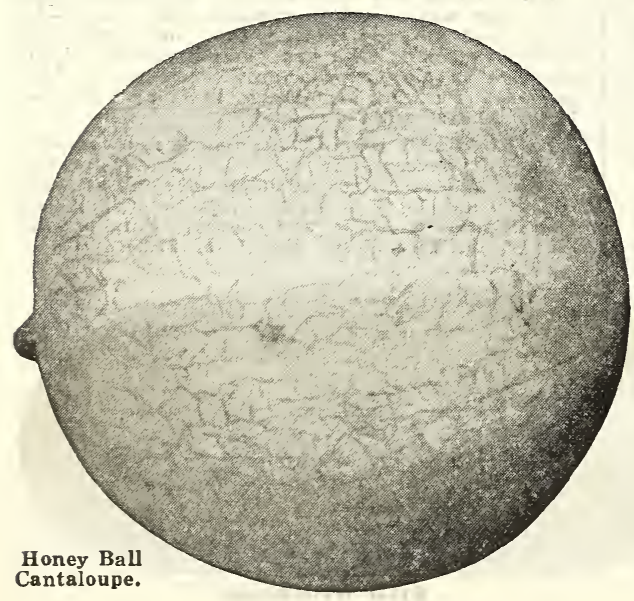

[24]

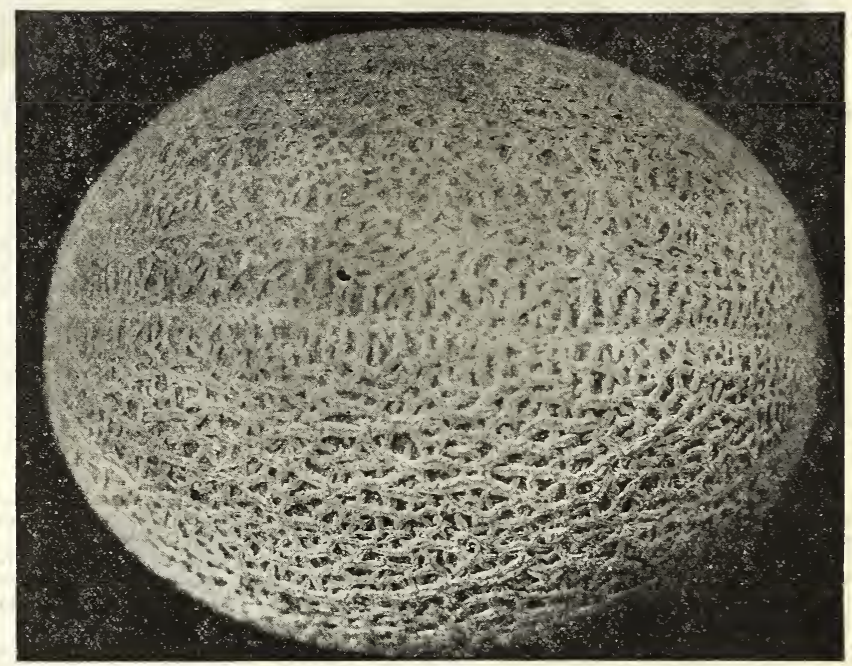

New Extra Early H-B Cantaloupe.

\section{Greeley Wonder Improved Cantaloupe}

It is also one of the earliest muskmelons under cultivation and it produces large melons which resemble the old time muskmelon in shape, having deep ribs, well netted skin and flesh is of richest golden color, one and one-half inches thick, of the finest texture and entirely devoid of coarseness.

It texture and entirely devoid of coarseness. known as flat, it is very much like the best Rocky Ford Melon.

Greeley Wonder will yield more than the Rocky Ford Cantaloupe. Don't fail to include some of this variety in your order. See inside of front cover.

\section{Honey Ball Cantaloupe}

Besides its delightful flavor, it will keep for nearly three weeks without spoiling. You can either leave them on the vine until fully ripe, or you can pull them early and store them. In either case they are at their best when the blossom end be comes soft or gives easily to pressure; they are then fully ripe and make a most delightful dish. Their keeping quality adapts them splendidly for shipping; they ship as well as any other melon and do not bruise easily.

Hon Ball is a cross between the Honey Dew and a perfectly round, thickly netted melon known as Texas Cannonball. It is earlier than the Honey Dew and abe bear after or hot weather better, nor one that is as little affected by long continued dry weather. Pkt., 10c; oz., 20c; 1/4 lb., 60c; lb., $\$ 1.50$. 


\section{Onions}

Prices on Onions Postpaid

C.ULTURE. A crop of onions can be grown on any soil that will produce a crop of corn, but with the liberal use of manure far better results will be obtained. The ground should be plowed in the Fall and in the Spring should be well worked and pulverized, allowing no lumps or trash to mar the surface. The seed should be sown in the latter part of February or first of March, with a hand seed drill, which should be carefully adjusted so as to sow the desired quantity and about $1 / 4$ inch deep. The quantity of seed needed will vary with the soil, the seed used, and the kind of seed. As soon as they show through the ground give them a very light hoeing, and repeat again in a few days, after which weeding must be done, and must be repeated whenever weeds appear until the tops die down, then they should be topped and the bulbs allowed to dry before sacking.

WHITE LISBON (Gold Seal Quality). For bunching. This is a very popular variety in Colorado. Also planted very extensively in Europe. While it will make a good sized white bulb, it is grown instead of shallots and onion sets for what is known as table or green onions, for when young the white or candle part of the onion is pure white, long, and slender. It has a good flavor, being mild and sweet. Home gardeners usually plant White Lisbon so as to have table onions all during Summer after those produced from sets are gone. Price, pkt., 10c; oz., 20c; 1/4 lb., 65c; 1 lb., \$2.00; 5 lbs., \$9.00.

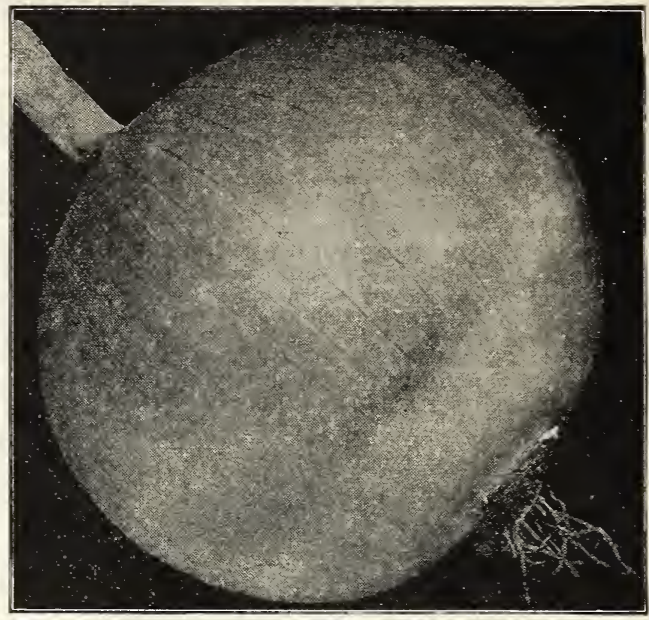

Mammoth Silver King.

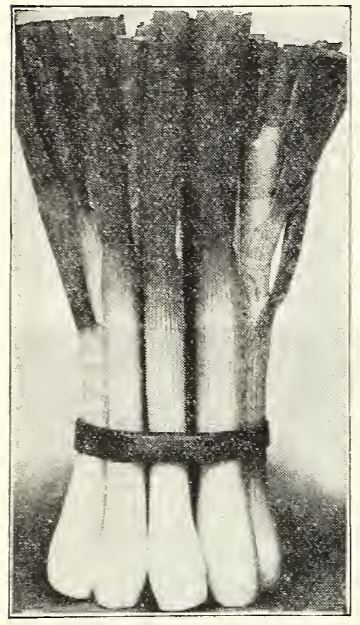

White Lisbon.

MAMMOTH SILVER KING. The largest silver skin onion grown, but not early. It matures along with Danvers Yellow Globe and produces a large, almost round, solid bulb that can be stored for winter use. But on account of its large, perfect shape and pure white color it is planted extensively as a boiling onion, in which case it is pulled green and bunched. Pkt., 10c: oz., 30c; $1 / 4$ lb., 90c; 1 lb., $\$ 2.50$.

EXTRA EARLY WHITE BARLETTA (Imported Strain). The earliest onion in cultivation, maturing when about the size of a marble. On account of its small size and mild flavor it has become the most popular pickling onion grown. And just before it starts to form a bulb it makes an extremely pretty bunch onion. To produce pickling onions, seed must be sown

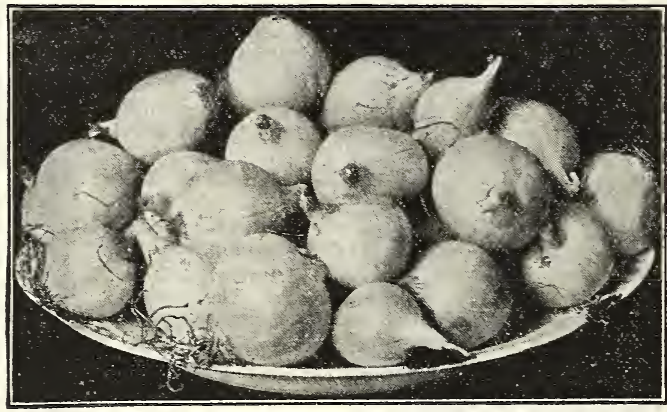

Extra Early White Barletta. very thick. Pkt., 10c; oz., 25c; $1 / 4$ lb., $80 \mathrm{c} ; 1 \mathrm{lb} ., \$ 2.50 ; 5$ lbs., $\$ 11.00 ; 10$ lbs., $\$ 20.00$.

SOUTHPORT WHITE GLOBE. The onions are two to two and a half inches in diameter, with a thin, delicate skin of purest paper whiteness. The flesh is crisp, fine grained, snowy white in color, and very mild in flavor. The bulbs should be stored in a cool, dark loft or shed to dry as soon as they are ripe enough to harvest. Best white winter onion. Pkt., 10c; oz., $30 \mathrm{c} ; 1 / 4 \mathrm{lb}, 90 \mathrm{c} ; 1 \mathrm{lb}$., \$2.75.

WHITE PORTUGAL. An early white, flat variety of good keeping qualities. Used very extensively as a boiling onion; also grown for a table onion; a favorite with set growers. Postpaid, pkt., 10c; oz. $20 \mathrm{c} ; 1 / 4$ lb., $65 \mathrm{c} ; 1$ lb., $\$ 2.00 ; 5$ lbs., $\$ 9.00$.

PRIZETAKER (Gold Seal Quality). We consider this the best onion for the market gardener who desires a large, early onion to supply the early demand and bring good prices which usually follow after the onions grown from sets have been marketed. They produce an enormous yield of large, solid bulbs, and being a Spanish variety, this onion is milder than any of the Danvers. Although it has wonderful merits, it should be marketed before the middle of November, as its keeping qualities are limited to only a few months. Even better results may be obtained from this wonderful onion when the seed is started in hotbeds and transplanted into the open. This onion is often sold in competition with the imported Spanish onion. Pkt. $10 \mathrm{c}$; oz., 25c; 1/4 lb., 75c; 1 lb., $\$ 2.25 ; 5$ lbs., $\$ 10.00$, postpaid.

WHITE VALANCE, SILVERSKIN. A standard boiling onion of silvery white color forming fine, firm bulbs. It should be planted as a main cropper for boiling onions and the young, tender plants are much relished for table use. Pkt., 5c; large size pkt., 10c; oz., 25c; $1 / 4$ lb., 80c; 1 lb., $\$ 2.50$.

GIANT WHITE ITALIAN TRIPOLI, or EL PASO. A large, beautiful, pure white flat onion of mild, excellent flavor, producing somewhat larger bulb from seed than our White Valance. To attain full size the seed should be started very early in a hotbed and the plants set out in rich soil. Pkt., 10c; oz., 30c; 1/4 1b., 90c; 1 lb, \$2.75.

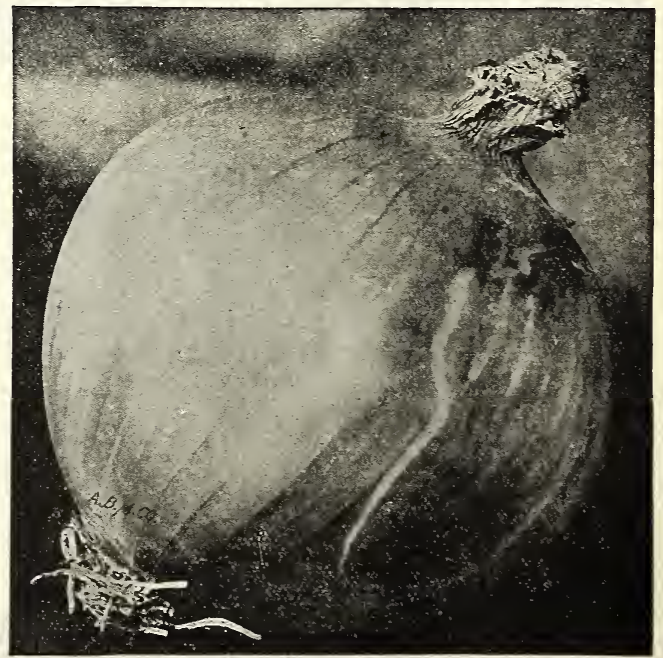




\section{ONIONS-Continued}

YELLOW GLOBE DANVERS. This is a fine, large globe-shaped onion with a rich light brown color. It ripens uniformly and early; almost every plant makes a solid bulb. It is one of the earliest onions to grow as it is of very sturdy habit; produces very few scallions. We do not hesitate to recommend it to all growers who want a fancy and large market onion. While it is not as good a keeper as the David Crockett, yet it can be held until March. We especially recommend this onion to growers who plant large quantities for the shipping trade. Pkt, 10c; oz., 20c; 1/4 lb., 65c; 1 lb., $\$ 1.90 ; 5$ lbs., $\$ 9.50$, postpaid.

MOUNTAIN DANVERS. Account of enormous yield of bulbs it is generally considered by onion growers to be the best type of semi-globe shaped onion in existence. It has a distinct and attractive shape, handsome, bright and even in color, ripens early and all at once. Necks are very small. The bulbs are firm and solid, very good keepers. It is especially adapted to heavy soils and shert seasons. Pkt., 10c; oz., 25c; $1 / 4 \mathrm{lb}, 75 \mathrm{c} ; 1 \mathrm{lb}, \$ 2.25$; 5 lbs., $\$ 10.00$, postpaid.

OHIO YELLOW GLOBE. One of the best yellow globe varieties. The skin is bright, glossy orange yellow; flesh white. The bulbs are remarkably uniform in size and shape and very firm. It possesses good keeping qualities. It ripens a few days later than the Yellow Globe Danvers. Price, pkt., 10c; oz., 20c; $1 / 4$ lb., 70c; 1 lb., $\$ 2.00 ; 10$ lbs, $\$ 20.00$, postpaid.

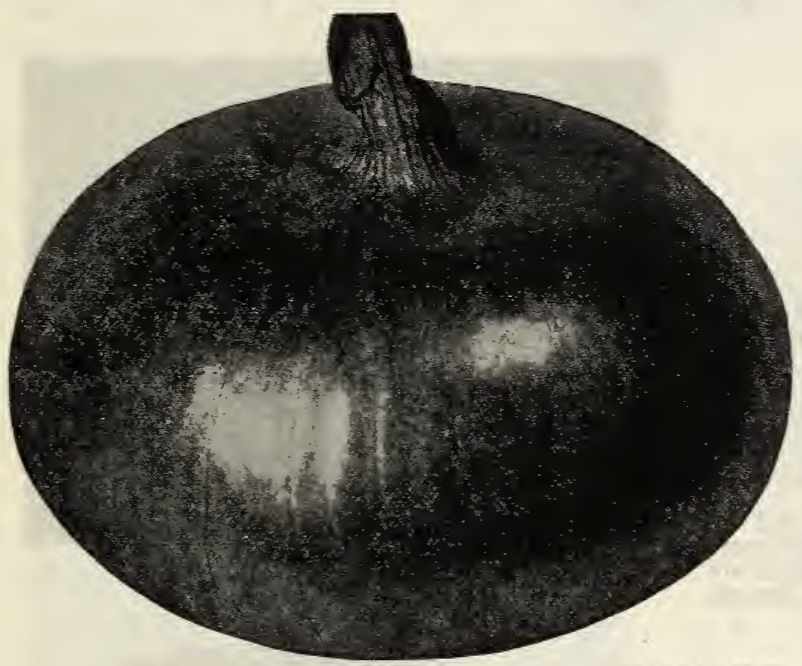

Mountain Danvers.

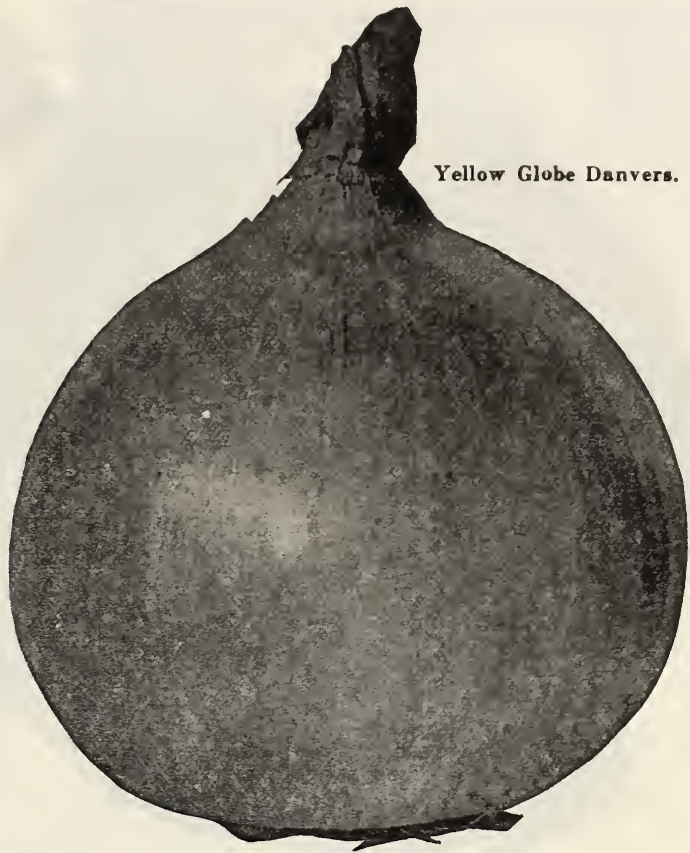

SOUTHPORT YELLOW GLOBE (Gold Seal Quality). Southport, Conn., has for many years been famous for the extra fancy onions which are shipped from that point to the principal eastern markets. These onions have been brought up to the highest standard. Productiveness, uniformity in size and good keeping have been bred into them. They produce large, perfect globe-shaped bulbs, and the color of the skin is brownish yellow while the flesh is white, fine-grained, crisp, and mild. Price, pkt., 10c; oz., 25c; $1 / 4$ lb, 75c; 1 lb, $\$ 2.00 ; 10$ lbs., $\$ 19.00$, postpaid.

YELLOW FLAT DANVERS. A good early onion, both for the home garden and for market, combining reliability in ripening with a large yield. It ripens more surely, as well as earlier, in moist locations than do the globe-shaped varieties. The thin-necked flattened bulbs are quite thick through; light yellow skin; fine-grained, mild, white flesh. Pkt., 5c; oz., 20c; 1/4 lb., 65c; 1 lb., \$2.00; 5 lbs., \$8.00, postpaid.

AUSTRALIAN BROWN. An extra early, sure crop and long keeping onion; of medium size, wonderfully hard; ver attractive, both as to form and appearance; color of skin is a clear amber brown, being widely contrasted from any other onion. Pkt, $5 \mathrm{c}$; large size pkt., $10 \mathrm{c}$; oz., $25 \mathrm{c}$; $1 / 4 \mathrm{lb}$, 65c; $1 \mathrm{lb}$, $\$ 1.80$; $10 \mathrm{lbs}$., $\$ 18.00$, postpaid.

DAVID CROCKETT ONION. It is the best keeping large size onion grown. We have seen these onions keep well into June the following year; this is due to the very solid flesh. Account of its shape, it outyields all other standard varieties.

The bulbs run very uniform in size, are oval-shaped with a golden bronze skin, and white flesh. The flovor is very pleasant and much milder than most varieties. It is an extremely good keeper. In 1892 , Mr. Crockett started this strain by selecting the most perfect ovalshaped, thick-skinned bulbs, improving it each year by careful selection, until this excellent variety was finally obtained. Pkt, 5c; large size pkt., 10c; oz., 20c; $1 / 4$ lb., $65 \mathrm{c} ; 1 \mathrm{lb}$., $\$ 2.00 ; 10$ lbs., $\$ 17.50$, postpaid.

SWEET SPANISH (Valencia Riverside Strain). Sweet Spanish, as the name implies, is a sweet mild onion. Until recently this onion was grown almost entirely in Spain and large quantities were imported into this country. There are several different strains, known by the names of the district in Spain where they are grown, as Denia, Gandea, Barcelona, Valencia, etc. The strain which has proved the most satisfactory in this country is Valencia Riverside strain. The name Riverside was added to Valencia because the seed produced at Riverside is far better than any other, being milder, sweeter, more uniform in size, averaging $21 \%$ to 3 inches in diameter, covered with good, dark bronze skin. An average yield of 400 sacks per acre and 550 sacks are not uncommon in Colorado. In the Arkansas valley, they can be drilled right in the fields, but in altitudes and climate equal to Denver it is best to start the plants in hotbeds or coldframes, or we can supply onion plants of this variety. See prices on onion plants. Pkt, $15 \mathrm{c} ; \mathrm{oz}_{2}, 45 \mathrm{c} ; 1 / 4 \mathrm{lb}, \$ 1.25 ; 1 / 2 \mathrm{lb}, \$ 2.25$, $1 \mathrm{lb}$, $\$ 4.00$; 10 lbs., $\$ 3.75$ per lb.

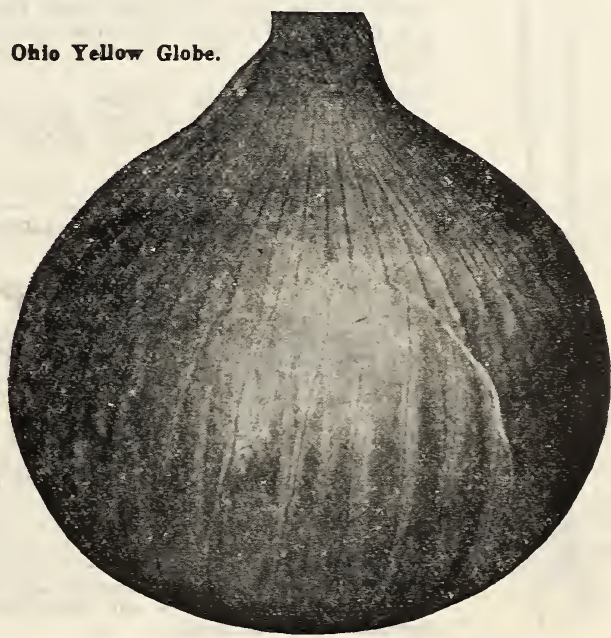




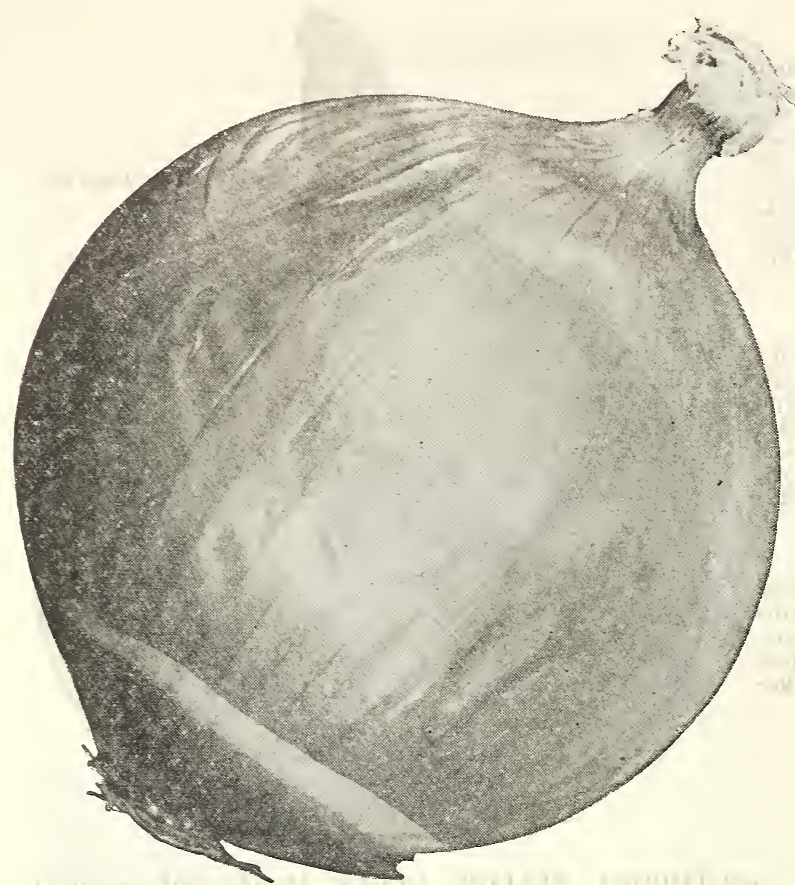

Sweet Spanish-Valencia Riverside Strain.

\section{ONIONS-Continued}

DENIA ONION. A large Spanish onion. An enormous yielder. It is a very desirable variety with the consuming public because of its very mild flavor. It is earlier than the Giant Gibraltar and skin a little darker. In altitudes of 5,000 feet or less it grows very successfully. Pkt., 10c; oz., $25 \mathrm{c}$; $1 / 4$ lb., $80 \mathrm{c}$; lb., $\$ 2.25$.

\section{Red Varieties}

SOUTHPORT RED GLOBE (Gold Seal Quality). The best red onion for the markets, and the only one that should be planted for the main crop of red. In growth, habit, shape, size, and yield, it resembles the Southport Yellow Globe. The skin is of the deepest red color and the flesh solid and fine grained. As a keeper it is to be compared to the Yellow Globe, for it has been known to hold its color and weight longer than any variety of yellow or red onion. When growing red onions for the market plant Southport Red Globe. Pkt., 5c; large size pkt., 10c; oz., 20c; $1 / 4$ lb., $65 \mathrm{c} ; 1$ lb., $\$ 2.00 ; 5 \mathrm{lbs}$, $\$ 9.00$, postpaid.

LARGE RED WETHERSFIELD. We have a very fine and select strain of this sort. Color deep purplish red, flesh white, moderately grained and very firm. Yields an enormous amount per acre and is one of the best keeping onions. Pkt., 5c; large size pkt., $10 \mathrm{c}$; oz., 20c; $1 / 4 \mathrm{lb}$., 65c; $1 \mathrm{lb} ., \$ 2.00$; 5 lbs., $\$ 9.00$.

\section{Bermuda Varieties}

RED BERMUDA. Very flat and of a light pink color. The flesh is white, slightly suffused with pink. Postpaid, pkt., 5c; 1 oz., 25c; $1 / 4$ lb., 90c; 1 lb., $\$ 3.00$.

YELLOW BERMIUDA. The bulbs are quite broad and flat in form; flesh crisp, solid and mild in flavor; skin is light yellow. The plants are extremely thin-necked, insuring even and early ripening. Postpaid, pkt., $5 \mathrm{c}$; large size pkt., $10 \mathrm{c} ; 1$ oz., $30 \mathrm{c} ; 1 / 4 \mathrm{lb}$., $\$ 1.25 ; 1 \mathrm{lb}$., $\$ 4.25$.

CRYSTAL WHITE WAX. A pure white variety, very flat and extremely early. It is of the Bermuda type and the best strains come from the Canary Islands from where we get our supply. These are the beautiful White Onions we see in our markets in early Spring. Pkt., 10c; oz., 60c; $1 / 4$ lb., $\$ 1.90 ; 1$ lb., $\$ 6.00$.

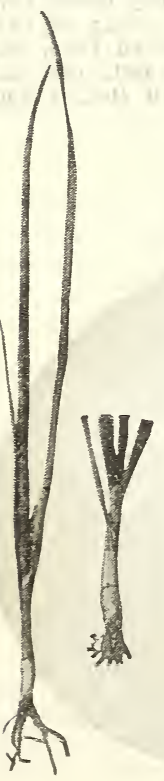

\section{ONION SETS-COLORADO GROWN}

One quart of Onion Sets will weigh one pound. There are 32 pounds in a bushel of Onion Sets.

Bottom Sets, when planted, will produce good green or table onions much earlier than if grown from the seed. If allowed to remain in the ground, will yield fine large onions for market or for household use the ground, will yield fine large onions for market or for

fully four weeks earlier than if planted from the seed. Yellow Danvers Sets, bottom ............\$0.30 $\$ 0.80 \quad \begin{aligned} & \text { Qt. } \\ & \$ 2.75\end{aligned} \$ 5.00$

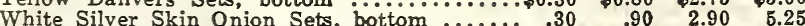
Red Wethersfield Onion Sets, bottom ...........30 $\quad .80 \quad 2.75 \quad \ldots .500$ Top or Button Sets ........................ $.30 \quad .80 \quad 3.00$

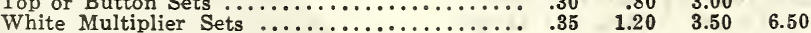

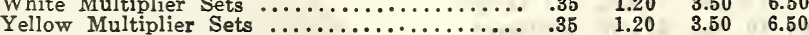
Special: One quart each red, yellow and white onion sets, not postpaid, $70 \mathrm{c}$.

\section{ONION PLANTS}

Also see page 41 . These plants are field grown, which makes them very hardy; however, all plants deteriorate more or less, and in order to save time and have them arrive in the best possible condition, we fill all large orders for a crate or more direct from the growers. For less amounts, we supply from stock which we carry at Denver. These plants are put up 100 in a bunch or 6000 in a crate. We will be glad to supply any amount.

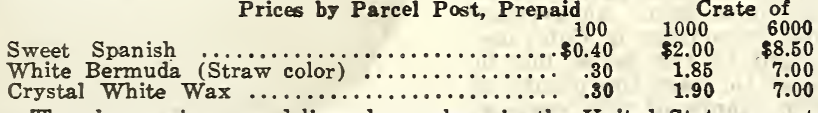

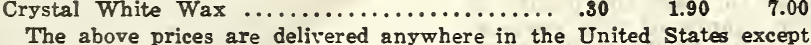
Utah, Montana, Nevada and Wyoming, where an extra charge of 90c per crate will be made. 


\section{Mushroom Spawn}

We offer below the following standard Pure Culture varieties: One Brick, postpaid, 35c; 5 Bricks, postpaid, \$1.50. Not postpaid, 10 Bricks, $\$ 2.25 ; 25$ Bricks, $\$ 5.00$.

With every order of 5 Bricks or more, we will send a 4-page leaflet on Mushroom Culture free.

American Spore Culture Spawn, produced from the original spores of the best varieties, gathered, germinated and propagated under the famous French process. Positively the most vigorous and prolific spawn on the market.

Lambert's Pure Culture Spawn, produced by the tissue culture method. The spawn which has held the market for so many years, and has given universal satisfaction.

\section{Mustard}

\section{Prices Postpaid}

GIANT SOUTHERN CURLED. Very large variety, forming a great mass of beautiful leaves which are ruffled and finely curled on the edges. Pkt., 5c: oz. 10c: $1 / 4$ lb., 30c; 1 lb., 90c

FORDHOOK FANCY. The dark green leaves of this variety are more curled on the edges than any other sort. Pkt., 5c; oz., 10c; 1/4 lb., 20c; 1 lb., 75 c.

WHITE LONDON or COMMON. The leaves are light green, mild and tender when young, the seeds of a light yellow color. Pkt., 5c; oz, 10c: $1 / 4$ lb., 2ac; 1 lb., 60c.

OSTRICH PLUME. The most beautiful of all mustards. The leaves are long, ruffled and curled as gracefully as an ostrich ed as graceruly as an ostrich plume. Stands summer heat splendidly, esteemed as salads $5 c$; oz., $15 c$; $1 / 4$ lb., $30 c$; lb., 90 .

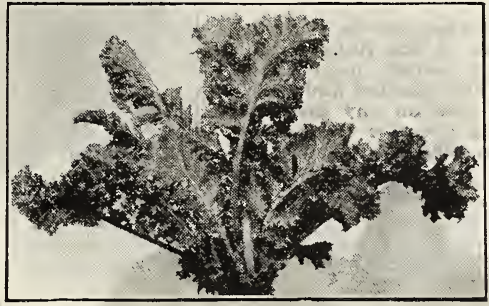

Giant Southern Curled Mustard.

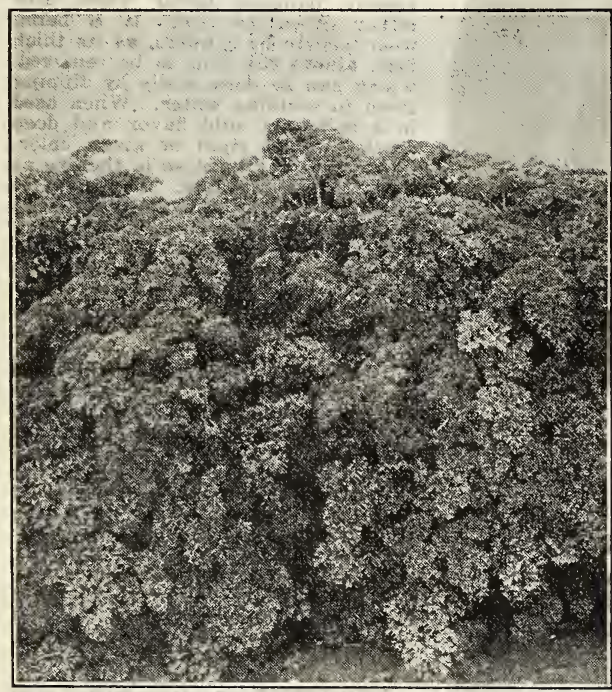

Champion Moss Parsley.

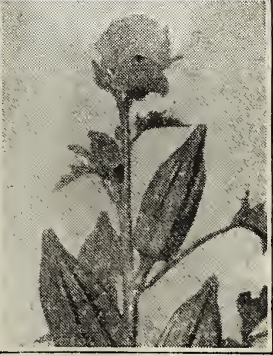

Dwarf Green Okra.

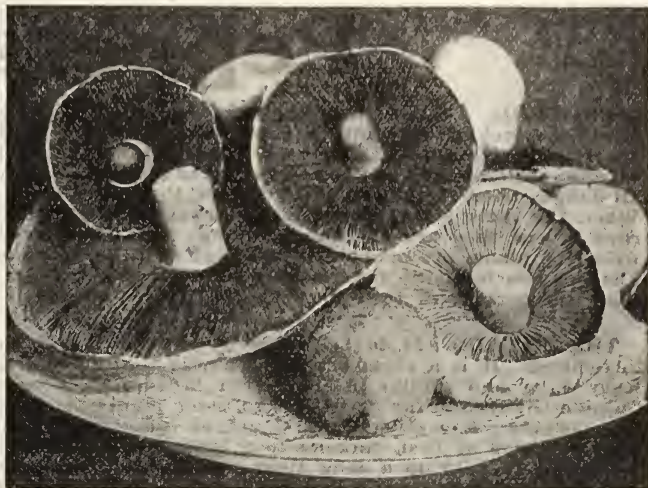

Mushrooms.

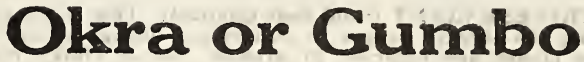

Prices Postpaid

CULTURE, When the ground has become warm. sow thickly in drills 3 feet apart, and when large enough thin out to a foot apart in the rows. One ounce will sow 30 feet of drill.

DWARF GREEN OKRA. The plants are dwarf, close pointed, producing thick fieshy pods of exceptional tenderness and flavor. Pkt., 5c; oz., 10c; $1 / 4$ lb., 20c; 1 lb., 60c.

TALL or PERKINS MAMMOTH. The long pods, measuring 4 and $\bar{b}$ inches, are produced in great quantities: Handsome appearance, color green, of fine quality. Pkt.; 5c; oz., $10 \mathrm{c}$; $1 / 4 \mathrm{lb} ., 20 \mathrm{c}$; 1 lb., $60 \mathrm{c}$.

\section{Parsley \\ Prices Postpaid}

Parsley is used mostly for seasoning and garnishing. Its flavor is exceptionally pleasant and aromatic. As the seed germinates very slowly it should be sown early in the Spring in rows 1 inch deep and 1 foot apart.

DOUBLE CURLED. This is the most popular parsley used in this section. very fine curled and very ornamental. Pkt., 5c; oz., 10c; $1 / 4$ lb., 30c; 1 lb., $\$ 1.00$.

PLAIN PARSLEY. The leaves of this variety are not curled. Esteemed by many because it has a stronger flavor than the other sorts. Pkt., 5c; oz., $10 \mathrm{c} ; 1 / 4 \mathrm{lb} ., 25 \mathrm{c} ; 1 \mathrm{lb} ., 75 \mathrm{c}$.

CHAMPION MOSS or TRIPLE CURLED. This variety is entirely distinct, making remarkably handsome, compact plants, which have leaves so crumpled and curled as to give them the appearance of finely curled moss. The finest parsley for garnishing. Pkt., 5c oz., 10c; $1 / 4$ lb., 30c; 1 lb., $\$ 1.00$.

HAMBURG ROOTED or GERMAN PARSLEY. Roots resemble small parsnips and are used as a vegetable, same as salsify. Foliage same as plain parsley. Pkt., 5c; oz., 10c; $1 / 4$ lb., 30c; 1 lb., $\$ 1.00$.

\section{Parsnips}

Prices Postpaid

CULTURE. Work the soil very deep and pulverize the surface thoroughly. Sow the seed in early Spring, $3 / 4$ of an inch deep, in rows 12 to 18 inches apart. As soon as the young plants appear, cultivate and hand weed them, and when 3 inches high thin to 6 inches apart in the row. Cultivate sufficiently to keep the soil loose throughout the season. Freezing improves the quality of parsnips for table use, so it is customary to take up in the Fall when the ground begins to freeze what so it is customary to take up in the Fall when the ground begins to freeze what or better still, pitting them as is often done with other roots so that access may be had to them at any time. One ounce of seed for 200 feet of row 5 lbs, seed required for an acre.

The parsnip is not eaten by many people. This is no doubt due to the way it is cooked. Most all are familiar with the parsnip served boiled with butter or mashed, but until you have tried them fried, they are not appreciated. Boil the parsnip about fifteen minutes then peel and slice, and fry in butter, lard or compound until brown-a little syrup may be added. Many people prefer these to sweet potatoes. LONG SMOOTH. Very nice parsnip, but grows too long for planting in this section. Pkt., 5c; oz., 10c; 1/4 lb., 35c; 1 Ib., 90c.

GUERNSEY HALF-LONG, HOLLOW CROWN. This is the best variety, and the only sort that should be planted in this territory. Not so long as the Long Smooth and easier taken from the ground. The flesh is fine grained and of excellent quality. Pkt., 5c; oz., 10c; 1/4 oz., 35c; $1 \mathrm{lb} ., 90 \mathrm{c}$, postpaid.

\section{ROOT CROP COLLECTION}

This collection contains root vegetables. Because of their keeping qualities and food value they are being planted extensively each year.

We supply a liberal package of each of the following for $65 \mathrm{c}$ post

paid. Regular price, $\$ 1.00$.

Beets-Extra Early Egyptian

Beets-Early Blood Red

Carrot-Danvers Half-Iong

Celeriac-Turnip Rooted Celery

Leek-Broad London Flag

Onion-Yellow Globe Danvers

Radish-Scarlet Turnip White

Salsify-Mam. Sandwich Island

Turnip-White Egg

Turnip-Purple Top

Rutabaga-Bangholm

25 Potato Eyes-Early Ohio

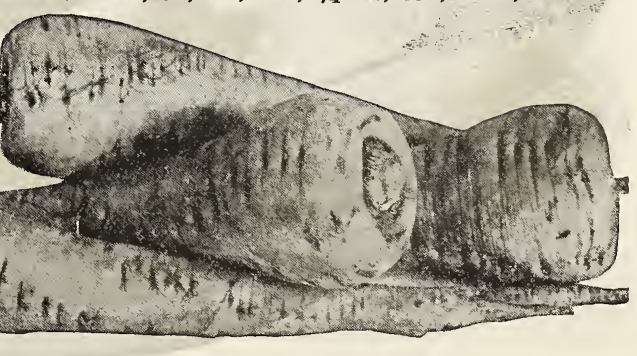

Guernsey Hollow Crown Parsnips. 


Prices
Are
Postpaid

CULTURE. Peppers should be started in a hotbed or cold frame and transplanted about the end of May into a sunny corner of the garden, in rows about 2 feet bout th the apart, with the plants about the same distance between them in the rows. In warmer sections they can also be sown in open ground in a prepared seedbed when all danger from frost has passed, the weather has become settled and the soil warm. rows where they are to remain. Some very rich fertilizer stirred into the coil when the plants are about 6 inches high, will be found very beneficial to the crop. The peppers intended for mangoes should not be grown near the hot varieties, or they will partake of their fery nature.

THE MIKADO (24 to 1). This is, without doubt, the finest large pepper yet introduced. It is a cross between Chinese Giant and Ruby King, fully as early as Ruby King and similar in shape, but broader at blossom end, almost the size of Chinese Giant, and far more prolific, some plants producing as many as 24 marketable peppers. Exceptionally mild, can be eaten raw without fear of burning. Color of lruit green at first, turning to a beautiful shade of scarlet. Flesh thick, which $1 / 402 ., 20 c$; $1 / 4$ oz., 30c; 1 oz., 50c; $1 / 61 \mathrm{lb} ., \$ 1.50$; 1 lb., $\$ 4.50$.

CHIN aSE GIANT (Gold Seal Quality). This is the favorite when size is wanted, being the largest pepper in cultivation, being double the size of the Ruby King. The plants are vigorous in growth, but of stalky habit, are seldom more than 2 feet in height, producing 4 to 6 peppers of enormous size, thick meated and very mild. On account of its enormous size it meets with ready sale on any market. Although not as early as the Ruby King, it matures in ample time for the heavy demand of the shippers. Large plkt., 10c; $1 / 202 ., 35 \mathrm{c} ; 1$ oz., 50c; $1 / 4 \mathrm{lb} ., \$ 1.75$;
$1 \mathrm{lb} ., \$ 5.50$.

RUBY GIANT (Gold Seal Quality). In appearance the fruit somewhat resembles the Ruby King except being larger and a little broader at the base. The Ruby Giant en in this section by us 7 years ego, and now it is the most popular pepper in Colorado. Its dark green per in Colorado. Its dark green color and heary yielding qualities have gained it a place in every gar. the market. Plt, 10e; os, 50c; 1/4 $1 \mathrm{~b}, \$ 1.50$; $1 \mathrm{lb}$, \$5.00.

BULL NOSB or BELL. Most popular cort, belng early and very productive; crows about 2 feet high, fruit remains green a long time. Larze ize pkt., 10e; 1/ oz, 25c; 1 ozo, $40 \mathrm{c}$; $1 / 6$ lb., \$1.35; 1 lbe, \$4.50.

ANAHEIM CRILI. A variety produced in Callfornis and is Inreeis used both dry and lor cannins. It is about 7 inches long and has very thick tesh. While this variets belons to the Cbull class, it is not as pungent as some of the smaller sorts. Plet 10e: or, t0e; 1/4 lb.,

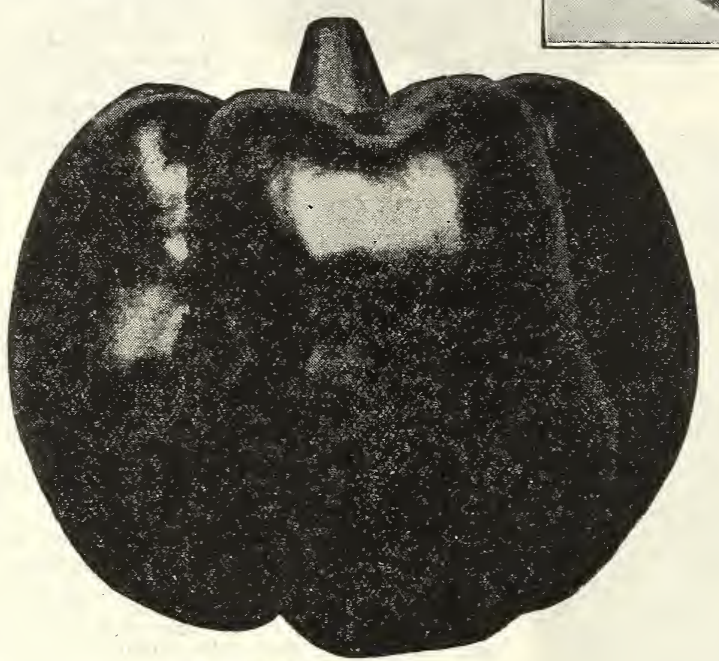

Chinese Giant Popper. 11.40: 1 bo, 425

LONG RED CAYBNNE. A well known varlety, having a lender, twisted and pointed pod bout inches long, bright red in color; extremely strong. Pkt. 10e; $1 / 4$ os, $20 \mathrm{c} ; 1$ ox, 50e; $1 / 4$ Ib., $\$ 1.50$.

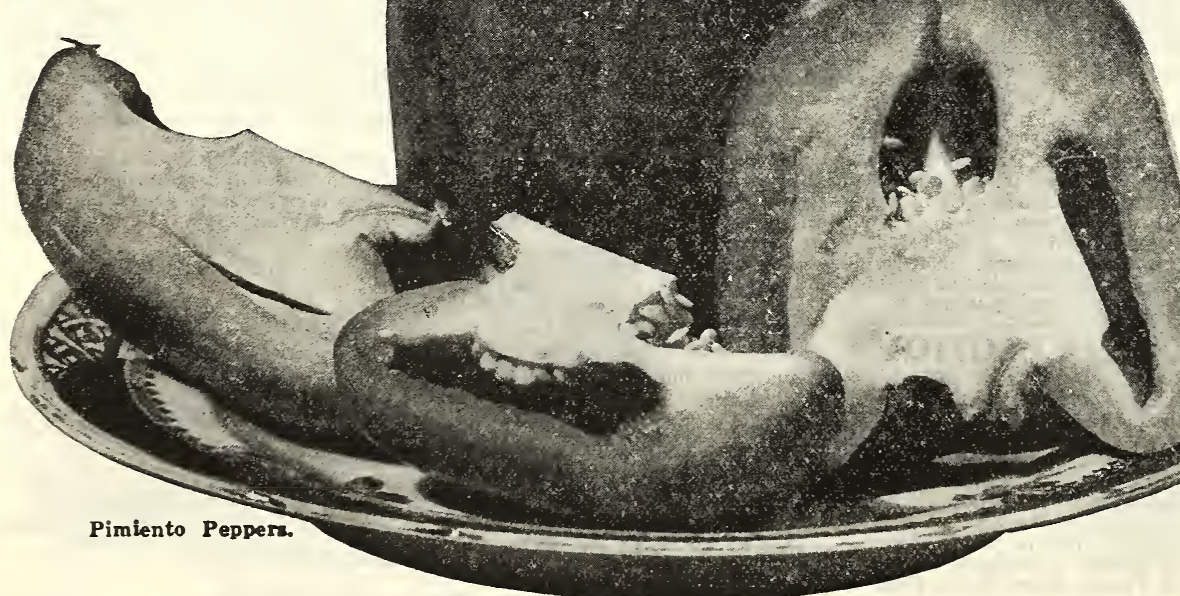

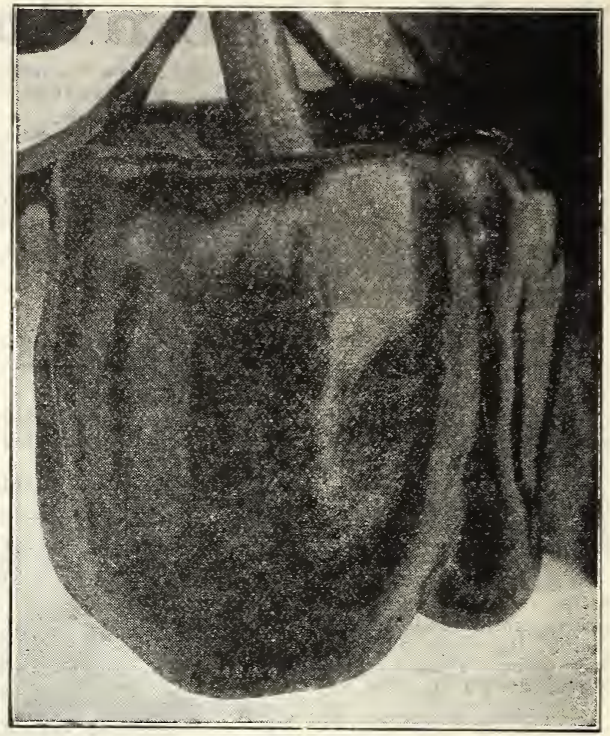

Mikado Pepper.

PIMIENTO or SALAD PEPPER. This variety was introduced from Spain. While not as large as the Chinese Giant it is heavier, on account of its extremely thick flesh, which has a mild sweet, yet deliwhich has a mild, sweet, yet delis ciously pungent havor when ued either green or ripe. It is being flesh allows the skin to be removed, which can be done easily by dipping them in scalding water. When used in a salad its mild flavor and deep scarlet (when ripe) or green color, make it very attractive to the eye as well as to the palate. The plant is very prolific, producing a large number of peppers, each weighing from 5 to 10 ounces. We recommend this new pepper for both the home garden and market supply. $1 \mathrm{lb}$., $\$ 4.50$.

JERSEY GIANT. This is the earliest of all large peppens, almost as large as Chinese Giant and 3 weeks earlier. Plant of dwarf wraks earlier. Plant of dwatr fruits of dabi, bearing fruits of a deep green color, turning to brilliant red, flesh thick and of
mild flavor. Pkt., 15e; oz., 75e: $1 / 4 \mathrm{lb}, \$ 2.50$; $\mathrm{lb}$., $\$ 8.00$.

RUBY KING. Grows about $81 / 2$ to 5 inches long and is often $21 / 2$ to 8 inches in diameter. One of the best varieties for stuffed pickles. Pkt., 10 ; $1 / 4$ oz., 20c; 1 oz., 50c.

RED CHILI. A late variety, used in the manufacture of pepper sauce. Bright red pods are about 2 inches long, tapering to a sharp point, and

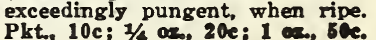

TABASCO PEPPER. This is the Red Hot Mamma of the pepper family and it is grown for the market as well as for making sauce. It as for making sauce. It is pungent and strong, also very prolific. It is easily gathered as the fruit does not adhere to almost rect on the branches. This variets is used in manufacturing the well known Tabasco Sauce. It is splendid for family use. Prices, pkt., 10e: oz. 50c; 1/4 lb., s1.75; Ib., $\$ 5.50$. 



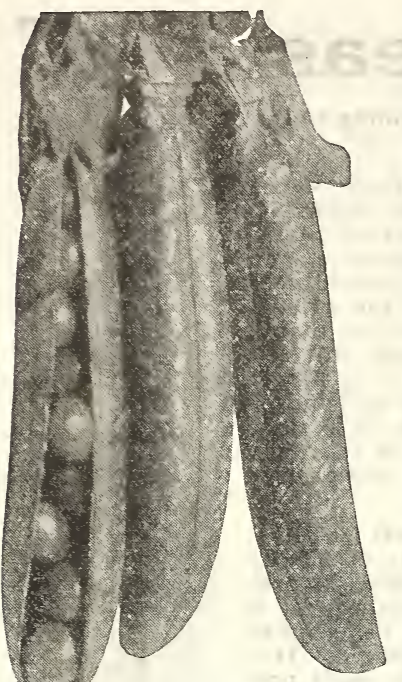

PEAS-Continued

Denver, Colorado

Laxtonian
Peas.

ALASKA. Is the earliest pea on the market. It is ready 73 days from planting. It is the standard extra early market garden variety. It grows about 30 inches tall, matures a crop of uniform pods 3 inches long. The seed is small, smooth, dark green and of good flavor. Our strain is selected for its earliness and heavy bearing qualities. Postpaid, pkt., $5 \mathrm{c}$; large size package, $10 \mathrm{c} ; 1 \mathrm{lb}$., $30 \mathrm{c} ; 2 \mathrm{lbs}$., 60c; $5 \mathrm{lbs} ., \$ 1.40 ; 10 \mathrm{lbs}$., $\$ 2.40$. If by express or freight at purchaser's expense, $5 \mathrm{c}$ per lb. less. $100 \mathrm{lbs}$., $\$ 16.00$, purchaser paying express.

IMPROVED STRATAGEM (Gold Seal Quality). While not so popular in this district, yet this is one of the best peas to grow, especially in our mountain districts, because it is hardy and is a very heavy vielder of fine, well filled pods which measure about $41 / 2$ inches long. Vines are dwarf; grows $2 \frac{1 / 2}{2}$ feet high. Matures in 80 to 90 days from planting. Pkt., 5c; large pkt., 10c; 1 lb, 35c; 2 lbs., 65c; 5 lbs., $\$ 1.50 ; 10$ lbs., $\$ 2.75$. If by express or freight, purchaser paying charges, $5 \mathrm{c}$ per lb. less. $100 \mathrm{lbs}$., $\$ 18.00$, purchaser paying express.

LITTLE GEM. Height, 16 to 18 inches. The vines are of dwarf growth and produce an abundance of round, well filled pods $2 \frac{1}{2}$ to 3 inches long, only three days after the American Wonder. The peas are green, wrinkled, of sweet, delicious flavor and excellent quality. One of the best for family use. It remains fit for use longer than the American Wonder and Nott's Excelsior, and is considered by many to be sweeter. Postpaid, pkt., 5c; large size pkt., 10c; 1 lb., 35c; 2 lbs., $65 \mathrm{c} ; 5$ lbs., $\$ 1.50 ; 10$ lbs., $\$ 2.50$. If by express or freight, purchaser paying the charges, $5 \mathrm{c}$ per $\mathrm{lb}$. less.

TALL TELEPHONE. This variety has been the standard for many years past, but is now being replaced by many improved varieties, the main objection being the tall vines. Pkt., 5c; large size pkt., $10 \mathrm{c} ; 1 \mathrm{lb}, 35 \mathrm{c} ; 2 \mathrm{lbs}, 65 \mathrm{c} ; 5 \mathrm{lbs} ., \$ 1.50 ; 10$ lbs., $\$ 2.60$. If by express or freight, purchaser paying charges, 5c per lb. less. $100 \mathrm{lbs}$., $\$ 17.50$, purchaser paying express.

THOMAS LAXTON. This is very similar to the Gradus, except pods, which are about one-half inch shorter, but very well filled out. Tests show it to be about 2 days earlier than Gradus. Postpaid, pkt., 5c; large pkt., 10c; 1 lb., 35c; 2 lbs., 65c; 5 lbs., $\$ 1.50 ; 10$ lbs., $\$ 2.60$. If by freight or express at purchaser's expense, $5 \mathrm{c}$ per lb. less.

GRADUS (Prosperity). The earliest wrinkled variety. This grand, large podded, early, prolific variety has won the favor of market gardeners everywhere. The vines are very vigorous and robust, growing to a height of about 3 feet. It is not only an abundant producer, but bears continually throughout the season. It is exceedingly early for a wrinkled variety, being only a day or two later than the earliest, small, smooth sorts. The pods are very large and are invariably well filled with from 6 to 9 sweet, luscious, tender, wrinkled peas of large size and delicious flavor. The peas remain tender for some time after they are large enough to use. Postpaid, pkt., 5c; large size pkt., 10c; 1 lb., 35c; 2 lbs., 65c; 5 lbs., $\$ 1.50$; 10 lbs., $\$ 2.50$. If by freight or express at purchaser's expense, $5 \mathrm{c}$ per lb. less. $100 \mathrm{lbs}$., $\$ 18.00$, purchaser paying express.

MAMMOTH EDIBLE POD or LUSCIOUS SALAD PEA. Without an equal for sweetness and tenderness, it is a double purpose pea. The pods when half grown should be sliced and boiled like snap beans and when served with butter or sauce they make a very tempting and delicious dish, or it can be used as a shell pea and is equal to the sweetest wrinkled variety. They are grown the same as any other variety of peas. Pkt., 5c; large pkt., 10c; 1/2 lb., 20c; lb., 35c; 10 lbs., \$2.75, postpaid.

FIRST AND BEST. A smooth variety of early, good quality peas. Pods medium size. Matures about same time as the Alaska. Postpaid, pkt., 5c; large pkt., $10 \mathrm{c} ; 1 \mathrm{lb}$., 35c; 2 lbs., 55c; 5 lbs., $\$ 1.40 ; 10 \mathrm{lbs}$., $\$ 2.50$. If by express or freight at purchaser's expense, $5 c$ per lb. less.

AMERICAN WONDER. This pea, although it produces small pods, seems to win favor with all planters, as it is a very productive little plant, growing 10 to 18 inches high, and the peas are exceptionally sweet. It is easier grown than most of the large podded varieties. Postpaid, pkt., 5c; large size pkt. 10c; 1 lb, 30 ; 2 lbs., 55 c; 5 lbs., $\$ 1.35 ; 10$ lbs., $\$ 2.50$. If by freight or express at purchaser's expense, $5 \mathrm{c}$ per lb. less. 100 lbs., $\$ 17.00$, purchaser paying express.

For Early Vine Crops

Use Our Hotcaps

See Page 92

CULTURAL DIRECTIONS. Sometimes grown in cornfields, but if grown as a separate crop, seed should be planted in hills 8 to 10 feet apart each way after weather and soil get warm. Hoe often till vines begin to run. Cut pumpkins from vine after the leaves die, leaving 3 to 4 inches of stem attached, and store in a dry place. Handle carefully and avoid bruising. Use one ounce of seed to 20 hills of most varieties; 3 to 4 pounds per acre.

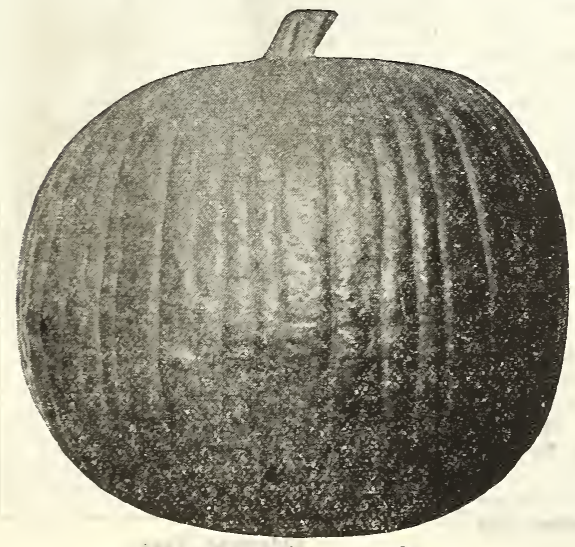

Connecticut Fleld Pumpkin.

KENTUCKY FIELD (or Large Cheese). A fine pumpkin nearly two feet in diameter. Flesh yellow, extra thick, sweet, and of the finest quality. A heavy.yielder and excellent keeper. Prices, pkt., 5c; oz., 10c; $1 / 41 \mathrm{lb} ., 25 \mathrm{c}$; $1 \mathrm{lb}$., 70c; $10 \mathrm{lbs}$., $\$ 6.00$.

SMALL SUGAR. A small round variety; flesh thick, rich yellow, and sweet, skin a deep orange. This is the best variety for pies. Pkt., 5c; oz., 10c; $1 / 4$ lb., 25c; 1 lb., 70c.

CONNECTICUT FIELD. A fine large, orange colored variety, used for field culture and stock feeding. Skin smooth and ribbed; flesh brittle. Pkt., 5c; 0z., 10c; 1/4 lb., 25c; 1 lb., 60c; 10 lbs., $\$ 6.00$.

MAMMOTH TOURS. A very large French variety, grown for stock feeding. Pkt, $5 \mathrm{c}$; oz., $10 \mathrm{c} ; 1 / 4 \mathrm{lb}$., $25 \mathrm{c} ; 1 \mathrm{lb} ., 80 \mathrm{c}$.

JAPANESE PIE. Large size, weighing from 30 to 70 pounds; color of outside rind bluish-green blotched with yellow. Flesh salmon colored very thick and sweet; for eating and stock feeding. Pkt., 5c; oz., 15c; $1 / 4$ lb., $40 \mathrm{c} ; 1 \mathrm{lb}$., $\$ 1.25$.

KING OF MAMMOTHS. The best large pumpkin in use, forming immense muskmelon shaped pumpkin, often $2 \frac{1}{2}$ to 3 feet in diameter; salmon colored; flesh bright yellow. Pkt, 5c; oz., 15c; 1/4 lb, 40c; 1 lb., \$1.25. 


\section{SEED POTATOES-Continued}

EARLY OHIO COLORADO DRY-LAND GROWN. These potatoes are grown for us in the dry lands of Elbert county (known as the Divide). It is our desire to have as many of our customers as possible order our Red River Early Ohios, but those who do not care to pay the advanced price will not be disappointed in our Divide Early Ohios. 5 lbs., $40 \mathrm{c}$; 10 lbs., $70 \mathrm{c} ; 25$ lbs., $\$ 1.25$. For larger amounts, write for special prices. If by parcel post, add postage. By express or freight, purchaser pays transportation.

RUSSET BURBANK. One of the wonderful discoveries of Luther Burbank, and now ranks among the leading varieties of potatoes of the world. For many years this variety has been a great favorite in California, but now it is being grown extensively and with great success everywhere. The Burbank is becoming one of Colorado's best mountain varieties where at one time it was thought only Red Mcclures would mature and thrive. But the Burbank has been proven in this country and on dry land where other varieties have failed, the Burbank has held out against the drought and heat and produced good yields and is now being planted throughout our state on the dry lands. The flesh of the Burbank is white, very mealy, and of fine flavor. The potatoes are long in shape and size and the skin is russet. As a baking potato it cannot be surpassed. 5 lbs., 40c; 10 lbs. $75 \mathrm{c} ; 25 \mathrm{lbs}$., $\$ 1.25$. For larger amounts, write for special prices. If by parcel post, add postage. By express or freight, purchaser pays transportation.

RURAL NEW YORKER. A valuable variety of large size, very smooth and a heavy cropper. In quality it is unexcelled. It is the best late long keeper, and is highly recommended. More potatoes of this sort are shipped annually than any other kind, and their
large, handsome appearance makes them more profitable than any other sort. Planted large, handsome appearance makes them more profitable than any other sort. Planted
very extensively in potato districts, $5 \mathrm{lbs}$. 40c; $10 \mathrm{lbs.} 75 \mathrm{c} ; 25 \mathrm{lbs}$., $\$ 1.25$. For larger a mounts, write for special prices. If by parcel post, add postage. By express or freight, purchaser pays transportation.

\section{ARTICHOKES}

\section{Jerusalem or Potato Artichokes}

Artichokes make an enormous crop of nutritious feed for hogs and cattle. They wiil yield, ordinarily, twice as much as potatoes on the same land. Should be planted and cultivated the same as potatoes, although, where desired, hogs can be turned on them two weeks after the blossoms fall, and allowed to feed on the roots throughout the Winter, except when the ground is frozen.

\section{Potato Eyes By Mail Postpaid}

We send these potato eyes delivered to your door, all transportation charge paid, so that all you have to do is to plant them and harvest a crop. We select the seed potatoes, using only the smoothest and firmest stock that we know will carry the longest after being know will carry the longest after being enough of the flesh to assure a good plant that will produce potatoes. We then pack them in lots of 25 eyes each. all labeled so as to avoid chance of mixing the different varieties. We guarantee these potato eyes to arrive in good planting condition. But we advise, before ordering the eyes shipped from Denver, that you prepare your soil and have things ready for planting on arrival of stock.

They can be sent without any danger of freezing, for they are securely wrapped and packed in pasteboard boxes. We cannot furnish less than 25 eyes of a sort, and those wanting larger amounts should make their orders even multiples of 25 .

Prices (any variety listed)
25 eyes $\ldots \ldots \ldots \ldots \ldots \ldots \ldots, \$ 0.25$
50
100
100 eyes $\ldots \ldots \ldots \ldots \ldots \cdots \cdots, \quad \mathbf{7 5}$

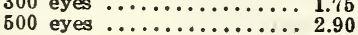

Artichokes are not entirely hardy and it is best not to dig them until ready to feed. They can be planted any time in April, the earlier the better. Plant in rows 4 feet apart, dropping the artichokes 12 to 15 apart, dropping the artichokes 12 to 15 lbs. to plant an acre. 1 lb., 15c; 10 lbs. $90 \mathrm{c}$, postpaid. Write for prices on larger quantities.

\section{SWEET POTATOES}

CULTURE. The plants should be started in hotbeds in March, and after danger of frost, transplanted 2 feet apart in rows $31 / 2$ to 4 feet apart. They do best in sandy, light soil, and should be cultivated often, especially if supply of water is scarce.

YELLOW NANSEMOND. 1 lb., 25c; 10 lbs., $\$ 2.00$.

YELLOW JERSEY. 1 lb., 25c; 10 lbs., $\$ 2.00$

If by parcel post, add postage.

On larger amounts of potatoes, get special prices.

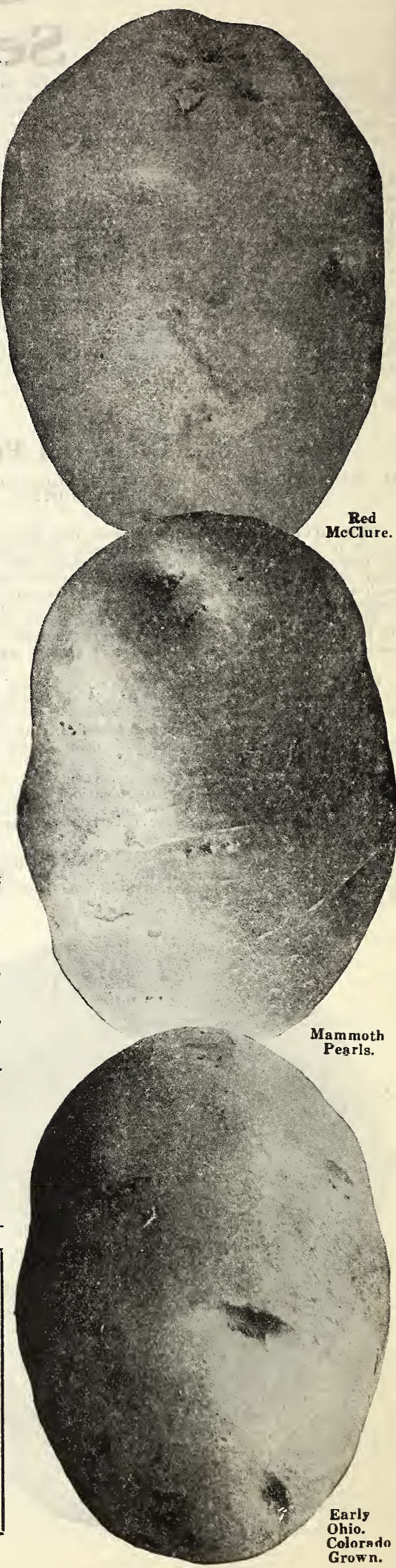

\section{Corrosive Sublimate}

PREVENT SCAB ON YOUR POTATOES AND SMUT IN YOUR WHEAT

Four ounces to 30 gallons of water Put in wood barrel or vat. Dissolve the Corrosive Sublimate in warm water, then add to the cold water.

First lot, treat $11 \frac{1}{2}$ hours.

Second lot, treat $13 / 4$ hours.

Third lot, treat 2 hours.

Then throw out and make a new solution.

Remember, it is rank poison, so don't allow anything to eat the potatoes after being treated.

Allow the treated seed to dry, then cut and plant.

Corrosive kill the scab and Rhizoctonia diseases. extensive experiments carried out in several states it was 95 per cent effective. A soluextensive experiments carried out in several states it was 95 per cent effective. A solus

$1 / 4 \mathrm{lb}$., Corrosive Sublimate, 90c; $1 \mathrm{lb}$., $\$ 2.75$, postpaid.

$1 / 4 \mathrm{lb}$. Corrosive Sublimate, $90 \mathrm{c} ; 1 \mathrm{lb} ., \$ 2.75$, postpaid.
Blue Vitriol and Formaldehyde are also used for treating potatoes. 


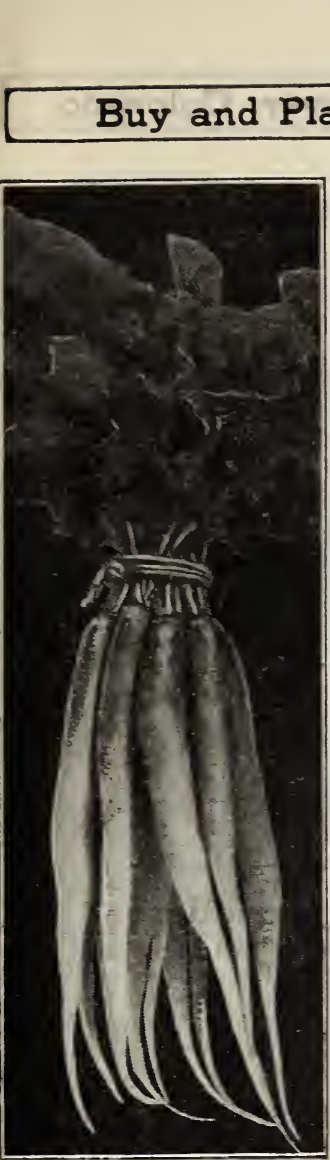

Cincinnati Market.

\section{Radishes}

Prices Postpaid.

\section{SELECTED STOCK}

European grown radishes are far better than we can produce at home. This is mostly.due to labor conditions, for in the selection and transplanting of radishes a great deal of labor is necessary and in this country where labor is so high it seems to be impossible to devote the necessary time and care to the production of the seed. Our radish seed is all European grown and is far better than the general run of radish seed sold by other houses. We suggest you buy ours and compare them with cheaper seed offered by other firms.

CULTURE. To be tender and crisp, radishes must be grown quickly-and quick growth requires rich soil and plenty of moisture. Commencing with the first mild spell of weather in the Spring, sow at intervals of 10 days in a light rich soil that has been deeply dug. They can also be grown as a catch crop between the rows of beets, lettuce, onions, etc. Radishes can be forced in the hotbeds, but they must have plenty of ventilation and moisture.

\section{Long Varieties}

CINCINNATI MARKET (Gold Seal Quality). An improvement of the Long Scarlet variety and one that has met with the approval of all the greenhouse and hotbed gardeners. The seed that we offer of this variety is especially adapted to this Western country, and has been given a thorough trial by us. It produces a long, straight radish of beautiful color, with short tops and for this reason can be planted so thick in the bed that the radishes touch one another. It has also won favor among the growers of outdoor radishes and is being planted as the main crop radish for the summer market. Often grows 7 to 9 inches in length. Pkt., 5c; oz, 10c; $1 / 4 \mathrm{lb}, 30 \mathrm{c}$; $1 / 2 \mathrm{lb} . .60 \mathrm{c}$ :

EARLY LONG SCARLET (Gold Seal Quality). A standard variety of the long type of radish, for both market and home use. Roots long, grown partly above the ground; straight, smooth, and of bright, rich scarlet color, a little white on the end or tip. Pkt., $5 \mathrm{c}$; oz., 10c; $1 / 4$ lb., 30c; $1 / 2$ lb., 50c; 1 lb., 90 c, postpaid.

WHITE ICICLE RADISH (Gold Seal Quality). The favorite white radish grown for the market, also extensively used for the home garden. It is a handsome white trans. parent variety, as crisp as ice, of mild flavor. As seen in the photograph, it is about five inches long with sloping tops and pointed roots. Pkt., 5c; oz. 10c; $1 / 4$ lb., 30c; $1 / 2$ lb., $60 \mathrm{c} ; 1 \mathrm{lb}, 90 \mathrm{c} ; 5$ lbs., \$1.00, postpaid.

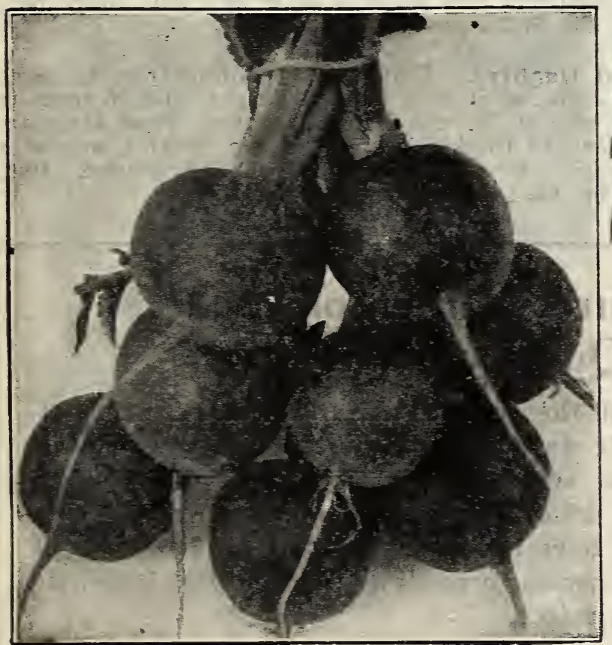

Forcing Scarlet Globe.

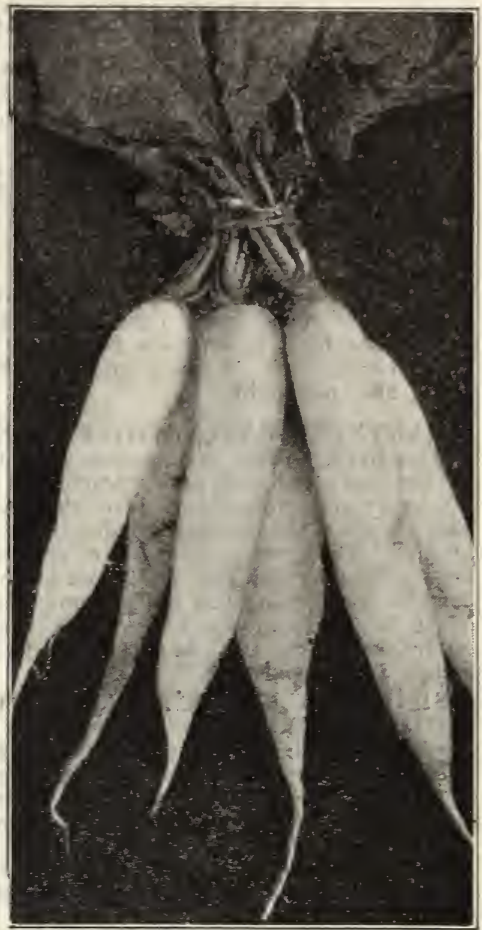

White Icicle.

LONG WHITE VIENNA or LADY FINGER (Gold Seal Quality). An excellent variety with long, very smooth.

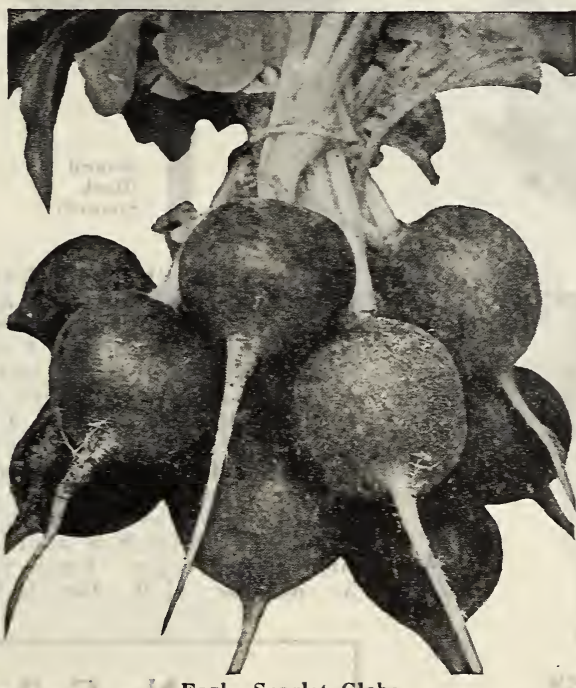

Early Scarlet Globe. white roots, which are crisp and tender. One of the most desirable of the white summer sorts. Pkt., $5 \mathrm{c}$; oz., $10 \mathrm{c}$; $1 / 4$ lb., 30c; $1 / 2$ lb., 50c; $1 \mathrm{lb}$., $90 \mathrm{c}$, postpaid.

\section{Round Varieties}

EARLY SCARLET GLOBE (Gold Seal Quality). This splendid globe shaped radish is one of the finest early strains of round bright radishes; nothing can surpass its table qualities or its beauty. The skin is bright scarlet; flesh pure white, crisp, and tender, and of delicious quality; fine for market gardeners as an early outdoor forcing radish. Pkt., $5 \mathrm{c}$; oz., $10 \mathrm{c} ; 1 / 4 \mathrm{lb}$, 35c; $1 / 2$ lb., $60 \mathrm{c}$; 1 lb., $90 \mathrm{c}$, postpaid.

WHITE GLOBE (Gold Seal Quality). This is a very fine radish and a favorite with all who have tried it. It is a rapid grower: rather small in size with brittle, sweet flesh and pure white skin. Pkt., 5c; oz., 10c; 1/4 lb., 30c; $1 / 2$ lb., 50c; 1 lb., 90c, postpaid.

CRIMSON GIANT (Gold Seal Quality). This extraordinary turnip shaped variety is of a beautiful crimson color, flesh firm, crisp, and tender. Unlike other varieties of round radishes it remains perfect a long time, does not become pithy even when twice its average size. Pkt., 5c; oz., 10c; $1 / 4$ lb., 35c; $1 / 2 \mathrm{lb}, 60 \mathrm{c}$; 1 lb., 90c; 5 lbs., \$4.00, postpaid.

FORCING SCARLET GLOBE (Gold Seal Quality). One of the most desirable radishes for forcing under glass and also good for field culture. It is very attractive, both in shape and color; being a bright transparent red and very smooth skinned. It is a very quick grower and not apt to crack. Pkt., 5c; 0z., 10c; $1 / 4 \mathrm{lb}$., $35 \mathrm{c}$; $1 / 2 \mathrm{lb}$., 60c; 1 lb., $\$ 1.00$, postpaid. 


\section{RADISHES-Continued}

FRENCH BIRAKFAST (Gold Seal Quality). This is an olive shaped variety and a great favorite for family use and home gardens, as it is very easily grown. The top is of rich scarlet from which color it shades gradually to white at the tip. It should be eaten when medium size. It is a good plan to sow at intervals of 6 or 7 days; this gives young, crisp, solid, and tender radishes throughout the season. Pkt., 5c; oz., 10c; $1 / 1$ lb., 30c; 1/2 lb., 50c; $1 \mathrm{lb} ., 90 \mathrm{c}$, postpaid.

SPARKLER (Gold Seal Quality). A splendid variety of the Scarlet Turnip White Tipped type, but showing more white, practically the whole lower part being white, while the upper half is a bright scarlet. It makes a fine show on the market bench, is very attractive and is of good quality. Pkt., 5c; oz., 15c; $1 / 41$ lb., 35c; 1 lb., 90c, postpaid.

HARTNER'S EARLY WHITE TIPPED (Gold Seal Quality), This is the little round, red radish with the white tip, that is planted in the early Spring and matures in 30 days. The flesh is snow white, crisp, and tender. For the past 12 years we have supplied and satisfied the market gardeners of this section with this special strain. They grow evenly in size and color and produce small tops. It is by far the best round, white tip radish to plant either for the market or the little home garden. If planted at intervals of 10 to 12 days you have fresh, tender radishes throughout the entire Summer. Pkt., 5c; oz., 10c; 1/4 lb., 30c; 1/2 lb., 60c; 1 lb., 90c; 5 lbs., $\$ 4.00$, postpald.

SPARKLER EARLY SCARLET TURNIP, WHITE TIPPED. One of the most attractive and popular of the early turnip sorts. The roots are slightly flattened, the upper portion a deep scarlet and the under portion white, making a beautiful contrast. Our stock of this important variety is true and can be relied on to be the best of its class. Pkt., 10c; oz., 15c; $1 / 4$ lb., 30c; lb., $90 e ; 10$ lbs., \$8.00.

HAILSTONE (Gold Seal Quality). A pure white, round radish of very fine flavor. Pkt., $10 \mathrm{c}$; oz., 15c; $1 / 4 \mathrm{lb}$, soe, postpaid.

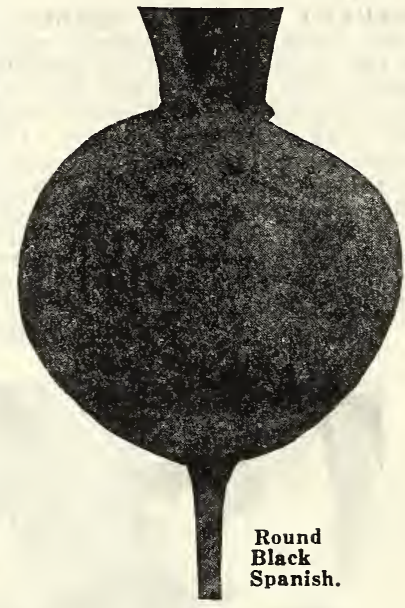

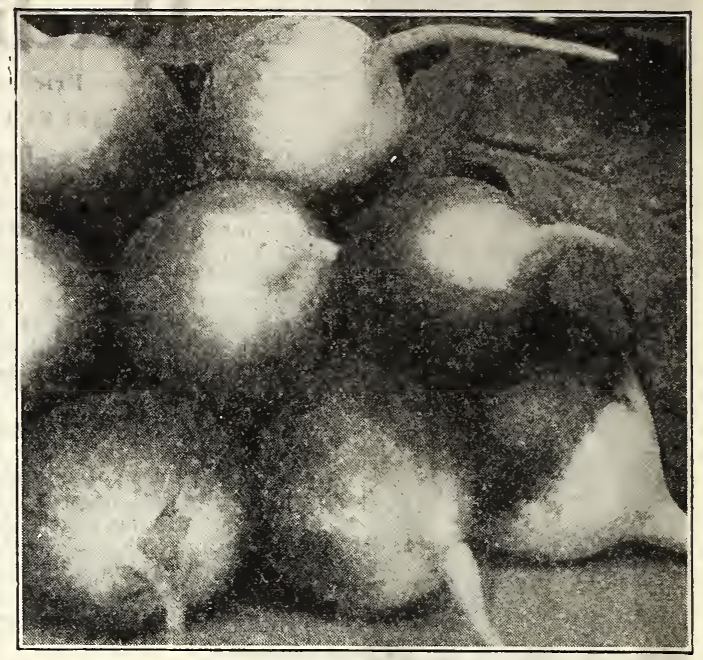

Hartner's Early White Tipped.

\section{Odd Varieties}

LONG BLACK SPANISH (Gold Seal Quality). The flavor, color of skin and flesh same as the Round Black Spanish and keeps equally well, is a long black radish instead of round. Pkt., 5c; oz, 10c; $1 / 4$ lb., 35c; $1 / 2$ lb., 60c; 1 lb., \$1.00, postpaid.

ROUND BLACK SPANISH (Gold Seal Quality). Roots round, sometimes topshaped, 3 to 4 inches in diameter, skin black, flesh white, very compact and highly flavored. Excellent sort for winter use. Pkt., 5c; 0z., 10c; 1/4 lb., 35c; 1/2 lb., 60c; 1 lb., $\$ 1.00$, postpaid.

JAPANESE WINTER RADISH (Gold Seal Quality). It resembles the Japanese Summer Radish except that it is somewhat smaller. It is more crisp and of better flavor in winter season. It is pure white, grows abcut 8 inches long and not as tapering as the larger one. Pkt., 5c; large pkt., 10 c; oz., 15c; $1 / 4$ lb., 50c: 1 lb., \$1.75, postpaid.

JAPANESE SUMMER RADISH (Gold Seal Quality). Its beautiful white color and mammoth size attract great attention. It is very tender and the flavor is excellent and mild. It attains perfection in Colorado, growing to 2 feet in length and 3 inches in diameter. It is a profitable radish to grow as it sells readily and is relished by all. We have had grown for us a limited quantity of this seed and now offer it at 5c per pkt., large pkt., 10c; oz., 15c; $1 / 4$ lb., 50c; 1 lb., $\$ 1.75$, nostpaid.

CHINA ROSE (Gold Seal Quality). This variety should not be sown earlier than the middle of June, as it is a winter variety, and if sown in the Spring it becomes too woody for use before Winter, when they are used. This radish is shorter and thicker than the Long Scarlet, and of a bright rose color. Flesh very white and solid and a good keeper. Pkt., 5c; oz., 10c; $1 / 4$ lb., 35c; $1 / 2$ lb., 60c; lb., $\$ 1.00$, postpaid.

\section{Odd Varieties}

ALL SEASON RADISH MIXTURE (Gold Seal Quality). This is a well balanced mix ture of every sort of radishes known and contains only the very best and truest strains. From a bed of our mixed radishes one can have radishes the entire season, for in mixing we include early round, early long, midseason and late varietics. It is quite interesting to have a mixed ved for you will find some sorts you never have seen before. As every seed will grow, we advise that you do not plant too thick so that each plant will thrive and have room to mature. Pkt., 5c; oz., 15c: 1/4 lb., 10c; 1 lb., $\$ 1.00$, postpaid.

\section{No Failures With Gold Seal Quality Seeds}

We wish to again call the grower's attention to the quality of the seed we offer. We do not hesitate to say that better seed cannot be offered as we are sure better seeds are not produced, and you will note our prices are very reasonable. We do very little advertising. We have the largest market garden trade in the West, which trade comes to us on account of GOLD SEAL quality and reasonable prices. 

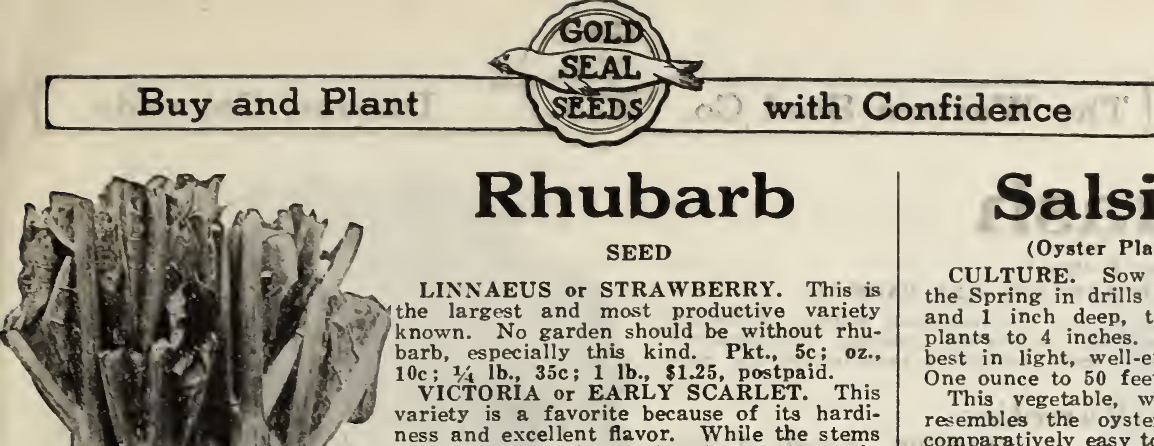

\section{Rhubarb}

SEED

LINNAEUS or STRAWBERRY. This is the largest and most productive variety known. No garden should be without rhu10 c; 1 ; lb. 35c; 1 lb., $\$ 1.25$, postpaid.

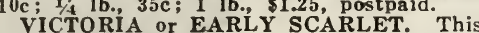
variety is a favorite because of its hardiness and excellent flavor. While the stems grow to desired length, they are rarely thicker than the thumb. It is desirable for the home garden, where good table quality is first considered. Pkt., 5c; 1 oz., 15c; $1 / 4$ lb., $40 \mathrm{c}$; 1 lb., \$1.25, postpaid.

\section{ROOTS}

We can furnish good, live roots of any of

IINNAEUS or STRAWBERRY. Large Red. VICTORIA or EARLY SCARLET. Pink, large.

Any of the above, 2 for 20c; 5 for 40c; 12 for $70 \mathrm{c}$. Charges prepaid. If by freight or express, not prepaid, 55c per doz.; $\$ 4.00$ per 100.

\section{Tobacco}

Tobacco seed must be sown early in the Spring in frames or seedbed in rich soil Reset the plants in the open ground after the weather has become warm, making space between the rows about 4 feet. The cultivation is practically the same as for corn.

MISSOURI BROAD LEAF. A well known variety of a very early kind, and one of the few that matures in our country. On account of its broad leaf, it is used by cigar makers for cigar wrappers. Pkt., 5c; 1/4 oz., 15c; 1 oz., 40c.

OONNECTICUT SEED LEAF. This is the most popular variety; can be relied on to make fine cigars. Stands the cold well. Pkt., 5c; 1/4 oz., 15c; 1 oz., 40c.
CULTURE. Sow the seed in the Spring in drills 1 foot apart and 1 inch deep, thinning out best in light, well-enriched soil. ne ounce to 50 feet of drill.

This vegetable, when cooked. comparatively easy to grow, habits similar to those of the parsimproves the quality. Can be cooked as cauliflower or sliced wor a sala

MAMMOTH SANDWICH ISmost popular sort for this sec$0 \mathrm{c} ; 1$ lb., $\$ 1.25$, postpaid.

LONG WHITE FRENCH. Pkt., $5 \mathrm{c}$; oz., 25c; 1/4 lb., $75 \mathrm{c} ; 1 \mathrm{lb}$.,
$\$ 2.50$, postpaid. nip. Can be left in the ground riety; very uniform in targest va-

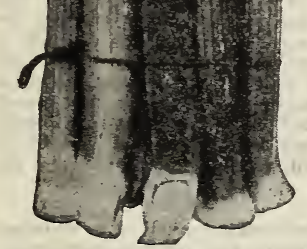

Victoria Rhubarb.

\section{Spinach}

These Prices Are Postpaid QUALITY FIRST

Uise More Spinach-It is Full of Vitamins

CULTURE. Spinach thrives in any ordinary soil and its cultivation is a very simple matter. To secure good spinach early in the Spring the seed hould be planted in the Fan. For a succession, sow again early in the Spring and every two weeks thereafter.

VIROFLAY or VERY THICK LONG-LEAVED. This is the market gardener's favorite for Fall and Spring sowing around Denver, as it furnishes an abundance of heavy, broad, dark green leaves of finest quality and appearance, and on account of their firmness and substance they remain in prime saleable condition for a long time, making it especially desirable where bulk is desired. Pkt., 5c; oz., 10c; 1/2 1b., 25c; 1 lb., 35c; 10 lbs., $\$ 2.50$.

LONG STANDING BLOOMSDALE. This variety is very desirable where a curled, dark leaf spinach is desired, which does not lay flat on the ground, for it has an upright compact growth This variety has been bred to eliminate This variety has been bred to eliminate the early seeding. It will stand ten ing. Pkt., 5c; oz., 10c; 1/4 1b., $20 \mathrm{c}$ 1 lb., $40 \mathrm{c}$; 10 lbs., $\$ 3.00$, postpaid. For larger amounts get special prices.

NOBLE GIANT-LEAVED. Thicker and larger leaves than the Viroflay which it will eventually displace, it wil produce a larger crop than any other variety. It is a quick grower but stands long before going to seed. Leaves are dark green, rounded, almost smooth and enormous in size. Pkt., 5 c 1 oz., 10c; 1 lb., 40c; 10 lbs., $\$ 3.00$, postpaid. For larger amounts get spepostpaid.
cial prices.

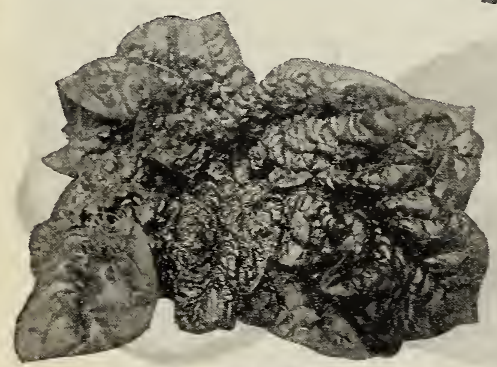

Savoy Spinach.

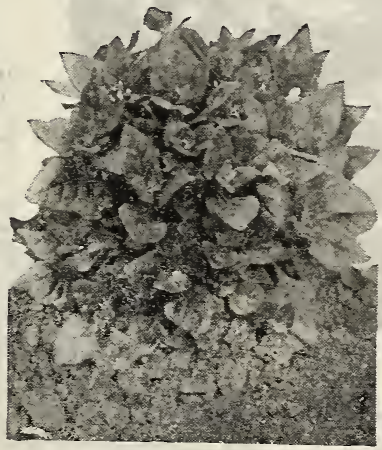

New Zealand Spinach.

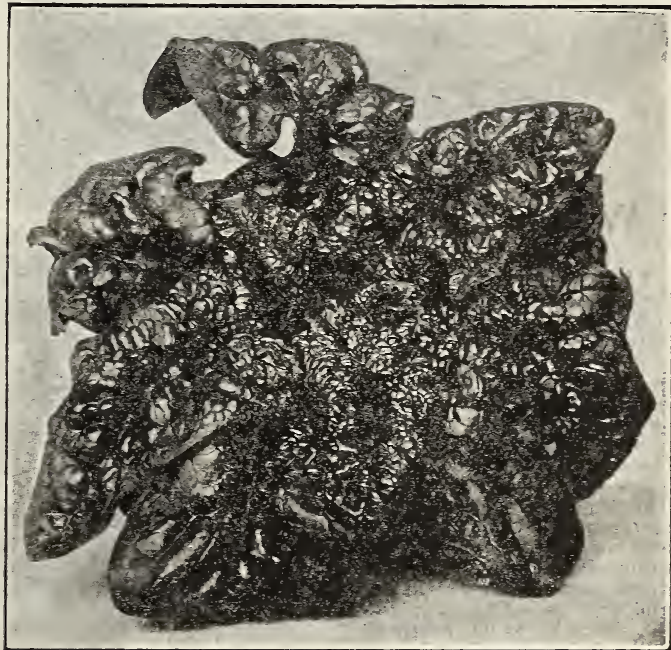

Long Standing Bloomsdale Spinach.

ROUND BROAD LEAVED. This excellent variety comes quickly to maturity, forming clusters of large, very thick leaves, rather smooth and rounded at top. A good kind and next to Viroflay as market gardeners' choice. Pkt., 5c; oz. $10 \mathrm{c} ; 1 / 2$ lb., 25c; 1 lb., 35c; 10 lbs., $\$ 2.50$, postpaid.

BLOOMSDALE SAVOY. A very early variety. The plant is of upright growth with thick, glossy, dark green leaves of medium size, pointed but quite broad, curled, and wrinkled like those of Savoy Cabbage. It is hardy and grows rapidly.
Pkt., 5c; oz., 10c; $1 / 2 \mathrm{lb}$., $25 \mathrm{c} ; 1 \mathrm{Ib} ., 35 \mathrm{c} ; 10 \mathrm{lbs} ., \$ 2.50$, postpaid. PRICKLY SEEDED WINTER. A fine variety with triangular, oblong or arrow shaped leaves. Hardiest of all ; the best for fall sowing where winters are severe. Pkt., 5c; oz., 10c; 1/2 1b., 25c: $1 \mathrm{lb.}, 40 \mathrm{c}$; 10 lbs., $\$ 2.75$, postpaid.

MOUNTAIN SPINACH. Is distinct from the common varieties and more productive. May be cut several times during a season. Produces a crop in Summer when other varieties fail. Especially recommended for home gardens, but not a commercial or market garden variety. Pkt. $10 \mathrm{c}$; $1 \mathrm{oz}$., $15 \mathrm{c}$; $1 / 4 \mathrm{lb} ., 30 \mathrm{c} ; 1 \mathrm{lb}$., $75 \mathrm{c}$, postpaid.

NEW ZEALAND (Tetragonia Expansa). Unlike true spinach in that it thrives during hot weather. The tender shoots are good quality and may be cut continuously throughout the Summer. Becomes very large and spreading; leaves small, broad, but pointed. The seed can be planted 4 to 6 inches apart or in hills. Pkt., 5c; 1 oz., 10c; 1/4 lb., 30c; 1 lb., 90c, postpaid.

KING OF DENMARK. The leaves are large, rounded, somewhat blistered, and deep green. The plants grow vigorously and are ready to use as soon as any kind; while at the same time they remain a long time in good condition after other kinds have run to seed. Pkt., 5c; oz., 10c; $1 / 4$ lb., $15 \mathrm{c} ; \mathrm{lb} ., 45 \mathrm{c} ; 10 \mathrm{lbs} ., \$ 3.50$, postpaid. 


\section{Squash}

All Prices Postpaid

FOR EARLY SQUASH USE HOTKAPS-SEE PAGE 92.

Squashes are divided into two different classes-summer and winter. Although they neither resemble nor taste alike, both are known as squashes. The majority of the summer varietis are the bush sorts, while the winter varieties are the running sorts.

\section{Summer Varieties}
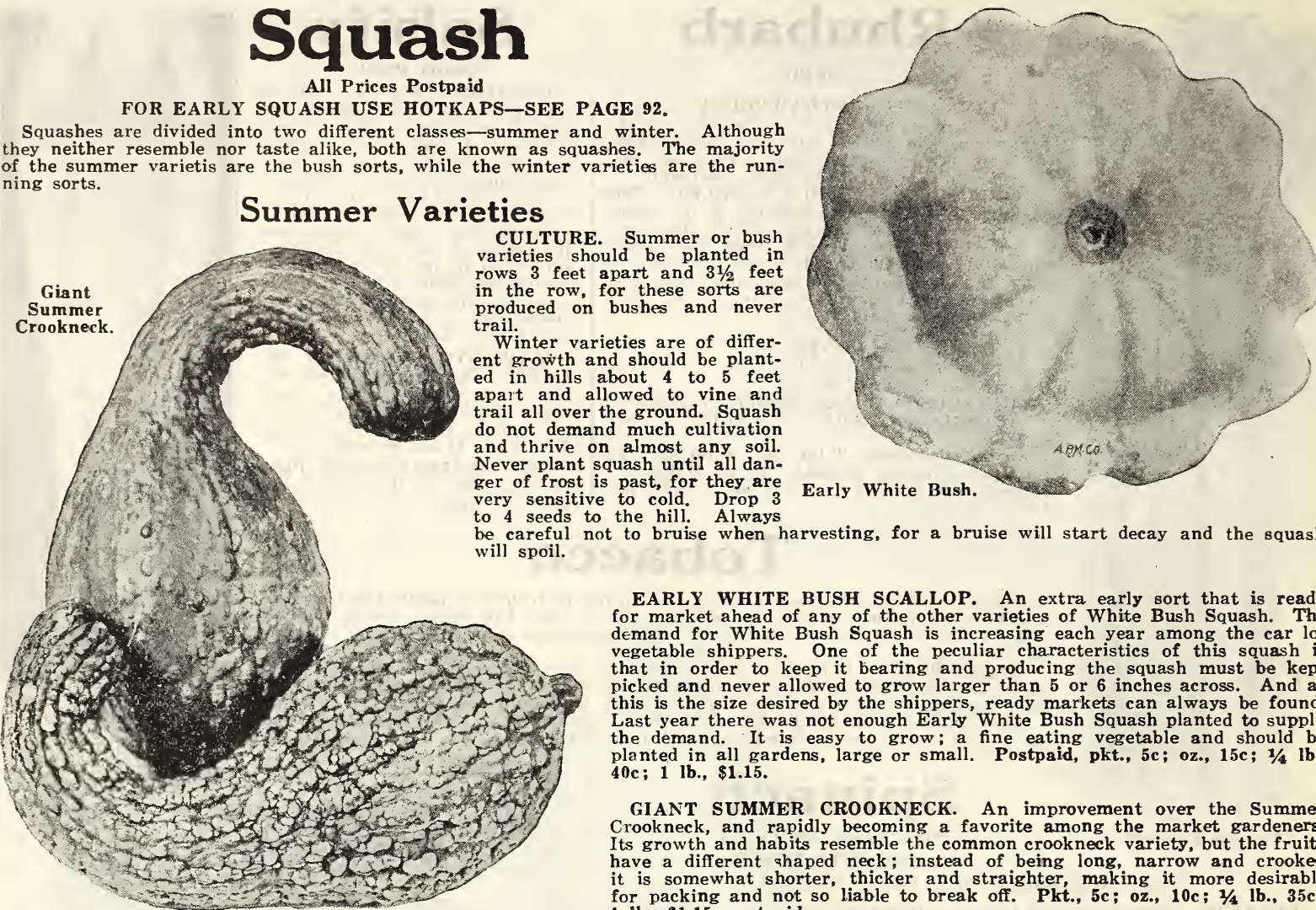

Early White Bush.

Summer or bush varieties should be planted in rows 3 feet apart and $3 \frac{1}{2}$ feet produced on bushes and never trail.

varieties are of differed in hills about 4 to 5 feet apart and allowed to vine and trail all over the ground. Squash demand much cultivation Neverive any soil. ger of frost is past, for they are very sensitive to cold. Drop 3 be careful not to bruise when harvesting, for a bruise will start decay and the squash will spoil.

\section{Winter Varieties}

CHICAGO WARTY HUBBARD. This is the best and most popular strain of the winter squash. When thoroughly ripe its tough, warted shell is as hard as a rock, and the meat is a rich golden-orange color, possessing the highest flavor, only to be compared with that of a sweet notato. Many prefer a good ripe Hubbard Squash baked well done in a hot oven to baked sweet potatoes. Chicago Warty Hubbard, if allowed to ripen will keep in good condition, and one may have this delicious vegetable all Winter. They are easy to grow, and pay you well for the time and trouble. Pkt., 5c; oz. 15c; 1/4 lb., $40 \mathrm{c}$; lb., $\$ 1.00$, postpaid.

EARLY WHITE BUSH SCALLOP. An extra early sort that is ready for market ahead of any of the other varieties of White Bush Squash. The demand for White Bush Squash is increasing each year among the car lot vetable shippers vegetable shippers. that in order to keep it bearing and producing the squash must be kept picked and never allowed to grow larger than 5 or 6 inches across. And as this is the size desired by the shippers, ready markets can always be found. the demand. It is easy to grow; a fine eating vegetable and should be planted in all gardens, large or small. Postpaid, pkt., 5c; oz., 15c; 1/4 lb., 40c; 1 lb., \$1.15.

GIANT SUMMER CROOKNECK. An improvement over the Summer Crookneck and rapidly becoming a favorite among the market gardeners. Its growth and habits resemble the common crookneck variety, but the fruits have a different shaped neck; instead of being long, narrow and crooked it is somewhat shorter, thicker and straighter, making it more desirable for packing and not so liable to break off. Pkt., 5c; oz., 10c; $1 / 4 \mathrm{lb} ., 35 \mathrm{c}$; 1 lb., $\$ 1.15$, postpaid.

GOLDEN HUBBARD. Very productive; fruits uniform in size, weighing from 6 to 8 pounds. Shaped like the Hubbard; good keeper; shell is very hard, warty and of rich orange-red color.
Pkt., 5c; oz.. 15c: $1 / 4$ lb., 40c; 1 lb., $\$ 1.25$, postpaid.

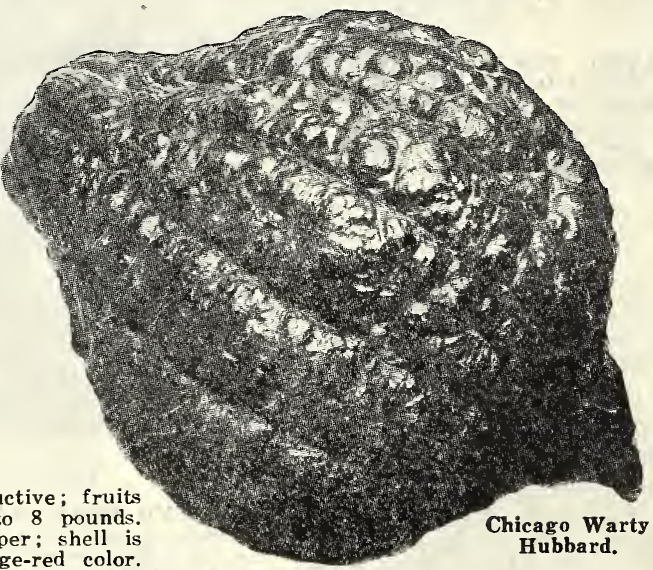

VEGETABLE MARROW. Any one enjoying summer varieties should plant some of this variety as it is exceedingly delicious as well as prolific. Steamed when young or can be fried as an eggplant and is equal to eggplant. The squash is 12 to 14 inches in length, is a creamy color, does not rein length, is a creamy color, does not regood sort for dry lands. Pkt., 5c; oz., 10c; $1 / 4$ lb., 35c; 1 lb., \$1.15, postpaid.

\section{Acorn Squash}

This squash is sometimes called the Des Moines or Individual, and is a small acorn shaped squash with dark green rind and is a very choice squash for serving individually by cutting it open lengthwise from stem to blossom end, and after scraping out the seed cavity and placing a large lump of butter in the one half, place the two halve back together and bake them and serve in the shell. Pkt., 10c; oz., 20c; $1 / 4$ lb., 50c: $1 \mathrm{lb}$., $\$ 1.50$.

HUBBARD SQUASH (TRUE). The old standard variety of winter squash, and equal in every respect to the warty in growth, flavor and yield, but matures a few days earlier. Practically the only difference is in the skin or shell. The true Hubbard has a smooth surface while the warty Hubbard is knotted and rough. Price, postpaid: Pkt., 5c; oz., 15c; 1/4 lb., 40c; 1 lb., \$1.00.

PIKE'S PEAK or SIBLEY. An excellent winter squash. Fine grained and superior in flavor and keeping qualities to the Hubbard squash, but not so well known. Pkt., 5c; 0z., 15c; $1 / 4$ lb., 40c; 1 lb., \$1.25.

BOSTON MARROW. Is the favorite winter squash of the Eastern states. It is of fine flavor and a good keeper. Pkt., $5 \mathrm{c}$; oz., $10 \mathrm{c} ; 1 / 4 \mathrm{lb} ., 35 \mathrm{c} ; 1 \mathrm{lb}$., $\$ 1.00$. MARBLE HEAD. Of bluish color, sweet and dry. Fine flavored. Shape long and pointed at both ends. Pkt., 5c; oz., 15c; 1/4 lb., 40c; $1 \mathrm{lb}$., $\$ 1.25$.

DELICIOUS. This is a splendid variety; more like the Hubbard than any other, but surpasses it in some respects for home use as it is not quite so large. The shell is not so hard; the meat is thicker and of extra fine quality. Pkt., 5c; oz., 15c; $1 / 4$ lb., 40c; 1 lb., \$1.25.

BANANA SQUASH. This is a rather odd squash but a great favorite wherever grown. The squash grows $11 /$ to $21 /$ feet long and about 9 inches in diameter. The skin is light olive color; flesh beautiful orange and it is recognized as the sweetest squash that grows. When matured it will keep longer than the Hubbard. Pkt.. 5c; oz., 20c; $1 / 41$ lb., 50c; 1 lb., $\$ 1.50$.

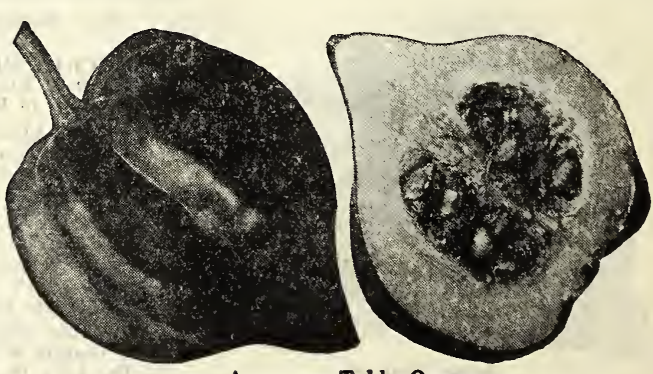

Acorn or Table Queen. 


\section{Tomatoes-Western Grown}

Prices on Tomatoes Are Postpaid

CULTURE. The best crops are grown in light soil. For extra early fruit the seed should be sown in hotbeds abuut the first week in March. Sow seed in rows 4 inches apart and nut over one-half inch deep. Enough plants for a small garden may be grown in shallow boxes or flower pots in a sunny window in the house. When the weather become. warm out-of-doors, gradually harden them by exposing them to the air. When all danger of frost is past, sel olit in the open and water until the plants are established.

BEAUTY (Gold Seal Quality). A hardy grower, very prolific ; large, smooth and a glossy crimson with a tinge of purple; grows in clusters of four to six large fruits, retaining it splendid size thrcughout the entire season. Ripens quite early; flesh is very fiım, has a tough skin and few seeds, seldom rots or cracks after rain. Picked green, it will still ripen nicely. For the main erop we strongly recommend the Beauty, as for shipping and general marketing purposes it has no superior. Our seed is grown from selected stock and has been tested. It can be depended upon to give the best results. Pkt., 5c; $1 / 4$ oz., $10 \mathrm{c}$; oz., $35 \mathrm{c} ; 1 / 4 \mathrm{lb}$., 90c; 1 lb., $\$ 3.00$, pcstpaid.

MARGLOBE. The most important Tomato introduced in years-the achievement of Dr. Fred Pritchard, U. S. Department of Agriculture. It is practically immune to Nail Head Rust and Fusarium Wilt. It is a hybrid from Malvel and Globe, of pure scarlet globe shaped type, having the fine characteristics of the Globe but more vigorous; heavier producer and somewhat earlier-an exceptionally fine Tomato especially recommended for shipping. Price, pkt., $10 \mathrm{c} ; 1 / 2$ oz., $30 \mathrm{c} ; 1 / 41 \mathrm{~b} ., \$ 1.75 ; 1 \mathrm{lb} ., \$ 5.50$.

THE WYOMING TOMATO. Is more prolific than the Beauty, stands shipping better, is more unifolm in size and free from cracks and cat faces. It bears medium size fruit in clusters of four or fve round, solid Tomatoes, colored purplish pink. This variety has been thoroughly tried by us and we highly recommend it to growers who raise Tomatoes for market and shipping trade. Pkt., 15c; oz., 35c; 1/4 lb., $\$ 1.00$ lb. $\$ 3.50$.

JUNE PINK (Gold Sea) Quality). One of the most satisfactory, extra early varieties, yields as much as Spark', Earliana and Chalk's Early carly Jewel, ripening a few days earlier than either of these. The fruit is good size, smooth, purplish red and ar produced in great abundance. This is an excellent tomato for the home garden or loca market, but will not stand shipping, as it is too tender and thin-skinned for this purpose Pkt., 5c; large pkt. $10 \mathrm{c}, 1 / 4,15 \mathrm{c}, \mathrm{cos}$ $1 / 4$ lb., $\$ 1.50 ; 1$ lb., $\$ 5.00$ postpaid.

JOHN BAER (Gold Seal Quality). The John Baer is

the largest extra early tomato grown. It is a very vigorous grower and sets its blossoms quicker than any of the early sorts. It does not make long vines, but covers the short stalky vines with an abundance of large size, globular, smooth, and uniform with an abundance of large and are ready for the market one tomatoes that ripen ouick and are ready for the market one week earlier than the Earliana. The color is a beautiful bright scarlet. The fruit is coreless and has a delicious sweet flavor, being very solid and me

BONNY BEST. An early scarlet fruited tomato which has BONNY BEST. An early scarlet fruited tomato which has proven very successful wherever grown. It matures about ten days earlier than the Chalk's Jewel, is smooth, very even in home garden, canning, and shipping purposes. Pkt., 10c; oz., $40 \mathrm{c}$; $1 / 4$ lb., $\$ 1.30$; $1 \mathrm{lb} ., \$ 4.00$, postpaid.

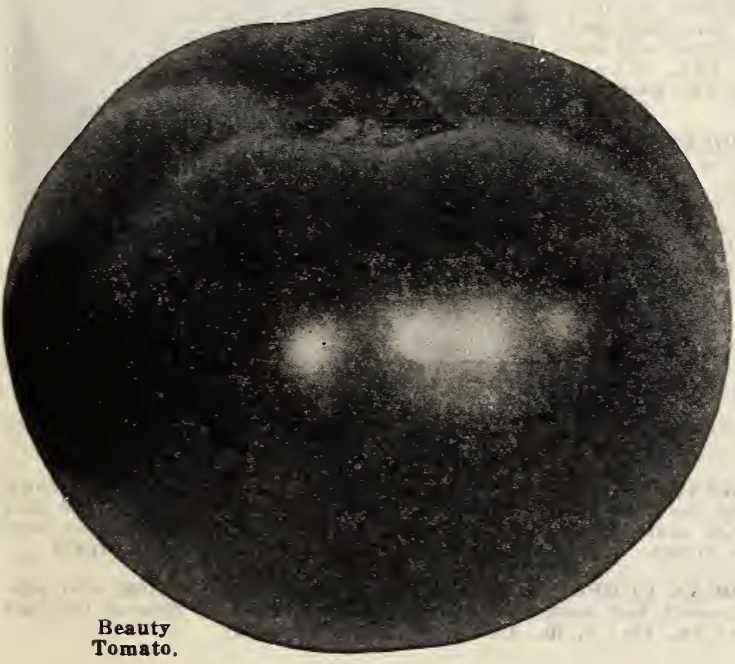

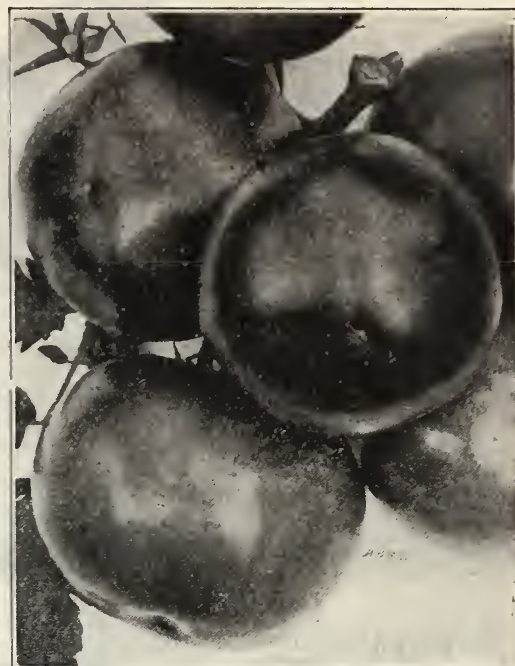

June Pink.

CHALK'S EARLY JEWEL. This is one of the most satisfactory of all early varieties, matures a week to ten days later than the Earliana. The fruit is bright red, very heavy, producing abundantly and continually, hav abundantly and continually, having an excellent flavor. One of the finest for the home garden
and for canning. Pkt., 5c; $1 / 4$ oz.. $10 \mathrm{c}$; oz., $35 \mathrm{c}$; $1 / 4$ lb., $\$ 1.25$; 1 lb., $\$ 4.00$.

EARLY BIRD (Gold Seal Quality). This new, extra early tomato is the leading early variety. Its color is dark red, it is of dwarf habit, bears large fruit, and is a heavy producer. Pkt., $\$ 4.00$, postpaid. fruit is produced in clusters of three to five; having a glossy purple appearance, and are very solid, meaty, and thick fleshed. The plants make a sturdy, upright growth and are frequently called Tree Tomatoes. Pkt., 5c; 1/4 0z., 15c; 0z., 40c; 1/4 lb., $\$ 1.25 ; 1$ lb., $\$ 4.00$, postpaid.

PONDEROSA (Improved Strain). Is a purple Tomato, a little late. It is the largest and heaviest practical variety; bears well throughout the entire season and is a fine sort for the home garden. Pkt., 5c: $1 / 4$ oz., 20c; 1 oz., 50c; $1 / 4$ lb., $\$ 1.75 ; 1$ lb., $\$ 5.50$, postpaid

EARLY DETROIT. A second early, medium sized, smooth, handsome, globe-shaped, purple fruited variety. Yields heavier and earlier than Beauty, which it closely resembles. Considered a better main crop tomato than Beauty, being more prolific thicker, and a better shipper. Pkt., 10c; 02., 50c; $1 / 4$ lb., $\$ 1.60 ; 1$ lb., $\$ 5.50$, postpaid.

ACME TOMATO. Vines are large, hardy, and productive. Fruits are purplish nink, round, smooth, and of a medium size, free from cracks. Although a very good shipping variety, it is also desirable as a home garden sort. Pkt., 10c; oz., 50c; 1/4 lb., $\$ 1.50 ; 1$ lb., $\$ 5.00$.

SPARKS' EARLIANA. A remarkably early tomato. Fruit of good size, red, smooth, and a very heavy yielder. Recommended as an early tomato, but not for main crop. Pkt., 5c; oz., 30c; $1 / 4$ lb., $90 \mathrm{c} ; 1$ lb., $\$ 3.00$. NEW STONE. It is a sure cropper; fruit smooth, larger and more prolific than the Beauty and the flesh is solid and free from core. Pkt. $5 \mathrm{c} ; 1 / 4$ oz., $15 \mathrm{c}$; 0z., 35c: $1 / 4 \mathrm{lb} ., \$ 1.00 ; 1 \mathrm{lb} ., \$ 3.00$.

GLOBE. A beautiful early variety. Has firm flesh, few seeds, ripens early, is very productive and almost blight proof. This tornato should be planted more extensively by out-of-door planters for it is early and an abundant producer, of fine flavor and an excellent shipper. As a greenhouse tomato it is absolutely unexcelled. Pkt., 5c; oz., 40c; 1/4 lb., $\$ 1.25 ; 1$ lb., $\$ 4.00$.

\section{Small Varieties for Preserving and Pickling}

YELLOW PLUM. Yellow, plum-shaped, average one inch in diameter; excellent flavor. Pkt., 5c; $1 / 4 \mathrm{oz} ., 15 \mathrm{c} ; 1 \mathrm{oz} ., 50 \mathrm{c} ; 1 / 4 \mathrm{lb} ., \$ 1.75$.

YELLOW PFAR. Similar to the Yellow Plum, but fruits are pearshaped. Pkt., 5c; $1 / 4$ oz., $15 \mathrm{c} ; 1$ oz., $50 \mathrm{c}$; $1 / 4 \mathrm{lb} ., \$ 1.75$.

RED CHERRY. Fruits round, bright red, presenting a beautiful appearance. Pkt., 5c; $1 / 4$ oz., 15c; 1 oz., 50c; 1/4 lb., \$1.75.

HUSK TOMATO. For preserving purposes only. Pkt., 5c; $1 / 4$ oz., $15 \mathrm{c} ; 1$ oz., $50 \mathrm{c} ; 1 / 1 \mathrm{lb.}$. $\$ 1.75$.

MIXED SMALL TOMATOES. Above four varieties. Pkt., 10c. 


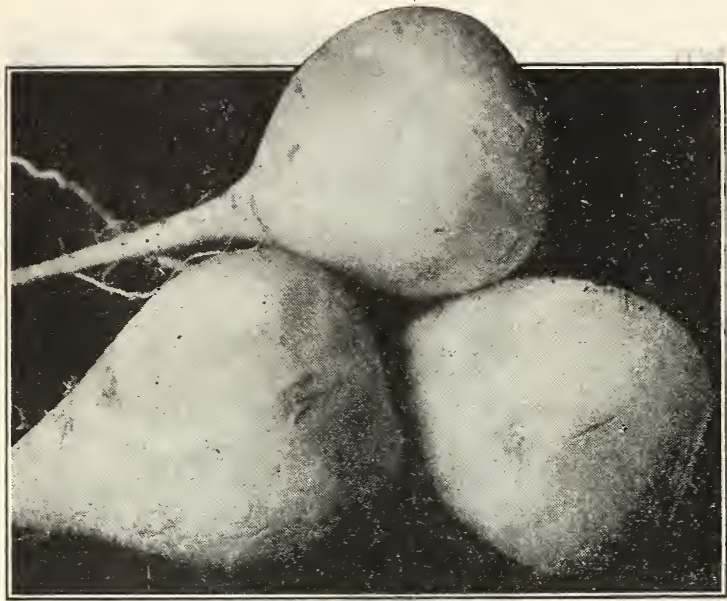

Gold Seal White Egg.

EXTRA EARLY WHITE MILAN (Gold Seal Quality). This is the earliest turnip and is grown exclusively for bunching for the early market. A flat variety, and for this reason has practically no sale after the practically no sale after the plobe haped. Pkt., 5c; large pkt., loc; $0 z$. . postpaid.

EARLY SNOWBALL. Very rapid grower, being white, and is the first of the globe-shaped sorts. Pkt., 5c; 0z., 10c; 1/4 lb. $35 \mathrm{c} ; 1 \mathrm{lb} ., 90 \mathrm{c}$, postpaid.

EARLY PURPLE TOP MILAN (Gold Seal Quality). Same as Extra Early White Milan ex cept that about one-third of the turnip is a purplish blue. Pkt. $5 \mathrm{c}$; large pkt., $10 \mathrm{c}$; oz., 15c;
$1 / 41 \mathrm{~b} ., 40 \mathrm{c} ; 1 \mathrm{lb} ., \$ 1.25$, postpaid.

LONG WHITE or COW HORN. This variety grows large, partly above the ground. Flesh white and sweet. Pkt., 5c; oz., 10c; 1/4 lb., 30c; $1 \mathrm{lb} ., 90 \mathrm{c}$, postpaid.

POMERANIAN WHITE GLOBE. One of the most productive kinds and in good rich soil, roots will frequently grow eight pounds in weight. Perfect globe shaped; skin white and smooth. Pkt., 5c; oz., 10c; $1 / 4$ lb., 30c; 1 lb., 90c.

\section{Turnips}

CULTURE. Turnip is one of the first seeds to be sown in the Spring. As soon as the ground can be worked, spade or plow deeply, and prepare the surface finely, raking off all clods and stones. Sow the seeds at once in the freshly dug soil : sow very thinly and rake the seeds into the soil one-half inch deep. When up, thin out to three inches apart. Turnips become tough and strong during the hot weather, and the sowing should be so regulated that they will become fit for use, either early in the Summer or late Autumn. For winter use, sow from the middle the end of August.

PURPIE TOP WHITE GLOBE (Gold Seal Quality). The most popular turnip in cultivation, possessing the two qualities looked forward to from turnips; being both early and sweet. The demand for the Purple Top turnip is becoming greater each year, and in a short time it will be classed among the leading turnips for market gardeners. The flesh is snow white, crisp, sweet, and solid; skin is pure white and smooth except at the crown and shoulders of the turnip; it is colored a rich, reddish purple. A good keeper. Pkt., 5c; oz., 10c; 1/4 lb., 30c; 1 lb., 90c, postpaid.

WHITE EGG ("Gold Seal")-This strain of White Egg turnip is the standard for market gardeners who plant for sacking purposes. It is an unusually quick grower and never fails to produce even size, pure white turnips of perfect shape. After you have harvested your crop of early peas, beans, cabbage, lettuce, etc., you will have plenty of time to secure a good crop of turnips of this strain from the same piece of ground. The skin and meat are as white as snow, being very crisp, tender and sweet, and it is known as the best turnip for keeping or storing throughout the Winter. Due to its sweet fla vor it is regarded as the finest eating turnip under cultivation. Price, pkt., 5c; 1 oz., $10 \mathrm{c} ; 1 / 4 \mathrm{lb}$. $30 \mathrm{c} ; 1$ lb., $90 \mathrm{c}$, postpaid.

EARLY PURPLE TOP STRAP LEAF. This is a flat shaped turnip-one-third of the upper portion is purple, balance of the skin is white. In many localities this variety is preferred on account of its fine flavor and it finds a place in many home gardens. It is not extensively planted by market gardeners. Pkt., 5c; 0z., 10c; $1 / 4$ lb., 30c: 1 lb., 90c, postpaid.

Extra Early White Milan.

(1)

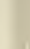

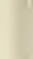




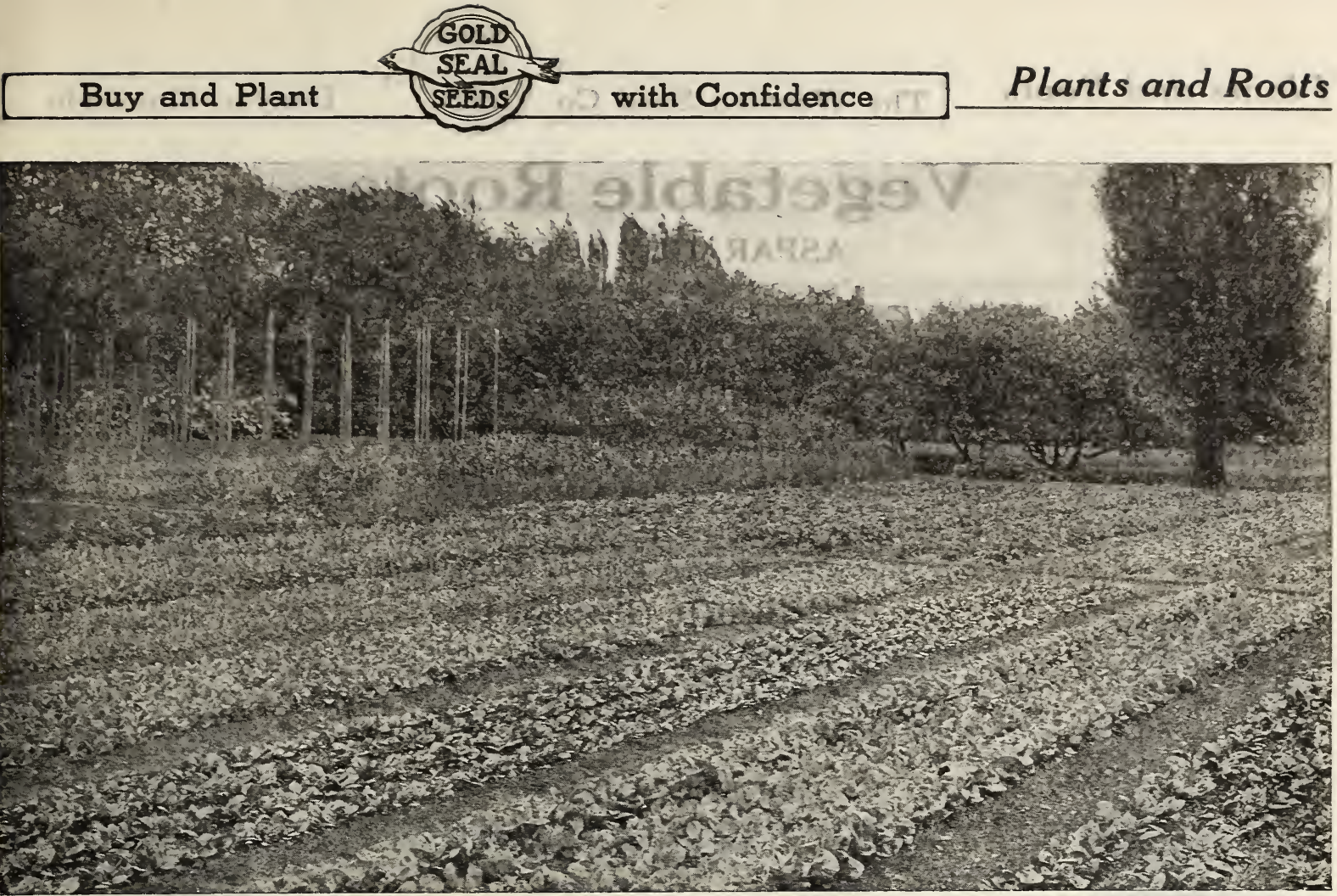

\section{Vegetable Plants and Roots}

CABBAGE, Early. Golden Acre $\begin{array}{ccc}\text { Doz. } & 100 & 1000\end{array}$

CABBAGE, Early. Early Jersey Wakefield, Charleston Wakefield, Copenhagen Market, Glory of Enkhuizen, Winnigstadt (Ready April 15th)

CABBAGE, Late. Hollander, Danish Roundhead, Danish Ballhead, Evergreen Hollander, Flat Dutch (Ready May 1st or later if desired)

CABBAGE, Red. Red Rock, Red Stonehead (Ready April 15th or later)

CABBAGE. Savoy or Curly, Early Ulm, Drumhead Savoy (Ready April 15th or later)

EGGPLANT. Black Beauty, New York Improved (Ready May 20th

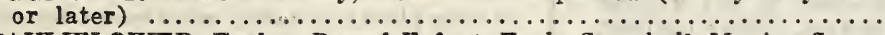

CAULIFLOWER, Early. Dwarf Erfurt, Early Snowball, Maxine Snow-

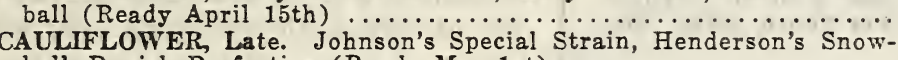

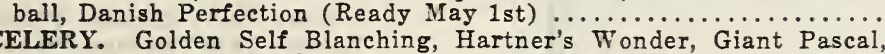
Golden Summer (Ready May 20 th or later) .................

CELERY. Hartner's Country Club (Ready June 5th or later) .......

TOMATOES, Transplanted. Early Bird, June Pink, Earliana, Chalk's

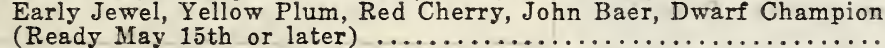
PEPPERS. Chinese Giant, Early Neapolitan, Pimiento, Bull Nose,

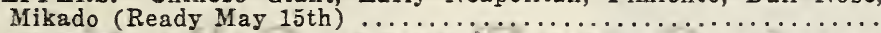
PEPPERS, Chili, Cayenne, Ruby King, Ruby Giant, (ready Mas 15 th

\section{Onion Plants}

These plants are field grown, which makes them very hardy; however, all plants deteriorate more or less and in order to save time and have them arrive in the best possible condition, we fill all large orders for a crate or more direct from the growers. For less amounts, we supply from stock which we carry at Denver. These plants are put up 100 in a bunch or 6000 in a crate. We will be glad to supply any amount.

Prices by Parcel Post, Prepaid $\quad 100 \quad 1000 \begin{gathered}\text { Crate of } \\ 6000\end{gathered}$ Sweet Spanish ..............\$0.40 \$2.00 \$8.50

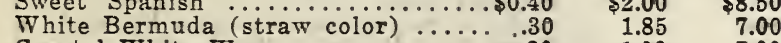
Crystal White Wax ..................... $\quad 1.90 \quad \mathbf{7 0}$

The above prices are delivered anywhere in the United States except Utah, Montana, Nevada, and Wyoming, where an extra charge of $90 \mathrm{c}$ per crate will be made.

$\begin{array}{rrr}.20 & .70 & 4.50 \\ .20 & .70 & 4.00 \\ 20 & .70 & 4.50 \\ .20 & .70 & 4.50 \\ .40 & 1.50 & 10.00 \\ .25 & 1.00 & 6.50 \\ .25 & 1.00 & 6.50 \\ .20 & .65 & 4.00 \\ .25 & .80 & 5.00 \\ .30 & 1.00 & 6.50 \\ .30 & 1.50 & 8.00 \\ .30 & 1.50 & 8.00\end{array}$




\title{
Vegetable Roots
}
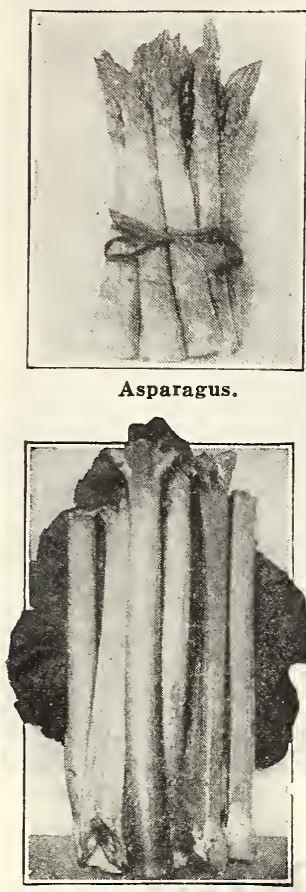

Rhubarb.

\section{ASPARAGUS ROOTS}

The roots we offer are fresh stock grown from our best strains of imported seeds. We offer both one-year and two-year-old roots, but for good quick results we recommend the two-year-old strong, vigorous roots. The prices on asparagus roots are postpaid. The two best varieties grown in our section are the Palmetto and the Argenteuil; both produce green shoots that are tender from tips to base. We can furnish good, strong plants of the following: Giant Argenteuil, Palmetto, Conover's Colossal, Mamnioth White. Good two-year-old roots, 1 dozen, 35c, postpaid; 100 for $\$ 1.50$, postpaid; 1000 for $\$ 10.00$, not prepaid.

MARY WASHINGTON. This asparagus, which has been selected by the United States Department of Agriculture, Washington, D. C., has proven to be nearly rust free. The shoots are thick and heavy. They are long and straight with closely folded tips. The color is rich dark green, tinted darker at the tips. It is a heavy yielder of exceptionally fine flavor. 1 dozen, $40 \mathrm{c} ; 100, \$ 2.00$, postpaid; $1000, \$ 12.00$, not prepaid.

\section{RHUBARB (Pieplant)}

No garden is complete without this old standard. It is easy to start and improves each year. Although we have many varieties we recommend the Strawberry, Giant Red, Large Victoria. We have only twoyear-old roots that will do well in any soil. Each, 10c; dozen, 70c, postpaid; $100, \$ 3.75$, not prepaid. Write for special price on large amounts.

\section{HORSERADISH}

This is one of the hardiest vegetables for the garden or farm. It gives results the first year. The larger roots can be taken up and stored for winter use. If grown for the market you will find it very profitable. 1 dozen roots postpaid, 20c; 100 roots postpaid, \$1.25. For larger amounts get our special price.

\section{JERUSALEM ARTICHOKES}

The culture of the artichoke is similar to the potato, hence the name: "Potato Artichokes." For description see page 57. Price, 1 lb., postpaid, $15 \mathrm{c} ; 10 \mathrm{lbs}$., postpaid, 90c. Write for prices on large amounts.

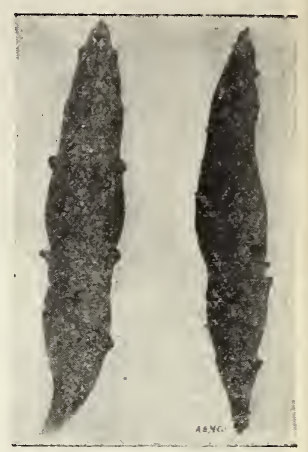

Jerusalem Artichokes.

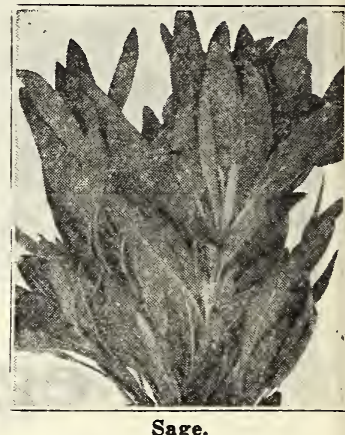

\section{MINT ROOTS}

The true old-fashioned mint for seasoning; easy to grow and gives results the first season. Dozen, 15c; clump of roots, $30 \mathrm{c}$, postpaid.

\section{CHIVES (Schnittlauch)}

Although of the vegetable family it can also be used as a border plant for the flowers. For flavoring soups, cottage cheese, etc. When using for flavoring the tall slender leaves or tops are clipped close to the ground and chopped up fine, the same as parsley. After cutting, the tops sprout again for future use; 8 or 10 cuttings may be obtained in one season. Per bunch, large, 30c, prepaid.

SAGE

One-year clumps. Each, 30c, postpaid.

\section{TARRAGON}

Highly reeommended for Tarragon vinegar. Each, 15c, postpaid.

\section{Vegetable Plant Collection 60c Postpaid}

We are offering you here a fine collection of good strong plants, a dandy assortment for an average garden. Extra care is given this collection, both as to the grade and packing, so that they will carry well by mail.
1 dozen Early Cabbage Plants.
1 dozen Late Cabbage Plants.
$1 / 2$ dozen Large Green Pepper Plants.
1 dozen Snowball Cauliflower Plants.
$1 / 2$ dozen Large Tomato Plants.

\section{Our Easy to Grow Flower Collection}

\author{
Sent prepaid to your door by mail
for $\ldots \ldots \ldots \ldots \ldots \ldots \ldots \ldots \ldots \ldots \ldots \ldots \ldots \ldots \ldots \ldots \ldots \ldots \ldots$ \\ Regular selling price of this selection is $90 \mathrm{c}$.
}

1 Pkt. Grandiflora Sweet Peas.

1 Pkt. Large Flowering Mixed Petunia.

1 Pkt. Dwarf Mixed Nasturtiums.
1 Pkt. Grandiflora Mixed Salpiglossis.

1 Pkt. Cosmos.

1 Pkt. Sweet Alyssum.

1 Pkt. Mixed Zinnias.

\section{Flowering Annuals Collection}

Alyssum, Little Gem Balsam, Defiance Mixed Calendula, Lemon Queen Calliopsis, Drummondi Centaurea Cyanus, Double Mixed Clarkia. Finest Mixed

\section{Pkt. Each}

Cosmos, Early Flowering Mixed

Dianthus, Fordhook Favorites

Eschscholtzia, Mixed

Marigold, Tall Double Mixed

Marvel of Peru, Mixed

Nasturtium, Dwarf
Pkt. Dwarf French Marigold.

Pkt. Large Flowering Diummondi Phlox

Pkt. Morning Glory, Mixed.

\section{Our special price, $\ldots \ldots \ldots \ldots . \ldots 1.00$
prepaid $\ldots \ldots \ldots \ldots \ldots \ldots$}

If packed sevarately this collection would cost $\$ 1.75$.

Phlox

Poppy

Mourning Bride

Sunflower Double Chrysanthemum Flowered

Zinnia, Giant Mammoth, Mixed

Strawflower 


\section{Western Seed Collections}

These collections of seed, which we offer at half price, include only the best varieties of their kind and represent many high-priced novelties. The only cheap item about them is the price. It is possible for us to sell these collections at this price for two reasons; we get them ready before the Spring rush opens, when our time is less valuable; secend, in making this offer, it helps us get acquainted with many

NOTICE-These collections are already put up and we cannot change any of the varieties

\section{FARM GARDEN COLLECTION $\$ 3.00$}

This Complete Collection for $\$ 3.00$; Regular Price, $\$ 5.35$.

This Complete Collection for $\$ 3.00$; Regular Price, $\$ 3.35$.

44 lb. Egyptian Beet ....................................

lb. Chantenay Carrot

lb. Yellow Danvers Onion

i lb. Alaska Peas

1 lb. Late Strategem Peas

1 lb. Golden Wax Beans

4 lb. Early Sweet Corn

4 lb. Late Evergreen

lb. Long Radish

i. lb. Grand Rapids Lettuce.

i lb. Kleckley Sweet Watermelon

$1 / \mathrm{lb}$. Rocky Ford Cantaloupe

2 qt. Yellow Onion Sets

\section{MOUNTAIN VEGETABLE COL- LECTION, 70c}

We find that mountain grown vegetables are far superior in We find that mountain grown vetables are far superior in quality to those grown elsewhere, therefore everybody living in the mountains should raise at least enough vegetables for their own use. Many sorts of vegetables will not grow in high altitudes. We have made up a collection that

offer a $\$ 1.15$ collection for $70 \mathrm{c}$,

Mountain Iceberg Lettuce

Early Beets

Half Long Carrots

Green Beans

Telephone Peas

White Tip Round Radishe

White Egg Turnips

1 Qt. Yellow Onion Sets

Bangholm Rutabagas

\section{GARDEN SEED COLLECTION, \$1.50}

Below we have made up a collection of Garden Seeds which is very valuable, especially for beginners. This collection at regular price amounts to $\$ 2.50$. We will send it postpaid for $\$ 1.50$.

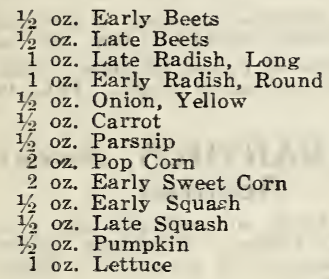

oz. Late Squash

1 oz. Lettuce

2 oz. Early P.eas

2 oz. Late Peas

2 oz. Wax Beans

oz. Green Podded Beans

2 oz. Pole Beans

1 pkt. Tornato

1 pkt. Cucumber

1 pkt. Waterm

1 pkt. Turnip

1 pkt. Larly Cabbage

1 pkt. Muskmelon

1. 3 oz. Salsify

\section{OUR GREAT \$1.00 WESTERN SEED COLLECTION}

30 full sized packages which sell at $5 c$ and $10 c$ each, for $\$ 1$

Beans, Golden Wax Beans, Shippers Green Beets, Detroit Dark Red Cabbage, Early Wakefield Cabbage, Late Holland Cantaloupe, Rocky Ford Carrot, Chantenay

Carrot, Oxheart

Corn, Early Evergreen Corn, Howling Mob (New Strain

Cucumber, Long Green Lettuce, Grand Rapids Lettuce, Big Boston (head) Lettuce, Prize Head Morning Glory (Finest Mixed)

Nasturtium, Dwarf (Finest
Mixed)
Onion, Yellow Globe Danvers
Onion, Red Globe
Oyster Plant, Mammoth
Sandwich Island
Parsnip, Hollow Crown
Peas, American Wonder
Pumpkin, Small Sugar
Radish, Early Long Scarlet
Radish, White Tip Scarlet
Squash, The Hubbard
Squash, White Bush Scallop
Sweet Peas, Spencer Mixed
Tomato, Livingston Beauty
Turnip, Snowball
Watermelon, Rocky Ford

\section{Read About} Our Free Offer See Page 58

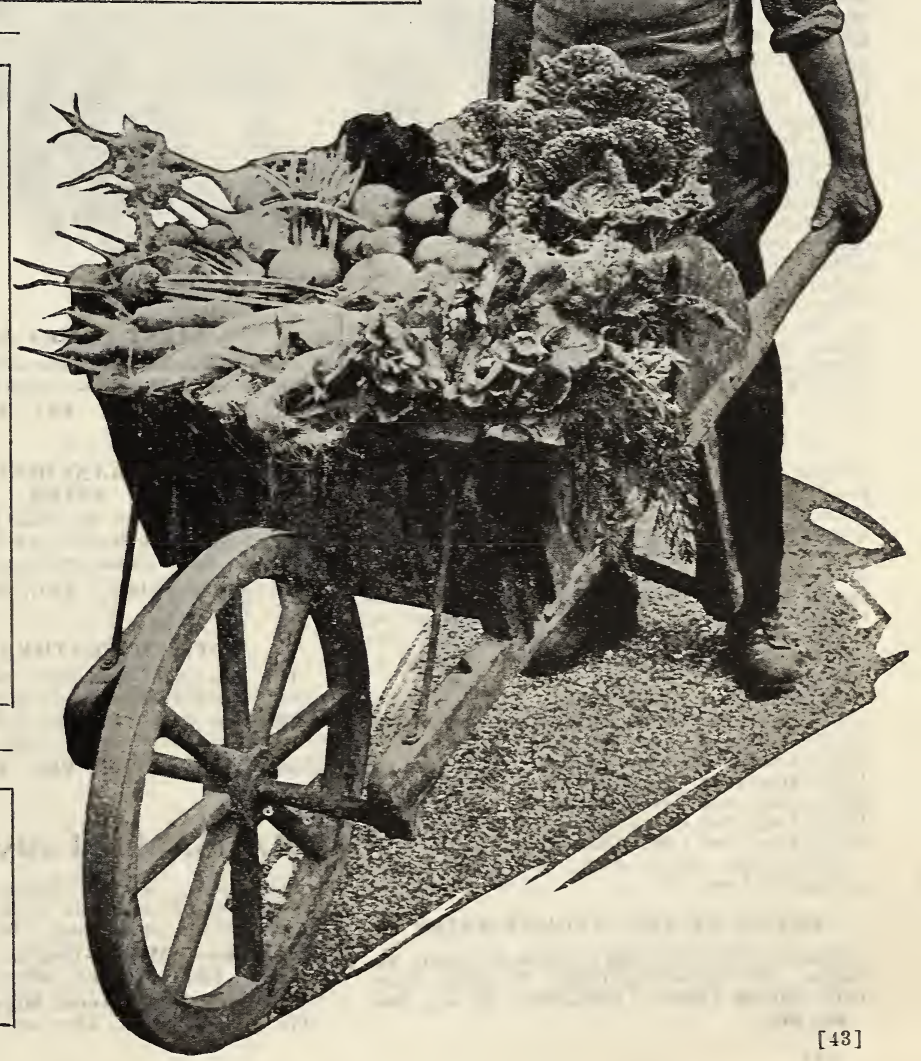




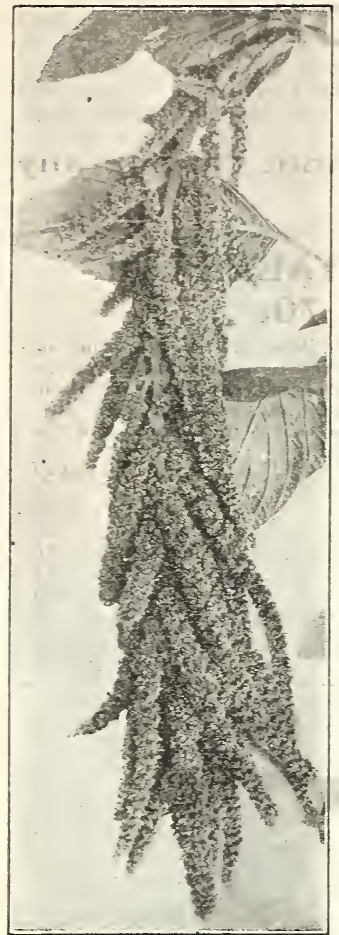

Amaranthus Caudatus.

\section{ASTERS}

The asters are now amung the most interesting, beautiful and satisfactory of flowers; late years have added charming new colors and gigantic size to the kinds now being grown in this country. They thrive and Summer and there is hardly a prettier sight than a bed of asters in full bloom. They will do well in a partly shaded position where their blos. soms last longer and attain a deeper tint than in full sunshine. The aster is of easy culture and when started from in theed should be sown in March or Apri in the hotbed, greenhouse, or in boxes, and when the plants have three or four leaves way. For aster plants, see page 66 .

\section{IMPROVED CREGO ASTERS}

This class of asters are so unique that we feel they should have a section all to themselves. Of free, sturdy growth, attaining a height of 2 to $21 \frac{1}{2}$ feet. The foliage is a glossy green, the branches bearing literally in masses the most graceful fluffy flowers, rarely less than four inches across, as beautiful as the most exquisite Chrysanthemum, keeping in good condition longer than any other aster of this type. Blooms August to late frosts.

1009-Improved Crego Pink.

1010-Improved Crego Lavender.

1011-Improved Crego Crimson.

1012-Improved Crego Purple.

1013-Improved Crego Blue.

1014-Improved Crego Violet.

1015-Improved Crego White.

1016-Improved Crego Mixed.

Ang of the above. Pkt., 10c; 3 pkts., 25c; $1 / 4$ oz., 25c; oz., $70 c$.

QUEEN OF THE MARKET ASTER

One of the finest and earliest blooming va. rieties. Of branching habit, 18 inches high. 1017 -Mired Colors. Pkt., 10c; 1/4 0z., 20c; oz., 60c.

\section{FLOWER SEEDS}

OUR FLOWER SEEDS ARE FRESH EACH YEAR

There are no more satisfactory flowers than those grown from seed, especially the easily grown and Some flowers like dahlias, etc., wilt or fade soon after they are cut. Ordinary precaution is daily change old water and in a cold place. Do not hold flowers over the hot water, but dip the stems from CULTURE Cultural directions the dissolve an aspirin tablet in the vase. ully. While some seeds need special treatment, the following general rules will apply to all. Make the t of seeds to soil as fine, smooth and level as possible; do not plant when the ground is wet; cover each firmly over the seed. plant in rows so that the than four times the diameter of the seed; press

Plants are usually divided into three classes, annuals, biem weeds. wich normally live but a single season. Biennials are plants living two years. particularly those which

ABRONIA. See Sand Verbena.

\section{ACROCLINIUM - Everlasting}

ored double daisy-like flowers.

ADONIS - Pheasant's Eye Flos Adonis. Feathery foliage. Hardy annual.

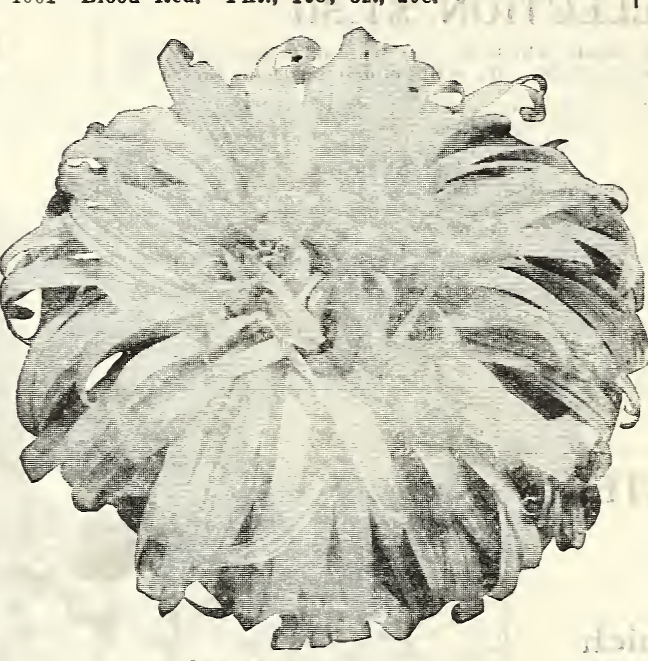

Improved Crego Aster.

\section{GIANT COMET ASTER}

Forms flowers of extraordinary size and beauty. A favorite European variety. 1018-Mired Colors. Pkt., 10c; 1/4 oz., 20c ; oz., $60 \mathrm{c}$.

\section{AMERICAN BRANCHING-SEMPLE'S ASTER}

The plant grows $11 / 2$ feet high. The blossoms, which are large and full petaled, are borne on long stems or branches.

1019-Mixed Colors. Pkt., 10c; 1/4 oz., 25c; oz., $75 \mathrm{c}$.

\section{OSTRICH FEATHER ASTER}

The flowers of this class resemble the Japanese Chrysanthemums, with long, curved, fringe-like petals, giving a feathery appearance; of immense size. $2 \frac{1}{2}$ feet.

1020-Finest Mixed. Pkt., 10c; 1/2 oz., 30c: oz., 50c.

\section{BALSAM - Lady .Slipper}

Sometimes called "Touch-Me-Not." The colors range from white to dark purple, sometimes spotted or striped. Tender annual. 1021-Dwarf Mixed-Double. Stalks 1 foot high. Pkt., 10c; oz., 50c.

1022-Camellia Flowered Mixed. Largest double variety. Plt., $10 \mathrm{c} ; 0 \mathrm{z} ., 75 \mathrm{c}$.

\section{AGERATUM - Floss Flower}

Very attractive dwarf border flower. Free flowring.

1002-Dwarf Blue. Pkt., 10c; 0z., 40c.

1003-Mixed Colors. Pkt., 10c; oz., 25c.

AGROSTEMMA. See Rose of Heaven.

\section{ALYSSUM}

These are without doubt one of the easiest flowers grown, for borders, baskets, pots, rockwork and for cutting. In borders, sow thickly, so as to form (asses.

04-Sweet Alyssum-Common. Pure white flowers of a delicate fragrance. Pkt., 10c; oz., 30c. 005-Little Gem or Carpet of Snow. One of the quickest growing border plants. Pkt., 10c; oz.,

\section{AMARANTHUS, Sweet Scented}

Plants are hardy annuals and are grown for their brilliant foliage. Especially suitable for ackgrounds, centers of beds, etc. Grows from 1006-Tricolor (Joseph's Coat). Leaves variegated : flowers crimson. Pkt., $10 \mathrm{c}$; oz., $70 \mathrm{c}$.

-Caudatus (Love-Lies-Bleeding). Long drooping crimson flower spikes with yellowish green
foliage. Pkt., 10c; 0z., 70c.

\section{ANCHUSA, Italica}

008-Dropmore Variety. Hardy perennial, growing about 5 feet; flowers are a clear, bright blue. kt., $10 \mathrm{c}$; oz., $\$ 2.50$.

\section{ANTIRRHINUM. See Snapdragon.}

AQUILEGIA. See Columbine.

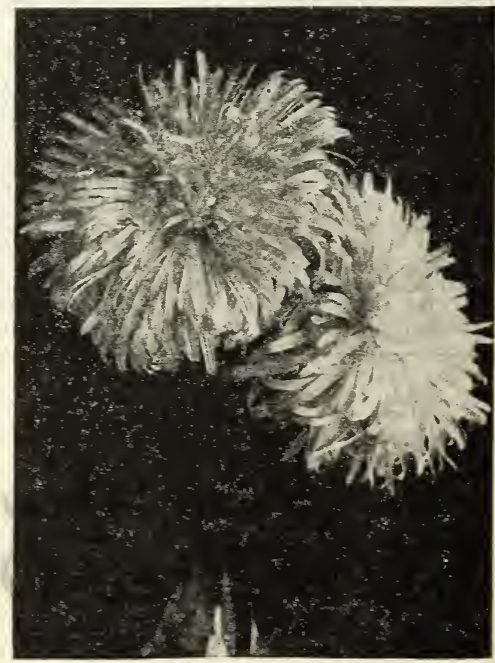

Comet Astera. 


\section{BABY'S BREATH - Gypsophila}

Small fragrant flowers, borne on long feathery stems. No flower adds more of light and grace to a bouquet than this, and when once grown will be found indispensable. 1023-Elegans Annual. The plants are covered with pure white flowers. Pkt., $10 \mathrm{c}$; 0z., 30c.

1024-Elegans Rosea. A beautiful soft pink. Pkt., 10c oz., 35c.

1025-Paniculata (Perennial). Single white, especially feathery and delicate. Pkt., 20c; 1/4 oz., 50c.

$10251 / 2$-Paniculata (Perennial). Double white Pkt.

$40 \mathrm{c}: 1 / 4$ oz. $\$ 1.00$

BACHELOR BUTTON. See Centaurea Cyanus.

\section{BALLOON VINE}

\section{(Love-in-a-Puff)}

Hardy annual climber growing 10 feet in height. Foliage light green. Bears small white flowers, followed by inflated seed pods resembling small balloons. Used mostly to cover fences, etc., because of its free and rapid growth. 1026-Pkt., 10c ; oz., 25c.

\section{BLACK-EYED SUSAN}

Hardy annual climber with flowers of buff, orange or white.

1027-Finest Mixed. Pkt., 10c; oz., 75c.

BRACHYCOME. See Daisy, Swan River.

\section{BROWALLIA}

Blooms profusely. Excellent plant for bedding or porch Blowers are bright blue and pure white. 1028-Pkt., 10c; oz., \$1.00.

\section{CALIFORNIA POPPY}

Cheerful blooms and finely cut foliage. Sow where plants are to remain. Hardy annual, grows one to one and one-half feet high.

1029-Thorburni. Coppery orange. Pkt., 10c; oz., 50c. 1030-Golden West. Bright yellow, orange base. Pkt.

$10 \mathrm{c}$; cz., $50 \mathrm{c}$.

1031-Californica. Rich yellow. Pkt., 10c; oz., 50c. 1032-Carmine King. Carmine-rose. Pkt., 10c; oz., 50c. 1033-Mixed Hybrids. Handsome colors. Pkt., 10c; oz., 50c.

\section{CALENDULA - Pot Marigold}

Large double flowers blooming all Summer, closing somewhat at night. Flowers grow $11 / 2$ to 2 feet high. In the past five years this has become very popular because it is so easy to grow, a constant bloomer, and a very desirable and decorative house flower.

1034-Double Orange King. Large, rich deep orange. Pkt., 10c; 0z., 25c.

1035-Double Lemon Queen. Large lemon or sulphur. Pkt., $10 \mathrm{c}$; oz., $25 \mathrm{c}$.

1036-Double Mixed. Mixture of several shades of orange, yellow, and primrose. Pkt., 10c; oz., 20c.

\section{CALLIOPSIS}

One of the easiest growing annuals. Very showy and excellent for cut flowers. Flowers grow 12 to 15 inches high.

1037-Tall Finest Mixed. Contains yellow, orange, brown, etc. Pkt., 10c; $1 / 2$ oz., $20 \mathrm{c}$.

\section{CANARY BIRD VINE}

Finely cut leaves and bears a profusion of beautiful golden yellow, fragrant flowers. Tall annual climber, growing $10 \mathrm{ft}$. Easily grown.

1038-Best quality. Pkt., 10c; oz., 40c.

\section{CANDYTUFT}

Requires little care; blooms all Summer. Sow in early Spring and in August. 12 inches high. Easy to grow. 1039-Empress. Large, white trusses of branching habit very free bloomer. Recommended for bedding and cut flowers. Pkt., 10c; oz., 50c.

1040-Mixed. Äll colors. Pkt., 10c; oz., $25 \mathrm{c}$.

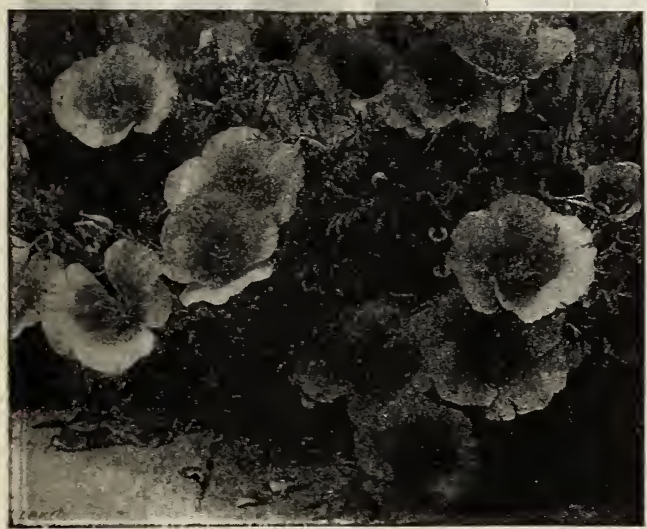

California Poppies.

CANNA

(Indian Shot)

Very showy plant with massive foliage and spikes of brilliant flowers. Seed should be soaked in warm water 24 hours before sowing. Height, three feet. 1041-Finest Mired. All colors. Plt., $10 \mathrm{c} ; 02 ., 60 \mathrm{c}$

\section{CANTERBURY BELLS}

(Campanula)

Bears a great profusion of attractive, bell-shaped flowers. Hardy perennial, grows from two to four feet.

1042-Single Mixed. Pkt., 10c; oz., 50c. 1043-Double Mixed. Pkt., 10c; oz. $\$ 1.00$.

\section{CASTOR OIL BEAN}

\section{(Ricinus)}

A flowering tropical appearing plant, growing to a height of 12 to 14 feet. Leaves grow to an enormous size. Used for ornamental purposes only.

1044-Zanzibarensis. Large variety.

Pkt., 10c; 0z., 20c.

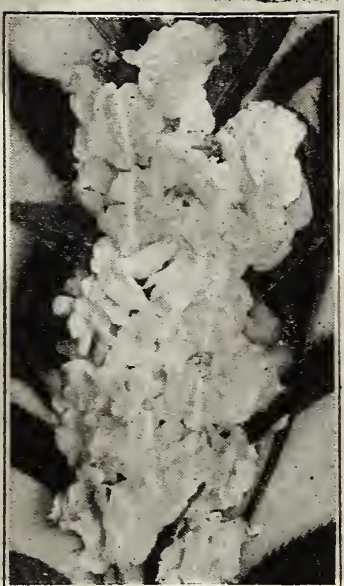

Balsam.

\section{CARDINAL CLIMBER}

An annugl climber and of rapid growth, attrining a height of 20 feet. Bears many small scarlet flowers.

1050. Pkt., 15c: 1/4 0z., 25 c.

\section{CATCHFLY}

Forms compact round bushes; produces dense umbels of red flowers; 12 inches.

1051-Pkt., 10c.

\section{CENTAUREA}

The popular Cornflower is also known as "Blue Bottle." "Ragged Sailor," "Kaiserblume," and "Bachelor Button." These are bright flowered plants of the hardiest nature and simplest culture, and yet the most attractive and graceful of all old-fashioned flowers.

\section{CENTAUREA CYANUS}

Bachelor Button, Corn Flower, Etc.

1052-Cyanus. Double, deep purple. Pkt., 10c; oz., 40c.

1053-Cyanus. Double, large blue. Pkt. $10 \mathrm{c} ; \mathrm{oz} ., 40 \mathrm{c}$

1054-Cyanus. Mixed, blue, purple, white, pink, etc. Pkt., 10c; oz., 25c.

CENTAUREA IMPERIALIS Sweet Sultan

1055-Imperialis. Yellow. Pkt., 10c; oz., 30c.

1056-Imperialis. Mixed. Pkt., 10c; oz., $30 c$ $50 \mathrm{c}$.

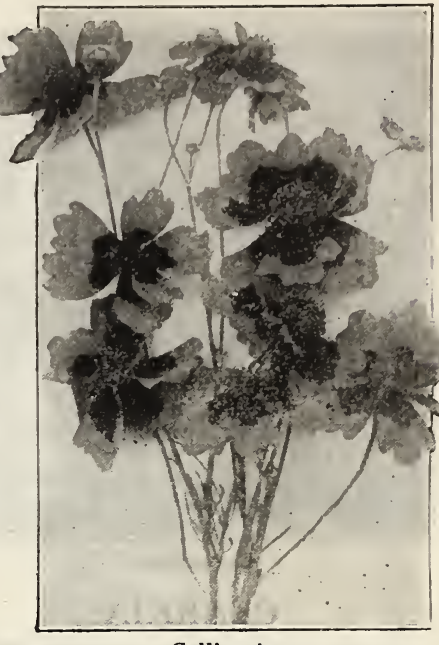

Calliopsis.

\section{CARNATION}

Are an extra vigorous race, especially adaptfor outdoor culture. They are very neat in it and are remarkable for their rich proof flowers. Can be sown in early Spring ors and transplant to the open.

\section{MARGUERITE}

One of the earliest to bloom. Flowers frarant, deeply fringed, suited for outdoor 045-Finest Mired. Pkt., 10c; 1/4 0z., 35c. CHABAUD'S

Everblooming earliest dwarf French variety. lowers in six months, large fine blooms. 6-Finest Double Mixed. Pkt., 15c; $1 / 402$. GIANT GRENADIN

This is an extra fine double variety, far to Marguerite.

8-Double Pure White. Pkt., 10c; $1 / 4$ oz. Double Mixed. Plt, 10c; 1/4 oz., 40c.

\section{CHINESE}

\section{WOOLFLOWER}

A unique free-flowering annual whose massive globular crimson-scarlet head resemble tufts of brilliantly colored wool. Its ease of culture and freedom of bloom throughout the Summer recommends it for general planting.

1057 -Finest quality. Pkt., 15c; $1 / 4$ oz. $50 \mathrm{c}$

\section{COCKSCOMB - Celosia}

A showy annual. Anyone who grows this flower is charmed by its beauty and fantasy of form. They thrive best in a rich, warm soil with plenty of sunshine. The heads will keep for weeks when cut and put into water.

058-Plumosa. Dwarf. The heads of this variety are very feathery and graceful, pyramidal in shape Plt. $10 \mathrm{c} ; 1 / \mathrm{O}$ oz $50 \mathrm{c}$

1059-Cristata. Tall. This variety has stiff, formal comb shaped heads; brilliant colors. Pkt., 10c; 1/2 oz., 50c. 1060-Plumosa and Cristata, Mixed. Pkt., 10c; 1/2 0z., 50c.

\section{CHRYSANTHEMUM}

Do not confuse these annuals with the winter-flowering sorts of the florists. They bloom profusely from early Summer until frost, and when grown in large beds or masses, their bright colors make a splendid show. All are fine for cut flowers. Height, 1 to $11 / 2$ feet. 061-Finest Single Mixed (Painted Daisy). Pkt., 10c; oz., 40c.

1062-Finest Double Mixed (Coronarium). Pkt., 10c; oz., 40c.

$10 \mathrm{c} ; 02 ., 75 \mathrm{c}$. 


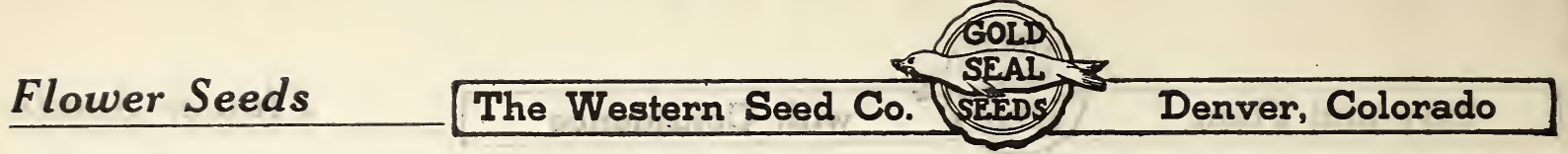

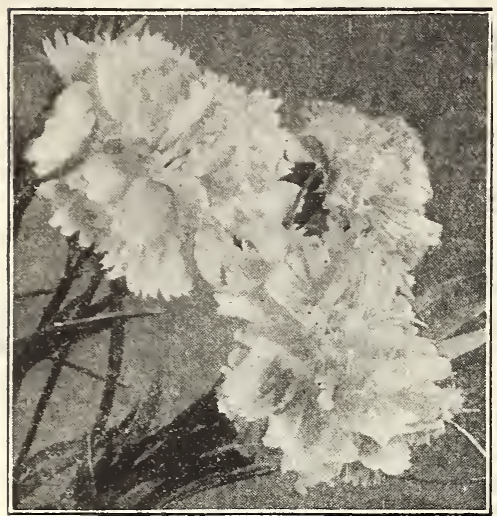

Carnations.

\section{CLARKIA}

A very pretty easy growing annual. Blooms early and freely, flowers in spikes of bright colors. Height, 2 feet. 1064-Double Mixed. Pkt., 10c; oz., 50c.

\section{COBAEA SCANDENS}

(Cup and Saucer Vine)

A perennial climber of rapid growth growing 20 to 30 feet in a season. Bears large bell-shaped purple flowers. Free from insects.

1065-Pkt., 10c; oz., 75c.

\section{COLUMBINE - Aquilegia}

Exceedingly showy, hardy plants, growing from 1 to $2 \frac{1}{2}$ feet high; do best in shady, moist places.

1066-Single Mixed. Pkt., 10c; oz., 75c. 1067-Double Mixed. Pkt., 10c; oz., \$1.00. 1068-Rocky Mountain. Very beautiful perennial a tive of Colorado. Color ranges ennial : native of Colorado. Color ranges white. Pkt., 10c.

We can supply roots if desired. See Shrubs.

\section{COLLINSIA}

A free-flowering and easily-grown annual, reaching a height of 1 to 2 feet. Clowers white, crimson,

1069-Best Mixed. Pkt., 10c; oz., 30c.

\section{COSMOS}

A strong, tall-growing annual, with bold A strong, tall-growing aintiness and airiness, fowers of exquisite daintiness and airiness, heightened in effect by their foliage-setting of feathery green. It is most effective when planted in broad masses or along background border against evergreens or fences. 1070-Early Flowering Mammoth Mixed Earliest of all. This new strain will produce flowers in July from seed sown in duce flowers in July from seed sown in tall. Pkt., 10c; oz., 35c。

1071-Extra Early Flowering, Pink. Pkt., 10c; oz., 35c.

EARLY FLOWERING DOUBLE CRESTED

We now have an extra early flowering strain of the double crested type which we recommend very highly for their grace and beauty. They come into flower fully as early as the extra early singles and bloom freely until frost. The flowers are large, ranging from 3 to 4 inches across, the double center standing up like a cushion. Finest mixed.

1072-Mixed. Pkt., 10c; 1/4 0z., 50c.

\section{CYPRESS VINE}

A tender annual climber with finely cut leaves and small star-shaped scarlet flowers. 1074-Mixed. Pkt., 10c; 0z., 35c.

\section{CUT FLOWERS}

This mixture contains all the main varieties of flowers suited for cut flowers and the ones that are easily grown.

1073-Best Mixture. Liberal Pkt., 10c ; oz.,

DAHLIA

Dahlias are of easy cultivation; growing freely in most any soil from seed in the Spring. Although perennial they will flower the first season if sown early.

er the first season if sown early. 1076-Single Mixed. Pkt., 10c; oz., \$1.25.

\section{DUSTY MILLER}

\section{(Centaurea)}

1082. An excellent plant for border, having graceful, arching silver-gray leaves. Plants grow from 1 to $11 / 2$ feet tall. Pkt. 10c; oz., 40c

DIANTHUS. See Pinks. DIGITALIS. See Foxglove. DOLICHOS. See Hyacinth Bean. DELPHINIUM. See Larkspur.

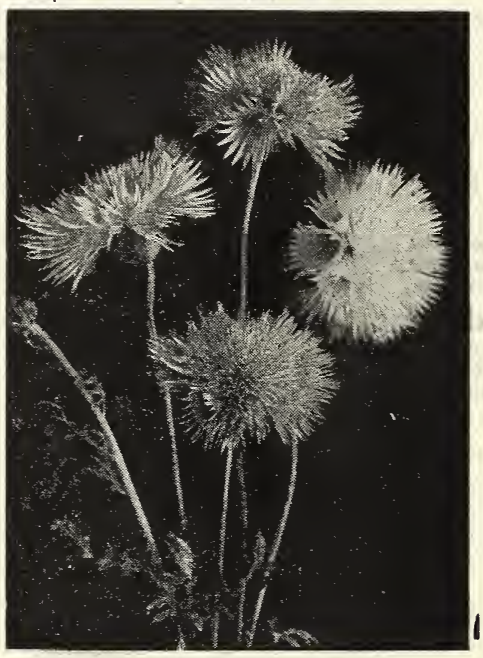

Centaurea-Sweet Sultan.

\section{DAISIES}

1077-Double English Daisy. Seed sown in early Spring will bloom the first Summer, and continue for years if given a slight protection during Winter. Should be sown in partial shade. H. P. 3 to 6 inches. Pkt., 10c. 1078-African Daisy (Dimorphotheca). Rare and very showy annuals, from South Africa; having daisy-like flowers of a glossy salmonorange shade with black central ring. A lovely color when flower is open in the sun. Height, one foot. Pkt., 10c; oz, \$1.25.

1079-Blue-Eyed African Daisy. Hardy annual easily grown from seed. The daisy-like flowers are silvery-white with a blue eye surrounded by a narrow golden band. The un der part of petals is lilac-blue. Pkt., 10c. 1080-Shasta Daisy. A hardy perennial; sometimes called the California Daisy ; a beautiful flower with large white petals and dark centers, measuring 3 to 4 inches across. Pkt $10 \mathrm{c} ;$ oz., $\$ 1.00$.

1081-Swan River Daisy (Brachycome) Free-flowering dwarf annuals covered during the greater part of Summer with a profusion of pretty blue and white flowers. Suitable for edgings. 9 inches. Pkt., 10c; oz., $\$ 1.00$.

ESCHSCHOLTZIA. See California Poppy. EVERLASTING FLOWERS

See Acroclinium, Globe Amaranth, Statice and Xeranthemum.

\section{EVENING PRIMROSE} (Oenothera)

1084. A free-flowering annual producing an abundance of large, single flowers which open in the evening. Pkt., 10c.
EVERLASTING SWEET PEAS

\section{(Lathyrus)}

1083. A hardy, perennial climber, growing 10 feet high. Flowers resemble Sweet Peas, but are borne on racemes with eight to ten flowers to the stem. Pkt., 15c.

\section{FEVERFEW - Matricaria}

1085. Pretty and neat. Small, double white flower, being hardy annual, growing 2 feet high. Pkt., 10c; oz., 50c.

FIRE PLANT. See Burning Bush.

FLOWERING SAGE. See Salvia.

FORGET-ME-NOT - Myosotis

These dainty little flowers love cool, moist soils, and like pansies, bloom most freely in Fall and early Spring. They make beautiful close borders or edgings.

1086-Mired. Pkt., 10c; 3 pkts., 25c.

\section{FOUR O'CLOCK}

\section{(Marvel of Peru)}

Plants are large and require plenty of space. Flowers sweet scented, funnel-shaped, being white red yellow or striped. Open about 4 o'clock in the afternoon. 2 feet.

o clock in the afternoon. 1088-Tall Mixed. Pkt., 10c; oz,, 20c.

\section{FOXGLOVE - Digitalis}

The tall, flower-like spikes of the Foxgloves, of ten 2 to 3 feet., are particularly handsome when grown among shrubbery or in masses. 1089-Mixed. Pkt., 10c; oz., 35c.

\section{GAILIARDIA}

10891/2-The Annual Gaillardias are very ef fective in beds, borders, etc.; and are also suitable for cutting. Pkt., 10c; 1/4 0z., 25c. 1090-Grandiflora (Perennial). A constant bloomer until late in the Fall. Flowers scarlet and orange. While this is a hardy Perennial it will bloom the first year from early planting. Height about $11 / 2$ feet. Pkt., 10c; 1/4 0z., 30c.

\section{GERANIUM}

The most popular bedding plants and for pot culture. The blooms are very brilliant and leaves are beautifully marked.

1091-Mixed. Double and single. Pkt., 20c.

\section{GLOBE AMARANTH}

Produces small, very showy, everlasting globeshaped flowers. When in full bloom should be cut and hung up to dry. Will hold their color Winter.

1092-Finest Mixed. Pkt., 10c; 1/2 oz., 20c.

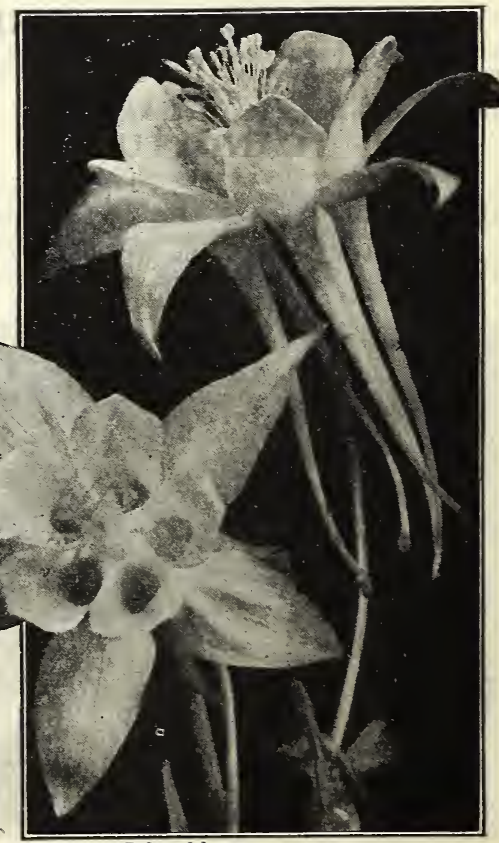

Columbine. 


\section{GODETIA - Satin Flower}

Rapid growing; large, Mallow-like flowers; very ornamental as pot plants or in mixed beds. Plants require plenty of room and thrive better in a 1093-Dwarf Varieties Mixed. Pkt., 10c; 1/2 oz., 20 c.

\section{GOURDS, ORNAMENTAL}

Climber. Quick growing vines; excellent for covering arbors, walls and waste places. Gourds grow in curious shapes and are used for house 1094-Finest Mixed Varieties. Pkt., 10c; oz., 20c.

\section{GYPSOPHILA. See Baby Breath.}

HELIANTHUS. See Sunflower.

\section{HELICHRYSUM - Giant Strawflowers}

The largest and showiest of the everlastings, are effective for winter bouquets mingled with Statice and other dried flowers. If wanted for drying, cut with as long stems as possible when the flowers are about onethird open. Strip off all the foliage, tie in small bunches and hang heads downward in some dark dry place until cured.

1095-Finest Mixed. Pkt., 10c; 1/4 oz., 20c.

\section{HELIOTROPE}

These well known greenhouse and bedding favorites are highly valued for their sweet scented flowers.

1096-Purple. Pkt., 10c; oz., \$1.50.

1097-Mized. Pkt., 10c; oz., \$1.50.

\section{HOLLYHOCKS}

These stately, old-fashioned perennials are most striking when seen in groups or long rows against evergreen hedges, shrubbery, etc., and, in their turn form a very fine background for plants of lower growth.

turn form a very fine background for plan 1099-Single Mixed. Pkt., 10c; oz., 65c.

\section{HYACINTH BEAN}

A fine climber with clusters of purple and white flowers.

1100 -Mixed colors. Pkt., 10c; oz., 25c.

\section{ICE PLANT}

1101. Flowers frosted or wax-like. Excel.

lent for hanging baskets or rockwork. Six inches. Pkt., 10c.

IMMORTELLES See Everlasting Flowers. IPOMOEA GRANDIFLORA See Moonflower.

IPOMOEA PURPUREA See Morning Glory IPOMOEA QUAMOCLIT See Cypress Vine

\section{JAPANESE HOP}

\section{(Humulus)}

1102. There is no hardier vine than this. Resists drought, and insects never bother it. The foliage is beautifully variegated. Pkt., 10c ; oz., $75 \mathrm{c}$.

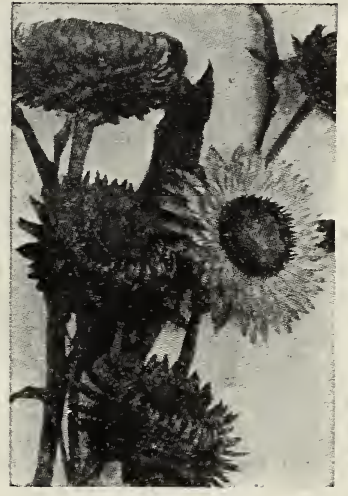

Helichrysum.

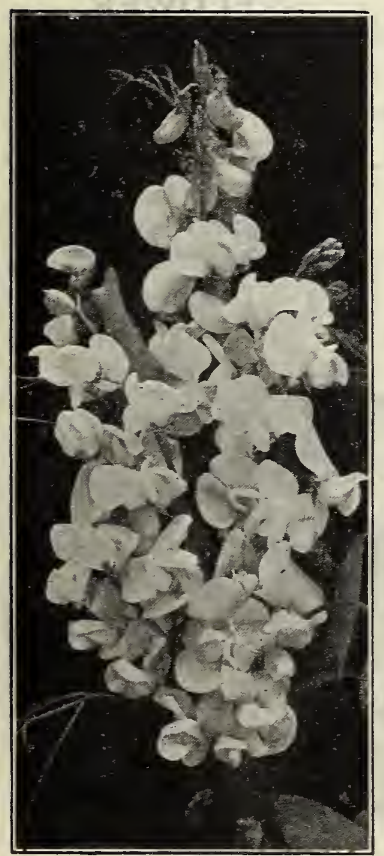

Everlasting Sweet Peas.

\section{JOB'S TEARS}

Curious ornamental grass with broad, corn-like leaves and lustrous slate colored seeds used for beads. Valuable for winter bouquets with everlastings.

1103. Pkt., 10c; oz., 15c. JOSEPH'S COAT See Amaranthus.

\section{KOCHIA}

\section{(Sammer Cypress)}

This splendid ornamental annual is sometimes called Burning Bush. The plants form a dense oval bush, 2 to 4 feet high. Light green foliage, chang. ing to carmine as Summer advances.

1104. Pkt., 10c; Oz, 25c.

\section{KUDZU VINE}

\section{(Jack-and-the-Beanstalk Vine)}

Hardy perennial climber. Grows 8 to 10 feet the first season from seed, each year getting larger. Forms a dense shade unequalled for porches, arbors, etc.

unequalled for porches, arb.

\section{LACE FLOWER}

Hardy annual. Grows about 2 feet in height, with lovely blue flowers. Make beautiful and lasting cut flowers. 1106. Pkt., 15c.

\section{LANTANA}

A rapid growing plant. The flowers borne in Verbena-like heads, embracing every shade of pink, purple, orange, and white. Height, about 2 feet.

1112. Pkt., 10c: oz., 50c.

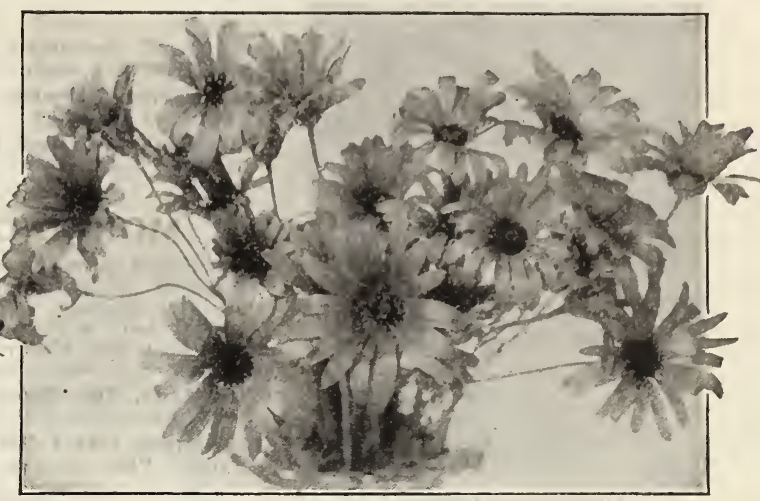

African Daisies.

\section{LARKSPUR}

ANNUAL

These free blooming annuals are very easily grown. Seeds planted in the open in Spring will soon produce beautifu flowers, borne on long spikes. Very effective in beds or masses. Grows two feet high.

1107-Double Mixed. Tall. Pkt., 10c; oz., 40c.

1108-Blue. Tall. Pkt., 10c; oz., 40c.

1109-White. Tall. Pkt., 10c; oz., 40c.

1110-Pink. Tall. Pkt., $10 \mathrm{c}$; oz., $40 \mathrm{c}$.

\section{DELPHINIUM}

\section{(PERENNIAL LARKSPUR)}

Hybrid Large Flowering. Single, semi-double and double in attractive shades of lavender, blue and purple. The plant are tall growing and are most desirable as a background for lower growing flowers or for planting in clumps in the open border

1111-Mixed. Pkt.. 10c; 1/2 oz., \$1.00.

\section{LOBELIA}

Charming little plants that bloom very quickly from seed, and continue gay with flowers all through the season.

1113-Royal Purple. Deep blue, with distinct white eye. Pkt. $10 \mathrm{c}$; oz., 75c.

1114-Tall Mixed. Pkt., 10c; oz., 65c.

\section{LOVE-LIES-BLEEDING. See Amaranthus.}

\section{MARIGOLD}

Old-fashioned annuals, rich and showy, blooming continually all Summer; excellent for bouquets and a beautiful garden plant. Tall African varieties are best for garden and cutting, while French and other sorts are especially adapted for edgings.

GIANT AFRICAN, DOUBLE

Three feet tall.

1115-Finest Mixed. Pkt., 10c; 1/4 oz., 45c. 1116 -Orange Prince. Pkt., $10 \mathrm{c}$; $1 / 4$ oz., $45 \mathrm{c}$. FRENCH, DWARF DOUBLE Eight inches tall. 1117 -Finest Mixed. Pkt., 10c; 1/4 oz., 45c. MARVEL OF PERU. See Four O'Clocks. MATRICARIA. See Feverfew.

\section{MAURANDIA}

Half hardy perennial, a beautiful rapid climber. Blooms profusely until late in the Autumn and will flower the first season from seed if sown early indoors and transplanted to a warm spot in the open.

1118. Pkt., 20c.

\section{MIGNONETTE}

A well-known favorite annual in all gardens. Cultivated for its fragrant flowers, which come quickly. Set in compact spikes. Sow in early Spring.

1119-Reseda Odorata Grandiflora. This is the sweet scented border variety. Pkt., $10 \mathrm{c}$; oz., 25 c.

1120-Improved Machet. Flowers are very large, of reddish green color, very fragrant. green color, very.

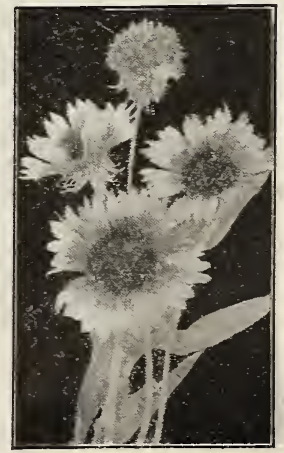

Gevlardias. 


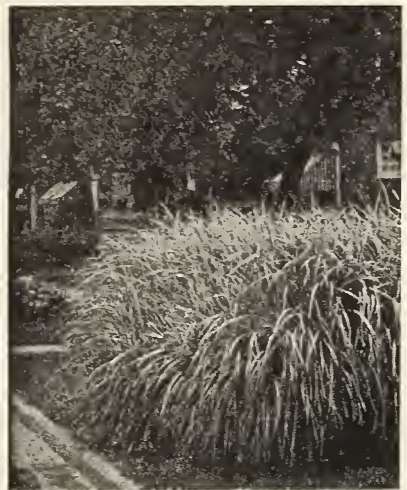

Ornamental Grasses.

1126-Blue Rochester. Heavenly blue. Pkt., 15c. 1127-Clark's Blue. Large light blue flowers. Pkt., $15 \mathrm{c}$.

1128-Imperial Japanese. Mixed. Bears hundreds of various colored flowers. Vines are very vigorous, growing to a height of 10 to 12 feet. Pkt., 10c; oz., 25c.

\section{MOURNING BRIDE}

\section{(Scabiosa)}

Well established garden favorites. They grow about 2 feet high and commence to bloom early in July, continuing until frost. The flowers are borne on long stems and last a long time when cut. Fine for beds or borders, growing two feet in height.

1129-Tall Double Mixed. Pkt., 10c; oz., 70c.

1130-Dwarf Double Mixed. Pkt., 10c; oz., 70c. MYOSOTIS. See Forget-Me-Not.

\section{NASTURTIUMS}

If you have space for them, you cannot have too many Nasturtums. Easy to grow in most any soil. Plant the seed anywhere. The tall kinds are especially suitable for covering fences, rockeries, trellises and the dwarf varieties especially adapted for borders. All Nasturtiums are very showy with their brilliant colored flowers and beautifully marked leaves. Prices, pkt., $5 \mathrm{c}$; oz., $15 \mathrm{c}$; $1 / 4 \mathrm{lb}$., $45 \mathrm{c}$; any six $5 \mathrm{c}$ peckets, $25 \mathrm{c}$, postpaid.

\section{TALL or CLIMBING}

\section{VARIETIES}

Besides their ordinary garden

\section{MIMULUS}

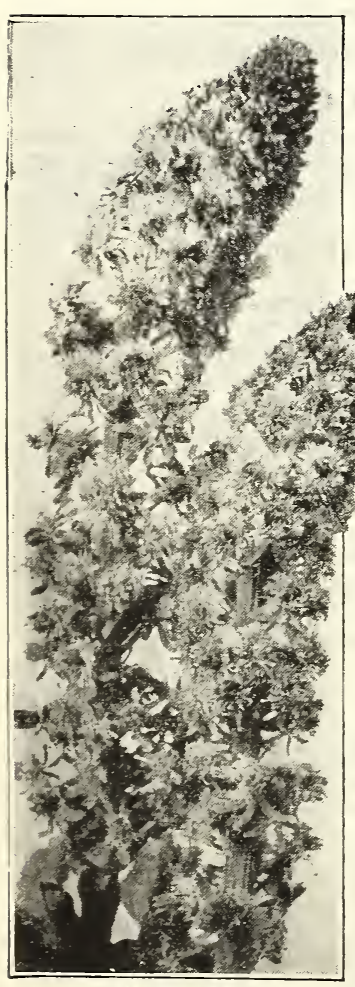

Mignonette. use for trailing over fences. trellis, stone walls, etc., these as screens.

1131-King Theodore. Dark red.

1132-Heinemann. Chocolate.

1133-Jupiter. Rich yellow large flowers.

1134--Pearl. Cream white.

1135-Von Moltke. Bluish rose. white and green. 5c; oz., $15 \mathrm{c} ; 1 / 4 \mathrm{lb}$., $45 \mathrm{c}$

1138-King Theodore. Dark red flower and dark leaf.

1139-Lady Bird. Rich yellow spotted scarlet.

1140-Golden King. Golden yellow, dark leaved.

1141--Pearl. Cream white.

1142- Empress of India. Dark scarlet flowers.

1143-Mixed. Contains all dwarf varieties. Any of the above, pkt., 5c; oz., $15 \mathrm{c} ; 1 / 4 \mathrm{lb} ., 45 \mathrm{c}$.

\section{NEMESIA}

Pretty annual; produces orchid-like flowers. 1144-Large Flowering. Pkt., 15c.

NICOTIANA - Flowering Tobacco feet. Sweet scented flowers.

1145 -Mixed. Pkt., 10c.

NIGELLA - Love-in-a-Mist

An eagy to grow annual. Flowers blue and white, foliage fine moss.

1146-Mixed. Pkt., 10c; oz., 50c. can be used for hanging baskets and for pot plants for winter flowering

1136-Variegated Leaved. Every leaf is variegated with yellow,

1137-Mixed. Contains all tall varieties. Any of the above, pkt.,

\section{DWARF OR TOM THUMB VARIETIES}

These have a neat, compact habit and attractive foliage, are not disturbed by insects, bloom in two months from sowing. Species of tobacco. Valuable as decorative plants. Height, 3

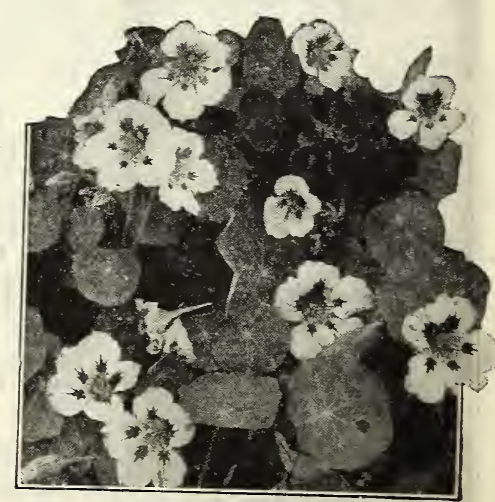

Nasturtiums. 


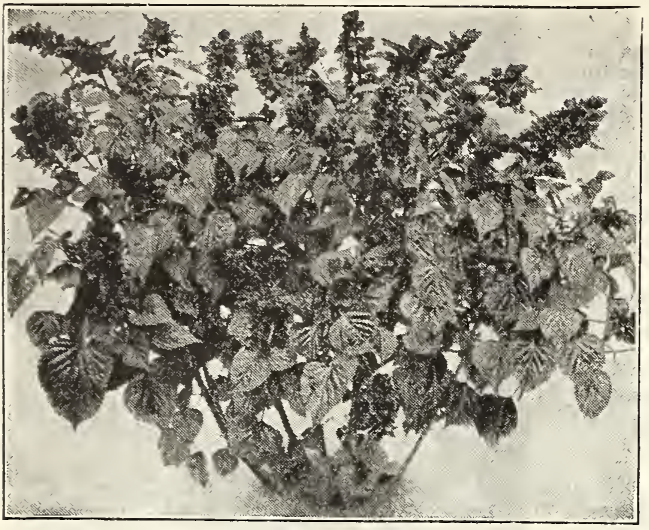

Salvia-Scarlet Sage.

\section{POPPY - Papaver}

ANNUAL VARIETIES

This is a quick, easily grown flower, rangIng in color from pure white to darkest crimson and violet. Plant in the open and thin to 8 inches apart. They will not transplant.

1167-Flanders Field. The famous poppy of Flanders Fields. Single annual of blood red color. Pkt., 10c; oz., 30c.

1168-Shirley. Beautifully crimped petals : wonderful shades of blue, lavender, salmon, etc. Pkt., 10c; oz., 30c.

1169-Carnation Flowered Double Mixed. Very double fringed; colors dazzling. Pkt., 10c; oz., 30c.

1170-Peony Flowered Double Mixed. Immense double, globular flowers. Pkt., 10c; oz., 30 c.

\section{PERENNIAL VARIETIES}

While these are perennials, they usually bloom the first year.

1171-Oriental. Enormous flowers; deep flashing scarlet; hardy perennial, growing 3 feet in height. Pkt., 10c; 1/2 oz., 50c.

ICELAND POPPY (Nudicaule)

This is the new Iceland Poppy, gracefully brilliant, excellent for cutting. Plant is low and compact. 1172-Finest Mixed. Pkt., 10c; 1/2 oz., 40c.

\section{ROSE OF HEAVEN - Agrostemma}

A hardy free blooming annual with flowers of bright rose. 'Two feet.

1177-Pkt., 10; oz., 30c

\section{SALVIA - Scarlet Sage}

A tender perennial blooming the first year from seed. Well known bedding plants with long, flaming flower spikes, displayed with striking effect against the deep preen foliage. $11 / 2$ to 3 feet.

1178 -Splendens. Height, 3 feet. Pkt., 10c; $1 / 4$ oz., 50c oz., \$1.50.

1179-Bonfire. Compact bush, growing 2 feet. Pkt., 10c $1 / 4$ oz., 50c; oz., $\$ 1.50$.

180-Coccines. Small scarlet flowers. Pkt., 10c; 1/2 oz. $20 \mathrm{c}$

\section{SALPIGLOSSIS - Velvet Flower}

Half hardy annual; grows 14 inches high. Flowers showy, large, funnel-shaped, mottled, veined and selfcolored. Requires rich soil.

1181-Mixed. Pkt., 10c; 1/2 oz., 50c.

\section{SCARLET FLAX - Linum}

1182-Grandifiora. A very attractive annual, growing 8 to 12 inches high. The rich, crimson flowers last but a day but they bloom continuously until frost. They like a warm sunny location. Pkt., 10c; oz., 40c.

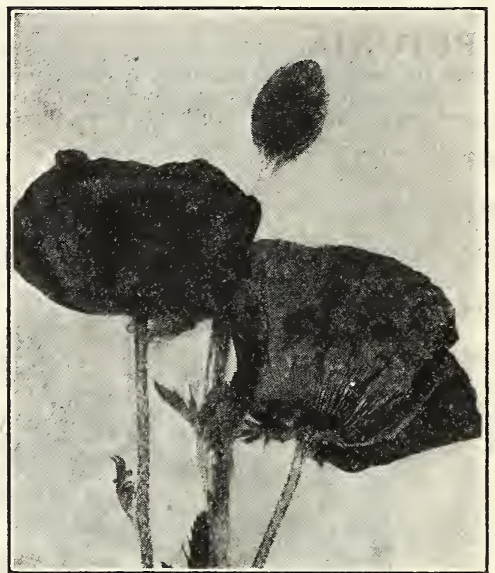

Oriental Poppies.

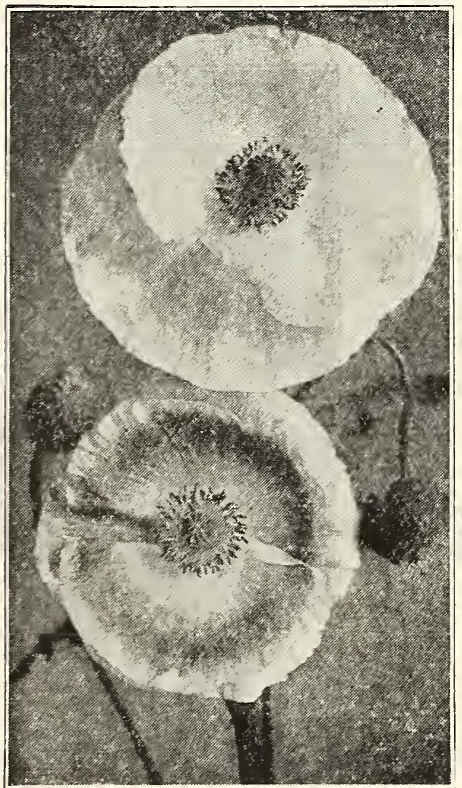

Shirley Poppies.

\section{SNAPDRAGON - Antirrhinum}

The Snapdragon is one of our finest perennials, flowering the first year from seed. Its bright-colored, curiously-formed flowers always excite interest. Height, $2 \mathrm{ft}$. 1187-Finest Tall Mixed. Pkt., 10c; oz., 75c.

1188-Finest Dwarf Mixed. Pkt., 10c; oz., 75c.

1189-White, Tall. Pkt., 10c; oz., 75c.

1190-Scarlet, Tall. Pkt., 10c; oz., 75c.

1191-Bright Rose, Tall. Pkt., 10c; oz., 75c.

1192-Golden Orange, Tall Pkt., 10c; oz., 75c.

1193-Yellow, Tall. Pkt., 10c; oz., 75c.

1194-Purple, Tall. Pkt., 10c; oz., 75c.

\section{SNOW-ON-THE-MOUNTAIN}

A very showy plant; makes a beautiful combination with other flowers.

1195. Pkt., 10c; oz., 25c.

\section{STOCKS}

Are used for bedding, borders, pot culture or bouquets. To secure early flowers, start seed in window-boxes or under glass in March or April, and transplant to the open ground in the middle of May. $11 / 2$ to 2 feet.

1197-Early Bismark (Double). Early blooming, 24 to 30 inches tall, of branching habit. Can be sown in the open. Pkt., 15c.

1198-Ten Weeks German. Finest double mixed, dwarf. Pkt., 10c; oz., $\$ 1.25$.

\section{STRA WFLOWER}

See Acroclinium, Globe Amaranth, Helichrysum, Statice, Xeranthemum Pkt. each of the above, 20c, postpaid.

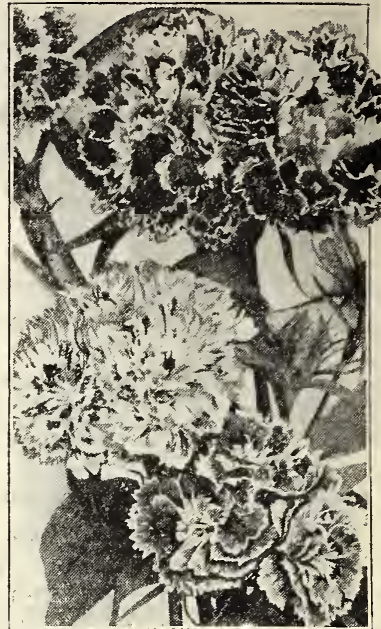

Chinese Pinks.

\section{SAND VERBENA} (Abronia)

Very pretty, trailing plants numerous clusters of sweet scented flowers. Rosy lilac, with white eye.

1183-Pkt., 10c. SCABIOSA

See Mourning Bride.

\section{SCARLET RUNNER BEAN}

Ornamental climber, with Excellent for porches or trellis.

\section{SENSITIVE PLANT}

The leaves instantly fold up when touched; elegant foliage. height $11 / 2$ feet.

1185. Pkt., 10c.

\section{SMILAX}

A perennial climber with deep glossy green leaves.

1186. Pkt., 10c.

\section{STATICE}

An easily grown everlasting an nual. They prefer a sunny situa tion. Very satisfactory for winter bouquets after being dried. 1196-Best Mixed. Pkt., 10c; 1/2 oz, 25 c.

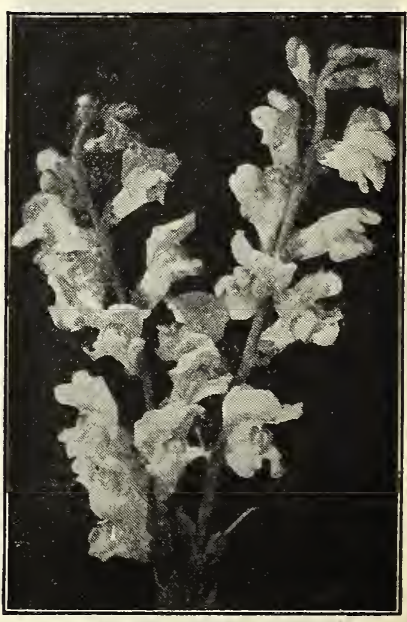

Snapdragon 


\section{Sweet Peas}

C.ULTURE. A deep rich moist soil is best suited for the growth of sweet peas. The ground should be worked or dug to a depth of six inches to one foot and mixed with bone meal or well rotted stable manure, leaving a hollow three inches deep for the seedbed. Sweet Peas should not be grown on the same soil longer than three successive years. If the location cannot be changed, the soil to a depth and width of a foot or more should be removed and replaced with soil from another part of the garden or grounds. Sow early, covering about one inch deep. Spring sowing should be made just as soon as the ground can be prepared. After the plants are two inches high, cultivate as they grow and a slight sprinkling of Flora Fertilizer worked into the soil will be a great benefit. When the plants are about 5 inches high some support should be furnished, such as brush, strings, wire netting, etc. One ounce of seed will plant 10 feet of drill.

\section{Spencer or Orchid Flowering Varieties}

TRUE SPENCER SWEET PEAS (Orchid Varieties). Many people believe that the Spencers are nothing more than large flowering varieties and selected from the common strains of sweet peas. But this is not true, for Spencer Sweet Peas are of a different and grander type; the color, curves, aroma and gigantic size attained through Spencer strains could never be found in the common grades. You will note from description that we have selected only the very best types of separate colors, those that we know will give satisfaction. Our Mixed Spencers contain all the standard varieties. including our selection of straight colors.

There are hundreds of varieties of sweet peas, and yet there is but a slight difference in many of the sorts and it is almost impossible for growers of sweet peas to decide and select the best varieties, so this year we are listing only the finest and best varieties of each class. For instance, there are many varieties of scarlet, but we list Hawlmark Scarlet, which has proven the best the world over. PRICES OF NAMED VARIETIES

Pkt., 10c; oz., 20c; $1 / 4$ lb., 65c; lb., $\$ 2.25$, pastpaid.

$$
\text { BLUE }
$$

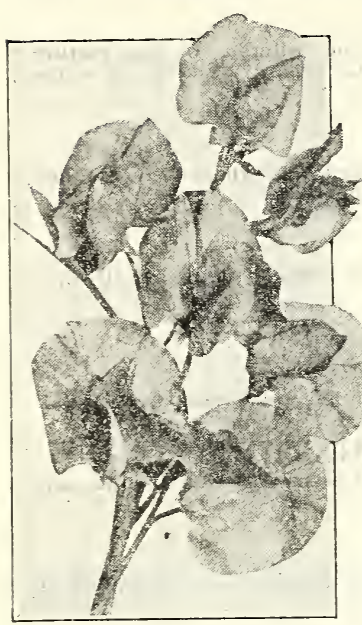

1501-Colne Valley. Light blue.

1502-Mrs. Tom Jones. Bright delphinium blue. 1503-Commander Godsall. Violet-blue.

1504-Doreen. Carmine-rose CERISE

1505-Royal Salute. Rich fiery cerise. 1506-Hawlmark Cerise. Rose-cerise. CREAM

1507-Dobbie's Cream. Deep primrose. 1508-Matchless. Cream.

$$
\text { PINK }
$$

1509.-Hercules, Mammoth rosy pink.

1509--Hercules, Mammoth rosy pink.

1511-Elfrida Pearson. Large blush pink. CREAM PINK

1512-Picture. Rose cream-pink.

$$
\text { CRIMSON }
$$

1513-Crimson King. Rich deep crimson. 1514-King Edward. Crimson self.

\section{LAVENDER}

1515-Austin Frederick, Imp. Giant lavender. 1516-Wembley. Delicate silver-lavender.

1517-R. F. Felton. Rosy lavender.

1518-Hawlmark Lavender. Pure pale lavender.

1519-Gladys. Lilac-lavender.

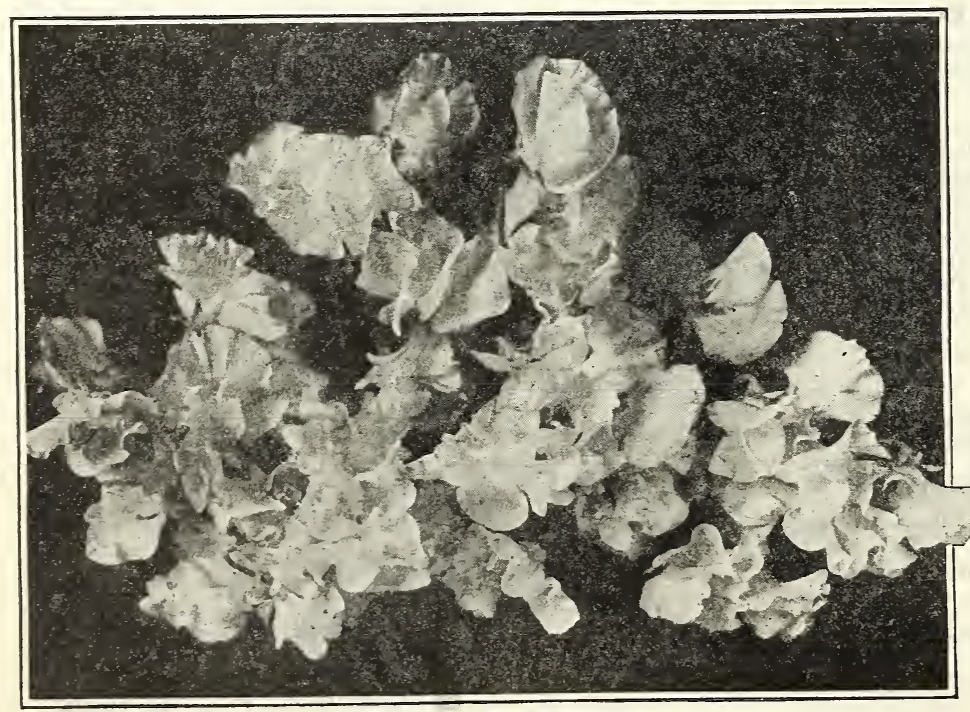

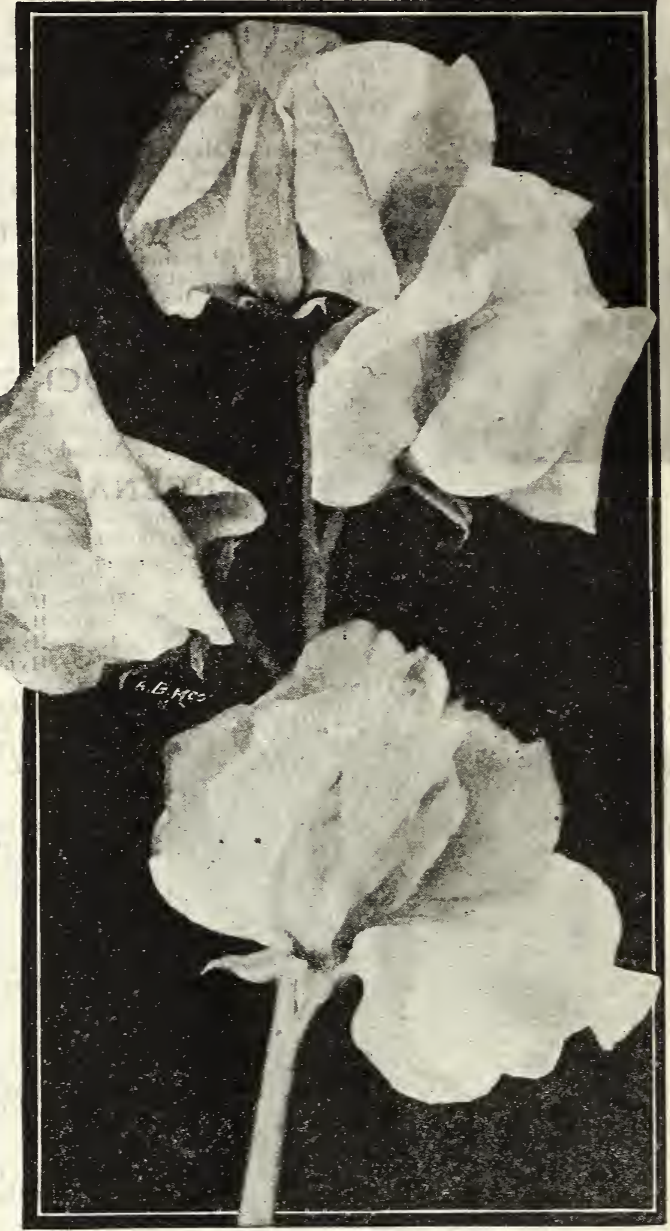

Enchantress Sweet Peas.

PURPLE

1520-Royal Purple. Large flower, color royal purple.

ROSE

1521-Rosabelle. Large light rose.

SALMON

1522-Barbara. Fine salmon.

1523-Stirling Stent. Salmon-orange.

SCARLET

1524-Hawlmark Scarlet. True scarlet.

WHITE

1525--Edna May, Imp. Large white waved. MAROON

1526-Sultan. Dark maroon.

1527-Warrior. Deep maroon.

\section{ORANGE}

1528-Tangerine Imp. Glowing orange.

1529-George Shawyer. Giant orange-salmon.

1530-The President. Orange-scarlet. PICOTEE

1531-Youth. Large white-pink picotee.

\section{Spencer Mixed}

The distinguished characteristics of the new Spencer Sweet Peas are the splendid form and gigantic flowirs, which are waved and fluted, which often measure two inches across. The stems sre very long and strong, and often bear four blossoms, which remain in bloom much longer than other sweet peas. This mixture includes all the Spencers we describe above, besides many other varieties to make a well balanced array of color and brauty. As sweet peas are one of our specialties, we aim to surpass all others in our sweet peas and we give our mixtures our special attention.

1535-Spencer Mixed. Pkt., 10c; oz., 15c; 1/4 lb., 50c ; 1 lb., $\$ 1.75$, postpaid. 


\section{SWEET PEAS-Continued.}

\section{California Giant Sweet Peas}

While the California Giant Sweet Peas are not as waved as the Spencers, yet they are very beautiful and produce an abundance of flowers of a large array of colors. They are a little easier to grow than the Spencer varieties. Culture is the same as the Spencer. All varieties of sweet peas do best in new soil.

\section{PRICES OF NAMED VARIETIES}

Pkt., 5c; 0z., 15c; $1 / 3$ lb., 40c; 1 lb., $\$ 1.25$, postpaid. 1636-Dorothy Eckford. One of the best of all white sorts. 1637- Hon. Mrs. Kenyon. The best yellow to date.
1638 - Prima Donna. Pure pink, large flower.

1638-Prima Donna. Pure pink, large
1639 -Prince of Wales. Rose crimson.

1640-Lady Grisel Hamilton. Best lavender, giant flowered. 1641-Black knight. Deep maroon.

1642-King Edward. Bright red. Large flowers.

1643-Captain of the Blues. Purplish mauve.

1644-Navy Blue. Brilliant blue.

1645-America. The brightest blood red, striped white

1646-Miss Wilmot. Orange pink, wings rose.

Any seven 5c packages of the above California Giants, $25 \mathrm{c}$.

1647-Gold Sesl Mixture. Every color of the rainbow. An almost unlimited variety of shades, tones and combinations of colors. The best and most desirable mixture possible to make, including the large flowering sorts and many magnificent Spencers. It is made up regardless of expense. This mixture was especially made to give satisfaction. Pkt., 5c; oz., 10c; 1/4 lb., 35c; 1 lb., $\$ 1.00$, postpaid.

1648- Striped Varieties, Mixed. A beautiful mixture made up exclusively of striped, mottled, and flaked varieties. Pkt., 5c; oz., 15c ; $1 / 4 \mathrm{lb}$., 50c; $1 \mathrm{lb}$., \$1.25, postpaid.

1649-Solid Color Mixture. This mixture consists of the most beautiful varieties of solid colors, for many of our patrons do not care for the striped or variegated varieties, but prefer a mixture containing such colors as red scarlet, violet, blue, purple, white, pink, lavender, macolors as red, scarlet, violet, blue, purple, white, pink, lavende
roon, etc. Pkt., 5c; 0z., 15 c; $1 / 4$ lb., 50c; 1 lb., $\$ 1.50$, postpaid.

\begin{tabular}{|c|}
\hline $\begin{array}{c}\text { Spencer Sweet Pea Collections } \\
\text { "GREAT SIXTEEN" COLLECTION, POSTPAID, } \$ 1.00 \\
\text { Regular Price, } \$ 1.60 \\
\text { One pkt. each of the } 16 \text { different varieties named below }\end{array}$ \\
\hline \begin{tabular}{lll|} 
Colne Valley & Austin Frederick & $\begin{array}{l}\text { Hawlmark Scarlet } \\
\text { Doreen }\end{array}$ \\
Royal Salute & Hercules & Edna May \\
Dobbie's Cream & Royal Purple & Sultan \\
Picture & Rosabelle & Tangerine \\
Crimson King & Barbara & Youth \\
"GREAT FOUR" COLLECTION, POSTPAID, 30 CENTS
\end{tabular} \\
\hline $\begin{array}{ll}\text { Rosabelle } & \text { Asta Ohn } \\
\text { King Edward Spencer } & \text { Wembley }\end{array}$ \\
\hline \begin{tabular}{lll}
\multicolumn{1}{c}{ “GREAT SEVEN" } & COLLECTION, POSTPAID, 50 CENTS \\
Eegular Price, 70c & \\
Edna May & Royal Purple & Hawlmark Pink \\
R. F. Felton & King Edward & Dobbie's Cream \\
Stirling Stent &
\end{tabular} \\
\hline
\end{tabular}

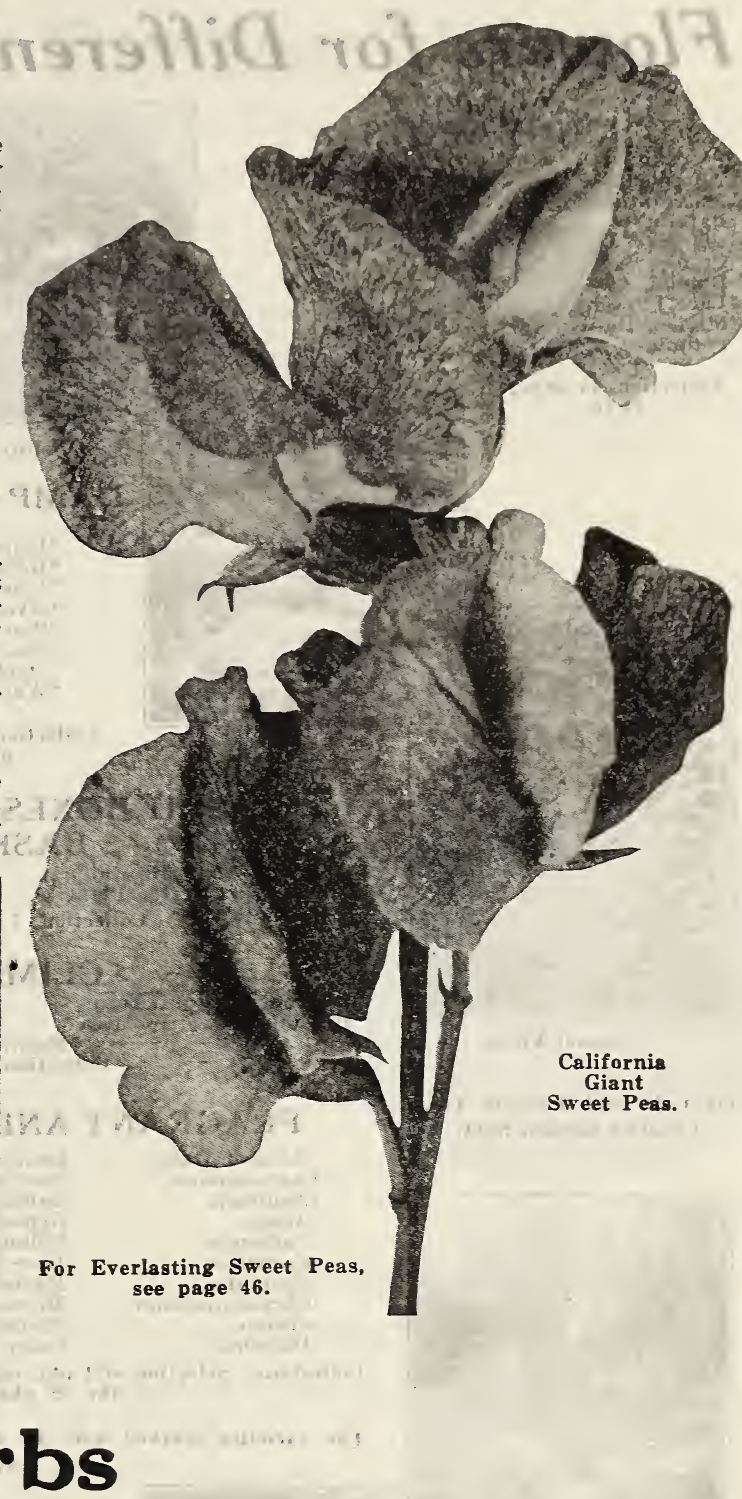

ANISE. An annual, cultivated principally for the seeds, which have a fragrant smell and pleasant taste. Used for medicinal purhave a fragrant smel and pleasant taste. poses; leaves used for
$1 / 4 \mathrm{lb} ., 35 \mathrm{c}$; lb., $\$ 1.25$.

BASIL, SWEET. A hardy annual from the East Indies. Seeds and stems have a flavor similar to cloves and are used for flavoring soups. Pkt., 5c; oz., 15c; $1 / 4$ lb., $45 c$; lb., $\$ 1.50$.

BORAGE. Leaves used for flavoring, and flowers furnish bee pasturage; most easily grown in any waste place. Pkt., $5 \mathrm{c}$; oz., 15c; $1 / 1 /$ lb., 40c; 1 b., $\$ 1.25$.

CARAWAY. Cultivated for its seed, which is used in confectionery, cakes, etc. Leaves are sometimes used in soups. If sown in ery, cakes, etc. Leaves are sometimes used in soups. If sown in in the Spring will not generally seed until the next year. Pkt.. 5c: in the Spring will not genera
oz., 10c; $1 / 4$ lb., 25c; lb., 75c.

CATNIP. Leaves and young shoots used for flavoring. Pkt., 5c; oz., 35c.

CORIANDER. A hardy annual, cultivated for its seed, which has an agreeable taste and is used in confectionery and to disguise the taste of medicine. Pkt., 5c; oz., 10c; 1/4 lb., 20c; 1b., 60c.

DILL. An annual, cultivated for its seed, which is aromatic and has a warm pungent taste. Its seeds are used for seasoning. It possesses medicinsl values but its largest use is for seasoning in dill pickles. Pkt., 5c; oz., 10c; 1/4 lb., 25c; lb., 75c.

LAVENDER. An aromatic and useful medicinal herb. Pkt., 10c: oz., 30c; $1 / 4 \mathrm{lb}$., $85 \mathrm{c}$; lb., $\$ 3.00$.

SWEET FENNEL. A hardy perennial; leaves used in soups, fish sauces, garnishes, and salads. Pkt., 5c; oz., 15c; $1 / 4$ lb.. 45 : lb., $\$ 1.50$.

HOREHOUND. A perennial herb with a strong aromatic smell bitter pungent taste. Used as a tonic and enters into the composition of cough syrups. Does fine in poor soils. Pkt., 5c; oz., 35c: $1 / 4 \mathrm{lb}$., $\$ 1.10$.

ROSEMARY. The leaves are aromatic and used for medicinal purposes only. Pit., 10c; 0z., 45c; $1 / 1 \mathrm{lb}$., $\$ 1.35$.

SAVORY, SUMMER. A hardy annual; when dried, stems, leaves and flowers are extensively used for soups and dressings: Pkt., 5c oz., $15 \mathrm{c} ; 1 / 4 \mathrm{lb}$., $40 \mathrm{c}$; lb., $\$ 1.25$.

SAFFRON (Carthamus tinctorius). Used in medicine and also in dye. Pkt., 10c; $1 / 2$ oz., 25c.

THYME. A perennial used both medicinally and as a culinary plant. The young leaves and tops are used for soups, dressings, an sauces. A tea made of the leaves sometimes relieves nervous headaches. Pkt., 10c; 0z., 30c; 1/4 lb., 85c; lb., $\$ 3.00$.

SWEET MARJORAM. A perennial plant but not hardy enouirh to stand the northern winters. Young tender tops are used for fiavoring and may be cut and dried for winter use. Pkt., 10c; oz. $30 \mathrm{c}$; $1 / 4 \mathrm{lb}$., $85 \mathrm{c}$; lb., $\$ 3.00$.

SAGE. A hardy perennial, possessing some medicinal properties, cultivated principally as a condiment, being used more extensively than any other herb for flavoring and in dressing. Pkt., 10c: oz. $30 \mathrm{c}$ : $1 / 4 \mathrm{lb}$, $\$ 1.00 ; \mathrm{lb}$., $\$ 3.50$.

SORREL. Broad leaved perennial. used in soups and salads and sometimes cooked like spinach. Pkt., 5c; oz., 10c; 1/4 lb., 35c: lb., $\$ 1.00$.

WORMWOOD. Leaves used as a tonic. A dry poor soil is best $f_{0}$ th is plant. Pkt., $5 \mathrm{c}$; oz., $15 \mathrm{c}$; $1 / 4 \mathrm{lb}$., $45 \mathrm{c}$; lb., $\$ 1.50$. 


\section{Flowers for Different Purposes $\begin{gathered}\text { All Are Easily } \\ \text { Grown trom Seed }\end{gathered}$}

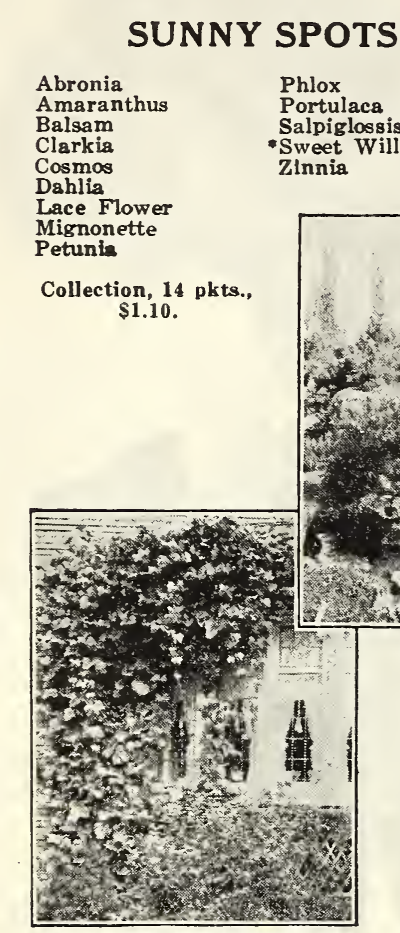

Annual Vines.

Try Gold Seal Seeds in Your Favorite Garden Spot.

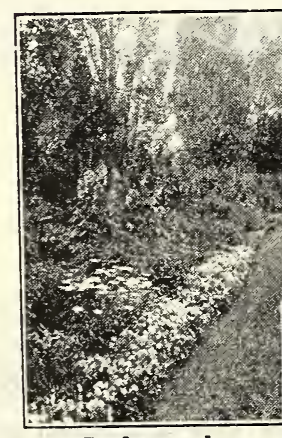 \\ Backgrounds. \\ ROCK \\ GARDENS \\ Abronia \\ Alyssum \\ Candytuft \\ Ice Plant \\ Verbena \\ Collection, 6 pkts., $30 \mathrm{c}$.}

MASSED COLORS

$\begin{array}{ll}\text { Ageratum } & \text { Phlox } \\ \text { Candytuft } & \text { Poppy } \\ \text { Celosia } & \text { Portulaca } \\ \text { Helichrysum } & \text { Salvia } \\ \text { Nasturtium } & \text { *Sweet William }\end{array}$

Collection, 10 pkts., 75 c.

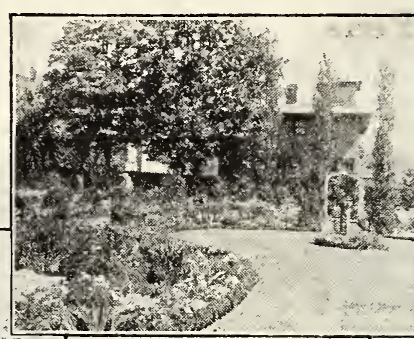

$$
\begin{aligned}
& \text { Sunny Spots. } \\
& \text { DAMP SPOTS } \\
& \text { * Delphinium } \\
& \text { * Heliotrope } \\
& \text { * Lobelia } \\
& \text { * Pansosotis } \\
& \text { * Snapdragon } \\
& \text { - Stocks } \\
& \text { * Wallflower }
\end{aligned}
$$

Collection, 8 pkts..
NATURALIZING

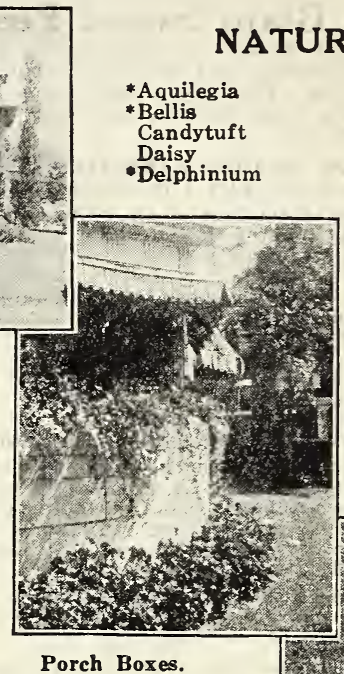

Porch Boxes.

* Digitalis

* Hollyhock

* Lobelia.

Metunis

Petunis

Poppy

* Pyrethrum

*Sweet William $\$ 1.10$.

Damp Spots.

$60 \mathrm{c}$

Collection, 14 pkto.

PORCH BOXES and HANGING BASKETS

$\begin{array}{ccc}\text { Abronia } & \text { Browallia } & \text { Lobelia } \\ \text { Alyssum } & \begin{array}{c}\text { Ice Plant } \\ \text { Collection, } 7 \text { pkts., 50c. }\end{array} & \text { Verbena }\end{array}$

\section{CLIMBERS}

$\begin{array}{lll}\begin{array}{l}\text { Balloon Vine } \\ \text { Humulus }\end{array} & \begin{array}{l}\text { Cobaes } \\ \text { Ipomoes }\end{array} & \begin{array}{c}\text { Cypress Vine } \\ \text { Kudzu Vine }\end{array} \\ \text { * Lolichos }\end{array}$ Morning Glory
Collection, 9 pkts., 70c.

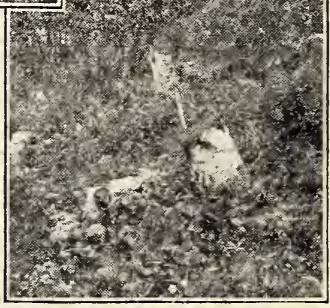

Naturalizing.
FRAGRANT AND CUT FLOWERS

African Daisy

Agrostermm

* Aquilegia

Asters

Calliopsis

Carnation

Chrysanthemum

Cosmos

Cosmos

Eschscholtzia
Everlastings
Gaillardia
Gypsophila
Heliotrope
Lace Flower
Marigold
Mignonette
Nasturtium
Pansy

Petunia

Poppy

- Pyrethrum

Salpiglossis

Scabiosa

Sweet Pea

*Sweet Rocket

Zinnia

Collection: Selection of 1 pkt. each of 12 of above varieties for $90 \mathrm{c}$, or the 29 pkts. listed, $\$ 2.00$.

The varieties marked with an asterisk (*) are best treated as perennials.

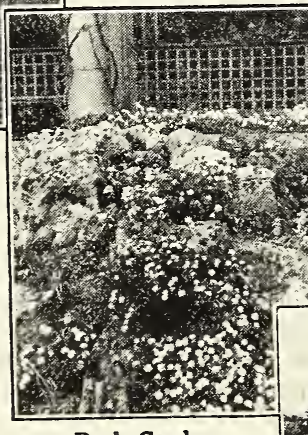

Rock Garden.

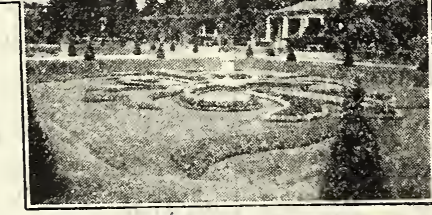

Massed Colors.

*Delphinium

* Digitalis

Hollyhock

Collection, 4 pkts., 25c.

No Disappointments in Gold Seal Seeds.

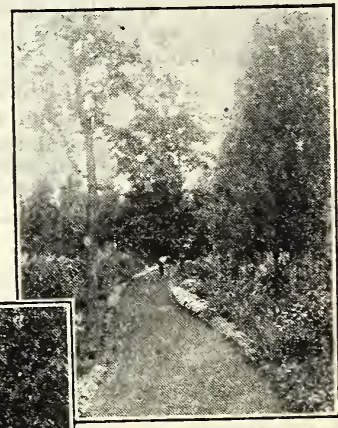

Edging.

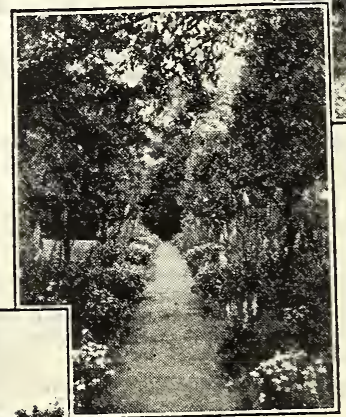

Shaded Corners.
SHADED CORNERS

*Aquilegia

* Bellis.

Clarkia

* Mimulus

* Myosoti

*Pansy Collection, 6 pkts., 50 c.

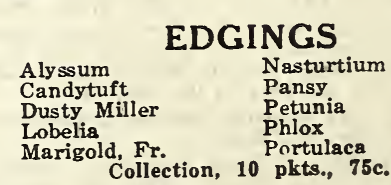




\section{Nursery Stock for the West}

\section{Fruit and Shade Trees, Berries, Small Fruits, Roses, Plants and Roots Our Stock is State Inspected and is Free From Disease}

\section{Suggestions to Planters}

We have a good supply of carefully grown nursery stock, fruit and shade trees, roses, shrubbery, plants, etc., and we believe our prices are sufficiently low to be attractive. However, it is the quality and not the prices that we wish to call your attention to. Our stock is all number one and includes all the varieties which are popular and that do well in our western climate. We, therefore, feel confident that your requirements will be taken care of to your entire dent that your requirements will be able to buy at a lower price, but not of satisfaction. the same quality. Remember, a low grade tree does not have the
vitality to show a prolific growth and is always a rather poor tree vitality to show a prolific growth and is always a rather poo
throughout its life. Therefore, it is a very poor investment.

Success depends in a large measure on the treatment given to stock after it is received by the planter. Thousands of well grown, healthy specimens delivered in first-class condition, are annually lost through neglect and bad treatment. The natural place for roots of trees is in the ground; preparation for their arrival should be made, everything should be ready and the trees or shrubs planted as soon as possible. As soon as you receive your nursery stock, remove the packing, sprinkle the roots and heel in the bundle in moist ground, packing, sprinkle the roots and heel in the bundle in moist ground,
covering entirely about 4 to 6 inches. In planting take up only a few trees or shrubs at a time and never allow them to lay exposed to the air and sun at any time. Remove all broken roots with sharp knife and cut back the tops about one-half of last season's growth. Dig the hole large enough to admit all the roots in the natural position, keeping the surface soil and the sub-soil separate In filling in sift the best soil in around the roots. When most of In filling in sift the best soil in around the roots. When most of the soil is filled in, pour in the water to wash the soil around the roots, then pile up the remainder and tread down gently with the font. After this the tree or shrub should only be watered when the soil gets dry about two or three inches below the surface. A mulch around the base of the tree, two or three inches thick, is very beneficial.

\section{Prices}

Our prices on nursery stock include packing and drayage to freight or express depot, but not prepay charges. The purchaser is to pay the freight or express charges unless arrangement has been made with us before goods are shipped. Mail us your list and we will make you a special delivered price.

Upon special request we will ship fruit trees by mail but they must be cut down to comply with postoffice rules and buyer must assume risk of safe delivery.

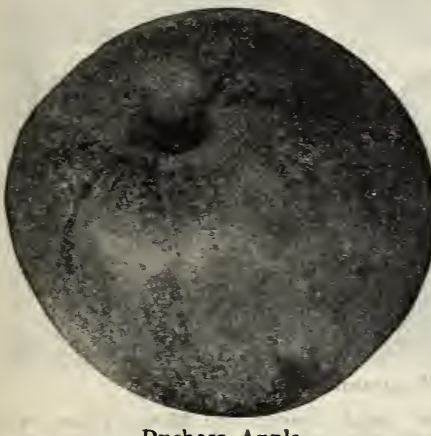

Duchess Apple.

\section{APPLES}

We are listing only the varieties that have proven a success in the West and we know that with the proper care and attention that is due to any tree, a crop of fruit will result from any one of the many we have listed.

Prices, on all varieties of apples and crab apples : First grade $11-16^{\prime \prime}$ and up in diameter, 5- $\bar{t}^{\prime}$ high, each, $75 \mathrm{c}$; in lots of five to ten, assorted rarieties if desired, each. 70c. Larger amounts, assorted varieties if desired, each, $60 \mathrm{c}$.

\section{Summer Apples}

EARLY . HARVEST. Medium to large; pale yellow, white fleshed, tender and sub-acid; ripens early during the Summer; very productive.

YELLOW TRANSPARENT. Early to ripen; pale yellow when full ripe, of medium size, tender and good: free-growing and fruitful. Its early fruit is always welcomed.

\section{Autumn Apples}

MAIDEN BLUSH. Medium size round, flushed with red on creamy yellow; very handsome; tender flesh.

WEALTHY. The most popular early variety known; heavy producer, of medium size, red apples. One of the finest early eating or cooking varieties; everyone should plant Wealthy apples.

DUCHESS OF OLDENBURG. A large sized apple of yellow color, streaked red. Very juicy and a heavy yielder. Ripens in September. One of the best for Colorado.

\section{Winter Apples}

DELICIOUS. A most wonderful apple of unusually fine flavor originated in our western country. The fruit is large, of a brilliant, dark red color; juicy, crisp, and melting. Heavy cropper.

GRIMES' GOLDEN. Medium sized, beautiful golden color; does well in the West; splendid keeper.

JONATHAN. The old standby-heavy producer, brilliant red, sweet and jaicy; excellent keeper.

MAMMOTH BLACK TWIG. A large, dark red apple; fine eating and cooking; good keeper.

NORTHWESTERN GREENING. Very late to ripen, but keeps solid a long time, rich golden color: very productive.

ROME BEAUTY. Extra large and handsome, yellow, with crimson cheek; juicy and bears heavy.

STAYMAN'S WINESAP. Larger and more prolific than the old Winesap. Rich dark red; frm, fine grained and juicy. Adapted to a wide range of soils and climates.

NORTHERN SPY. Vigorous growth; large, striped red, tender, juicy, mild, sub-acid : very good. A fine dessert fruit. Keeps through Winter and late into the Spring.

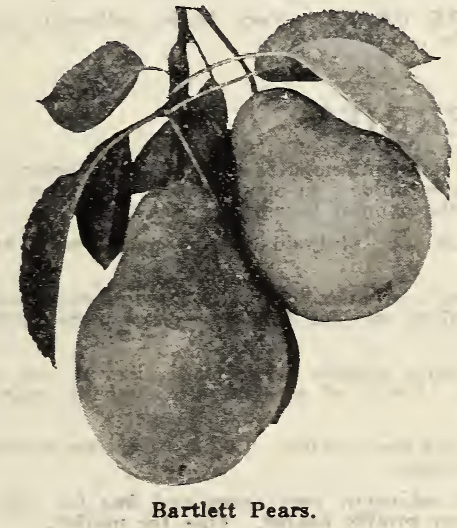

Prices on all varieties of pears: First grade, $11-16^{\prime \prime}$ and up in diameter, 5-7, high; each, $\$ 1.10$; in lots five to ten, each, $\$ 1.00$.

BARTLETT. Large, buttery, juicy, high flavored; bears early and abundantly.

FLEMISH BEAUTY. Large, red cheeked and beautiful, of excellent quality, hardy, and
productive. Very popular in the West. Ripens productive. Very popular

KIEFFER. Its large size, handsome appearance and remarkable keeping qualities make it very desirable. Ripens October and November

\section{DWARF}

First grade, 5/8" and up, $\$ 1.00$ each.

BARTLETT. Same as the standard variety DUCHESS. Flesh white with rich buttery favor, very large. 


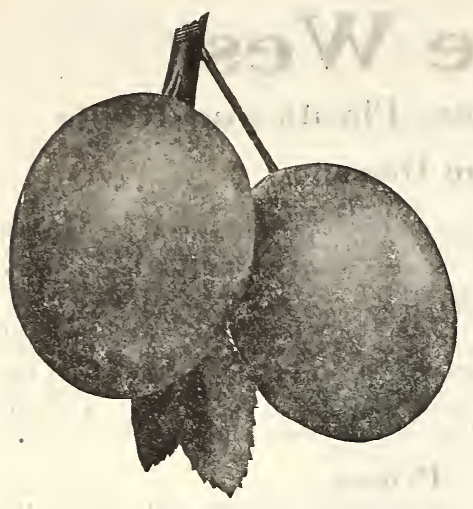

Lombard Plums.

\section{PLUMS}

The plum may not be so important as some other fruits, but it is gaining more in popularity every year and has been planted extensively the last few years. As it is a native fruit it grows easily and is a great bearer and should have a place in every orchard and fruit garden. Our list is confined to the American varieties, with the exception of one, because they are better adapted to our locality.

\section{PRICES ON ALL VARIETIES OF PLUMS}

First grade, 11-16" and up in diameter, 5-7' high; each, $\$ 1.10$; in lots of five to ten, assorted varieties if desired, each, $\$ 1.00$; larger a mounts, assorted varieties if desired, each, $90 \mathrm{c}$.

LOMBARD. Medium to large; dark red, flesh yellow; of pleasant flavor, very prolific and does well in this locality.

MOORE'S ARCTIC. Small, purplish black, juicy, sweet, immense bearer. One of the hardiest in bud and bloom.

OMAHA. Medium size, dark red, of good quality; very hardy and heavy bearer under all conditions and ripens early. One of the most popular plums.

OPATA. A cross between Dakota Sand Cherry and the Japanese Gold Plum. A good grower, early a nd very productive; fruit dark purplish red color, with green flesh of a very pleasant flavor.

HANSKA. This is a cross between the Native Plum and the fragrant apricot of China. It is hardy and a strong grower; fruit of bright red color, with heavy blue bloom. Flesh is firm, yellow, of good quality and very fragrant.

WANETA. This wonderful large plum of Professor Hansen's production is the most delicious of all plums. It is hardy and very prolific; fruit of largest size, deep red color and a delicious flavor.

GREEN GAGE. Large, round ovate; green, marked with

\section{CHERRIES}

More satisfaction can be had from cherry trees than any other trees. They are a beautiful sight from blossom to fruit and very seldom fail to produce; every farm, garden or ranch should have cherries. They do not demand much attention.

PRICES ON ALL VARIETIES OF CHERRIES

First grade, 11-16" and up in diameter, 5-7' high, each, \$1.25; in lots of five or ten, assorted varieties if desired, each, \$1.15. Larger a moants, assorted varieties if desired, each, $\$ 1.00$.

EARLY RICHMOND (Pie Cherry). A reliable old standard, with dark red fruit of medium size, very productive.

ENGLISH MORELLO. Large; dark red, nearly black; tender, juicy and rich. Tree is dwarf-midseason.

LARGE MONTMORENCY. Larger and finer than the Richmond and one of the finest flavored cherries in this class; valuable for canning and pre serving.

OSTHEIMER. A perfectly hardy, late blooming, immensely productive variety. Large, heart-shaped, nearly black when ripe; juicy and rich.

WRAGG. Very hardy, vigorous and productive, medium dark purple, fine

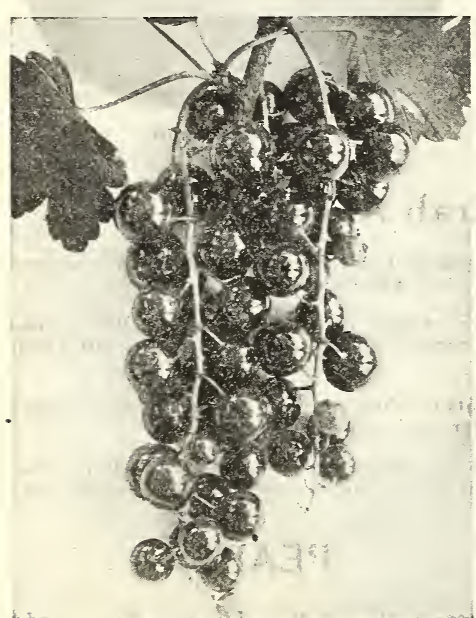
quality. Usually sure cropper. will bring greater returns in money. post, add 2c per plant. the table. red in the sun; hangs long on the tree. Ripens in September. WILD GOOSE. Well known, large deep red when ripe, of good quality. One of the best native plums.

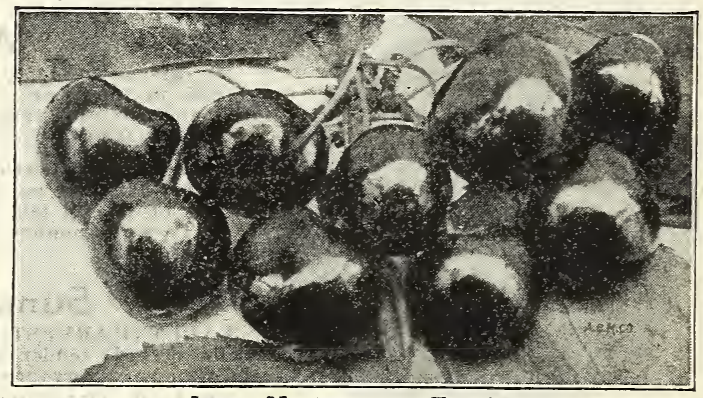

Large Montmorency Cherries.

COMPASS CHERRY. This fruit is a cross between the Sand Cherry and Miner Plum and looks more like a cherry than a plum. It is absolutely hardy everywhere. Fruit is one inch in diameter, of bright red color and of good fiavor, very fine for preserves. An early bearer, often bearing fruit the next year after planting. Every back yard should have at least one or two trees.

\section{CURRANTS}

The currant is an indispensible garden fruit for the table and is a money maker, as well. It grows and bears easily in any kind of soil with very little care, but if properly cared for it

Prices, two-year-old plants, each, 25c; 5 for $\$ 1.00 ; 10$ for $\$ 1.90 ; 100$ for $\$ 17.00$. If by parcel

CHERRY. Very large berries on short clusters; a robust, fruitful sort.

LONDON MARKET. Bush vigorous, upright, with perfect foliage. Fruit is large in berries and clusters, dark red and an enormous cropper. Fine for market and table use.

PERFECTION. A cross between Fay and White Grape, retaining the valuable characteristics of both. Beautiful bright red, larger than Fay, holding its size to end of bunch; easy to pick; a superior bearer, less acid and of better quality than any other large currant in cultivation.

WILDER. One of the strongest and most productive. Bunch and berries very large attractive bright red color, and even when dead ripe they hang on bushes in fine condition for handling until very late. A valuable market variety.

WHITE GRAPE. Very large, yellowish white. Fruit excellent quality and valuable for

Perfection Currants.

\section{GOOSEBERRIES}

The gooseberry differs little from the currant in its requirements as to soil and general care. The plant is hardy; a vigorous grower, and free from mildew in our climate. The fruit is used extensively for cooking and canning and is one of the popular berries for pies and jelly.

Prices, each, 25c; per $10, \$ 2.00$; per $100, \$ 17.50$, not postpaid. If by parcel post, add $2 \mathrm{c}$ per plant.

DOWNING. A large and handsome pale green berry of splendid quality for dessert or cooking. The bush is robust and seldom mildews. An excellent sort for family use and quite profitable for the market.

HOUGHTON. An enormously productive and always reliable old sort; of vigorous yet rather slender, spreading growth, not subject to mildew. Fruits of medium size, smooth, pale red; tender and good.

JOSSELYN. Large size, smooth, prolific, hardy and best quality. Least susceptible to mildew, both leaves and fruit, of them all. A wonderful cropper.

OREGON CHAMPION. Berries large, brownish red color, very sweet and fine for table use and pies. Bush a strong grower, healthy, and a very prolific bearer. Fine for market. [56]

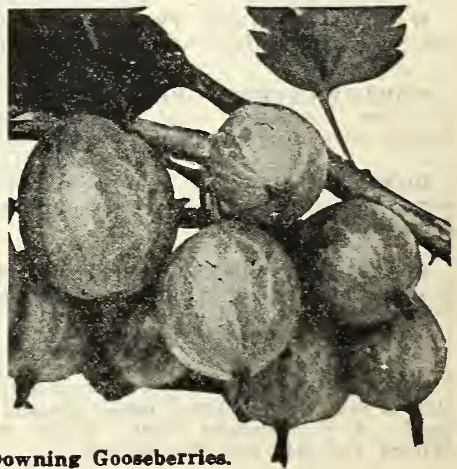

Downing Gooseberries 


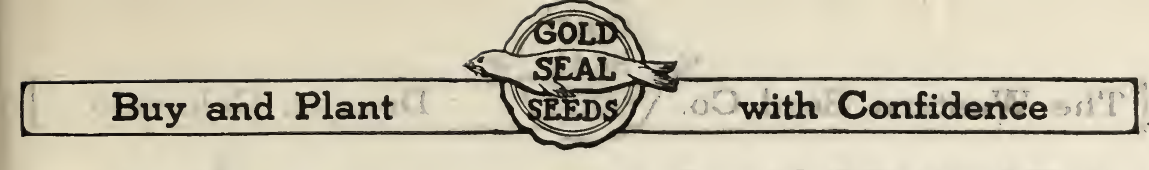

\section{BLACKBERRY PLANTS}

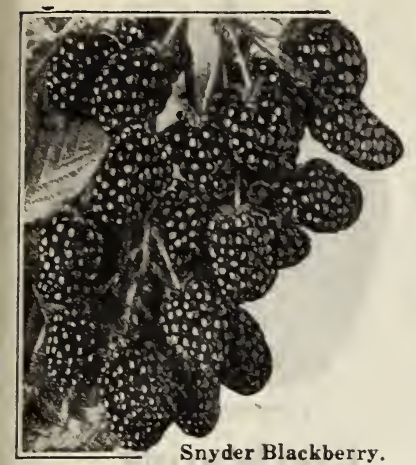

Raspberries and blackberries are very profitable fruits for the home and market. They are of delicious flavor and can be used for the table in many ways.

Prices, each, $10 \mathrm{c}$; per $10,60 \mathrm{c}$; per $100, \$ 4.00$, not postpaid. If by parcel post, add $1 \mathrm{c}$ per plant.

ELDORADO. Of late introduction, being vigorous and hardy in most localities. The berries are large. coal black, flavor sweet and melting and have no hard core. Very firm and therefore an excellent market variety.

SNYDER. Berries of medium size, sweet, melting. Very hardy and wonderfully productive. Valuable for cold climates, as it leads where hardiness is a consideration. Early.

BLOWERS. Claimed to be the hardiest and most productive, and to bring on the market the highest price of all Blackberries. Fruit large size, jet black, of best quality; good shipper; enormous bearer.

EARLY HARVEST. Its earliness, combined with good shipping qualities, makes it a very profitable variety. The fruit is of medium size, firm, and attractive in appearance. Dwarf and compact grower.

\section{BLACK RASPBERRY PLANTS}

CUMBERLAND. "The business Blackcap." It is of wonderful productiveness; producing regularly and uniformly very large crops. In size the fruit is simply enormous, far surpassing any other variety.

GREGG. Early; very large and productive.

KANSAS BLACKCAP. Berries large; heavy bearer.

\section{RED RASPBERRY PLANTS}

Prices, each, 10c; per 10,60c; per 100, \$3.50, not postpaid. If by parcel post, add 1c per plant.

CUTHBERT. A strong grower and very productive, large bright red, fruit firm, of very fine quality. Season medium to late; a good one for market or home use. Is doing well everywhere.

KING. Several of our best fruit growers consider this the best of the red raspberries. It has large and attractive, bright red fruit, of good flavor; ripening with the earliest and firm enough to keep for some time; in hardiness and productiveness all that could be desired.

LOUDEN. This variety is a mar-

LOUDEN. This variety is a mar-
vel of productiveness and hardy to the tips of its shoots. Its large and beautiful, rich, dark crimson fruits are of good flavor; ship better and hang longer after ripening than thase of any other variety.

MARLBORO. A profitable early market berry, with large crimson fruits of good quality and firmness. This variety is very hardy and well suited to the North.

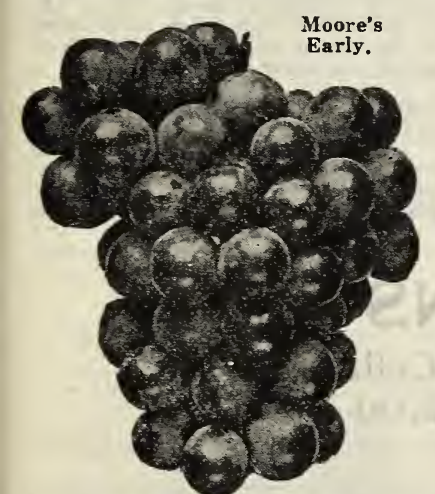

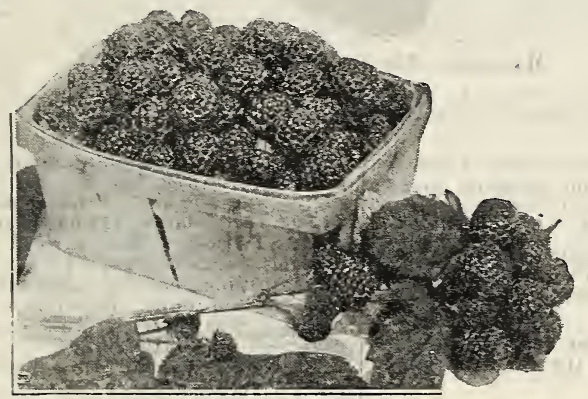

Cumberland Black Raspberries.

\section{HARDY GRAPE VINES}

Everyone should plant grapes in the home garden. No part of the fruit garden gives you greater pleasure and more satisfaction than the vineyard. Grapes are easy to grow and do well in any ordinary soil. They can be trained over frames, trellises or doorways and are ornamental as well as useful. Make your own grape juice.

CONCORD (Black). The fine old market leader, with large, handsome clusters of big, luscious grapes. Entirely hardy, productive and reliable: succeeds well over a great extent of country.

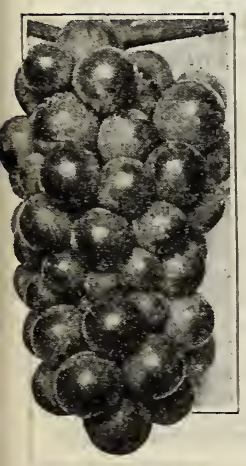

Wyoming Grapes.
MOORE'S EARLY (Black). Clusters of medium size; berries large, round, black, with heavy blue bloom. Extra early, successful in the West.

NIAGARA (The White Concord). One of the leading white sorts, bunch large, compact; berry large yellowish white.

WORDEN (Black). Resembling the Concord, but larger and better quality, and five to ten days earlier. A vigorous, hardy, and very productive grower.

WYOMING (Red). One of the most beautiful of the red or amber grapes, brighter colored than Delaware, earlier, nearly twice as large; flesh tender, juicy, sweet, with a strong, native aroma. The vine is hardy and healthy, with thick, leathery foliage. The best of the red grapes for early market.

\section{Prices of Grapes}

Concord-Each, $15 \mathrm{c}$; per 10, $\$ 1.25$; per $100, \$ 10.00$.

Other Varieties-Each, 30c; per $10, \$ 2.50$; per $100, \$ 18.00$.

Not postpaid; if by parcel post, add $2 \mathrm{c}$ per plant.

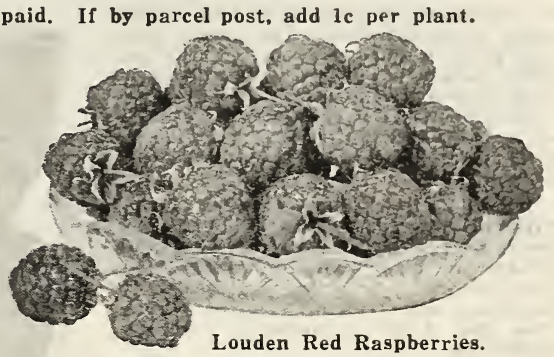

\section{EVERBEARING} RASPBERRIES

ST. REGIS. Berries bright crimson, of large size, fine and meaty, with a rich, luscious, true raspberry flavor. It is wonderfully prolific, the fruit beginning to ripen with the earliest and continuing well into October. The canes are stocky, of strong growth, with an abundance of dark green, feathery foliage. Prices, each, $10 c$; per $10,60 c$; per $100, \$ 3.50$, not postpaid. If by parcel post, add 1c per plant.

\section{DEWBERRIES}

LUCRETIA. In size and quality this lowgrowing or trailing blackberry equals any of the upright sorts. Its berries ripen before raspberries are gone, are large, soft, sweet, and luscious throughout, with no hard core. The vine is perfectly hardy, healthy, and exMangly fruitful, with large showy blossoms. slopes, where there is no room for other becky Prices, each, 10c; per 10,65́c; per $100, \$ 4.00$, not postpaid. If by parcel post, add lc per plant.

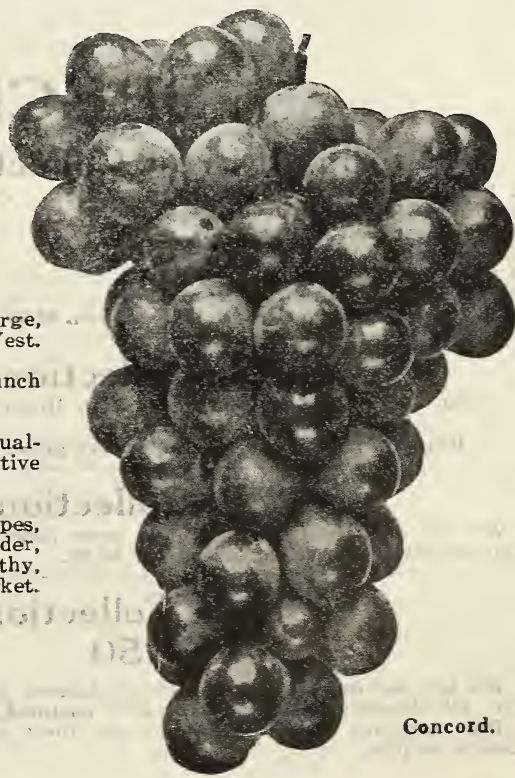




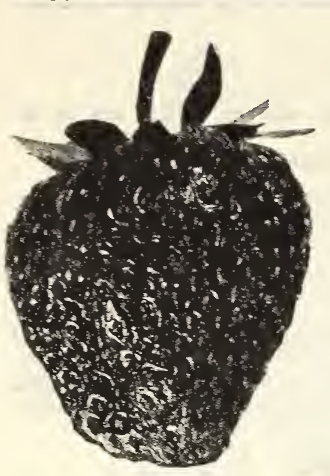

Hood River.

\section{Strawberries}

CULTURE. A good many people overlook the strawberry, thinking the plants demand too much care, but this is not true. Strawberries will succeed in any soil that is adapted to ordinary farm or garden crops. For held culture set in rows three feet apart, 18 inches in rows; for garden, 15 inches each way, leaving pathway every third row. The ground should al sas or kept clean and well cultivated. In Winter a covering of leaves, until the ground is frozen, or so deep as to smother plants, and remove covering before growth starts in the Spring.

\section{Standard Varieties}

AROMA. A large, bright scarlet berry of a roundish, conical shape. Not quite as large as the Fremont Williams. It is very productive, a fine canning and shipping berry.

FREMONT WILLIAMS. A new, large, late season strawberry that has proven itself for western and more particularly the Denver market. The proven itself for western and more

As a shipper, it is hard to beat on account of its firmness. The plants make a large bush and winter better than any other variety known. On account of it good keeping quality it makes an excellent shipper. If you want a large, well. shaped strawberry that will outsell anything on the market, don't overlook this wonder.

DR. BURRILL (The Million Dollar Strawberry). The Gem of Perfection. Berries large, dark red, of the best quality and uniform in size and shape. This nuw variety is a strong fertilizer. It blooming and fruiting season is long and it is a wonderful producer midseason.

HOOD RIVER. This variety has won ureat favor out West, and just before any of our home-grown berries are ready our market requires a number of cars of Hood River berlies from Oregon, and it was through these shipments that our trade became acquainted with the berry. The Hood River berry produces dark red fruit, very heavily meated, and instead of a pinkish white color it is a dark red. Our stock was secured irom the best berry men

RIDGEWAY. A very large, midseason, handsome berry, of heavy yielding power; the berries are very solid and stand shipping great distances; very highly flavored and juicy; excellent for preserves. A dandy for either the home garden or the market.

SENATOR DUNLAP. A very hardy midseason variety that produces a heavy yield of large, richly colored strawberries that command good prices on the market. The plant makes a very heavy foliage and is a good keeper through the Winter.

Prices, postpaid: 25 for $40 \mathrm{c}$; 50 for $60 \mathrm{c} ; 100$ for $90 \mathrm{c}$. If by express at buyer's expense, 25 for $30 c ; 50$ for $50 c ; 100$ for $80 c$. Not postpaid, 1000 for $\$ 6.50$.

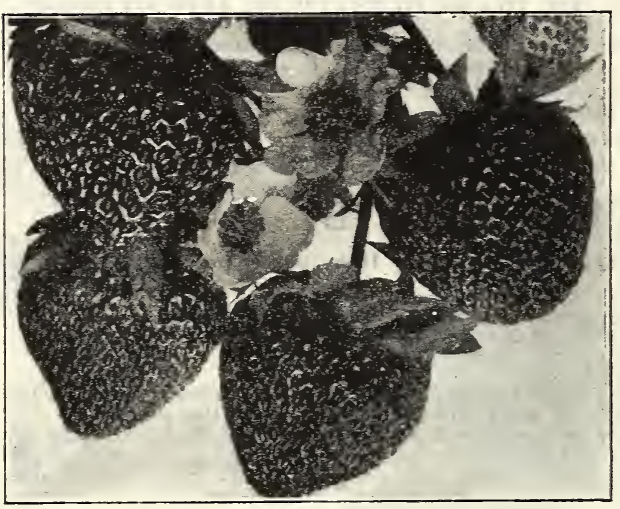

Best Everbearer.

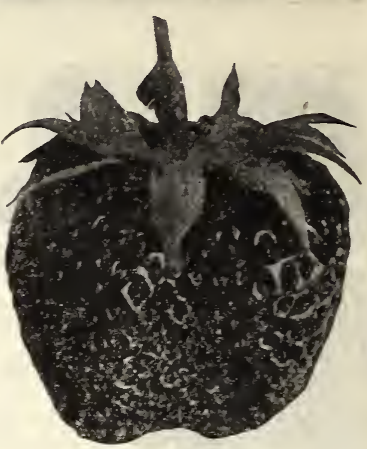

Fremont Williams.

\section{Everbearing} Strawberries

This wonderful strawberry was obtained by cross-pollinating the wild ving alpine sorts with the stand ard varieties, and yields continuously from the latter part of May until frost destroys the leaves, and many times berries may be picked in the snow. The plants bear the same year they are started, but if a large amount of late berries are desired it is better to pinch blossoms which causes the heaviest crop to come on during September and October.

It is best not to trim off any of the runners or shoots, just allow them to run and bloom, and during the hot summer months they require a little additional water and some cultivation to get the best results.

Get your order in early. Shipments will be made at any date you desire. Have your ground ready and we will forward the plants so you will receive them in nice fresh condition well packed, just when you are ready for them.

PROGRESSIVE. This is the old variety of everbearing which still holds a prominent place among the everbearing strawberries. It is a strong grower, has dense foliage, fruit medium and dark colored of the finest flavor. Price, 1 dozen, $25 \mathrm{c} ; 50$ plants, $\$ 1.00 ; 100$ plants, $\$ 1.50$ : 1000 plants, $\$ 12.00$, postpaid.

MASTODON. This variety is a great improvement in the Everbearing Strawberries. It is really a wonderful Berry. It is the most prolific, bearing abundance of largest fruit from early Sum mer to late Fall. Regardless of your past experience with Everbearing Strawberries, we recommend you plant Mastodon, which is different and satisfactory.

Last Fall we had an opportunity. to see Mastodon grown alongside of almost every variety of Everbearing Strawberries. There simply was no comparison as to yield, size, flavor and firmness of fruit. Since seeing this comparison, we have tinued offering all other varieties.

Price: 25 plants, $\$ 1.00 ; 50$ plants, $\$ 1.75 ; 100$ plants, $\$ 3.00 ; 500$ plants, $\$ 11.00$.

\section{SPECIAL COLLECTIONS}

\section{Small Fruit Collection}

6 Red Raspberry, Cuthbert

3 Grape, Moore's Early

6 Blackberry, Snyder

2 Gooseberry, Downing

25 Strawberry, Dunlap or Hood Rive

Regular price, $\$ 4.45$; cost you $\$ 3.50$, postpaid.

\section{Shrub Collection}

1 Golden Bell 1 Snowberry 4 Van Houttei Spirea 2 Lilacs

Regular price, $\$ 8.00$, postpaid; our price, $\$ 6.50$, postpaid.

\section{Rose Collection}

We will send postpaid, any five roses listed at $60 \mathrm{c}$ or $65 \mathrm{c}$ each, your selection, for $\$ 2.75$, or ten for $\$ 5.00$.

\section{Dahlia Collection $\$ 1.50$}

We are making a special offer of thirteen good roots, our selec. tion, all different colors, no two alike, postpaid, $\$ 1.50$.

This collection contains some of our finest varieties on which we have a surplus.

\section{Dahlia Collection $\$ 2.00$}

We will send, postpaid, any ten, your selection, of our 25 c dahlias, for $\$ 2.00$, postpaid.

\section{FREE-TO EVERY CUSTOMER-FREE} FLOWER SEEDS, DAHLIAS AND GLADIOLI

Everyone is fond of flowers, and every farm, garden or ranch should have them about the house. So we have made up selection of flowers that will bloom all season and produce an abundance of beautiful flowers. This collection consists of six packages of Flower Seeds, ensy to grow and all different, three strong Dahlia roots, different colors, and 12 fancy Groff's Strain Gladielus Bulbs. The above six packages of flower seed will be sent to any of our customers free, sending us an order for flower or vegetable seeds that will amount to $\$ 2.00$, and if your order is $\$ 4.50$ we will include the Dahlias. If your order is $\$ 7.00$ or more, we will send the whole collection of Flower Seed, Dahlias and Gladioli.

This offer is on vegetable and flower seed, not field seed or

poultry supplies, etc.
NOTICE. Some of our customers do not have the time to spare about the flower garden and others are unable to provide water for flowers, so do not care for the free collection, and we are sending it only upon request. Those who wish it must ask for it. 


\section{Deciduous Ornamental Trees}

Many people are realizing nowadays that by expending a little time and study they can have well kept and attractive looking grounds, adding to the beauty and comfort of the home and increasing the value of the property. There is an ornamental deciduous tree for almost every purpose, whether for shade, for hiding objectionable sights, or for beauty or utility. Our list comprises all those varieties which are well sights, or for beauty or utility. Our list comprises all those varieties which are well
adapted to our western climate. You will find many interesting trees, suitable for your individual tastes.

Note: We divide the ornamental trees into two classes-those suitable for street planting, "Class A" : those suitable for lawns, "Class B." Those that can be used for either are marked "AB." For large lawns many of the "A" class are desirable; note the letter after each variety.

BIRCH, AMERICAN WHITE (A). A medium sized tree with smooth white bark and handinme foliage. Thrives well even in poor and dry soils. Very attractive and crnamental. Price, ea:h, $\$ 1.50$, not postpaid.

AMERICAN ELM (A). 6 to 8 feet. Easily distinguished by its wide, arching top, vase-like form and pendulous branchlets. Next to the oak, this is the grandest and most picturesque of American trees. Yellow or brown in Fall. Price, each, \$1.10; 10 for $\$ 9.50$, not postpaid. AMERICAN LINDEN (AB). A stately tree, with large, shining cordate leaves.
Valuable for its beautiful white wood; flowers in July. A valuable lawn tree and should he used for this purpase. Price, each, $\$ 1.60 ; 10$ for $\$ 15.00$.

CATALPA SPECIOSA (AB). A handsome large foliaged tree. It is very hardy and a ranid grower: foliage heart shaped and dark green. The flowers are two inches in diameter and come in large pyramidal panicles, color white, striped yellow, dotted reddish and violet. Blooms early in Summer, followed by long seed pods in Autumn. $A$ fine tree for the lawn. 8 to 10 feet. $\$ 1.00$, not postpaid.

CATALPA BUNGEI (Umbrella Catalpa) (B). Grafted on stems five feet high, it makes an umbrella-shaped top without pruning. Perfectly hardy, and flourishes in almost all soils and climates. Leaves large, glossy, heart-shaped, deep green, lying almost all soils and climates. Leaves large, glossy, heart-shaped, deep green, lying like shingles on a roof: always making a syn
trees: desirable for lawn, park and cemetery planting. Price, each, $\$ 1.50$; per 10 \$13.50, not postpaid.

CRAB, BECHTEL'S DOUBLE FLOWERING (B). Makes a medium sized tree; perfectly hardy, does well in a medium dry soil. Binms appear to be delicate pink. nerfectly double small roses of delicious fragrance. The only sweet-scented double Each, \$2.00.

RUSSIAN OLIVE (AB). 5 to 6 feet. A very hardy and handsome species that in some sections forms a small tree, 8 to 12 feet high. The leaves are particularly handsome, willowlike and a rich silvery white. The flowers are small, golden yellow and very fragrant, followed by yellow fruits, which are covered with silvery scales. which are covered with silvery scales. Blooms in June. $\mathrm{N}$
$\$ 1.25$; per $10, \$ 10.00$.

GOLDEN RUSSIAN WILLOW (B). At the present time one of the most planted of all willows and a very important tree, both from an ornamental and economical standpoint. It makes a round top tree of symmetrical form. One of its strongest ornamental features is the bright clear golden yellow bark which offers a contrast wherever used. Not postpaid: Each, 75c: per $10, \$ 6.50$.

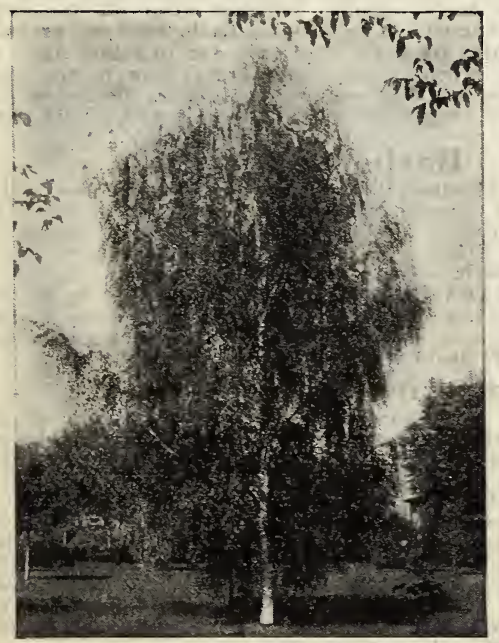

Cut-Leaved Weeping Birch.
PUSSY WILLOW. A small tree with upright branches. Catkins very numerous, handsome in flower: greatly esteemed by reason of its extreme earliness. 5-6 ft. $\$ 1.00$.

LARCH (Larix Europea). A lofty, rapid growing, pyramidal tree, with delicate light drops its foliage in the Fall. Very beautiful and fine for specimens on the lawn. 3 to 4 feet. $\$ 1.75$ each, not postpaid.

BLACK WALNUT. A splendid shade and ornamental tree and the best tree for Colorado. It should be planted more in this country. Because of its deep tap root, only small sizes should be set. 6 to 8 feet. $\$ 1.25$ each; per $10, \$ 10.00$, not postpaid.

MOUNTAIN ASH (European) (B). Hardy tree; head dense and regular, beautiful fernlike green foliage: covered from July tili Winter with clusters of bright, red berries. The comtrees that grow. Not postpaid : Each, $\$ 1.00$; per 10, $\$ 9.00$.
the

OAK, RED ( $\mathrm{AB})$. A large native tree with deeply cut, bright green leaves which turn purplish crimson in Autumn. 5 to 6 feet. $\$ 2.00$ each.

SOFT or SILVER MAPLE (A). 6 to $8 \mathrm{ft}$. A hardy, rapid-growing native tree of large size. Valuable for producing a quick shade. Excellent for street planting. Price, each, $\$ 1.25$; per $10, \$ 10.00$, not postpaid.

NORWAY MAPLE (A), 6 to 8 feet. Native of Europe; a large, handsome tree, with broad, deep green shining foliage. Very desirable for street, park or lawns. The Norway Maple characteristically makes the roundest head; is colored the deepest coolest green : and furnishes the densest shade of the entire list of good trees. Price, each, $11.75 ;$ per $10, \$ 15.00$, not postpaid.

SUGAR or HARD MAPLE (A). 6 to 8 feet. This tree is chieftain of its clan; straight, spreading, symmetrical, of rrand proportions, often 40 feet in height, and longer lived than most men who plant it. It grows well in all except damp, soggy soils, and roots deeply. most men who plant it. It grows well in all except damp, soggy soils, and roots deeply, allowing grass to grow close to its trunk. Its bold leaves have very rich
clear yellow and scarlet. Price, each, $\$ 2.00 ;$ per $10, \$ 18.00$, not postpaid.

WEIR'S CUT LEAVED SILVER MAPLE (AB). 6 to 8 feet. One of the best cut or dissected leaved trees, of rapid growth. Not pestpaid: Each, $\$ 1.50 ;$ per $10, \$ 13.50$.

SCHWEDLER'S MAPLE (AB). The beautiful leaves attract attention at all seasons, but are especially fine in Spring when their gleaming red and purple contrasts brightly with the delicate green of nther trees. In midsummer they are purplish green, in Autumn golden yeilow. 5 to 6 feet. $\$ 3.00$ each.

BOLleana POPLAR (AB). 6 to 8 feet. Similar to Lombardy in habit, but hroader with leaves glossy green ahove, silvery beneath. Each, $\$ 1.50 ;$ per $10, \$ 12.00$, not postpaid.

CAROLIN A POPLAR (A). 8 to 10 feet. Unexcelled for quick growth and effect. Its rapid growth gives an air of luxuriance to places where other trees appear starved. Showy and cheery from the constant movement of its glossy, silver-lined leaves, yet always casting a dense, cool shade. Not postpaid: Each, $\$ 1.00$; per $10, \$ 9.00$.

NORWAY POPLAR. Makes a thick, broad-topped shading tree of quick growth and great hardiness. Broad, triangular leaves with finely scalloped edges, smooth dark green. 8-10 ft., $\$ 1.00$ each; per $10, \$ 9.00$.

LOMBARDY (AB). 8 to 1 feet. Remarkable for its picturesque tall, spirelike form desirable as quick growing street trees. Not postpaid: Each, $\$ 1.25 ;$ per $10, \$ 11.00$.

SILVER LEAVED POPLAR. Large growing: leaves dark green on upper side, silver underneath. Each, $\$ 1.00 ; 10$ for $\$ 9.00$, not postpaid.

\section{Weeping Deciduous Trees}

CUT LEAVED WEEPING BIRCH (B). One of the most elegant of all weeping trees. Its tall, slender, yet vigorous growth, with graceful drooping habit, silvery white bark and
delicate cut leaved foliage makes it one of the most attractive trees. It is especially ornamental. 6 to 8 feet. Price, $\$ 2.50$ each, not postpaid.

WISCONSIN WEEPING WILLOW. Of drooping habit and beautiful form. The most hardy of all Weeping Willows. 5-6 ft.. $\$ 1.00$ each.

WEFPING WILLOW (Niobe) (B). A handsome tree, slender leaves, green above, silvery beneath. The twigs and bark tinged dark red. 5 to 6 feet. $\$ 1.00$ each. 


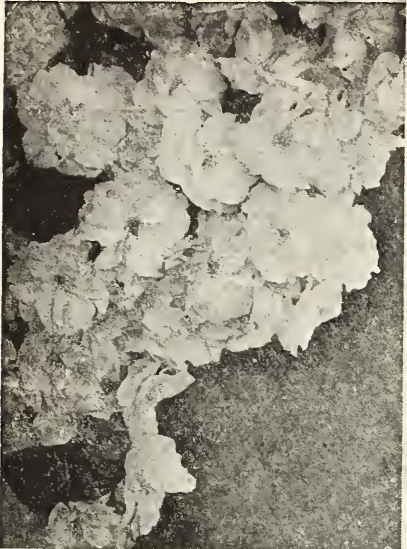

Flowęring Almond.

\section{Elder - Sambucus}

Although the elders are attractive in flower and fruit, they are chiefly grown for their beautiful leaves, which make admirable fillers among other shrubs. Being rather tall growing and of robust habit, their growing and of robust habit, their grounds, screens, or tall hedges.

AMERICAN ELDER (Canadensis) (L). Immense flat topped cymes of white flowers in early Summer, fol luscious black fruits- the source of Mother's "Elderberry Pie." 3 to feet. Each, 60c, not prepaid.

CUT-LEAVED ELDER (Canadensis Acutifolia) (L). One of the best cutleaved shrubs. 3 to 4 feet. Each, 60c, not prepaid.

GOLDEN ELDER (S. Nigra Aurea) (L). Contrasted with other shrubs, the golden yellow leaves of this European elder gives heightened effects in tone and color. Flowers white in flat topped cymes. Grows naturally 10 to 15 feet but can be pruned into neat, compact little bush. Each, 60c, not prepaid.

\section{Feather Bush - Tamarix}

AMURENSIS (L). The hardiest variety. The loose, rose colored flowers are borne along its branches, the foliage is light and feathery. If cut back each Spring before the growth starts, the bush will be more graceful during the season. May be planted on moist ground as well as dry. 3 to 4 feet. Each, $60 \mathrm{c}$, not prepaid.

\section{Golden Bell}

FORSYTHIA SUSPENSA (M). This splendid old shrub lights un the garden with glinting masses of yellow early in the Spring before the leaves appear. Has a drooping habit. 3 to 4 feet. Each, 60c, not prepaid.

\section{Honeysuckle - Lonicera}

The upright honeysuckles have bright and pretty fragrant flowers, followed by showy berries that last through the Fall. Make very desirable and attractive shrubs.

WHITE (M). Flowers blush white, 3 to 4 feet. Each, 60c, not prepaid.

ROSE or PINK (M). Deep rose pink flowers, 3 to 4 feet. Each, 65c, not prepaid.

RED (M). Blossoms are a very pronounced red; one of the best honeysuckles. 3 to 4 feet. Each, 65 c, not prepaid.

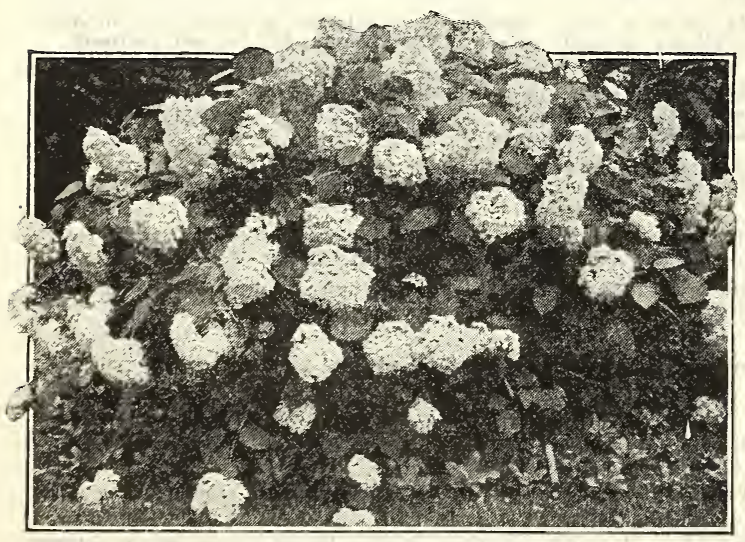

Hydrangea-Hills of Snow.

\section{Flowering Almond}

ALMOND (M) Spring flowering shrubs, blooming very gaily before the leaves appear. Their growth is dwarf, bushy, and com pact; slender branched; when in bloom completely hidden by beau iful, double flowers of rose or white, snuggling tight to the twigs.

\section{Butterfly Bush}

BUDDLEIA (Butterfly Bush) (S). A most beautiful shrub that produces long graceful stems, which terminate in tapering panicles of beautiful lilac colored flowers. It is a rapid grower and will throw out as many as fifty spikes a season. The shrub will freeze down in Colorado. while hardy, it is best to cover the roots with leaves or manure, to insure a heavier growth the next season. It not prepaid.

\section{Dogwood}

CORNUS SIBIRICA ALBA (M). Red stemmed. Clusters of fine white flowers, succeeded by a fall crop of ornamental berries; stem

CORNUS STOLONIFERA, LUTEA (Flaviramea). (M). Yellow. stemmed. Clusters of white flowers, stems, and branches are yellow. Each, $60 \mathrm{c}$, not prepaid.

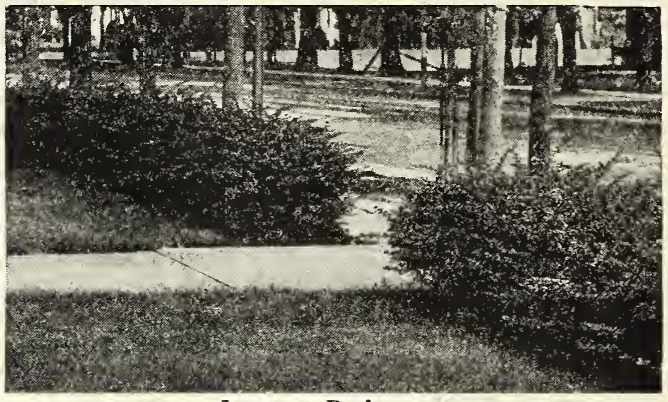

Japanese Barberry.

\section{Rose of Sharon}

HIBISCUS: ALTHEA (S) One of the best known shrubs with handsome plain and variegated foliage bearing large single and double flowers in red, pink, and white in August and September. They are very hardy, easily cultivated and will bloom until their growth is cut off by frost. 3 to 4 feet. Each, $60 \mathrm{c}$, not prepaid.

\section{Hydrangea}

ARBORESCENS GRANDIFLORA or HILLS OF SNOW (S). This hardy American shrub grows 4 to 6 feet high and is one of the finest of this class of plants. The blooms are of largest size, of pure snow of thite and the foliage is finely finished Blooms after all the early shrubs, from June until August. 2 to 3 feet. Each, 80c, not prepaid.

PANICULATA GRANDIFLORA (S). A good one to follow Hills of Snow, blooming profusely when other shrubs are failing in the Fall. Blossoms open white, assuming rose and bronze tints on the sunny side and drooping gracefully of their own weight. 2 to 3 feet. Each, 80c, not prepaid.

\section{Barberry}

JAPANESE (Berberis Thunbergi) (D). A very popular low hedge plant of great hardiness; flowers followed by bright red berries that remain on plant until February. Foliage small dark green, turning to brilliant colors in Fall. Effective for use in edging shrubbery or in masses. $1 \frac{112}{2}$ to 2 feet. Each, 50c; 10 for $\$ 4.00$, not prepaid.

NEW RED-LEAVED JAPANESE BARBERRY. Similar in all respects to the green-leaved, but the foliage is of a rich, lustrous, bronzy red. It should be planted in a sunny exposure to bring out and retain its full red color. 18 to 24 inches, $\$ 1.00$ each, not prepaid.

\section{Flowering Quince}

(Pyrus Japonica) (S). Very ornamental in early Spring, as its bright scarlet flowers completely cover the branches before the leaves are formed. Makes a good hedge. 2 to 3 feet. Each, 75c, not prepaid.

\section{Flowering Plum}

PURPLE-LEAVED (Pissardi). A small treelike shrub. The young branches are a dark purple; the leaves when young are lustrous crimson changing to dark purple. In early Spring before the leaves unfold the tree is covered with flowers. Each, $\$ 1.00$ : 10 for $\$ 8.00$, not prepaid.

DOUBLE-FLOWERING (P. Triloba). A beautiful small tree or shrub of fine habit, with elegant, double, rosy flowers, set very closely on slender branches. $\$ 1.00$ each, not prepaid. 


\section{Lilacs}

LILAC, COMMON PURPLE (Syringa Vulgaris) (M). The lilac is familiar to everyone, with its fine, heart-shaped foliage and splendid panicles of typical lilac flowers, which are of delightful fragrance and borne in hybrids, of which it is the parent. Each, 75c, not prepaid.

LILAC, COMMON WHITE (Syringa Vulgaris Alba) (M). Similar to the former, with pure white, very fragrant flowers and handsome foliage. Each, $75 \mathrm{c}$, not prepaid.

LILAC, PERSIAN (Syringa Persica). This variety has smaller leaves than the common lilac. Its branches are slender and straight; the bright purple flowers are borne in loose panicles in a fine graceful form. 3 to feet. $\$ 1.00$ each, not prepaid.

LILAC, HUNGARIAN (Syringa Josikaea). A fine distinet species of treelike growth, with dark shining leaves and purple flowers. It blooms a month later, after all other lilacs are done blooming. Esteemed for its fine habits and foliage. 2 to 3 feet. $\$ 1.00$ each, not prepaid.

\section{Shrub Roses}

The roses we mention here grow too large to be planted with other bush roses and should be used only in connection with shrubbery or as specimens on lawns. Their beautiful blooms, ornamental foliage, bright berries, brilliant autumn colors and picturesque habit of growth make them very desirable for every garden of any size.

HUGONIS (Chinese Briar). A striking attractive new shrub, with clean helthy foliage of the briar trpe. When in bloom it is a shimmering mound of gold and very fragrant. A most decorative shrub from early Spring until late in Fali. $75 \mathrm{c}$ each.

F. J. GROOTENDORST. This is a Polyantha-Rugosa and new in its class. It has continuous blooming qualities, is of rugged hardy growth, with foliage shiny and leathery. The blooms come in clusters of a rich, red color from early Summer until Fall. $75 \mathrm{c}$ each.

ROSA RUBIGINOSA (English Sweet Briar). A tall grower with arching branches. Bright pink single flowers, followed by red berries that are retained all Winter. Foliage and flowers both have a rich, spicy ragrance. $75 \mathrm{c}$ each, not prepaid.

HANSA. Valuable for its great hardiness and vigor, flowers large and double, of a reddish violet color, foliage always free from insect pests. $75 \mathrm{c}$ each.

PERSIAN YELLOW. Lovely, golden yellow, semi-double flowers. $75 \mathrm{c}$ each.

\section{Snowball}

VIBURNUM OPULUS STERILE. A grand hardy shrub. The flowers appear in numerous compact balls in the Spring. Well known and each, not prepaid.

VIBURNUM DENTATUM (L). A perfect upright growing shrub. with heart-shaped leaves, bright green in Summer, changing later to a rich purple and red. The handsome creamy-white flowers are followed by blue-black berries. 3 to 4 feet. $75 \mathrm{c}$ each, not postpaid.

VIBURNUM OPULUS (High Bush Cranberry). (L). The well known variety in old gardens. Grows 8 to 10 feet tall, bearing its balls of white flowers in great profusion in May and June, followed by scarlet fruits in clusters. 3

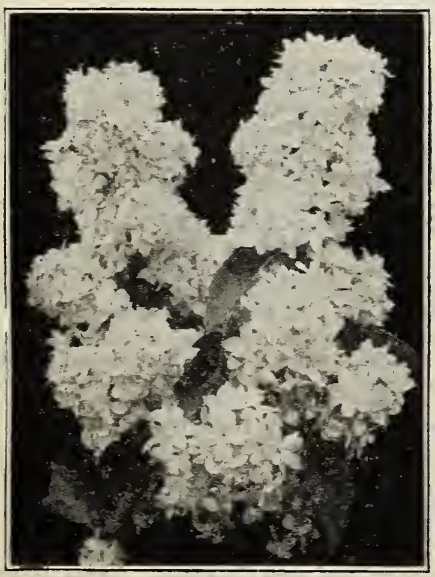

Lilac.

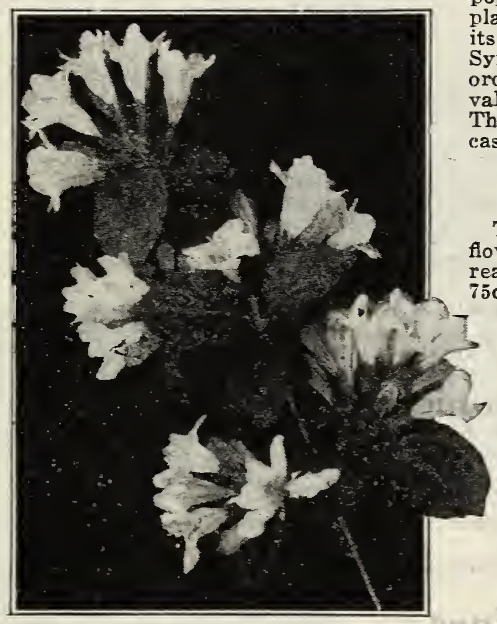

Weigela.

\section{Spirea}

All of the spireas bloom with a riotous extravagance which makes them quite striking. Their individual style, color, and habits of growth differ so markedly that a collection of grorietios will inme bly the varieties will insure bloom the entire sea

ANTHONY WATERER. Dwarf, bushy, spreading type, with large, deep red flowers. Blooms freely throughout the Summer until planting

BILLIARDI. A strong grower; dull green foliage, dense panicles of bright pink flowers. Blooms during July and August and occasionally during the Fall. Each, 65c, not prepaid.

THUNBERGI. This Japanese species forms a dense fluffy bush, 3 to 5 feet high, with feath ery foliage of yellowish green, changing in Autumn to bright red and orange. Flowers borne the entire length of the stem. One
the earliest to bloom. $60 \mathrm{c}$ each, not prepaid.

PRUNIFOLIA, TRUE BRIDAL WREATH (M). Beautiful white flowers, double and very profuse. Foliage scarlet in Autumn. Each, 75 c, not prepaid.

VAN HOUTTEI (M). This is one of the finest ornamental shrubs in our whole collection, and much used in all good landscape work. Its branches droop with singular grace under their white burden of flowers in late Spring. Each, 50c, not prepaid.

\section{Snowberry}

\section{Mock Orange}

(Philadelphus Coronarius) (L). The is undoubtedly one of the best known and most rubs, and, in spite of the great number of new

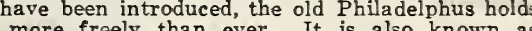
ome localities. The shrubs are usually tall, vigwers, with large foliage and flowers, and so are are very sweet-scented, milk-white, in most

\section{Philadelphus Virginal}

YMPHORICARPOS RACEMOSUS (White Snowberry) ). Inconspicuous rose-colored flowers in June and July;

MPHORICARPOS VULGARIS (Indian Currant: ach, $65 \mathrm{c}$, not prepaid.

\section{Sweet Scented Shrub}

This is one of the most desirable shrubs. The wood is fragrant. Flowers are of a rare chocolate color, having an exquisite pineapple out the Summer. Each, 75 , not prepaid.

\section{Sumac}

Nothing will make a more attractive corner in the garden than a large clump of Sumac. The foliage is very graceful, on some varieties fernlike, and every lover of nature thrills at the gorgeous color display of its foliage in

RHUS GLABRA LACINIATA (S). A variety with deeply cut fernlike foliage, which
turns crimson in the Fall. 3 to 4 feet. $65 \mathrm{c}$ each, not prepaid.

STAGHORN SUMAC (Rhus Typhina) (L). A large shrub or tree, brilliant foliage and
scarlet fruit in Autumn. 3 to 4 feet. Each, 75 c, not prepaid.

\section{Weigela}

Beautiful shrubs that bloom in May, June, and July. The flowers are produced in so great profusion as to almost entirely hide the foliage.

DIERVILLA (Eva Rathke) (M). A charming new weigela ; flowers brilliant crimson: a beautiful, distinct, clear shade. 3 to 4 feet. Each, $90 \mathrm{c}$, not prepaid.

ROSEA VARIEGATED (S). An exceedngly pretty variety, the variegation being very distinct. 3 to 4 feet. Each, 75c, not prepsid. 


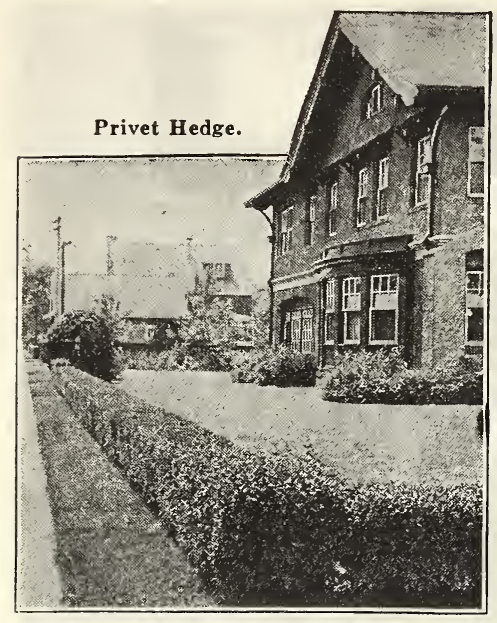

\section{Privet - Ligustrum}

Besides being one of our best hedge plants, various species of privet form interesting groups on the lawn.

They are almost evergreen; of dense compact habit. The flowers are fragrant, and are followed by pretty sprays of different colored berries.

AMOOR RIVER NORTH (L. Amurense) (M). Of similar form and habit to the California type, not so shiny, but reputed to be hardier. 18-24 inches, per $10, \$ 1.25$; per $100, \$ 10.00$, not prepaid.

IBOTA (Chinese Privet) (M). Spreading and tall growing, the hardiest of the group. Color grayish green, fruits black. $18-24$ inches, per 10 , $\$ 1.50$; per $100, \$ 12.00$, not prepaid. IBOLIUM. This is a cross between Ibota and California Privet. The foliage resembles that of California, but Ibolium is much hardier, more branching and more spreading in growth. It drops its foliage completely in Winter. Very popular privet. 18 to 24 inches. Per 10, $\$ 2.00$; per 100 , $\$ 15.00$, not prepaid.

VULGARIS (English Privet). Grayish green leaves, white flowers and black fruit. Very hardy. $11 / 2$ to 2 feet. Per $10, \$ 2.00$; per $100, \$ 16.00$, not prepaid.

\section{HARDY CLIMBING VINES}

Plant more vines and plenty of them. There is hardly anything that will add so much attractiveness to the home as some well selected vines. They give an air of homelike seclusion, which is very pleasing. The following list embodies all popular varieties for all purposes.

\section{Ivy}

AMERICAN IVY; VIRGINIA CREEPER; WOODBINE. Fine for covering porches, ver. andas or trunks of trees. Very popular because it is a very hardy and rapid grower. It must have some kind of netting or framework on which to cling. Price, 2-year-old: Each, 35c; 5 for $\$ 1.50$, postpaid.

ENGELMANNI. This is the most satisfactory for our western country as it is very hardy; a rapid grower: more beautiful than the American Ivy: it requires no support on such surfaces as stucco walls or rough brick but on very smooth surfaces it does not cling. Price, 2-year-old roots: Each, $35 \mathrm{c} ; 5$ for $\$ 1.50$, postpaid.

BOSTON IVY. This is the variety that clings tightly to all surfaces whether smooth or rough. Leaves are deep green, smaller than the other ivies; however, it is not so popular in our western country as it grows very slowly in this climate. Price, 3-year-old plants: Each, 75c; 5 for $\$ 3.00$, postpaid.

\section{Clematis}

The finer varieties of clematis are today the most showy and effective of all the hardy climbing vines known. so far as richness of color and elegance of form of flower is concerned. Their exceedingly rapid growth makes them very valuable for pillars and trellises, pegged down for rockwork, old trees, and stumps.

JACKMANI. The flowers, when fully expanded, measure 5 to 6 inches in diameter, of intense violet purplish color, with a rich velvety appearance; bloom continuously until frost. Each \$1.00.

PANICULATA (Sw eet-Scented Japan.) Are of very rapid growth, quickly covering trellises and arbors with handsome, clean, glossy foliage. The flowers are medium sized, white in color, very fragrant and of a shiny appearance, blooming in August and September. Each, 50c.

MADAME EDOUARD ANDRE. Flowers large, of a beautiful velvety red, very free flowering and a continuous bloomer. Each, $\$ 1.00$.

HENRYI. Large, white flowers. Two-year-old roots. Each, \$1.00.

RAMONA. A strong rampant grower and very hardy. It is a free and perpetual blooming variety. The color of the flower is deep sky blue, and the largest of any kind. Each, \$1.00.

\section{Honeysuckle - Lonicera}

Their vining qualities are all that can be desired, but the delightful fragrance of their flowers makes the strongest bid for favor. The honeysuckle perfume is loved throughout the world.

BELGICA (Monthly Fragrant). One of the prettiest, with numerous sprays of red and yellow. Each, 60c; per 10, $\$ 5.50$.

HALLIANA. Color, an intermingling of white and yellow; extremely fragrant and most satisfactory. Each, 50c; per 10, \$4.50.

SEMPERVIRENS (Scarlet Trumpet Honeysuckle). Trumpet-shaped flowers of bright scarlet. Each, 50c; per 10, $\$ 4.50$.

\section{Assorted Vines}

CHINESE MATRIMONY VINE (Lycium Chinense). A general utility hardy climbing vine that will overcome any obstacle to growth and flourish everywhere. Every new shoot produces handsome

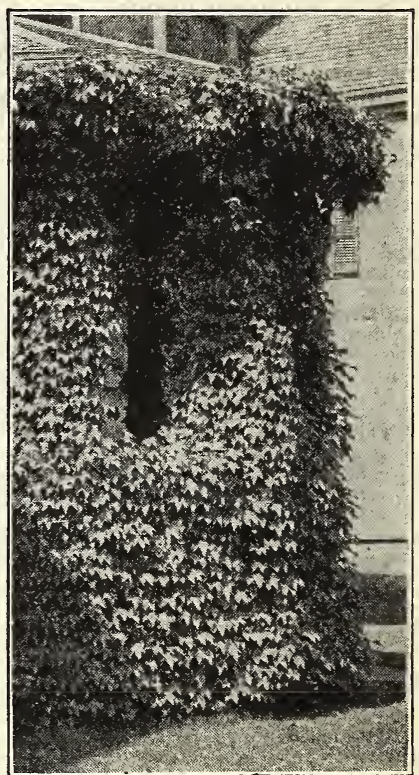

Boston Ivy.

CINNAMON VINE. Well flowers and later a prodigious crop of scarlet berries nearly an inch long. Each, 50c; 10 for \$4.00. known hardy climber, quick grower, with glossy heart-shaped leaves and sweet-scented flowers. $15 c$ each ; \$1.50 per doz., postpaid.

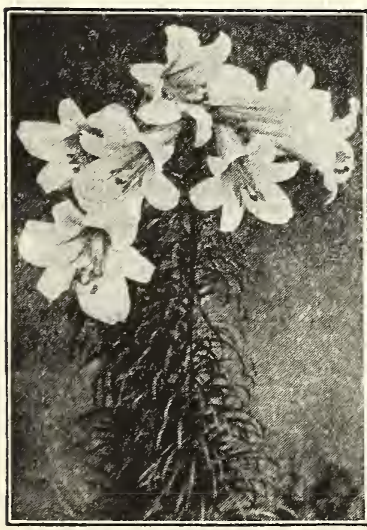

Regal Llly.
JAPANESE KUDZU VINE (Pueraria Thunbergiana). The fastest growing vine; when established making 12 to 14 inches a day. The rosy purple, pea-shaped flowers are borne in racemes in August. Large plants. Each, $40 \mathrm{c} ; 10$ for $\$ 3.00$.

TRUMPET VINE (Bignonia Radicans). A splendid, hardy climbing plant, with large, trumpet-shaped, scarlet flowers in August. Two-year-old: Each, 40c; per 10, \$3.50.

WISTERIA (Sinensis Alba). Of similar habit to Sinensis, but with pure white flowers. Each, $\$ 1.00$; 10 for $\$ 9.50$.

WISTERIA (Sinensis Alba), Of similar habit to Sinensis, but with pure white flowers. Each, 75c; 10 for $\$ 6.50$.

MADEIRA VINE. A beautiful, rapid growing vine, with dense foliage, white, fragrant flowers. A hardy plant if protected during the Winter. Strong tubers, 15c each; $\$ 1.50$ per doz., postpaid.

\section{HARDY LILIES}

LILY-OF-THE-VALLEY. This highly perfumed, delicate and refined looking lily should be given a pace in every garden. It plants. They show early in the Spring and are one of the first to bloom. It is very hardy and needs no attention in the Fall to carry them through the Winter. 6 pips for $40 \mathrm{c} ; 12$ for $70 \mathrm{c} ; 100$ for $\$ 6.00$.

TIGER LILY. Large flowers of orange color, spotted black, often 2 to 3 blooms to the stem; grows about 4 to 5 feet high and makes a dandy background. Plant about 1 foot apart. Each, 20c; dozen, \$2.00.

LEMON LILY. A pretty plant with long narrow leaves and flower stalks 2 to 3 feet high. These are crowned in June with delightfully fragrant beautiful lemon-colored flowers, 3 to 4 inches in diameter. A very popular variety; magnificent when planted in a large bed. Each, 15c: dozen, \$1.50.

LILIUM AURATUM (Gold-Banded Lily of Japan). Flowers 8 to 10 inches in diameter. Color white, thickly studded with chocolate crimson spots and a bright golden band through the center of each petal. Good sized bulbs, 40c each.

LILIUM SPECIOSUM RUBRUM. One of the best known. White, shaded and spotted with crimson; ery fragrant. Large size bulbs, 40c each.

LILIUM REGALE or MYRIOPHYLLUM. A new lily of rare beauty from northwestern China. The flowers are white, slightly suffused with pink, canary yellow at center, and very fragrant. Large bulbs. 50c each, postpaid. 


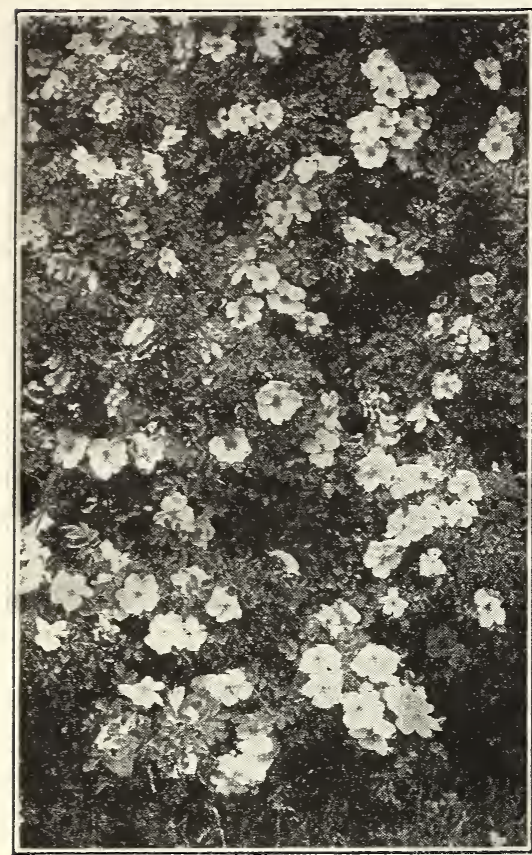

Rosa Hugonis.

PAUL'S SCARLET CLIMBER. The most brilliant rose known, because of its clear, vivid, shining scarlet; in large, semi-double flowers, which remain long in good condition on the plants. The flowers never turn blue. A wonderful rose for pillars and trellises, strong grower, heavy foliage, free from insects and grower, heavy folia
disease. Each, $75 \mathrm{c}$.

\section{Baby Ramblers}

A type of rose derived from the climbing Polyantha, dwarf in habit. It blooms the entire Summer until late in the Fall. They are very useful for bedding, edging borders, and cemetery purposes.

BABY CRIMSON RAMBLER. Brilliant ruby red. 65 c each.

BABY DORO'IHY. Pure pink. 65e each.

CATHERINE ZEIMET. White Baby Rambler. Snow white, double flowering. 65c each.

\section{ROSES-Continued}

HIS MAJESTY, H. P. Dark crimson shaded vermilion. Some class it as a Hybrid Tea. $60 \mathrm{c}$ each.

PAUL NEYRON, H. P. Deep rose, immense size, hardy, and vigorous. 60c each.

SENSATION. H. T. Enormous, scarlet-crimson blooms of deep form and substance: very sweetly scented. Plant is a strong and active grower. Each, 75c.

CONRAD F. MEYER, H. P. This rose is classified by some as the best Hybrid Perpetual ever grown, free bloomer, large, double, and cup-shaped, intense pink, very fragiant. 60c each.

F. J. GROOTENDORST

ROSA RUBIGINOSA

HANSA

PERSIAN YELLOW

See Page 61.

\section{Climbing Varieties}

CRIMSON RAMBLER. An old favorite, very hardy, of quick growth and very strong. Satisfaction sure. $60 \mathrm{c}$ each.

FLOWER OF FAIRFIELD. A counter part of Crimson Rambler, except that it shows everblooming tendencies. Each, 60c.

WHITE DOROTHY PERKINS. Same as the original Dorothy Perkins, except color is clear white. Fills long felt want for a hardy white climber. 60c each.

CLIMBING AMERICAN BEAUTY. Heavy strong grower, hardy everywhere; color, rich red fading to crimson, Very popular. 65c each.

CLIMBING GRUSS AN TEPLITZ. A perfect sheet of crimson when in bloom. It is the same as the bush Teplitz. 75c each.

DOROTHY PERKINS, PINK. Beautiful deep pink. Too well known for further description. One of our best climbers. 60c each.

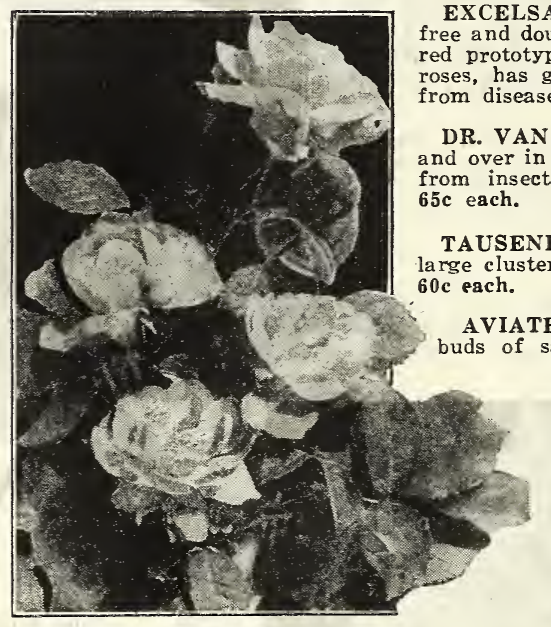

Paul's Scarlet Climber. $65 \mathrm{c}$ each.

radiant, blood red cluster rose, as EXCELSA. A radich it is the red prototype. Excelsa outgrows any of the regular roses, has good clean foliage and proves always free

FLEET. Flowers when open are 4 inches and over in diameter. It is absolutely hardy and free

TAUSENDSCHOEN. Soft pink, flowering freely in

AVIATEUR BLERIOT, H. W. Exquisite little affron-yellow, shaded apricot, opening to fragrance; blooms in clusters, thrifty growers, with a fine glossy foliage. Each, $65 \mathrm{c}$.

SHOWER OF GOLD, H. W. Deep golden vellow, very double, free and lasting; glossy bronze foliage. Each. 60c.

MARY WALLACE, H. W. Flowers are semi-double, well formed, very large, of a bright clear rose pink color, with salmon base. Each, 65c.

\section{PEONIES}

There is no other plant that will make such a magnificent display of rich colors and give as much satis faction in return for the trouble that you put in its cultivation. You should not be disappointed if the peonies do not quite come up to expectations the first year, for the second and succeeding years will make up for this if it should so happen.

The culture of the peonies is very easy and it/does not require any che earth must be spaded certain solitte mor deep. A little manure mixed in would not hurt. covering the crown only in shape, plant the roots from 2 to 3 feet apart, covering the crown only 1 , to 2 inches. Then give them plenty of water for b
best of the many varieties are those mentioned below.

FAUST. Shell pink. Midseason.

ROSEA ELEGANS. Soft pink. Midseason.

RUBRA TRIUMPHANS. Dark red. Early midseason.

EDULIS SUPERBA. Rose pink, very early.

GENERAL McMAHON. Bright crimson.

DUKE OF WELLINGTON. Ivory white with creamy white center.

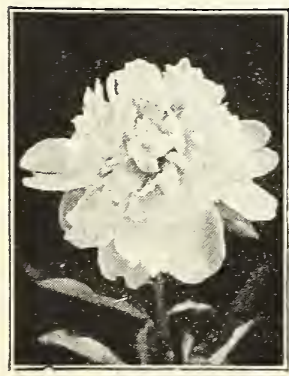

Edulis Superbe.
Ver'y large. Late.

OFFICINALIS RUBRA (Old Red). Flowers of a bright crimson, quite double, and globular. Very early and fine.

QUEEN VICTORIA. A good-sized flower; outside pure white, center creamy white; inner petals usually tipped carmine; early.

FESTIVA MAXIMA. Pure white center, prominently speckled with crimson; outer petals faint lilac white; extra large blooms, long stems : one of the finest and newest sorts; early.

Prices on above varieties, large healthy roots: Each, 50c; per ten, $\$ 4.50$, postpaid.

FELIX CROUSSE. Has large, globular flowers, solid and compactly built from edge to center, of a rich, brilliant, dazzling red. Exceptionally fiery, bright and effective. None better. Late midseason. $75 \mathrm{c}$ each, postpaid.

Unnamed varieties in pink, red, and white, 35c each; 3 for $\$ 1.00$, postpaid.

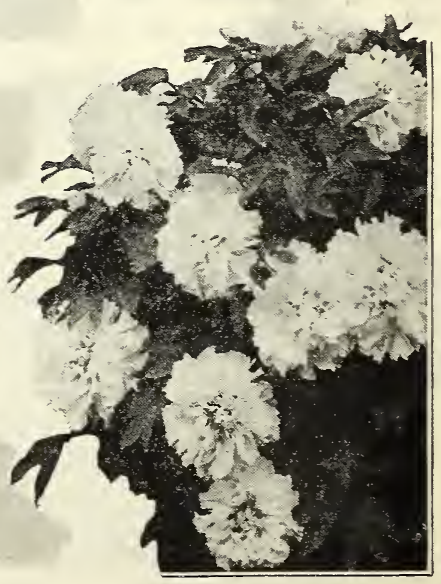

Festiva Maxime 



\section{CANNAS}

In preparing the ground for the canna, earth should be spaded at least 2 feet deep and plenty of stable manure mixed in. The from the surfice with little attention, the plants will bloom heavily.

HUNGARIA. The best pink canna, very compact, almost dwarf, and of a very luxuriant growth. Leaves bluish green, dwarf, and of a very luxuriant growth. Leaves bluish green, never burn; flowers very large with immense
purest La France pink. Each, 20c; doz., $\$ 2.00$.

KING HUMBERT. The greatest favorite today: scarlet flowers, bronze leaves. This remarkable Gold Medal canna has been the sensation of the last few years. Each, 15c doz., $\$ 1.50$.

FLORENCE VAUGHAN. Bright, rich golden yellow, spotted with red; 4 feet. Each, 15c; doz., \$1.50.

EUREKA. Large white blossoms on strong stems, an early sort, blooming through the entire Summer. Straight beds this sort are very popular; 4 feet. Each, 20c; doz., \$2.25.

ORANGE BEDDER. Green foliage. Color bright orange with just enough scarlet suffusion to intensify the dazzling mass of color. 4 feet. Each, 1 je; per doz., \$1.50.

MRS. ALFRED CONARD. Exquisite salmon-pink flowers of the largest size, produced in fine spikes well above the foliage. 4 feet. Each, $20 \mathrm{c}$; per doz., \$2.25.

THE PRESIDENT Flowers of immense size, with glowing scarlet color. Leaves rich green. 4 feet Each, 15c; per doz., $\$ 1.50$.

\section{CALADIUM - Elephant Ear}

A grand tropical looking plant, sometimes used for the center of the lawn when the southern or tropical appearance is wanted for the garden. No plant or flower could give the rame satisfaction as the caladium. The leaves oftentimes grow very large, measuring 3 feet long and $11 / 2$ feet wide,
attaining a height from 2 to 4 feet. Large selected bulbs. attaining a height from 2
Each, 20c; per doz., $\$ 2.25$.

\section{TUBEROSES}

Grown for their fragrant spikes of heavy waxen flowers. Below we are heaving waxen commonly grown, and both are old standards of grown, and

PEARL. Dwarf and double; white. and very fragrant.

VARIEGATED. Single, white; very early.

Price, either variety : Each, 10c; doz., $\$ 1.00$, postpaid.

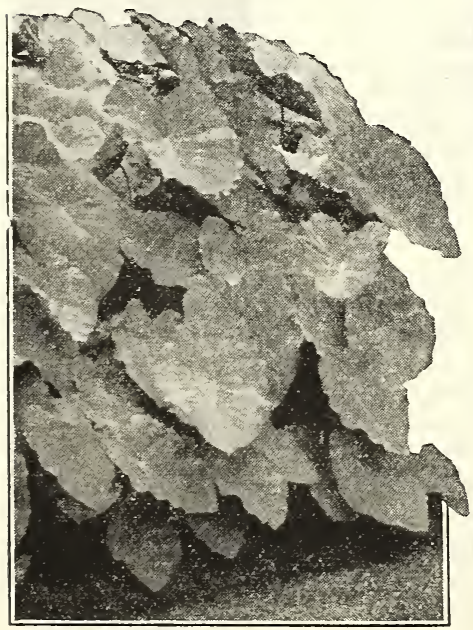

Caladium.

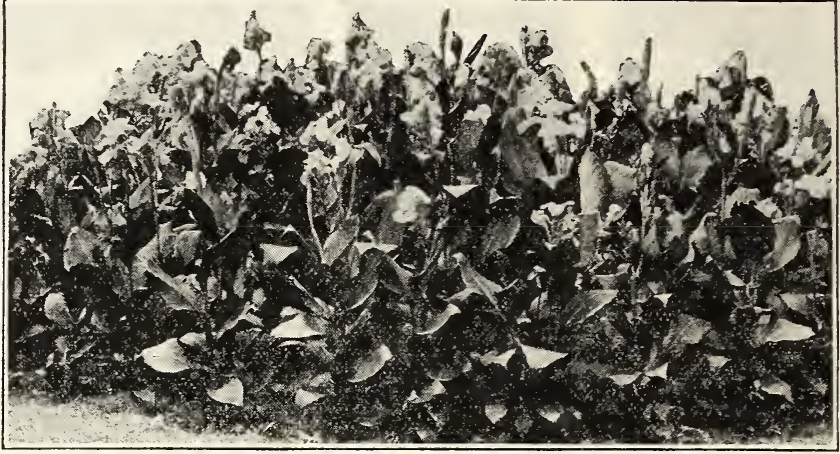

Cannas.

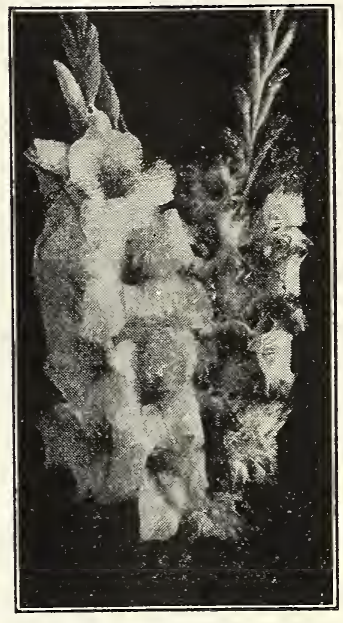

Gladiolus.

\section{GLADIOLI}

One of the most attractive of summer flowering bulbs is the gladiolus. A nice feature of this bulb is the culture; it does not require very much attention and only takes the usual amount of watering that is given any ordinary garden. In setting out pairly rich soil and spade deeply, then place lairly rich soil and spade deeply, then place gour bulb

WILBRINCK Fresh pink with creamy blotches, fine; extra early.

NIAGARA. Beautiful creamy yellow, primrose yellow throat.

PRINCE OF WALES, Delicate salmonrose of great value.

EARLY SUNRISE. Red, salmon-yellow throat, one of the earliest.

L'IMMACULEE. Pure white; medium size flowers.

LOUISE. Exquisite shade of bright lavender growing brighter toward center.

BARON HULOT. Deep rich purple.

E. J. SHAYLOR. A beautiful pure deep rose-pink.

FLORA. Fine golden yellow.

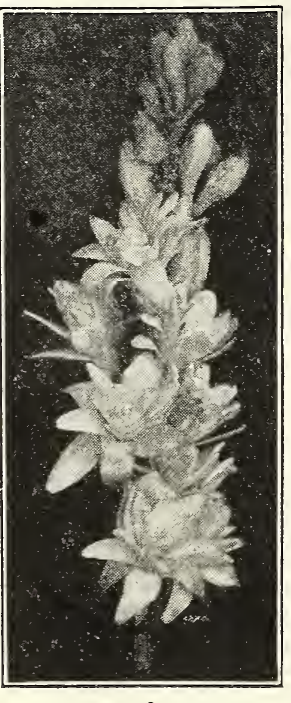

Tuberose.
ALICE TIPLADY. Bright orange, large open flowers, fine stems. HALLEY. Salmon-pink, very early.

MRS. FRANCIS KING. Vivid scarlet, long spikes.

MRS. FRANK PENDLETON. Bluish pink with brilliant carmine blotches.

Price, 10c each; any 3 for 25c; 6 for 45c; 75c per doz., postpaid.

GLADIOLI IN MIXTURE, Special. A choice collection of many colors in mixture, suitable for massing. $40 \mathrm{c}$ per doz.; $\$ 2.75$ per 100 .

OUR OWN MIXTURE. Consisting of all good bulbs of different shades and a very good mixture. 30c per doz.; $\$ 2.25$ per 100 .

\section{SUMMER BEDDING PLANTS}

Many annuals that are used for bedding have to be started in the house or under glass in order to be ready in time for outdoor planting, so we have arranged to grow these and you may secure the plants ready to bloom. Many people do not have the time and patience to grow and care for the young plants and prefer to set the plants out and have flowers with less labor and care. We are listing below some of the popular varieties, which were grown from our best seed and are true in form and color. Ready about May 1st. LOBELIAS. $\$ 1.00$ per doz.; 5 doz., \$4.50, postpaid.

CALENDULAS. $10 \mathrm{c}$ each; $\$ 1.00$ per doz., postpaid

CARNATION, Mixed Colors. 15c each; $\$ 1.50$ per doz., pastpaid. PETLNIAS, Assorted Colors. 10c each; $\$ 1.00$ per doz., postpaid. VERBFNAS, Mixed Colors. 10c each; $\$ 1.00$ per doz., postpaid. ZINNIAS, Mixed Colors, 10c each: $\$ 1.00$ per doz., postpaid.

SNAPDRAGONS, Assorted Colors. $10 \mathrm{c}$ each; $\$ 1.00$ per doz., postpaid.

MARIGOLD. $10 \mathrm{c}$ each ; $\$ 1.00$ per doz., postpaid.

\section{Pansy Plants}

The plants offered by us are grown from our Gold Seal mixture and produce larger flowers than any variety grown. But remember, the pansy cannot and will not live up to expectations unless placed on strong ground that has been heavily fertilized with well rotted barnyard manure, of water. 1 doz. plants ready to bloom, 60c; 5 doz., $\$ 2.50$, prepaid. Young plants, mixed colors, per $100, \$ 3.25$, not prepaid.

\section{Aster Plants}

CREGO GIANTS. The plants we offer are the best quality grown from the finest seed. We usually can offer them in separate colors-as crimson. pink, blue, lavender, purple or can furnish mixed colors. Price, postpaid, 60 c per doz.; 5 doz., \$2.35. Ready about May first. 


\section{Dahlias (Western Grown)}

To many people think of dahlias as the old-fashioned, either red, yellow or white stiff flowers, but, each year there has been a great improvement in dahlias, and the late creations are wonderful. Very few flowers can compare with them; such a wide range of color and shape, and the most pleasing thing about the dahlias is the never failing; wonderful results with ing thing about such little care.

The sorts we are offering are of the best quality, strong and true to name. In our lists we have included the late creations of such noted dahlia specialists as Judge Marean, Wilmore and Davis.

CULTURE. Pick a sunny spot if possible and spade well; do not use too much manure, for a small quantity goes far with the dahlia; then lay the root on its side about 4 inches from the surface. In covering, be sure to have the soil packed firmly about the tuber or roots; plant only when the soil is dry, then water sparingly.

Some flowers like dahlias, etc., wilt or fag soon after they are cut. Ordinary precaution is daily change of water. The best treatment for these is to pick them at the coolest hour, either late at night or early in the morning. Dip two or three inches of the stems in boiling water for two or three minutes and then place in cold water in a cold place. Do not hold flowers over the hot water, but dip the stems from the side, being careful not to heat the flowers. Another success is to dissolve an aspirin tablet in the vase

\section{Peony-Flowered Dahlias}

ISA. Fawn-pink, changing with age to amber-yellow. Each, 25c. JESSIE SEAL Clear old rose. Flowers very large. Each, 50c. LE GRANDE LILAS. Royal Purple. A wonderful dahlia. Each. 50. SWEETHEART BOUQUET. Salmon-rose, shaded fawn. Each, 50c. THE ORIOLE. Gorgeous combination of orange, red and yellow tipped white. Each, 50c.

LA GLORIETTA. Yellow base, shading to a beautiful rosy pink. Each, 50c.

QUEEN ESTHER. Beautiful deep red of enormous size. Each, 50c. ALBERT WARD. Deep purple, very attractive. Each, 50c.

NAIAD. A tinted cream-pink. Each, 50c.

\section{Show Dahlias}

A. D. LIVONI. Rich pink, finely formed. Each, 25c.

W. W. RAWSON. White overlaid with delicate lavender. Each, 25c. GLOIRE DE LYON. Largest white dahlia in cultivation. Each, 25c. BON TON. Ball shaped, deep garnet-red. Each, 25c.

HELEN HOLLIS. Orange-scarlet. Each, 25c.

MAUDE ADAMS. Pure white; overlaid clear pink. Each, 25c. MRS. C. D. ANDERSON. Rich clear purple, of large size. Each, 50c.

GOLDEN OPPORTUNITY. Rich buttercup yellow, shaded burnt orange. Each, 50c.

\section{Pompon Dahlias}

(These are the small variety-long lasting after cut). AMBER QUEEN. Rich clear amber. Each, 25c. JOE FETTE. A splendid new white. Each, 25c. NERISSA. Soft rosy pink. Each, $25 \mathrm{e}$.

VIVID. Bright red. Each, 25 e.

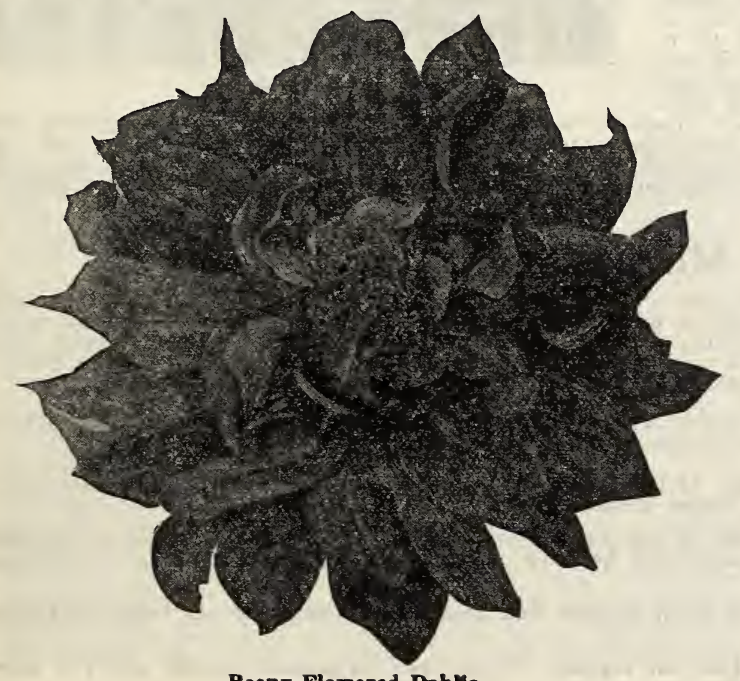

Pcony-Flowered Dahlle.

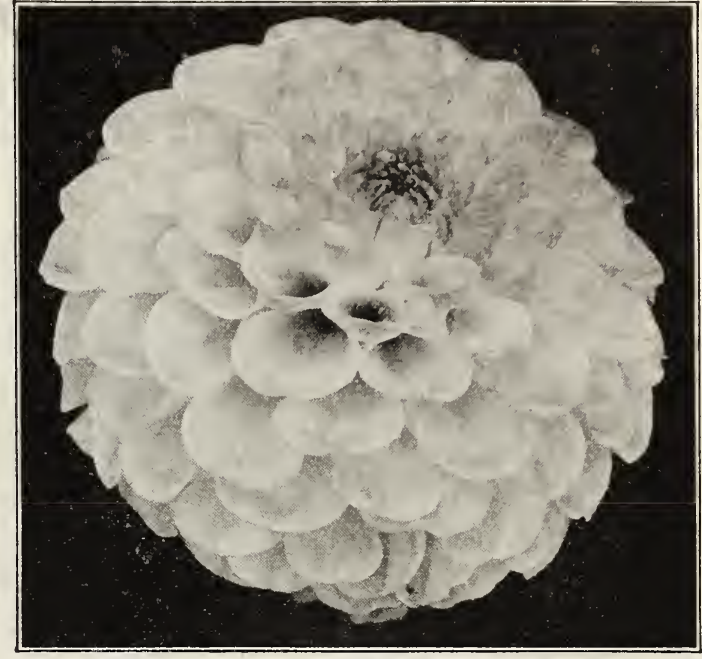

Show Dahlia.

\section{Decorative Dahlias}

AMUN RA. Copper and burnt orange. Each, $\$ 1.00$.

BERCH VAN HEEMSTEDE. Clear rich yellow. Each, $25 \mathrm{c}$.

CHICOTA. Golden yellow of large size. Each, 50c.

DELICE. Rosy pink of perfect form. Each, 25c.

JUDGE MAREAN (Judge Marean Creation). Salmon-pink, orange and gold. Each, $\$ 1.00$.

GRAND MANITOU. Purple streaked and mottled with crimson. Each, 25c.

MABEL THATCHER (Judge Marean Creation). Pale yellow. Each, 25c.

MAID OF KENT. Intense scarlet variegated with pure white. Each, 25c.

MILLIONAIRE. Lavender-pink. Each, 50c.

MRS. J. G. CASSATT. Mauve-pink, Each, 25c.

MRS. HARTONG. Light fawn suffused with pink. Each, 25c.

MRS. I. DE VER WARNER (Judge Marean Creation). Mauvepink. Each, 50c.

MRS. KARL SALBACH. Lavender-pink. Each, 50c.

PINK JACK ROSE. Lavender with a beautiful tint of blue.

Each, 25c.

QUEEN MARY. Shell pink. Each, 25c.

VENUS (Judge Marean Creation). Creamy white suffused with lavender. Each, 50c.

JERSEY'S BEAUTY. A most distinctive new dahlia of a rosepink color. Each, 75c.

GLORY OF NEW HAVEN. Large size flower of a very rare shade of soft mauve-pink. Each, 50c.

BEN WILSON. Orange and red, very large, free bloomer. Each, soe.

J. D. LONG. Color a blending of Autumn tints of salmon, pink, amber and bronze. Each, 50c.

EARL WILLIAMS. Brilliant crimson-scarlet color, tipped white; early free bloomer. Each, $\$ 1.00$.

ROSA NELL. A grand Decorative dahlia of a pure bright rose color. Each, 50c.

CHAMPAGNE. One of the largest dahlias grown. Color of dull golden champagne varying to chamois. Each, 50c.

OPHIR. Color rich old gold, shading to amber. Each, $\$ 1.00$.

\section{Cactus Dahlias}

COUNTESS OF LONSDALE. An exquisite shade of rich salmon, apricot at base of petals. Each, 25c.

F. W. FELLOWS. Orange and scarlet. Each, 50c.

GOLDEN WEST. Old gold. Each, 50c.

- KALIF. Nine inches in diameter; pure scarlet. Each, 50c. MRS. H. J. JONES. Bright red, tipped and edged with pure white. Each, 25c.

RHEINKOENIG. Pure snowy white. Each, 25c.

BRIDE'S BOUQUET. An ideal white Cactus, early, profuse bloomer. Each, 50c.

BETTY AUSTIN. Yellow, blending to rosy carmine. Each, 50c. ELSIE DREXLER. A deep velvety maroon of huge size. Each, 50c. ESTHER HOLMES. Mauve-pink, shading to lavender. Each, 25c. MARIPOSA. Beautiful pink center suffused with a faint violet. Each, $\$ 1.00$. 
In many sections of the West the rainfall is so slight and ground moisture so little that it is impossible to grow crops of the standard grains and grasses, and the acquirement of forage in these regions is a problem. On this page and those immediately following you can learn of many crops that have proven successful and have made farming profitable in the arid regions. But do not think that their gainful use ends with the dry land areas. They can also be used to good advantage where moisture is available. And of course their production then is nuch more prolific.

\section{SUDAN GRASS}

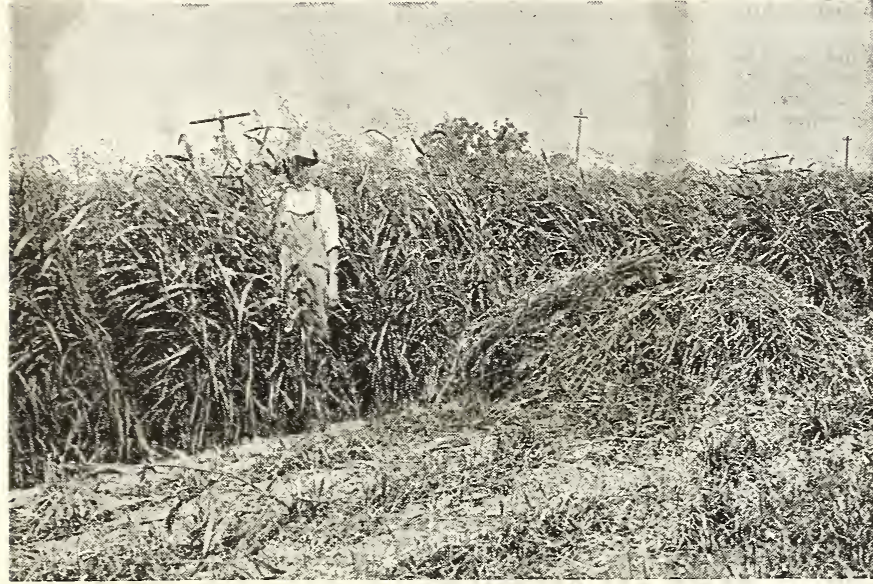

Sudan Grass is a grain sorghum and is non-saccharine. However the straw is very palatable and is eagerly consumed by all kinds of livestock. It is very nutritious and has proven to be a valuable feed for both milch cows and beef stock.

Although this wonderful forage crop is an annual and lacks an underground root system, yet it can be pastured to good advantage and under favorable conditions two cuttings of hay may be obtained. It does not make permanent pasture. It has been found profitable to sow peas or soja beans with Sudan Grass in sections where the rainfall is not too seant. Sudan Grass makes the heaviest yields on rich, loamy ground but has been grown successfully on every kind of soil from heavy clay to light sand. It is also looked upon with favor as a payin
a lack of moisture.

Plant when all danger of frost is over and the ground is thoroughly warm as the plant requires warmth and is not suited to altitudes above 7,000 feet. Sow ten to fifteen pounds per acre for hay and about five pounds for seed.

Cut for hay as soon as the grass is fully headed, with binder or mower as preferred. If planted in drills the crop can be conveniently handled with a corn binder. Northern grown seed is usually free from Johnson Grass. Prices, $1 \mathrm{lb}$., general quantity prices or submit list of your requirements for special quotations.

\section{Sudan Grass.}

\section{FETERITA}

Feterita is a native of Africa and is a leading variety in part of the Sudan region and has been grown in this country since 1906 . The heads are elongated and the seeds are bluish white and slightly larger than milo. The heads are always erect. Feterita appears to be able to withstand more drought than milo and sometimes produces a crop under conditions where milo fails. It is adapted to all purposes for which the kaffirs and milos are used, and is among the earliest of the non-saccharine sorghums. This might prove very valuable as a catch crop after some earlier spring crop had failed. The grain is soft and is quite valuable for poultry feed and will sell at milo prices. It makes a heavy growth, stools heavily, as many as six to eight shoots come from a single root. For hay, plant 20 to $30 \mathrm{lbs}$, to the acre $8 \mathrm{lbs}$, for seed. Prices, $1 \mathrm{lb}$ $15 \mathrm{c} ; 5$ lbs., $50 \mathrm{c} ; 25 \mathrm{lbs}$., $\$ 1.50$, not prepaid. Please write for general quantity prices or submit list of your requirements for special quotations.

\section{SUNFLOWERS}

Those who have grown sunflowers in the arid regions, both for seed and silage, are very enthusiastic over the results obtained.

Sunflower silage is very palatable. Cattle and sheep relish it, and stock will

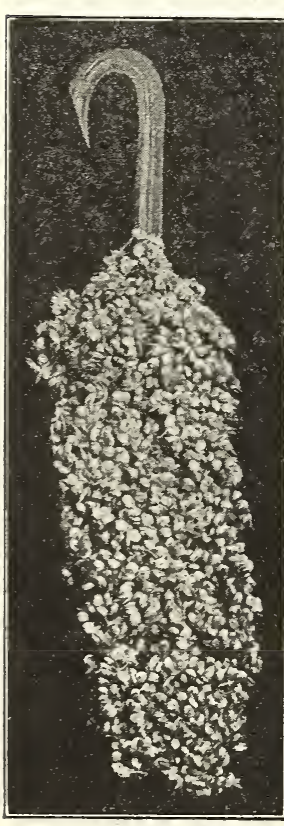

Dwarf Crookneck Milo [68] eat it as readily as they do corn silage. Sometimes in making the change from one to the other it takes a few days for stock to become accustomed to sunflower Silage. Its feeding value is high. It has been found to produce as much milk and butterfat as corn.

Sunflowers may be sown earlier than corn as light frost does not injure them after the plants are up. But on the other hand they grow so 15 th and satisfactory silage obtained but not mature seed when sown so late. They are often used to replant when corn has failed On dry land.

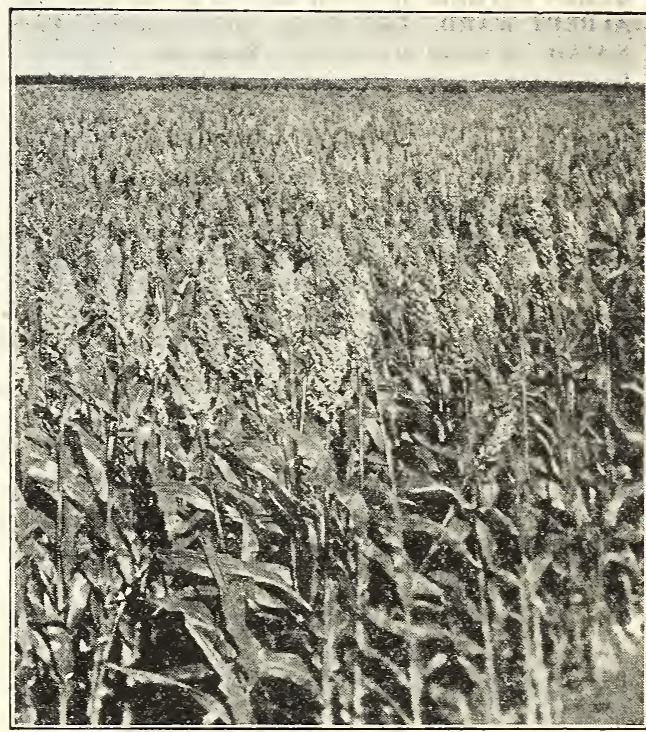

Feterita. to replant when corn has failed. On dry land, sunflowers have yielded from 3 to 8.5 tons of silage per acre and 37.6 tons per acre is one of the largest yields reported. Plant close in the drills four to five inches a part, rows thirty to forty-two inches apart and culti-
vate and handle similar to corn. Five to six pounds per acre is usual amount sown. Prices, 1 lb., $25 \mathrm{c} ; 5$ lbs., $\$ 1.00 ; 10$ lbs., $\$ 1.80$, not prepaid. Please write for general quantity prices or submit list of your requirements for special quotations.

\section{MILO MAIZE}

Milo Maize stalks contain practically no juice and are, therefore, not so palatable as many of the other grain sorghums, but the grain is very valuable for feeds, especially in prepared poultry feeds, and is very fattening for poultry or cattle. Sow about ten to fifteen days later than the average time for planting corn or as soon as the soil has warmed up to a considerable extent
seed, sow 5 to 6 lbs. to the aere and 20 to $30 \mathrm{lbs}$. for hay.

DWARF YELLOW MILO. Sometimes called in local sections, Double Dwarf, averages three feet high and has the greatest adaption and is the most valuable for the production of grain.

WHITE MILO MAIZE. This variety has white seeds as the name indicates. Does not yield as well as yellow maize and has no advantage over Dwarf Yellow Milo.

DWARF CROOKNECK MILO. The heads on this variety are pendant and the stalk arches to the heads like the curve on a walking cane Grows about five feet high and produces grain abundantly. It is sometimes called Single Dwarf.

STANDARU MILO. Grows to a height of seven or eight feet, producing an abundance of fodder that makes excellent silage.

Prices, 1 lb., 10c: 6 lbs., 50c; 25 lbs., \$1.50, not propaid. Please write for general quantity prices or submit list of your requirements for special quotations. 


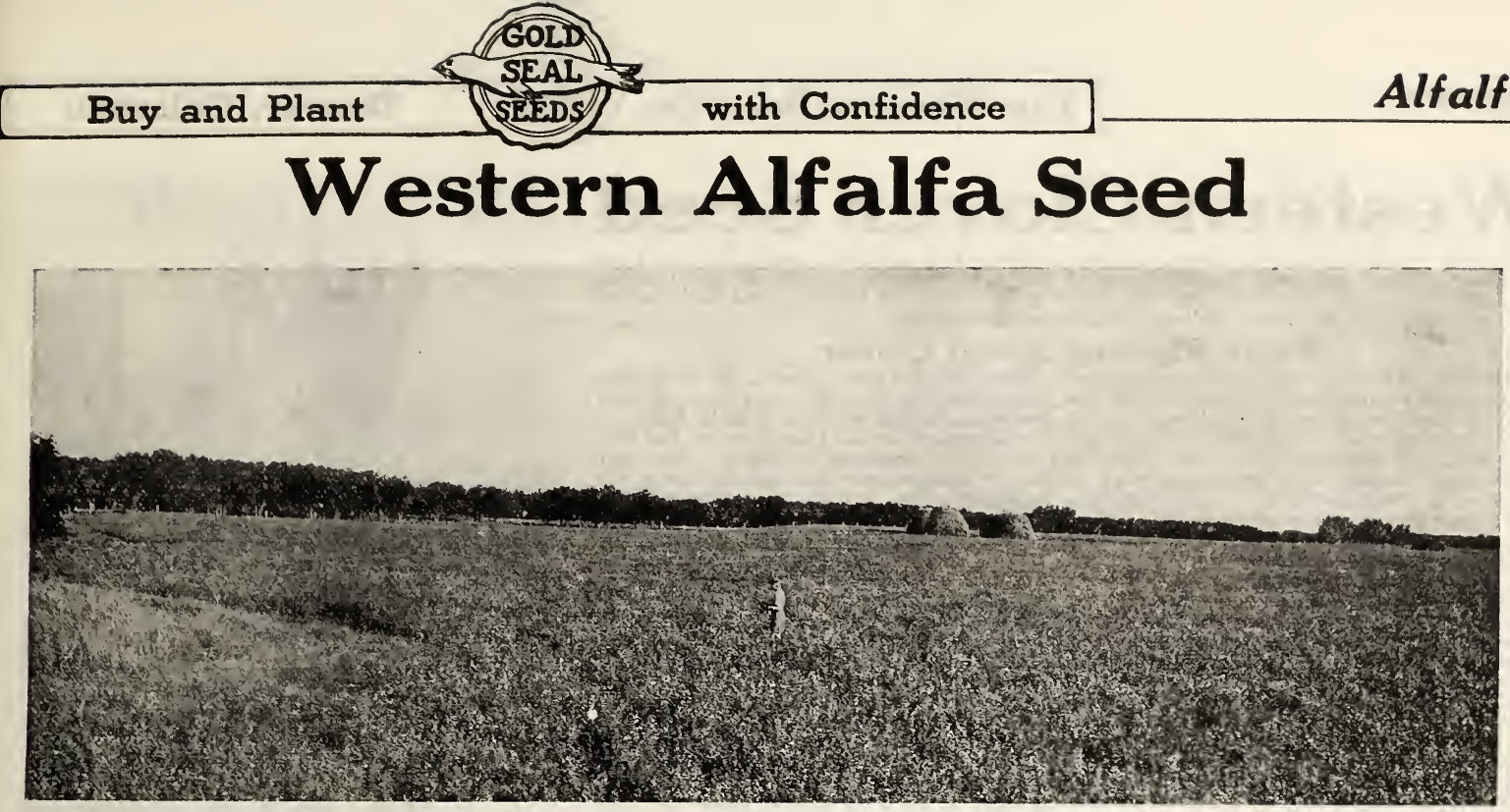

Alfalfa has done more to increase farm values in Colorado, Utah and Wyoming than all other crops combined. It will grow in any state of the Union, and is a valuable and profitable forage producing crop.

Alfalfa succeeds well in almost every situation, but the richer the soil, the better. After once a stand is obtained, it is very easily grown. In the West it is the main crop for hay, averaging three to five crops each season, which when fed to dairy cows, produces a fine flow of milk. Is equally good for sheep, and other stock. When it is ground into meal, it can be fed to hogs and chickens with favorable results. It is often sown with orchard grass and the mixture produces fine hay.

\section{NORTHERN GROWN ALFALFA SEED}

A great many planters lose their fields of alfalfa on account of winter-killing. This is sometimes due to the fact that thes have planted southern grown seed, produced from plants that never have withstood real cold weather.

To help to overcome this condition, we offer seed grown in northern latitudes for use in localities requiring hardy seed. And as a further precaution we recommend Grimm alfalfa seed for sowing in such localities. Our Bulletin, "Why Does Alfalfa Winter-Kill?" mailed free, on request.

\section{HIGH ALTITUDE ALFALFA}

This is a special strain of mountain grown seed produced in our high mountain valleys where alfalfa is put through the severest test of winter and the coldest weather. Most of the other varieties will winter-kill, but this grade usually survives and produces good yields of hay during the Summer.

The seed is usually very pure and of strong germination. This assures you a good stand the first year. As there is never a large quantity of seed grown in the mountains our supply is always short. We highly recommend this seed.

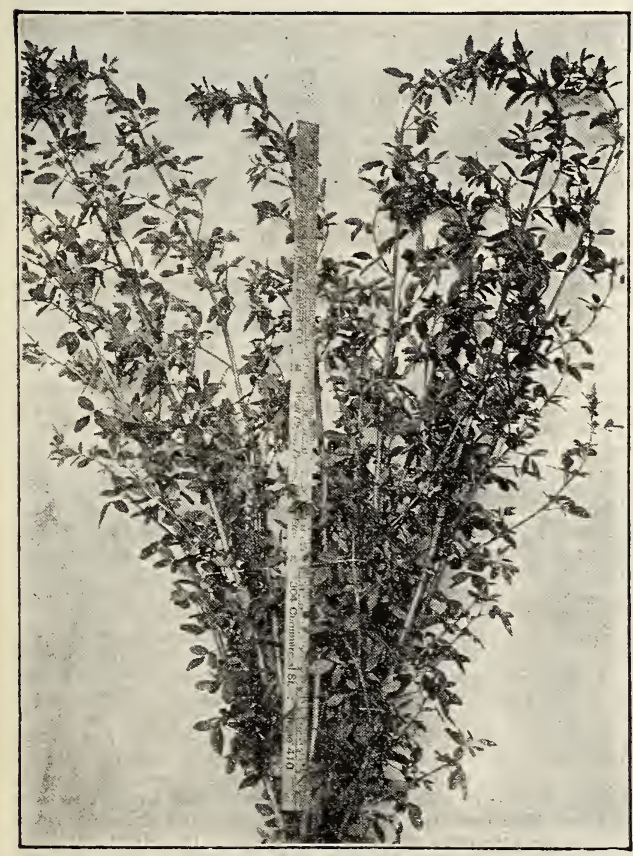

Alfalfe.
DRY LAND ALFALFA

Dry Land Alfalfa Seed is lands without irrigation with a limited amount of rainfall. This seed has more or less drought resisting ability.

The increase in our yearly sales on Dry Land Alfalfa stands as a convincing proof that this variety is giving the desired results. EXPLANATION OF GRADES

In addition to being able to supply alfalfa seed adapted to climatic and geographic conditions we can also furnish same in different grades.

Grade No. 1 -or Gold Seal, is selected and graded for perfect seed of perfect color and is of high purity and good germination. The standard pack of Gold Seal grade Alfalfa Seed will be in hundred pound, branded, sealed bags, on which a $U$. $S$. VerifiedOrigin Seed Certificate is securely fastened with our "Gold Seal" seal. This is really the best and cheapest grade to plant.

Grade No. 2-or Fancy, is a fancy looking grade but contains brown seeds that ripened early and acquired a brown appearance before the balance of the seeds matured. The purity and germination is good and good stands will be obtained.

Grade No. 3-or Choice. This is a grade of seed that cannot be worked up into either of the higher grades. It contains more inert matter and foreign seeds, and as a consequence must be sold at lower price. However, a larger quantity of seed per acre is required.

Grade No. 4-Special. In cleaning alfalla seed there is always an accumulation of light seeds and inert matter that contains considerable good seed that cannot be extracted. With a slight increase over the usual quantities sown, this grade of seed will produce good stands. It can be bought at a reasonable price, but as the stocks vary and are constantly changing, we prefer to send samples and prices. Grade No. 1, Gold Seal, with U. S. Verified-Origin Certificate. $\$ 1.50 \quad 10 \mathrm{Lb}$. $25 \mathrm{Lb}$. Grade No. 2, Fancy Seal, with U. S. Verified-Origin Certiflcate. $1.25 \quad 2.35 \quad 5.75$

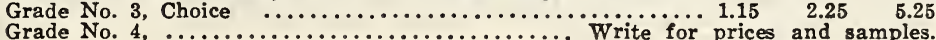

\section{Grimm Alfalfa}

To the casual observer Grimm Alfalfa does not differ materially from the common strains, but close examination will reveal a rreat diversity of forms, upright mon strains, but close examination will reveal a great diversity of forms, upright and prostrate individual plants often occurring side by side. In 1905 the United States Department of Agriculture began experimenting with Grimms and in practically every case it has proven itself the equal to any, if not superior to all, in hardiness. The Grimm variety is distinguishable from the Common by its variegated blooms-a large percentage are purple, but there are a few that are greenish, smoky or blackish and occasionally a yellow flower will be found. The taproots show a tendency to branch and the crowns to be low set and spreading; characters which are undoubtedly of great importance in rendering Grimms resistant to cold

CERTIFIED GRIMM ALFALFA. Certified Grimm Alfalfa is sealed and tagged by state officials in $25-1 \mathrm{lb}$., $50-1 \mathrm{~b}$. and $100-\mathrm{lb}$. sealed bags. We cannot break the original containers and furnish Certified Grimm Seed under official seal Prices, not prepaid: 25 lbs. \$11.00; 50 lbs., \$21.50. Please write for general quantity prices or submit list of your requirements for special quotations.

AFFIDAVIT GRIMM. This is seed of Grimm origin and the plants show true Grimm characteristics but growers have failed to obtain inspection or to maintain proper records, so we can only furnish copy of grower's affidavit from the original affidavit on file in our office. Prices, not prepaid: $1 \mathrm{lb}$., $40 \mathrm{c} ; 5 \mathrm{lbs} ., \$ 1.80$; $10 \mathrm{lbs}$. \$3.50. Please write for general guantity prices or submit list of your requirements for special quotations.

Under supervision of the U. S. Department of Agriculture, we are authorized to isser supervision of the . S. Department of Agriculture, we are authorize to issue verified-origin seed certificates for alfalfa,

Alfalfa, clovers, soy beans, vetches, peas, beans, cowpeas, peanuts and other legumes should always be inoculated with McQueen's Dust-Kote Inoculator. The lack of necessary bacteria in the soil is often the cause of a poor legume cropa weak start-or a total failure. See page 85 . 


\section{Western Clover Seed}

Clovers, being leguminous crops, are soil builders and are very useful for the farm or ranch. They are used for mixtures of hay and pasture as well as sown alone. The different kinds grown in the West are fully described below. The best variety for your land can be readily chosen from these descriptions.

\section{White Blossom Sweet Clover}

Melilotus Alba or White Blossom Sweet Clover, or Bokhara Clover, as it is also called, is a hardy biennial plant, erect and branching in growth. It starts up very early in the Spring and in its second year it reaches a height of from 5 to 12 feet. It seems to grow in all climates and with little regard to the character of the soil. It is found growing in gravel pits, heavy clay soils and sometimes in almost pure sand. And when planted in ground containing alkali, for one or two seasons, it leaves the soil fertile. Not particular as to moisture, it stands more dry weather than alfalfa. like these plants, has the faculty of extracting nitrogen from the air and storing it up in the roots, thus fertilizing the soil for the use of succeeding crops.

It is a valuable forage crop; while some animals refuse it at first because of its peculiar taste and odor, they soon learn to like it and thrive on it. In food value it does not differ greatly from alfalfa. For hay it should be cut early and is handled in much the same way as alfalfa. A second cutting can usually be secured 40 to 60 days later, if not pastured. It is also used to some extent as an ensilage crop, put into the silo and fed successfully in this way.

After the corn has been laid by scatter sweet clover between the rows, covering it light with a drag such as the branch of a tree or a small bush. If conditions are right, the increased yield of corn, the Fall pasturage from the clover, the green manure to be plowed under in the Spring as food for the succeeding crop, will make the planting well worth while. Try it and you will be a sweet clover fan.

Prices, Hulled-1 lb., 20c; 5 lbs., 75c. Scarified-1 lb., $25 \mathrm{c}$; 5 lbs., $\$ 1.00$; 10 lbs. $\$ 1.50$, not postpaid. If wanted by parcel post add postage. Please write for general $\$ 1.50$, not postpaid. If wanted by parcel post add postage. Please write
quantity prices or submit list of your requirements for special quotations.

\section{Yellow Blossom Sweet Clover}

Melilotus Officinalis or Yellow Blossom Sweet Clover is similar to the White Blossom, and will grow on almost any kind of soil. It is more spreading in habit and does not grow as tall and large as the White Blossom, and for that reason makes a finer and more tender hay. Cattle prefer it to any other sweet clover. It is ten days earlier than White Blossom and on that account is given preference for planting in high altitudes, and is highly recommended for pastures and used in pasture mixtures. See Morton's Pasture Mixture, page 74. Do not confuse this biennial variety with Annual Yellow Blossom Sweet Clover. Prices, Hulled-1 lb., 20c; $5 \mathrm{lbs}$., 75c. Scarified-1 lb., $25 \mathrm{c} ; 5 \mathrm{lbs} ., \$ 1.00 ; 10 \mathrm{lbs} ., \$ 1.50$, not postpaid. If wanted by parcel post add postage. Please write for general quantity prices or submit list of your requirements for special quotations.

\section{Hubam Sweet Clover}

Hubam Clover is an annual plant with a white blossom. It is a wonderful fertilizer, adding nitrogen and humus to the soil and making a splendid Summer and Fali pasture. It is a rich hay crop and a wonderful honey producing plant. It grows 3 to feet high in 4 to 7 months after planting and seems to thrive well in every state. Sow 12 pounds per acre broadcast or 3 pounds in cultivated rows in the Spring. Prices,

\section{Grundy County Sweet Clover}

Is a biennial plant with white blossoms. It matures earlier than the ordinary White Sweet Clover and is dwarf and consequently makes fine hay. It is a good soil improver and stands the Winter well. Prices, $1 \mathrm{lb}$., $20 \mathrm{c} ; 5$ lbs., $75 \mathrm{c}$. If wanted by parcel post, add postage. Please write for prices on large amounts.

\section{Medium Red Clover}

Red Clover (Trifolium pratense) can be seeded any time from April to October, at the rate of $\mathbf{1 5}$ pounds to the acre, and makes a fine early spring pasture. Red Clover is a legume and is therefore a fine soil builder. The hay is fine for all kinds of stock. It can be planted with numerous grasses when hay or pasture is desired, for hay produced from Red Clover is very nutritious and fattening. The seed we are offering is very pure and free from all injurious weed seed. Prices, $1 \mathrm{lb}$., $35 \mathrm{c} ; 10 \mathrm{lbs}$., $\$ 3.00$, not postrequirements for special quotations.

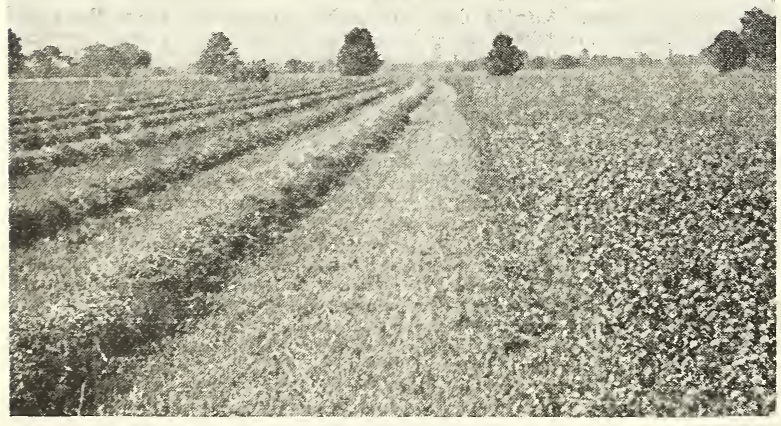

Medium Red Clover.

\section{SOIL FERTILITY}

Inoculate your Alfalfa, Sweet Clover, Soy Beans, Vetch, Peas, Beans, Clovers and all other legumes (pod-bearing plants), with McQueen's Dust-Kote Legume Inoculator.

Inoculation hastens maturity, increases the crop, improves its quality, enriches the soil and saves fertilizer bills.

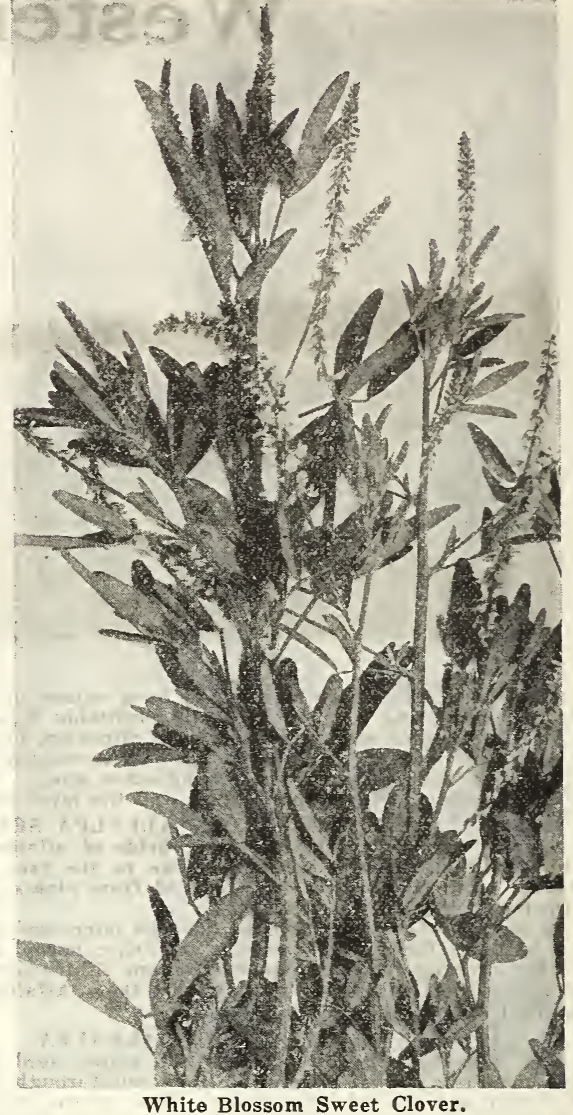

\section{White Dutch Clover (Trifolium RePEns)}

OR LAWN CLOVER

A small, close growing useful clover of unusually dwarf habit, used extensively in the making of lawns. In fact, no lawn seems just right unless it has a sprinkling of this little white-blossomed clover mixed through it. It is a rapid grower of spreading habit, and can be cut very close to the ground without injury to the plant, which after cutting, will start making another growth at once.

When used in a mixture for lawns, use two parts of White Clover to ten parts of Kentucky Blue Grass. For pastures, use 10 to 12 pounds of White Clover mixed with 20 to 25 pounds of grass seed to the acre. This will give an excellent stand that will form a heavy sod that is almost impossible to stamp out. Prices, $1 \mathrm{lb}$., $55 \mathrm{c}$; 5 lbs., $\$ 2.50 ; 10$ lbs., $\$ 5.00$, postpaid. Please write for general quantity prices or submit list of your requirements for special quotations.

\section{Alsike Clover (TRIFOLIUM HYBRIDUM)}

This is undoubtedly the best high altitude clover for hay and is planted extensively throughout the Rocky Mountain regions where alfalfa often winter-kills. Although not a very heavy yielder, it bears a very thick growth of leaves and blossoms on thin stems, bears a very thick growth of leaves and blossoms on thin stems, making it a valuable forage crop. When grown alone will make fair stand the first year, sut the second and succeeding years the best results are obtained. Nany of our stockmen who raise hay have the finest and most nutritious hay ever fed in the Rockies. The seed we offer is hardy. It was grown in the high altitudes of our mountains where the seasons are short. This makes it pure because the foul seeds that you so often find mixed with the alsike cannot grow in these altitudes. One ton of alsike contains more protein than one ton of alfalfa. Prices, $1 \mathrm{lb}$., $35 \mathrm{c} ; 10 \mathrm{lbs}$., $\$ 3.00 ; 25 \mathrm{lbs}$., $\$ 7.25$, not postpaid. Please write for general quantity prices or submit list of your requirements for special quotations.

\section{Mammoth Red Clover}

Especially adapted for poor ground and will produce more hay or forage than any clover in the same length of time, but only affords one cutting. It is used mostly for building up run down farms. 8 to 10 pounds of seed to the acre will give you an excellent stand.

This is also a pasture clover and is especially valuable on light, sandy soil, supplying excellent grazing, makes good hay if cut when young, but if left too long the stems become thick and woody. Mammoth Red Clover is very valuable for fertilizing purposes, for it restores fertility to depleted soils. The foliage, flower and stem are
darker in color than Medium Red Clover. For pasture this clover is hard to beat, being a vigorous grower. Prices, 1 lb., 40c; $10 \mathrm{lbs}$. $\$ 3.50$, not postpaid. Please write for general quantity prices or submit list of your requirements for special quotations. 


\section{Western Grasses for Pasture and Hay}

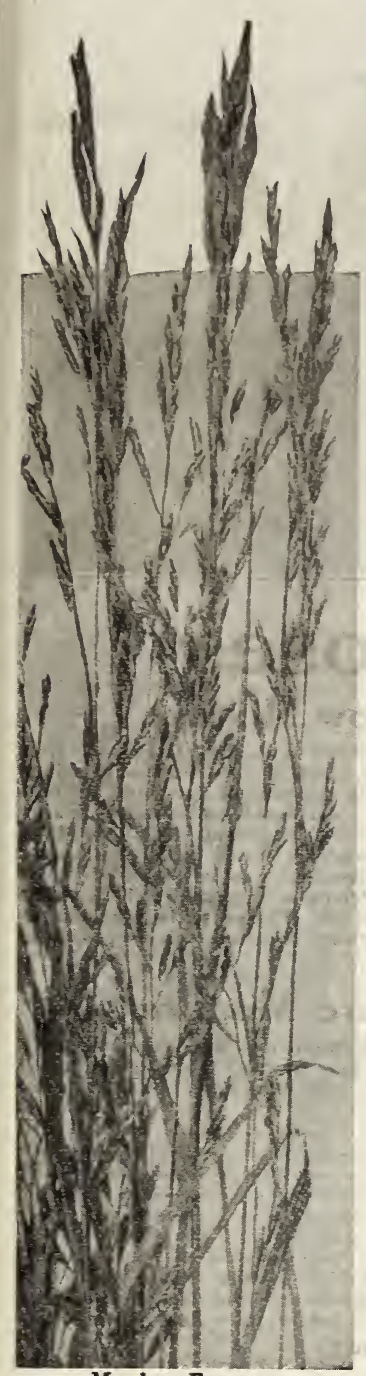

\section{Brome Grass}

BROMUS INERMIS or HUNGARIAN BROME GRASS. Stands excessive drought and extreme cold weather without injury. It is a vigorous, hardy perennial with strong creeping root stalks; smooth, upright, leafy stems, one to four feet high, and loose, open seed heads, four to eight inches long. In a few years it forms very tough sod soon crowding out other grasses, clovers, and weeds. Its remarkable drought resisting qualities have proved it to be the most valuable grass for dry regions where other grasses would hardly exist. It is thoroughly permanent and grows with wonderful rapidity, producing heavy crops and hardly exist. It is thoroughly permanent and grows with wonderful rapidity, producing heavy crops and
luxuriant pasture. Its value to the farmers of dry regions cannot be over-estimated. All kinds of stock eat it with relish and chemical analysis shows that it is richer in flesh-forming ingredients than timothy. It starts to grow very early in the Spring, before any of the grasses upon native prairies show any signs of life, and remains green far into December. Our seed is northern grown and should not winter-kill in Colorado. Without doubt it is the grass for dry regions of the West; also flourishes on wet lands Prices, not prepaid: $1 \mathrm{lb}$., $35 \mathrm{c} ; 5 \mathrm{lbs}$., $\$ 1.65 ; 10 \mathrm{lbs}$., $\$ 3.00$. Please write for general quantity prices or submit list of your requirements for special quotations.

\section{Meadow Fescue or English Blue Grass}

FESTUCA PRATENSIS. One of the grasses most used in permanent or temporary meadows for mowing or for pasture. It succeeds best in cold, moist, light soils, in well-drained meadows and in low valleys rich in organic matter. It should not be grown at all on warm dry land. It does not reach its full development till the second or third year. After being mown, it grows again very quickly. The forage, either green or dried, is very nourishing and much relished by cattle, especially when cut young.

It will produce a green lawn where Kentucky blue grass would fail, and many prefer it to any other grass for this purpose, but it should be sown very thick, 2 lbs, to 100 square feet will make fine turf. Meadow Fescue is also known as Festuca Elatior, Herbi Prateii, or Tasmanian blue grass. Price, not prepaid. 1 lb., 30c; 5 lbs., $\$ 1.25$. Please write for general cuantity prices or submit list of your requirements for special quotations.

\section{Timothy (PHLEUM PRATENSE)}

The most popular of all grasses that are used for hay purposes. It requires less in time and expense to secure 8 crop of timothy than almost anything else you can plant. It is easy to sow; does not require much seed per acre starts growing quickly; easy to harvest, and above eversthing else, it is easy

to sell timothy hay. can be irrigated, or that is naturally damp. And when planted on clay or heavy soil an extra heavy yield may be expected.

Timothy hay has a high feeding value when it is cut early while still in bloom, or shortly afterward. The average yield of timothy is two or three tons $\$ 3.00$. Please write for general quantity prices or submit list of your requirements for special quotations.

\section{Red Top (agrostis alba)}

A valuable grass for moist soils and low land. It is a good permanent grass standing our elimate as well as any other, and consequently well suited for pastures, in which it should be fed close, for if allowed to grow up to seed the cattle refuse it. On rich, moist soil it will grow 2 feet and on poor soil about half that height. Red Top grass grows rapidly and often thrives where Kentucky blue grass fails. so it is used straight for lawns and in lawn grass mixtures. Prices, not prepaid: 1 lb., 40c; 5 lbs., $\$ 1.75$. Please write for general quantity prices or submit list of your requirements for special quotations.

\section{Orchard Grass (DACTYLIS GLOMERATa)}

Orchard orass is a valuable grass for pasture or hay land on account of it earliness. It is very well adapted for permanent pasture. When grown for hay, more than one crop can be obtained in one season, but when only one crop is cut the undergrowth is very heavy and gives splendid and rich pasture until late in the Fall. It will stand drought and is hardy. It grows in tufts, and is therefore best sown with red clover or alfalfa. It is well suited for shady places, such as orchards and groves. Grows in all kinds of land, but 5 lbs., $\$ 1.45 ; 10$ lbs., $\$ 2.50 ; 25$ lbs., $\$ 5.50$. Please write for general quantity prices or submit list of your requirements for special quotations.

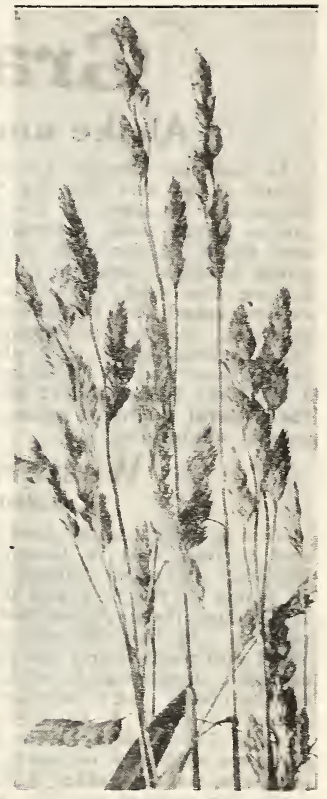

Orchard Grass,

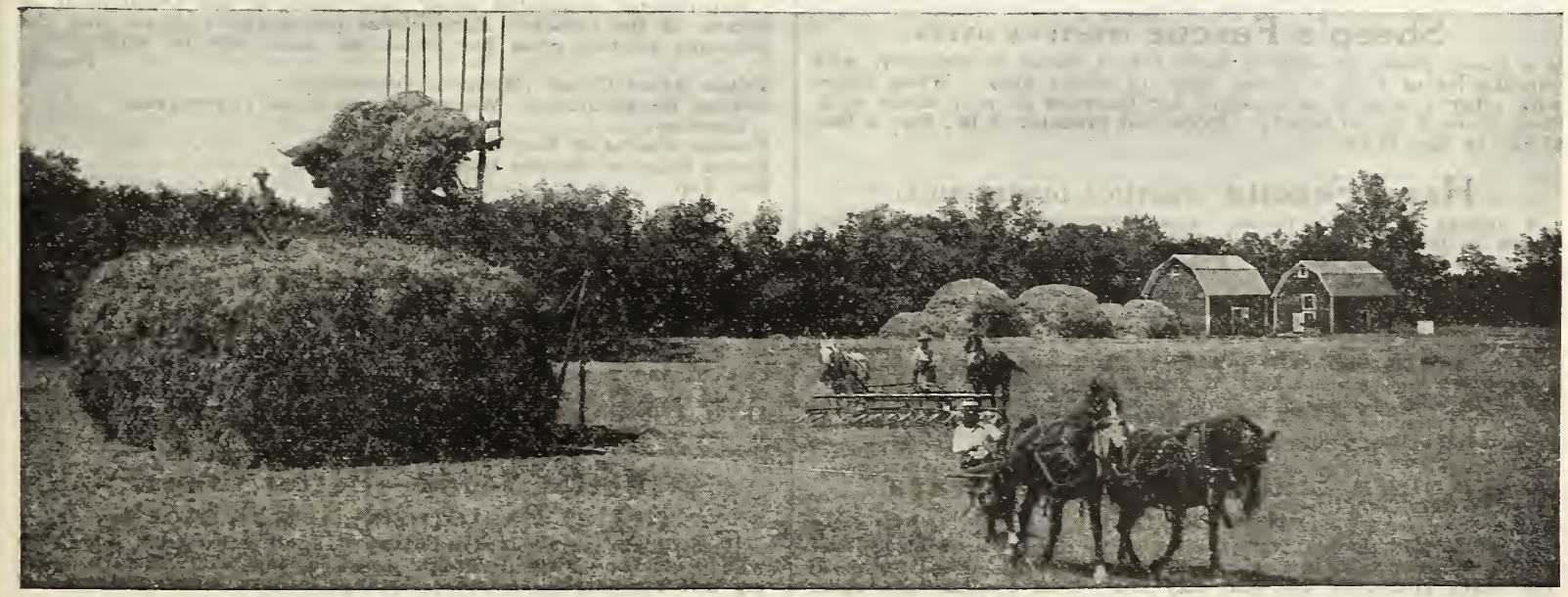




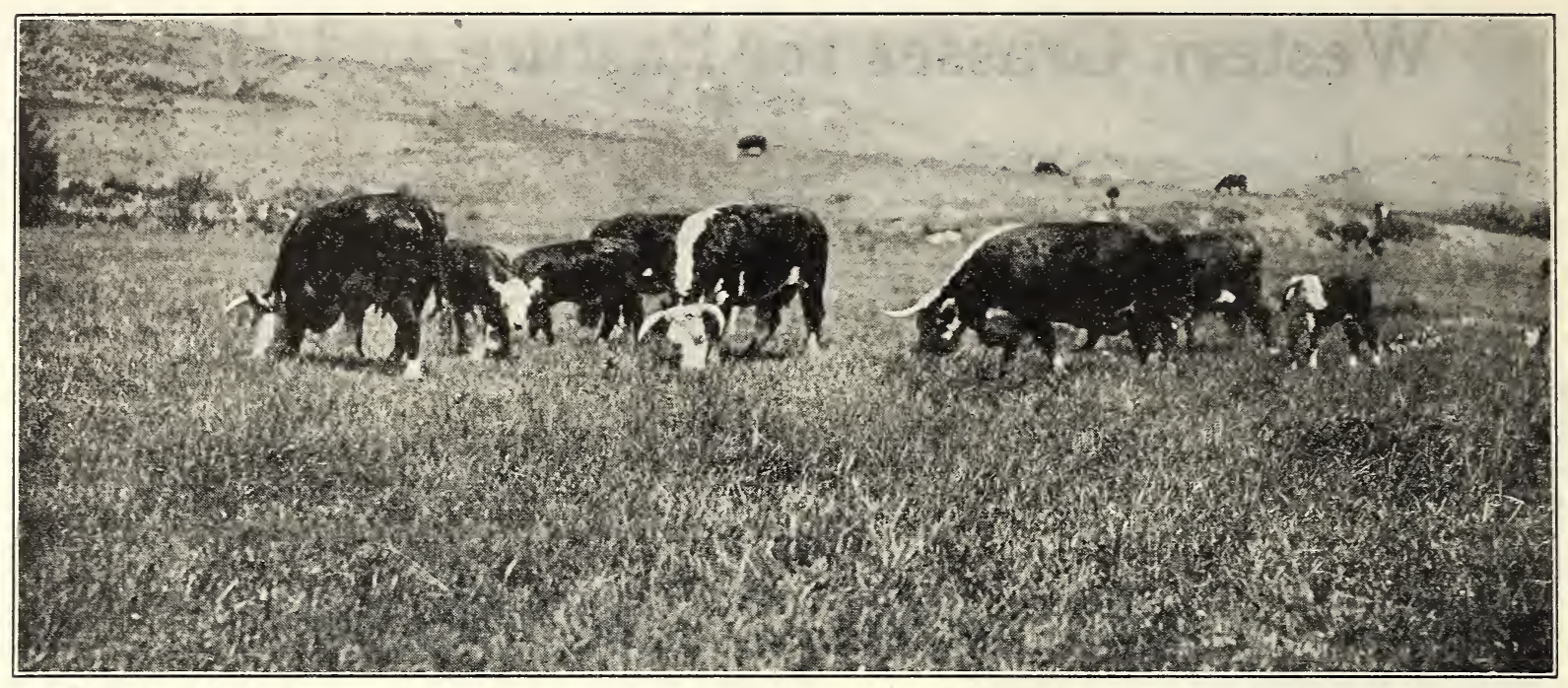

\section{Grasses for Many Purposes}

\section{Alsike and Timothy Mixed}

In cleaning timothy for seed there is always a certain amount of mixed clover and timothy that is taken from the timothy, as it is impossible to senarate the two by machinery. So we are offering you a mixed seed, consisting of about 25 per cent of alsike clover and about 75 per cent of fancy timothy seed. To those who are going to plant timothy and clover together, money can be saved by buying this seed, for it is much cheaper already mixed. An excellent stand can be secured by planting 12 to 15 pounds of this mixture. Alsike and timothy hay is much richer in feeding value than timothy alone, for alsike is one of the best clovers for hay, being finer and more leafy than other sorts. Prices, not prepaid: 1 lb., 30c; 5 lbs., \$1.25; 10 lbs., \$2.25; 25 lbs., \$5.00. Please write for general quantity prices or submit list of your requirements for special quotations.

\section{Western Wheat Grass \\ AGROPYRUM TENERUM}

This is the valuable plant that grows wild over our western country and thrives well in Colorado, Wyoming. New Mexico, and North Dakota. It is the famous bunch grass of the Canadian Northwest. It is one of the best and is the surest hay grass for these sections. It produces large quantities of hay and makes excellent permanent pasture. It, like the wild buffalo grass, is the natural grass of the West and particularly adapted to our prairie soils. It also does well on land impregnated with alkali. It withstands drought and the cold winters. As a mixture it does fine with Brome grass. Fifteen pounds of seed is usually sown to the acre, and if planted with pounds of seed is usually sown to the acre, and if planted with Brome, $71 / 2$ pounds to the acre. The seed being quite heavy, may be sown with any ordinary grain seeder. Plant 1 to 3 inches deep.
Prices, not prepaid: $1 \mathrm{lb}$., $20 \mathrm{c} ; 5$ lbs., $90 \mathrm{c} ; 10$ lbs., $\$ 1.50$. Please write for general quantity prices or submit list of your requirements for special quotations.

\section{Sheep's Fescue (Festuca ovina)}

is a bunch grass, growing in tufts 3 to 6 inches in diameter, with wirelike leaves 2 to 4 inches long, of bluish gray. When mixed with other grasses it is excellent for fairways on poor sandy soils. Wown alone it is too bunchy. Price, not prepaid: $1 \mathrm{lb}$., 50c; 5 lbs., $\$ 2.40 ; 10$ lbs., $\$ 4.50$

Hard Fescue (Festuca duriuscula) A variety of sheep's fescue. Leaves broader, wirelike, not flat. Grows in bunches if sown alone. Will thrive on thin, sandy soil and is used for the "rough." Price, not prepaid: 1 lb., 50c: 5 lbs., $\$ 2.40 ; 10$ lbs., $\$ 4.50$.

\section{Chewings Fescue (FEstuca Chewings)}

This grass spreads out, forming a plant one foot in diameter, making a solid compact turf of a dark ceedingly well on soils of a sandy nature and is now recognized as one of the leading grasses for putting greens. Prices, not prepaid: one of the leading grasses for putting
I lb., 60c; 5 lbs., $\$ 2.90 ; 10$ lbs., $\$ 5.50$.

\section{Rough Stalked Meadow Grass (POA TRIVIALIS)}

A spreading, thickly matted grass with narrow leaf blades, flat and dark green in color. Forms a fine turf and is suited for moist and shady situations and stiff clay soil. Used for fairways under and shady situations and stiff elay $80 i l$.
trees. Price, not prepaid: 1 lb., $75 c ; 5$ lbs., $\$ 3.50$.

\section{Mountain Meadow Mixture}

Will do well in high altitudes, making a heavy, thick sod that withstands the severe colds. Can be sown in the Fall or Spring. using about 25 pounds to the acre. On account of its rapid growth satisfaction is attained the first year. An excellent sort for mountain meadows and high lands. If allowed to grow, it will produce a fine crop of clean, nutritious, well-proportioned hay, which may be cut and cured for winter use and the field can be pastured without injury to the next year's crop. Prices, not prepaid: $1 \mathrm{lb} ., 40 \mathrm{c}$; 5 lbs., $\$ 1.75$; 10 lbs., $\$ 3.25$; 25 lbs., $\$ 7.50$. Please $w$ rite for general quantity prices or submit list of your requirements for special quotations.

\section{Morton's Pasture Mixture}

The Colorado Agricultural College recommends the following ratio for a well-balanced permanent pasture mixture and gives these quantities as the proper amounts to sow per acre, reseeding the clover every two years:

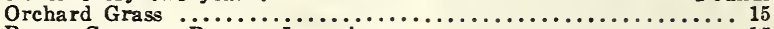

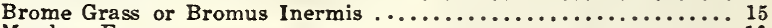

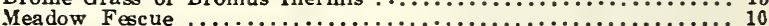

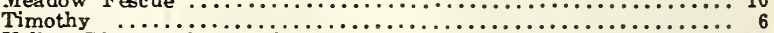

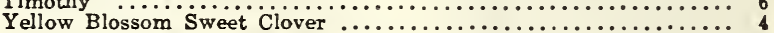

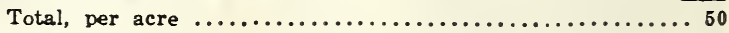
These seeds should not be mixed before sowing. Sow the grass seeds separately from the timothy and clover. Write for prices on quantity desired.

\section{Mixture for Alkaline Lands}

Experiments conducted under supervision of the Department of Botany of the Colorado Agricultural College have shown that the following mixture gives fine results on lands infested with alkali: Yellow Sweet Clover (Melilotus Officinalis) ...............6.6 Slender Wheat Grass or Western Wheat Grass (Agropyrum

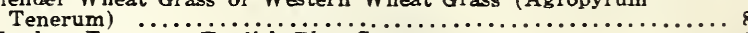

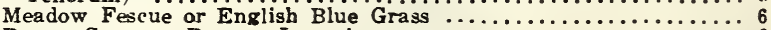

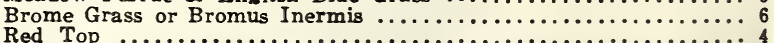

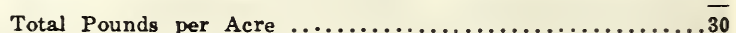
This mixture has done well under very severe conditions.

Coos Bent Grass (Agrostis Maritima)

This is also known as Seaside Bent or Oregon Bent. It is a true creeping bent, a native of our western coastal regions and is used on the putting greens of golf courses. It is a rapid grower, heals quickly, and is capable of resisting severe drought, coming quickly to life as soon as moisture is supplied. Prices, not prepaid: 1 lb., submit list of your requirements for special quotations.

\section{Better Seeds-Better Crops.}

Better Pastures-Better Stock.

If cattle are eating quietly instead of hunting for feed, their gain will be quicker with more profit. Good pastures will also turn dairy. ing into a profitable business. Arrange to have better pastures and better toek. 


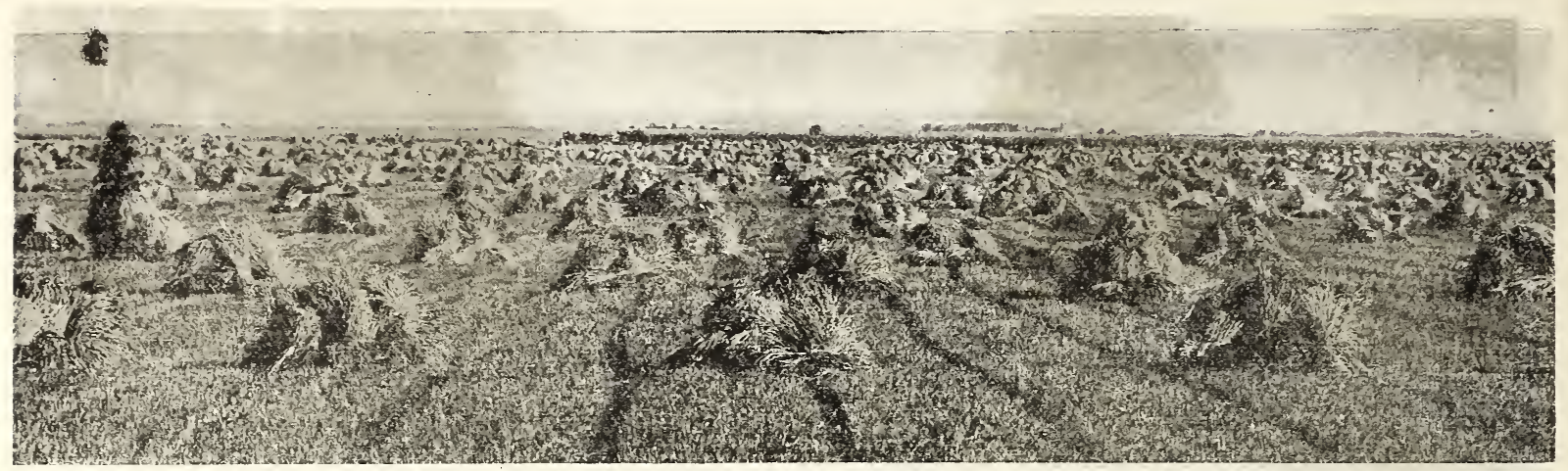

\section{Seed Wheat}

\section{Marquis Wheat}

Is a very early, beardless, hard, red, spring wheat, very productive. It has higher milling and baking qualities than most of the varieties of spring wheat known today, and will almost always grade No. 1 . Besides being about 10 days earlier than most spring wheats it generally outyields them and has been known to produce $\mathbf{4 5}$ to 60 bushels per acre.

As it is short, stiff strawed, it is not likely to lodge and stands up well under irrigated conditions in Colorado. The grain is plump 5 lbs., 50c: 10 lbs., $80 \mathrm{c}$. Please write for general quantity prices or submit list of your requirements for special quotations.

\section{Defiance Wheat}

The old standard variety of spring wheat planted extensively in the Middle West as the main crop wheat. The Defiance is a perfect wheat with extraordinarily heavy yielding qualities. The kernel is plump, and if harvested before being allowed to over-ripen, it never shells out of the hull. The stalk is medium in height and makes excellent straw. It is not termed a dry land wheat, but oftentimes good yields are reported from dry lands. Defiance is considered one of the best milling varieties grown. It is beardless. Prices, not prepaid: 1 lb., 15c; 5 lbs., 50c; 10 lbs., 80c. Please write for general quantity prices or submit list of your requirements for special quantity pric

\section{Macaroni or Durum Wheat}

This wheat grows very strong and with surprising rapidity, so rapidly as to get ahead of the weeds, and not only are the growing qualities in its favor but it is also a heavy yielder. Macaroni wheat produces as good a yield of grain to the acre as most any other variety. It does not shell or bleach and is hail proof to a certain extent, owing to the tightness of the hull. It is not a milling wheat, but is grown only where other varieties it is not a milling wheat, or when feed is wanted. wheat very seldom fails to produce grain even on our dry lands where it has won the favor of the dry farmers as a sure wheat crop. It has a very hard kernel and is known as a glue wheat, and is bearded. Prices, not prepaid: 1 lb., 15c; 5 lbs., 50c; 10 lbs., 80c. Please write for general quantity prices or submit list of your requirements for special quotations.

\section{Turkey Red Winter Wheat}

A standard red bearded wheat with very strong straw. It is early ripening before rust and insects appear. Average yield is 30 to 40 bushels to the acre. The kernels are large, red, and hard, and it is in good demand by millers and most always grades No. 1. Prices will be supplied upon request throughout the Summer. Prices, not prepaid: $1 \mathrm{lb} ., 15 \mathrm{c}$; 5 lbs., 50c; 10 lbs., 80c. Please write for general quantity prices or submit list of your requirements for special quotations. We can also supply Beardless Turkey Red, Winter
qual quotations. We can also supply Beardless
Wheat at same price as the bearded variety.

\section{TREATMENT FOR BUNT OR STINKING SMUT IN WHEAT}

Dust seed grain with copper carbonate two to four ounces to the bushel. Mix in a barrel mixer so that all grains are covema with the dust. Treatment can be made at any time and grai- $n$ be stored without injury.

\section{TREATMENT FOR LOOSE SMUT AND COVERED SMUT} IN OATS

Add one pint formaldehyde to forty gallons of water and sprinkle on forty bushels of grain. Cover with sacks or canvas for two to four hours.

\section{Seed Oats}

We will have Registered Colorado Grown Bliss Side Oats, Colorado No. 37 Oats, and Victory Oats this season for early orders and early shipment. There will be a Blue Tag issued by the Extension Department of the Colorado Agricultural College sealed on every bag.

\section{Bliss Side Oats}

A selection from the white Russian side oats which has been and still is in some sections a favorite with many. Mr. E. R. Bliss, of Weld County, striving to get oats that were pure, made the field selection from heads showing desirable characteristics and has carefully developed from this.

Experience shows that the type of head which this oat has with the grain all drooping from one side of the stem, is not damaged so badly by grasshoppers and light hail as the branched type of head.

ady by grasshoppers and light hail as the branched type of head. feeding is desired, this is one of the best that can be planted for feeding is desired, this is one of the best that can be planted for
that purpose. The Bliss side oats ripen uniformly, the fields present very attractive appearance, and the yield of grain is usually very satisfactory. Owing to the small size of the grain, many are led o believe it has not the feed value of larger oats, but it is true that the percentage of meat to the hull is about the same as in the larger types and the thin hull permits it to be more easily digested.

The side oat has proven to be a very satisfactory oat for mountain districts.

Prices,-not prepaid: 1 lb., 15c; 5 lbs., 50c; 10 lbs., 80c; 25 lbs. \$1.50. Please write for general quantity prices or submit list of your requirements for special quotations.

\section{Colorado No. 37 Oats}

This variety was produced by selection. The original mother plant was selected from a field of oats in the San Luis Valley, but further purification and selection has been made by the agronomy department at the agricultural college. It is an open panicled white oat and belongs to the Swedish group. The hull is medium thick, but the straw is stiff and it is well adapted for irrigated conditions and cooler dry land conditions. It yields well and has led other varieties over a period of years. It yields well and has led other varie-

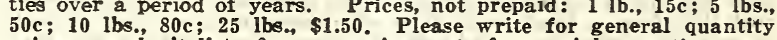
prices or submit list of your requirements for special quotations.

\section{Victory Oats}

Ever since the war many different oats have been sold under the name of Victory. Some of these were good and some not so good but it was apparent that no one knew which was the true Victory as introduced into Canada from Sweden. The oats now registered under the name Victory in Weld County are all from the same importation. These oats were secured as second generation seed from the Canadian government breeding plots in Edmonton, Alberta, the Canadian g

This Victory is a Swedish type oats with large-sized plump grain, and thin hull. The plants are hardy and yield well under irrigation. Genuine Victory oats are good size, plump, solid grain and are especially desirable because of the thin hull and plump kernel; over 90 per cent of the grain is meat. This is very essential to good oats. More grains set on the head than varieties that have a big, thick hull. Victory oats are the hardiest oats grown; they are early and make enormous yields.

One field of registered oats in Weld County yielded 102 bushels per acre and the average of four growers was 88 bushels. Prices, not prepaid: $\mathbf{1}$ lb., $\mathbf{1 5 c ; 5}$ lbs., 50c; 10 lbs. $\$ 1.50$. Please write for not prepaid: $1 \mathrm{lb}, 1^{15 c ;} 5 \mathrm{lbs} ., 50 \mathrm{c} ; 10 \mathrm{lbs} ., \$ 1.50$. Please write for
general quantity prices or submit list of your requirements for special quotations.

\section{Swedish Select Oats}

It is an abundant yielder of heavy fine grains. It is vigorous and produces fine straw of excellent quality. The seed we offer is especially adapted to our western country, being earlier and more drought resistant than the oats offered from other sections. As it produces excellent straw it is grown extensively in our mountains and cut just before the grain ripens and used for hay. Prices, not prepaid: 1 lb., 15c; 5 lbs., 50c; 10 lbs., 80c; 25 lbs, $\$ 1.50$. 


\section{Western Seed Grains}

\section{Trebi Barley}

Imported by the U. S. Department of Agriculture in 1905 from Asiatic Turkey where it had been undex irrigation for many years. Trebi is a six-rowed, pure line variety with heads similar to those of Coast barley. Under government tests in California and Minnesota it did not show up well, but when taken to Idaho in 1913, under western irrigated conditions, it took front rank from the first. The Aberdeen. Idaho, experiment station made pure line selection that greatly improved its yield and quality and distributed it to our western farmers.

It was introduced into northeast Colorado from Idaho about 1920, and has led other varieties in both yield and quality of grain. It has been in Weld County only three years and is replacing all other varieties by and quality of grain. It has been in Weld County only three years and is replacing all other variet.

The kernels are large and bluish in color and the awns, while long, break off more easily than those of the Coast variety and cause it to thresh out much cleaner. Lamb and cattle feeders in Weld County much prefer it to other varieties for feeding. We unhesitatingly recommend this barley for irrigated farms.

As a dry land crop we are not prepared to make any recommendations. It has been tested for a number of years at several dry land experiment stations, and in years with a fair amount of rainfall it has proven to be one of the best. However, under actual dry farming conditions in Logan County, it is gaining popularity rapidly.

Prices, $1 \mathrm{lb} ., 15 \mathrm{c} ; 5 \mathrm{lbs} ., 50 \mathrm{c} ; 10 \mathrm{lbs} ., 80 \mathrm{c}$. Please write for general quantity prices or submit list of your requirements for special quotations.

\section{Bald or Hulless Barley}

This is one of the many forage plants that have met with success in our western country and is one of the best crops for green feed. It is very early and grows rapidly, which makes it a favorite where green feed is wanted. It can be used as cured hay, but should be cut or harvested when it is in the milk stage. If allowed to mature will make an excellent grain, which resembles wheat. It is not a milling variety but when ground is an excellent feed for stock, which do well on it. It resists drought remarkably well, It will make a large crop of grain in dry seasons, even when wheat will fail. Yields well on poor lands It will make a large crop of grain in dry seasons, even when wheat will fail. Yield
and better on good land. It has no beard and shells off its hulls the same as wheat.

Prices, 1 lb. 15c; 5 lbs., 50c; 10 lbs., 80 c. Please write for general quantity prices or submit list of your requirements for special quotations.

\section{Colsess Barley}

Colsess barley is a six-rowed hooded variety of hybrid origin, produced and developed by the Agronomy Department of the Colorado Agricultural College. It is the result of a cross between Coast and Success. Heads are more compact and darker than Success but resembling Coast in color. It has been developed to supply a demand for a high yielding barley that is free from beards that many stock feeders object to because of trouble caused by the stiff awns in the threshed grain and straw.

From the tests conducted by the Colorado Experiment Station it has outyielded all other very favorably with the highest yielding bearded varieties. It has proven itself to be especially has proven itself to be especially gions and high altitudes, as it is one of the earliest high-yielding varieties.

The straw is stiff, causing it to stand up well under irrigation and it shatters less than Coast or Success. As a beardless variety, under irrigated conditions, it can be depended upon to give greater yields than any other beardless variety yet tried.

Prices, 1 lb., $15 \mathrm{c}$ : 5 lbs. 50c; 10 lbs. 80c. Please write for 10 lbs, 80c. Please write for general quantity prices or submit
list of your requirements for special quotations.

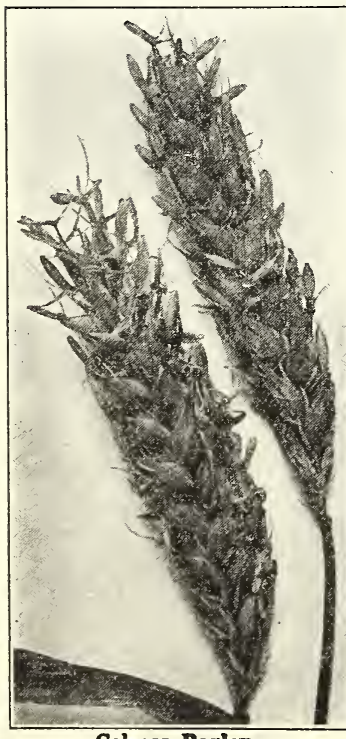

Colsess Barley.

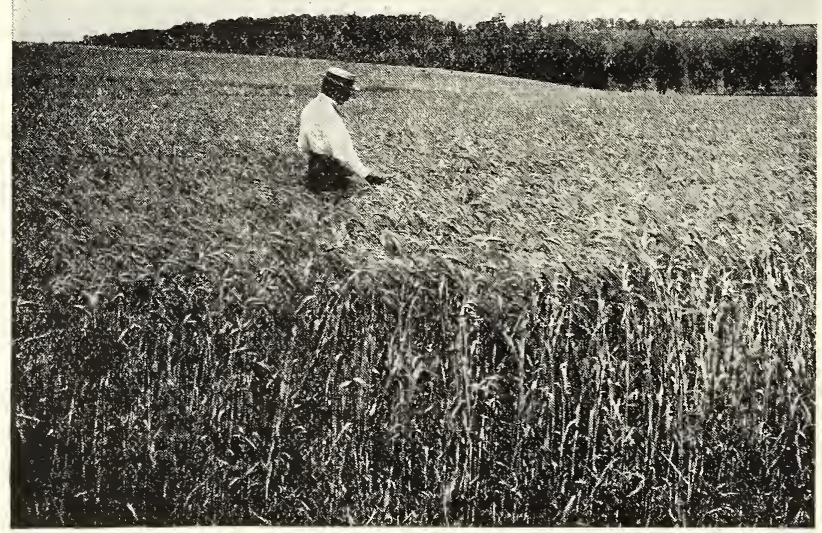

\section{Oderbrucker Barley (Six Row)}

Oderbrucker is a tall, heavy-strawed barley that stands up well and gracefully. The heads are usually large and long and are completely filled out with very plump grains that are brighter and whiter than any other barley. Our seed of Oderbrucker barley was grown from seed furnished by a careful and successful grower who took great have graded it so that it is the best grade of barley ever offered by us.

Prices, $1 \mathrm{lb}$. 15c; $5 \mathrm{lbs}$. 50c: $10 \mathrm{lbs} .80 \mathrm{c}$. Please write for general quantity prices or submit list of your requirements for special quotations.

\section{Spring Rye}

As a cleaning crop for the purpose of eradicating wild oats and other foul seeds, Spring rye can not be beaten. It is an excellent soiler and can be produced on poor worn out land under dry conditions where wheat would be a comparative failure. Sow produced on poor, worn out land under dry conditions whed or blown wou or where a fall crop has not bow Spring rye on ground where winter grain has been kiled or

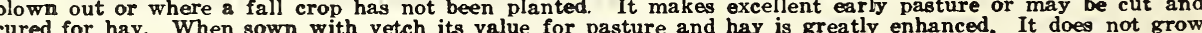
cas tol winter rye and the straw is fis value for pasture and hay is greatly enhanced. It does not grow for the grain. Prices, $1 \mathrm{lb} .15 \mathrm{c} ; 5 \mathrm{lbs} .50 \mathrm{c} ; 10 \mathrm{lbs} ., 80 \mathrm{c}$. Please write for general quantity prices or submit list of your requirements for special quotations.

\section{Rosen Winter Rye}

Selected in 1909 at Michigan Agricultural College from Russian rye it was sparingly tried out in Colorado and has made good here, increasing the rye yields to a remarkable degree, even to the extent of excluding the common variety of fall rye. Rosen rye stools well and for this reason is recommended by the Agronomy Department of the Colorado Agricultural College for sowing in the Spring for use as a temporary pasture. Department of the colora Agr Its superiority is shown mixed easily and it is highly important to get pure seed. Spring and summer sowing of Rosen rye makes prices or submit list of your requirements for special quotations. 


\section{Field Corn

\section{Western Seed Corn}

\section{Minnesota No. 13}

Minnesota No. 13 is the most popular Yellow Dent Corn in Colorado and other western States. It matures in 90 to 100 days. This makes it a very desirable corn for sections where early frosts are common. The ears set about four feet from the ground, average 7 to 10 inches long, 6 to 8 inches in circumference and carry 12 to 16 rows of kernels. The kernels are wedge shaped and of a bright, rich yellow color; smooth and packed closely from butt to tip on a small reddish cob. Throughout the West it is used extensively as a husking crop. The stalks grow six to eight feet and being thick, tall and leafy they make excellent, nutritious fodder. Plant Minnesota 13 Corn for grain, fodder, and silage.

Prices, not prepaid: 1 lb., 15c; 5 lbs., 50c; 10 lbs., 80c; 25 lbs., \$1.50. Please write for general quantity prices or submit list of your requirements for special quotations.

For early orders we expect to have a good stock of dry land Registered Minnesota No. 13 Corn, Colorado grown.

\section{White Australian}

White Australian is a hard flint corn well adapted for cool climates and short seasons. It withstands drought well and matures in ninety days. The ears are of medium size, tapering, grow about 12 inches long and average 12 to 16 rows of kernels. The kernels are white, smooth, somew hat shallow, rounded and very flinty. The stalks attain a height of from 5 to 8 feet, producing one to two long ears to the stalk, that set about 3 feet from the grouna. White Australian is a sure cropper and good yielder in almost all sections of Colorado but is not a favorite where whole grain feeding is desired

Prices, not prepaid: 1 lb., 15c; 5 lbs., 50c; 101 bs., 80c; 25 lbs., $\$ 1.50$. Please write for general quantity prices or submit list of your requirements for special quotations.

\section{Colorado Yellow Dent}

Colorado Yellow Dent is by no means a fixed type of corn. Different lots of seed will develop different growths, different stalks, different ears and different kernels. The grains are usually mixed and sometimes resemble Minnesota 13 and sometimes more like Pride of the North. This is due to the fact that growers have not selected the seed by ear selection and have made no attempt to keep their strains true to the original types. However, this corn is thoroughly acclimated, matures early, yields well, withstands drought very satisfactorily and is a prime favorite in the dry land sections.

Prices, not prepaid: $1 \mathrm{lb}$., 15c; 5 lbs., 50c; $10 \mathrm{lbs} ., 80 \mathrm{c}$; $25 \mathrm{lbs} ., \$ 1.50$. Please write for general quantity prices or submit list of your requirements for special quotations.

\section{Swadley}

Swadley is an early dent corn maturing in 90 days. It has great ability to withstand heat and drought and is a prime favorite in many sections of Colorado. It ranks equal to Australian Flint as a sure cropper under adverse conditions and is planted in preference to Australian for whole grain feeding. The ears are large and set low on the stalk, average 7 to 9 inches long and carry 12 to 16 rows of grain. The kernels are large, broad and thin, of a light yellow color merging into white on the cap. The cob is white and of medium size. The stalks attain a height of 5 to 7 feet and are rather large and sparsely leaved. Swadley is distinctly a Colorado product and we recommend it very highly.

Prices, not prepaid: $1 \mathrm{lb}$., 15c; 5 lbs., 50c; $10 \mathrm{lbs} ., 80 \mathrm{c} ; 25 \mathrm{lbs} ., \$ 1.50$. Please write for general quantity prices or submit list of your requirements for special quotations.

SEED CORN TREATMENT WITH SEMESAN JR.

Usually results in these benefits: Protects seed against rotting, makes early planting safer, increases germination, controls seedling blight, invigorates seedling growth, produces sturdier plants, reduces root and stalk rots, decreases down corn, improves ear and fodder quality and increases down corn,
crop yields.

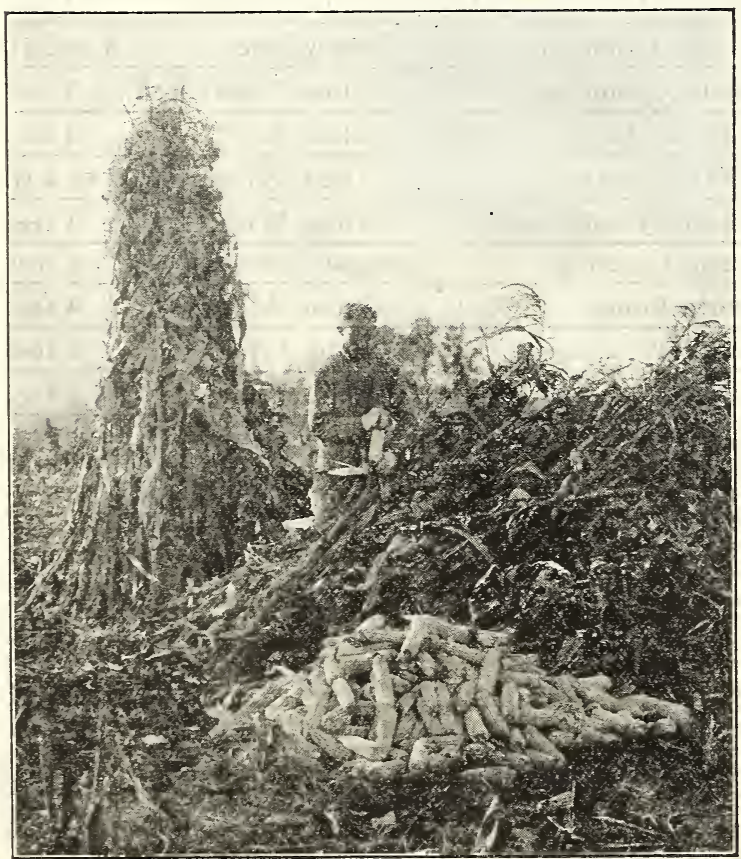

Minnezota No. 13.

\section{Western White Dent}

Western White Dent is a short season corn requiring about 90 days to mature. This makes it very desirable where a soft white corn is sought. The stalks average six to eight feet tall with ears 10 to 14 inches long and with 16 to 20 rows of nice, white kernels. The ears are large and the cob small and white. They set high making this variety suitable for husking. It is also a very efficient corn for silage and fodder.

Prices, not prepaid: $1 \mathrm{lb}, 15 \mathrm{c} ; 5 \mathrm{lbs}, 50 \mathrm{c} ; 10 \mathrm{lbs}$., $80 \mathrm{c} ; 25 \mathrm{lbs} ., \$ 1.50$. Please write for general quantity prices or submit list of your requiro ments for special quotations.

\section{Northwestern Dent}

Northwestern Dent is a short season corn maturing in 90 to 95 days. This makes it a very desirable corn for sections where the time between the late and early frosts is short. The ears set 3 to 4 feet above the ground, are of medium size, average 7 to $91 / 2$ inches long and carry 12 to 14 rows of grain. The kernels are shallow and have a light reddish color with a copper yellow spot in the crown. The stalks grow 5 to feet high and are very thin and leafy. It is, therefore, especially wel adapted for fodder and bundle feeding but on account of the size of the cob and its shallow kernels it is not considered a husking corn.

Prices, not prepaid: $1 \mathrm{lb}, 15 \mathrm{c}$; 10 lbs. $85 \mathrm{c} ; 25$ lbs., $\$ 1.75$. Please write for general quantity prices or submit list of your requirements for special quotations.

\section{Golden King}

Golden King is an early dent corn, being an improved type of Swadley. It matures in 90 days and is well adapted to short seasons and dry lands. The stalks grow to a medium height with ears about three feet from the ground. The ears are medium sized, about 10 inches long. The grains are deep and broad, light yellow color merging to pale yellow at the cap are deep and broad, light yellow color merging to pale yellow very desirable for whole grain feeding.

Prices, not prepaid: 1 lb., 15c; 5 lbs., 50c; 10 lbs., 80c; 25 lbs., $\$ 1.50$. Please write for general quantity prices or submit list of your requirements for special quotations.

\section{Reid's Yellow Dent}

Reid's Yellow Dent bears the name of its originator, James L Reid, of Illinois, who many years ago fixed a type that experts have failed to change for the letter. It requires about 110 days to mature and should be planted in warm, quick soils exposed to the south, in sections not subject to early frosts. The ears are large, averaging 10 to 11 inches in length, slowly tapering, and have a well rounded butt. The grains are yellow, very deep and closely packed on a small cob, the tip and butt of which they almost entirely cover. The leaves and stalks of Reid's Yellow Dent make an excellent fodder and ensilage and it is rapidly becoming the most popular all-around purpose corn that can rapidly becoming the most popular all-around purpose corn that can 25 lbs., \$1.50. Please write for general quantity prices or submit list of your requirements for special quotations. 


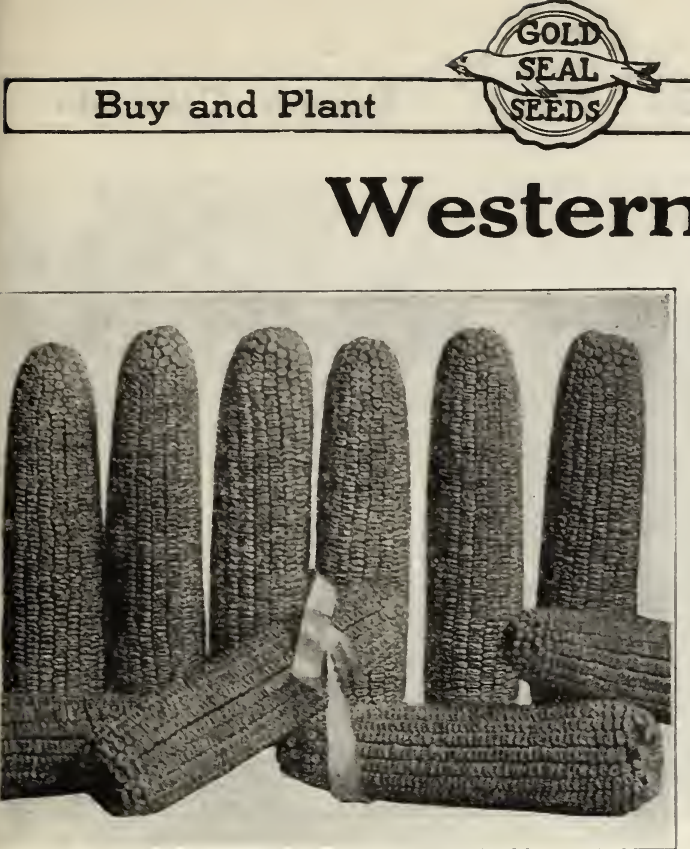

King of the Earliest.

\section{Seed Corn}

\section{King of the Earliest}

King of the Earliest is an early yellow dent corn that matures in 90 to 95 days. As it withstands adverse conditions to a marked desree, it in very suitable for early planting and can be safely planted as far north as any dent corn. The ears are medium sized, 9 to 10 inches long, with 18 to 24 rows of kernels. The cob is small. The grains are deep, somewhat rough, and of a deep yellow color and closely set on the a good height, are small and leafy. The ears set about four feet from the ground.

Prices, not prepaid: $1 \mathrm{lb}, 15 \mathrm{c} ; 5$ lbs, $50 \mathrm{c}$; 10 lbs, $80 \mathrm{c} ; 25$ lbs, $\$ 1.50$ Please write for general quantity prices or submit list of your requirements for special quotations.

\section{Gehu Flint}

Gehu is a vellow, dxarf flint corn that grows 4 to 6 feet high and matures in 80 to 90 dars. It is not renerally used as a husking corn as the ears set close to the ground, but this feature makes it very desirable for early hogging down. It usually produces more than one ear to the stalk. The ears are 5 to 7 inches long, $4 \frac{1}{2}$ to $5 \frac{1}{2}$ inches in circumference and very tapering. The kernels are shallow, smooth, hard and of an orange or dark yellow color. It is the earliest yellow corn.

Prices, not prepaid: $1 \mathrm{lb}$, , 20c; $5 \mathrm{lbs}$., $75 \mathrm{c} ; 10 \mathrm{lbs} ., \$ 1.00$. Please write for general guantity prices or submit list of your requirements for special quotations.

\section{Calico}

Calico is a medium early, mixed dent corn maturing in about 100 days. The ears are large, 9 to 12 inches long and average twenty mows of grain but the cob is small. The kernels are variegated being rows of grain but the cob is small. The kernels are stalks are very leafy and attain a height of six to eight feet. The ears are carried high. Calico corn has a high protein content making it a very effihigh. Calico corn has a high protein

ient feed and it is relished by stock.
Prices, not prepaid: $1 \mathrm{lb}$., 20c; 5 lbs., 75c; $10 \mathrm{lbs} ., 90 \mathrm{c}$; $25 \mathrm{lbs}$. , \$1.85. Please write for general quantity prices or submit list of your requirements for special quotations.

\section{Hickory King}

Hickory King is a very long season variety of white dent corn requiring at least 120 days to mature and for this reason is only recommended for planting in southern districts. It grows very tall. The ears are large, set about six feet from the ground with 16 to 18 rows of large, deep, broad kernels. The cob is white.

Prices, not prepaid: 1 lb., 20c; 5 lbs., 75c; 10 lbs., \$1.25. Please write for general quantity prices or submit list of your requirements for special quotations.

\section{Hartner's Rainbow Flint}

This is an early maturing corn and is very desirable for dry lands and short seasons. It is a flint, resembling White Australian in habit and size of kernels. The grains are variegated and highly colored. This year's crop is well matured and shows a germination

Prices, not prepaid: $1 \mathrm{lb} ., 15 \mathrm{c}$; 5 lbs., 50c; $10 \mathrm{lbs}$., 90c. Please write for general quantity price or submit list of your requirements for special quotations.

\section{Squaw}

Squaw corn is supposed to be a mixture of the various sorts once grown by North Dakota Indians. It is sometimes called Blue Squaw. It is very early, requiring not over 90 days to mature and is a very vigorous plant. The ears are small, averaging about eight inches long, set close to the ground, and carry eight rows of grain. The kernels are somewhat shallow, rounded smooth, and finty and are a mixture of blue, white, and yellow colors. Squaw corn is adapted for hog or sheep pasture. It yields much better than would be expected from such a short plant. In sections where the growing son is short it is the only kind of corn that will make grain.

Prices, not prepaid: $1 \mathrm{lb}$, 20c; 5 lbs., 75c; $10 \mathrm{lbs} ., 90 \mathrm{c} ; 25$ lbs. \$1.85. Please write for general quantity prices or enbmit list of your requirements for special quotations.

\section{Pride of the North}

Pride of the North is a good variety of extra early yellow dent corn that originated in Northern Iowa more than thirty years ago. It matures in eighty to ninety days. The ears are set low, about one-third of the length of the stalk above the ground. They are medium to small sized, with deep sellow kernels set solidly on a small bright red cob. Two or more good, well developed ears are frequently found on a single stalk and sometimes there will be three to four stalks to the hill. The stalks are small, well proportioned, to four stalks to the hil. Prie stalks are small, well proportioned, with credit and is very popular for early feed or for late planting. Prices, not prepaid: $1 \mathrm{lb}$., 15c; $5 \mathrm{lbs}$., 50c; $10 \mathrm{lbs}$., 80c; $25 \mathrm{lbs}$. \$1.50. Please write for general quantity prices or submit list of your requirements for special quotations.

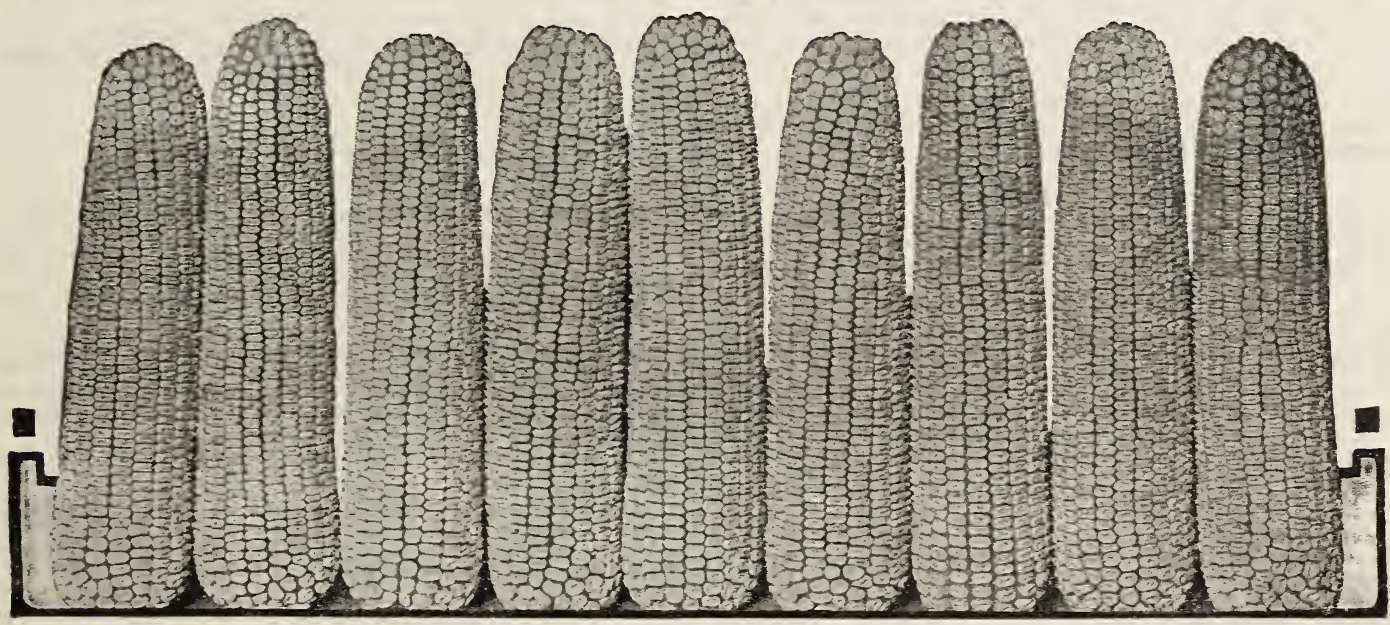

Pride of the North. 


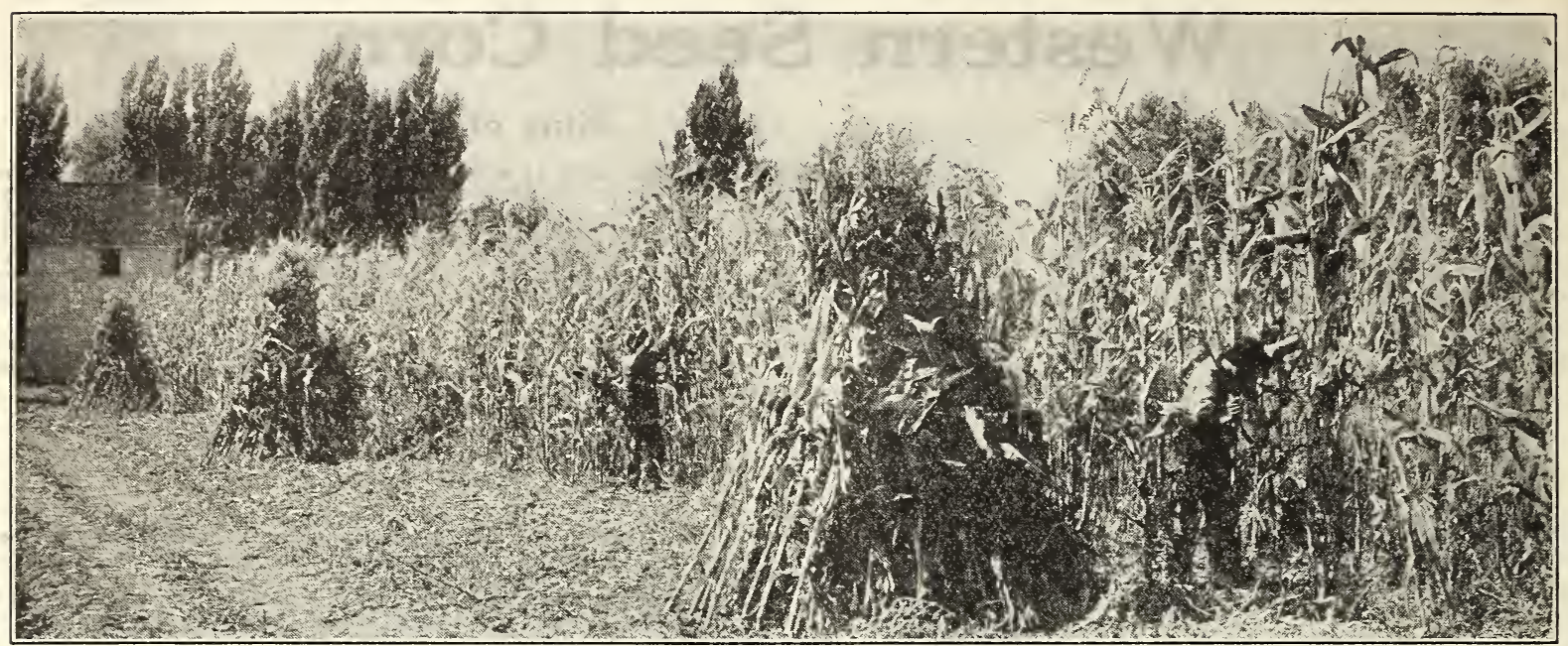

\section{Western Seed Corn}

CORN IS A VERY PROFITABLE SILAGE CROP.

The use of the silo is recommended for all parts of the West where crons can be grown. To secure the greatest profit from the soil, the farmer must keep more or less live stock and to do this, he must provide abundance of feed for all seasons. In the dry land districts, for this reason, the silo is especially serviceable. There are some seasons when the rainfall will be sufficient to produce more forage than immediate needs require. Every bit of this surplus forage should be and can be preserved for a lean year. This can best be done by the use of the silo.

After corn has been laid by scatter sweet clover between the rows, covering it light with a drag such as the branch of a tree or a small bush. If conditions are right, the increased yield of corn, the Fall pasturage from the clover, the green manure to be plowed under in the Spring as food for the succeeding crop, will make the planting well worth while. Try it and you will be a sweet clover fan.

\section{HARVESTING CORN FOR SILAGE}

Corn that is intended for silage should be allowed to grow as late as the season permits, or until the kernel has become hard and dented. The stalk is usually green as late as this stage. Many experiments have been conducted by The Colorado Agricultural College which show that a greater amount of feed of a better quality can be obtained from silage when it is made from corn cut at this etage of maturity. This silage will keep more easily, too.

\section{lowa Silver Mine}

Iowa Silver Mine is a white dent corn maturing in 100 to 110 days. It is so well and favorably known that it is often referred to as "The National Corn." The ears are large, 9 to 12 inches long, averaging 20 rows of grain. The cob is small and white. The kernels a re deep, white and rather smooth, dented but not hackle crowned. They are set solidly on the cob and almost cover the butt and tip. Stalks are of medium height to tall, very leafy with broad blades, often bearing two ears. Iow silver Mine has a heavy deep blades, often bearing two ears. Iowa silver Mine has a heavy deep root system. This enables it to withstand drought and adverse con-
ditions exceedingly well. It is a good yielder and is highly recommended for silage purposes.

Prices, not prepaid: 1 lb., 15c; 5 lbs., 50c; 10 lbs., 80c; 25 lbs. $\$ 1.50$. Please write for general quantity prices or submit list of your requirements for special quotations.

\section{lowa Gold Mine}

Iowa Gold Mine is a yellow dent ensilage corn maturing in 110 days. It is very similar to Improved Leaming and can not be easily distinguished from it. Prices are the same as for Leaming.

\section{Colorado Giant Fodder}

Colorado Giant Fodder is a white dent ensilage corn with large ears, big leafy stalks and deep kernels. It matures in about 100 days and is an elegant corn for ensilage purposes as it produces an immense tonnage of excellent quality silage. The grain will generally mature well enough to make the silage rich with protein content. It should be planted freely by dairymen and stockmen equipped with silage facilities. When properly cultivated in favorable seasons the stalks will attain a height of 10 to 12 feet. The leaves are broad and long; the ears average 9 to 10 inches with 10 to 20 rows of kernels.

Prices, not prepaid: $1 \mathrm{lb}$, 15c; 5 lbs., 50c; $10 \mathrm{lbs} ., 80 \mathrm{c} ; 25$ lbs. $\$ 1.50$. Please write for general quantity prices or submit list of your requirements for special quotations.

Valuable information about Merko, one of the newer Seed Corn disinfectants, will be mailed on request.

\section{Red Cob Enśilage}

Red Cob Ensilage is a pure white dent corn with a red cob. It matures in 110 to 115 days. The ears are large, 9 to 12 inches long and deep white kernels, somewhat smooth. The stalks grow 10 to 14 feet high with many broad succulent leaves, producing an immense tonnage of excellent quality silage. We recommend Red Cob Ensilage Corn for silage purposes.

Prices, not prepaid: i lb., 20c; 5 lbs., 75c; 10 lbs., 90c; 25 lbs., your requirements for special quotations.

\section{Improved Leaming}

Improved Leaming is a yellow dent corn and a general favorite with grain is rich in protein and oil and the large, leafy stalks make an immense tonnage of fodder or silage. Ears are rather large, 10 to 12 inces in length and gverage 20 to 24 rows of grain. They are well filled out. Grains are deep wedge shaped, closely set and have a deep, rich yellow color with a reddish cast. The stalks attain a height of 10 to 12 feet and are very strong with broad leaves.

Prices, not prepaid: 1 lb., 15c; 5 lbs., 50c; 10 lbs., 80c; 25 lbs. $\$ 1.50$. Please write for general quantity prices or submit list of your requirements for special quotations.

\section{Eureka Ensilage}

Eureka Ensilage is a large kerneled, white dent corn. It grows 12 to 15 feet high, is very leafy, and produces an enormous tonnage of succulent fodder. It bears one to two ears to the stalk that frequently measure over 12 inches. It is a long season corn and should be planted only with the hope of getting abundant fodder. It will require considerable plant food to produce such a sturdy corn, so choose good ground for Eureka Ensilage.

Prices, not prepaid: $1 \mathrm{lb} ., 20 \mathrm{c} ; 5 \mathrm{lbs} .75 \mathrm{c} ; 10 \mathrm{lbs} ., 90 \mathrm{c} ; 25 \mathrm{lbs}$. Prices, not prepaid: Please write for general quantity prices or submit list of
1.85. Plest your requirements for special quotations.

\section{Pop Corn}

WHITE RICE POP CORN is a very handsome and prolific variety. The ears are five to seven inches long and the kernels are long and pointed, somewhat resembling a grain of rice. There is generally a good demand for this corn for popping.

Large packet, $10 \mathrm{c} ; 1$ lb., 20c; 5 lbs., 75c; 10 lbs., \$1.25. Not postpaid.

LARGE SPANISH POP CORN is much larger grained than White Rice and when popped makes a larger, coarser flake. The seed is rounded, smooth and flinty. In its growth and habits Spanish Pop Corn resembles the common varieties of flint corns. There is a very strong demand for this corn for popping.

Large packet, 10c; 1 lb., 20c; 5 lbs., 75c; 10 lbs., \$1.25. Not postpaid.

BABY RICE POP CORN is known as Baby or Hulless, Japanese Rice, Baby Rice or Japanese Hulless. It is a dwarf growing, heavy yielding variety, and is considered the choicest pop corn grown, due to its fine flavor and the absence of hull or shell. Ears are peculiar use Baby Rice.

Large packet, 10c; 1 lb., 25c; 5 lbs., \$1.00. Not postpaid. 
 \\ Western Field Peas and Vetch}

\section{Field Peas}

No other grain crop, except perhaps oats, No other grain crop, except a variety of uses. The grain is possessed of a relatively high The grain is possessed of a relatively high feeding value, and the same is true of the straw. As a pasture for certain kinds of
livestock, peas may be made to serve an excellent purpose. The value of the crop for soiling and fodder uses is excelled only by clover. There is no kind of livestock on the farm to which peas cannot be fed to advantage.

\section{San Luis Valley Peas}

This variety is also called Colorado Stock Peas, and has been grown for years in the San Luis Valley in Colorado. The stockgrowers in these regions found them valuable for fattening hogs and sheep. The custom was to allow the stock to graze on the pea fields eating the vines and seed. Pea fed pork is much sweeter and finer grained than corn fed. Recent years have seen a big demand for these peas as a food, and large quantities have been shipped to Eastern and foreign markets.

This is without a doubt the best stock pea to grow in the West. It produces a large quantity of vines, that make a fine hay, and the It produces a larger sed about sor hay it may be sown as late as July, when 80 pounds per acre, but for hay it $\mathrm{m}$

100 pounds per acre is usually sown. 10 lbs, $\$ 1.00$. Please write for general quantity prices or submit list of your requirements for special quotations.

\section{Dry Land Peas}

SOUTHERN BLACK-EYED PEAS (Large). The most popular and most extensively grown of all Black-Eye varieties. The seed resembles a bean in shape. They make a large vine growth and are an excela thesirable and healthful table dish and are in great demand during the Winter. They are also table dish and are in great demand during the Winter. They are also used green during the

eye Peas in the garden.
Prices: Lb., 20c; 5 lbs., 90c; 10 lbs., \$1.50. Please write for general quantity prices or submit list of your requirements for special quotations.

\section{Canada Field Peas}

Are one of the very best soiling crops for the North. They are sometimes grown alone, but the most satisfactory dairy results comes from sowing with oats, rye or barley. They make good ensilage, and from sowing with hardy and may be sown early in the Spring, and will be ready to hardy and may be

Pric es: Lb., 20c; 5 lbs., 90c; 10 lbs., \$1.50; 25 lbs., \$2.75. Please write for general quantity prices or submit list of $\mathrm{y}$ our requirements for special quotations.

\section{SOIL FERTILITY}

Inoculate your Alfalfa, Sweet Clover, Soy Beans, Vetch, Peas, Beans, Clovers and all other legumes (pod-bearing plants), with McQueen's Dust-Kote Legume Inoculator.

Inoculation hastens maturity, increases the crop, improves its quality, enriches the soil and saves fertilizer bills.

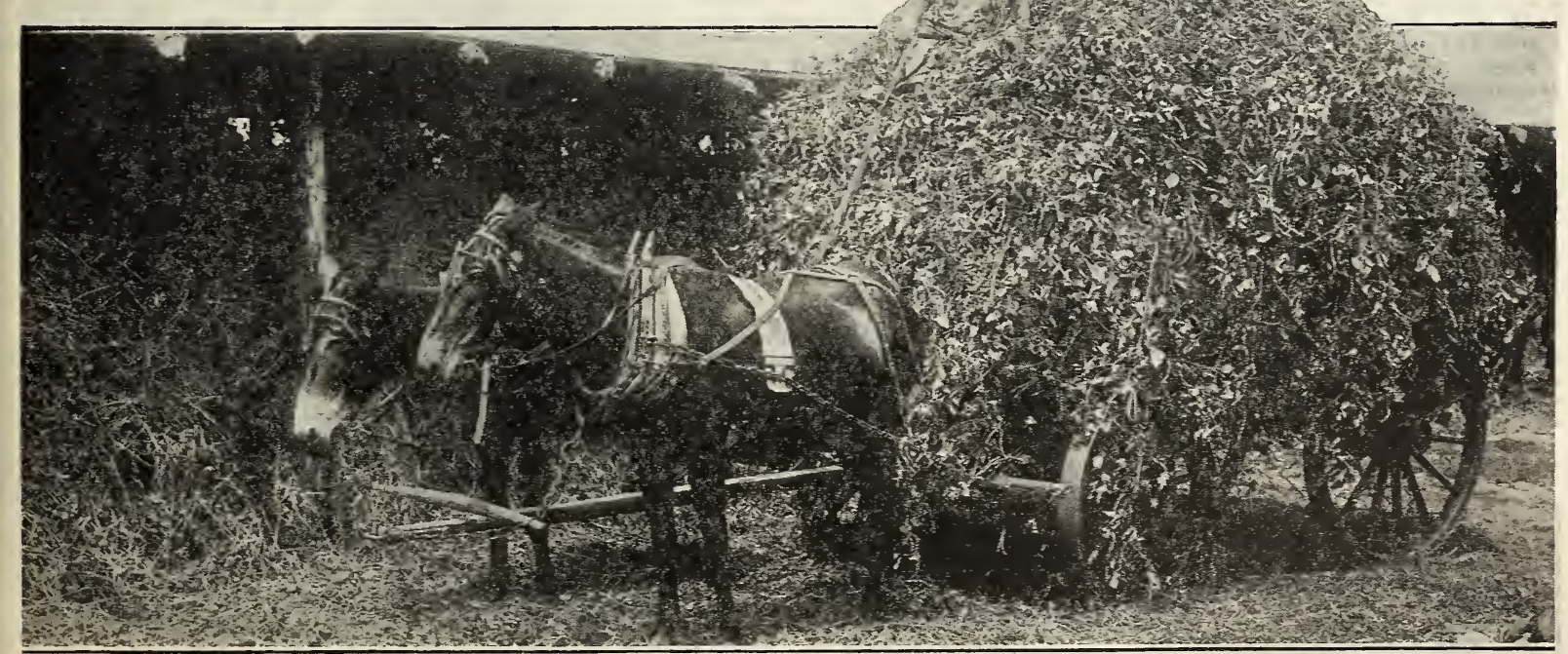




\section{Western Field Beans}

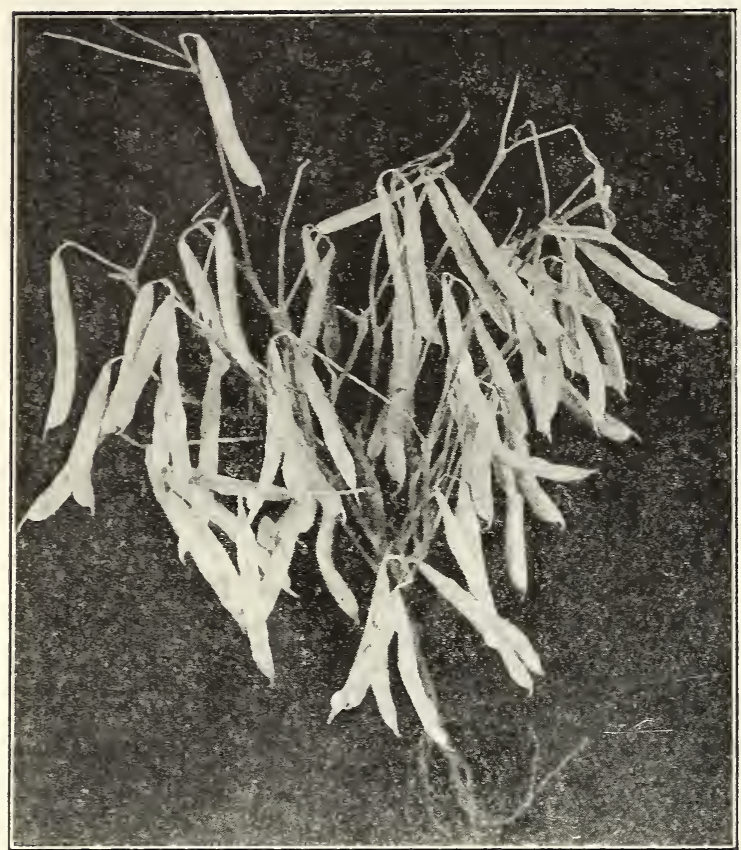

Navy Beans.

\section{Pinto Beans (Mexican)}

The leading commercial bean of the West. The Pinto Bean will grow on dry land and yields as high as 1,100 pounds per acre have been reported, while on irrigated land, 2,500 pounds have been secured from one acre. It is easily grown and requires little attention. There is now an established demand from Eastern and Southern markets for this variety. Our seed stock is select, hand picked and grown in Colorado on dry land.

Prices: Lb., 20c; 5 lbs., 75c; 10 lbs., \$1.25. Please write for general quantity prices or submit list of your requirements for special quotations.

\section{Red Kidney Beans}

Will produce crop of first class beans and are a success in the West. They are excellent canners and richly flavored. They are found in every grocery store and are so well known that a description is useless. Their habits of growth are similar to the Pinto. There is quite a large local demand for the dry beans,

Prices: Lb., 25c; 5 lbs., $\$ 1.00 ; 10$ lbs., $\$ 1.75 ; 25$ lbs., $\$ 4.00$. Please write for general quantity pricss or submit list of your requirements for special quotations.

\section{Broad Windsor Beans}

These beans are hardy and can be treated in about the same manner as peas. They should be planted in rows from twelve to eighteen inches apart, allowing eight inches between plants. Broad Windsor Beans are very much in favor in Europe, where they are cooked while green. but also the dried bean Even the pods, while quite young, are eaten. The beans have an agreeable flavor and are of high nutritive value.

Prices, (Hand Picked): Lb., 25c; 5 lbs., \$1.15; 10 lbs., \$2.25.

\section{Red Mexican Beans}

These are similar in size and shape to the Pinto Bean and in their habits and growth resemble them very much. There is quite a demand for these beans for Chili. They are excellent cookers. A small patch would undoubtedly bring satisfactory returns.

Prices: Lb., 25c; 5 lbs., $\$ 1.00 ; 10$ lbs., $\$ 1.75$. Please $w$ rite for general quantity prices or submit list of your requirements for special quotations.

\section{Navy or Pea Beans}

The best known white bean in the world. More Navy Beans are consumed than all other varieties combined. They always command a higher price than the other varieties, except Limas.

They produce almost as much as Pinto Beans, and are a sure crop under ordinary conditions. They make good yields on dry lands, and large yields when grown under irrigation.

Prices: Lb., 25c; 5 lbs., $\$ 1.00 ; 10$ lbs., $\$ 1.75$. Please write for general quantity prices or submit list of your requirements for special quotations.

\section{Great Northern or Large White Marrowfat}

This bean is similar to the Navy and often sold as such. It is also known as White Mexican, White Kidney and Western White Wonder. It is larger than the Navy and will make a crop where the Navy would fail. It is a heavy yielder and the beans have a very fine flavor when cooked or baked. This variety is in great demand as a dry bean for Winter use and will give satisfaction great demand as irrigated land. Our seed is Colorado grown, selected hand picked.

Prices, lb., 25c: 5 lbs., \$1.00; 10 lbs., \$1.75. Please write for general quantity prices or submit list of your requirements for special quotations.

\section{Stock Beans}

\section{Early Soja Beans}

A valuable forage plant, little affected by heat and drought. Is one of the most nutritious of all vegetable products. It will produce from 20 to 30 bushels to an acre. For pasturing or feeding as green fodder it is very valuable; also g good fertilizer.

Prices, 1 lb., 25c; 5 lbs., $\$ 1.00$; 10 lbs., \$1.75. Please write for general quantity prices or submit list of your requirements for special quotations.

\section{Ito San Sojas}

A very satisfactory variety to grow in a short season. Produces seeds fairly well, and matures in 95 to 100 days Branches well, so ss to be very easily harvested. The plants are of medium size, averaging 25 to 30 inches in height. Will mature as far north as Wisconsin and Michigan.

Prices, 1 lb., 25c; 5 lbs., $\$ 1.00$; 10 lbs., \$1.75. Please write for general quantity prices or submit list of your requirements for special quotations.

\section{Hollybrook Early Sojas}

Make a quicker growth and mature their crop two weeks earlier than the Mammoth Yellow Soja. It makes a large yield both of forage and peas and the added advantage of its earliness makes it a most distinct and valuable acquisition. Sown as a forage or hay crop it is much easier to eure and handle, and makes even a more nutritious crop than cow peas.

Prices, 1b., 25c; 5 lbs., $\$ 1.00 ; 10$ lbs. \$1.75. Please write for general quantity prices or submit list of your requirements for special quotations.

Corn, Wheat, Oats, all crops, are benefited by the nitrogen deposit placed in the soil by inoculated legumes. But remember this: Only inoculated legumes are soil builders and have the means of taking this free nitrogen from the air. Without the proper bacteria on the roots, legumes are actually soil robbers. For building up worn out soils, or maintaining proper soil fertility in good soils-Grow legumes and INOCULATE with McQueen's Dust-Kote Legume Inoculator.

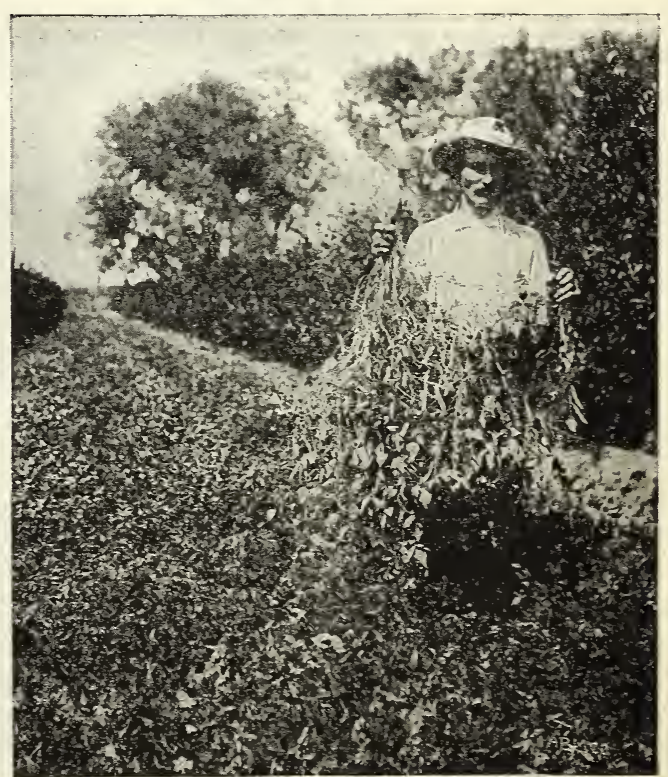

Soja Beans. 

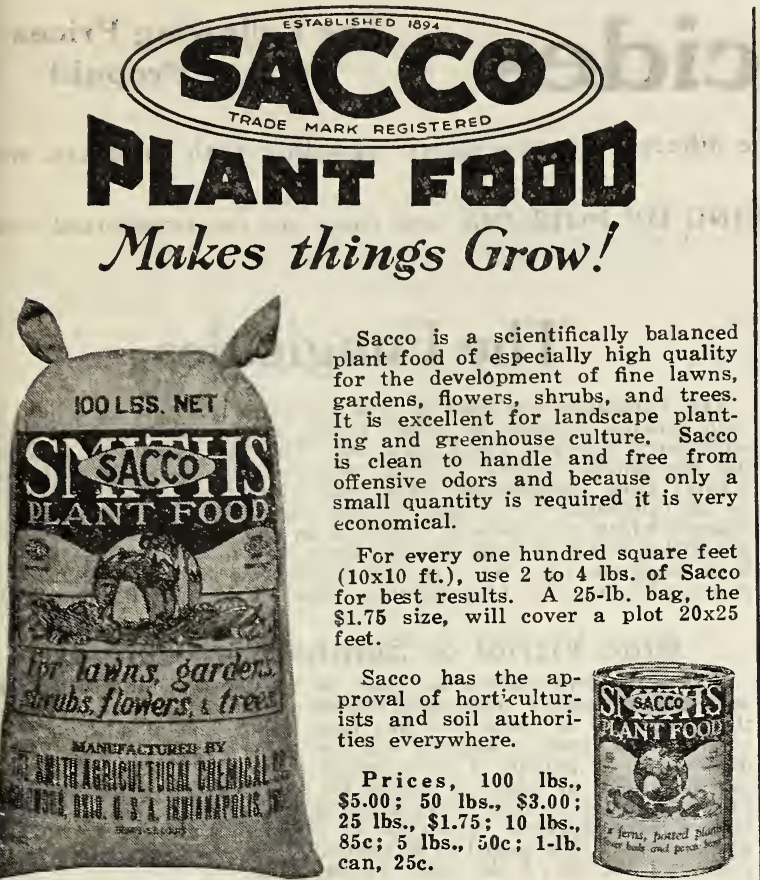

Sacco is a scientifically balanced Sacco of especially high quality for the development of fine lawns, gardens, flowers, shrubs, and trees. It is excellent for landscape planting and greenhouse culture. Sacco is clean to handle and free from offensive odors and because only a small quantity is required it is very economical.

For every one hundred square feet $(10 \times 10 \mathrm{ft}$.), use 2 to $4 \mathrm{lbs}$. of Sacco for best results. A 25-lb. bag, the s1.75 size, will cover a plot $20 \times 25$ feet.

Sacco has the approval of horticulturists and soil aut
ties everywhere.

Prices, 100 lbs, $\$ 5.00$; 50 lbs., $\$ 3.00$; 25 lbs., \$1.75; 10 lbs. $85 \mathrm{c} ; 5$ lbs., $50 \mathrm{c}$; $1-1 \mathrm{~b}$. can, 25c.
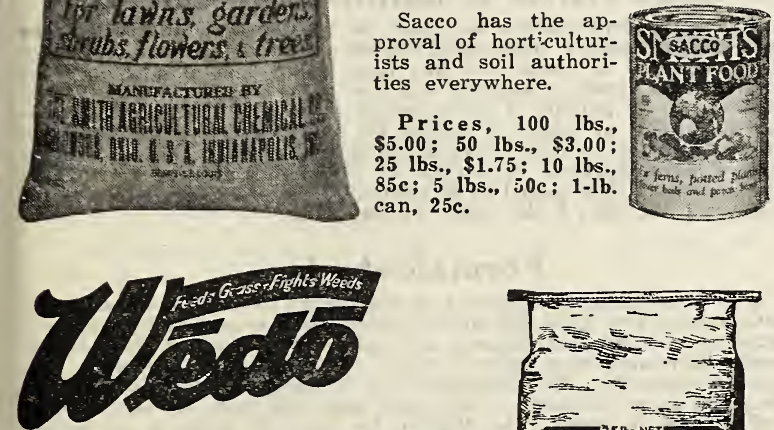

Wedo is an ideally balanced fertilizer formulated especially for weed control in lawns. Wedo feeds grass and fights weeds. It not only supplies the lawn with an ideally balanced feeding ration that produces a healthy, rugged tron the produces but it contains elements that have proven to be effecments that have proven to be effecExperiments proving the value of Wedo have been conducted to show that the common weed pests of our lawns thrive best in a sweet or alkaline soil. Through the consistent use of proper fertilizing elements that overcome this alkaline con-

dition, reverting the soil to a degree of acidity or sourness, weeds fail to thrive and are gradually crowded out by the strong healthy frow to to 100 square feet.

Prices are not prepaid: 25-lb, bag, $\$ 2.00 ; 50$ lbs., $\$ 3.75 ; 100-1 b$. bag, $\$ 6.50$.

SUPERPHOSPHATE: There are two main types of Phosphatic Manures-Superphosphate and Bone Meal. Superphosphate is a water soluble combination of Phosphoric Acid and Lime which is forme formed by the action of Sulphuric Acid on Raw

th one of the elements requited in a balate other ingredients. They accumulate in the seeds and liberal applications of phosphates hasten maturity. Superphosphate is an efficient fertilizer element for lettuce and truck crops, cereal crops and alfalfa.

Write for prices stating quantity desired.

BONE MEAL-Contains Phosphoric Acid and some Nitrogen. Prices: 4 lbs., 25c: 10 lbs., 50c; 25 lbs., $\$ 1.00 ; 50$ lbs., $\$ 1.60 ; 100$ lbs., \$2.75.

VIGORO is a specially prepared plant food for lawns, gardens, flowers, shrubbery and trees. It furnishes the proper plant food for a healthy vigorous growth. Vigoro should be applied at the rate of four pounds per 100 square feet and should be applied three times Prices, not prepaid, 5 lbs., 60c; 25 lbs., $\$ 2.00 ; 50$ lbs., $\$ 3.75 ; 100$ lbs., $\$ 6.00$.

PULVERIZED SHEEP MANURE-Contains Nitrogen, Phosphoric Acid and Potash. One of the most complete fertilizers known. A wonderful soil builder. Prices: 10 lbs., 25c; 25 lbs., 60c; 50 lbs., $75 \mathrm{c} ; 100$ lbs., $\$ 1.35$.

NITRATE OF SODA-Contains Nitrogen and promotes rapid growth. Should be applied when plants are above the ground. Prices: $1 \mathrm{lb}$., $15 \mathrm{c} ; 10 \mathrm{lbs}$., $\$ 1.20 ; 100 \mathrm{lbs}$., $\$ 7.75$.
SULPHATE OF AMMONIA has been the standby of the fertilizer industry for years as a source of quick-acting Nitrogen in mixed fertilizers. It is the most concentrated nitrogenous top-dressing fertilizers. It is the most concentrated nit $203 \%$. It resembles clean. available. Ammonia $25 \% \%$, nitrogen $20 \%, \%$. It resembles clean, dry sand and is easily applied. Even spreading brings instant food to every rootlet. It is an excellent lawn dressing and equally as efficient in the field, orchard and garden. It furnishes plant food (nitrogen) that promotes a vigorous grass growth that crowds out weeds, besides creating increased soil acidity in which common of acid, find life a burden, and in time die out.

Make the first application in early Spring (April); another, thirty days later, and the third in early Fall (September).

A heaping teaspoonful of Sulphate of Ammonia weighs one ounce.

A pint measure holds one pound. An ounce will fertilize twelve to fifteen square feet and one pound to 200 square feet.

Prices, not prepaid, 1 lb., 15c; 5 lbs., 50c; 10 lbs., 75c; 25 lbs. $\$ 1.50 ; 50$ lbs., $\$ 2.75 ; 100$ lbs., $\$ 4.50$.

BLOOD MEAL-Dried Blood Meal, applied as a top dressing, produces a quick growth. It is well adapted to greenhouse use. Prices: 3 lbs., 25 c; 25 lbs., $\$ 1.75 ; 50$ lbs., $\$ 3.25 ; 100$ lbs., $\$ 6.00$.

\section{Stim-U-planT}

Growers of fine flowers, shrubs, and vegetables for the best markets and for exhibition, fertilize and stimulate them frequently, a kets a planT, an odorless, highly concentrated plant-food, in tablet form, with guaranteed chemical analysis of 11 per cent nitrogen, 12 pe cent phosphoric acid, 15 per cent potash. The proportions are accurate, there is no wasted filler, and in this form you apply plant food exactly when and where and as needed.

Order Stim-U-planT tablets with your seed and plant order.

Prices: Trial size, $15 \mathrm{c}$; 'small size, 25c; 100 tablets, $75 \mathrm{c} ; 1000$ tablets, \$3.50.

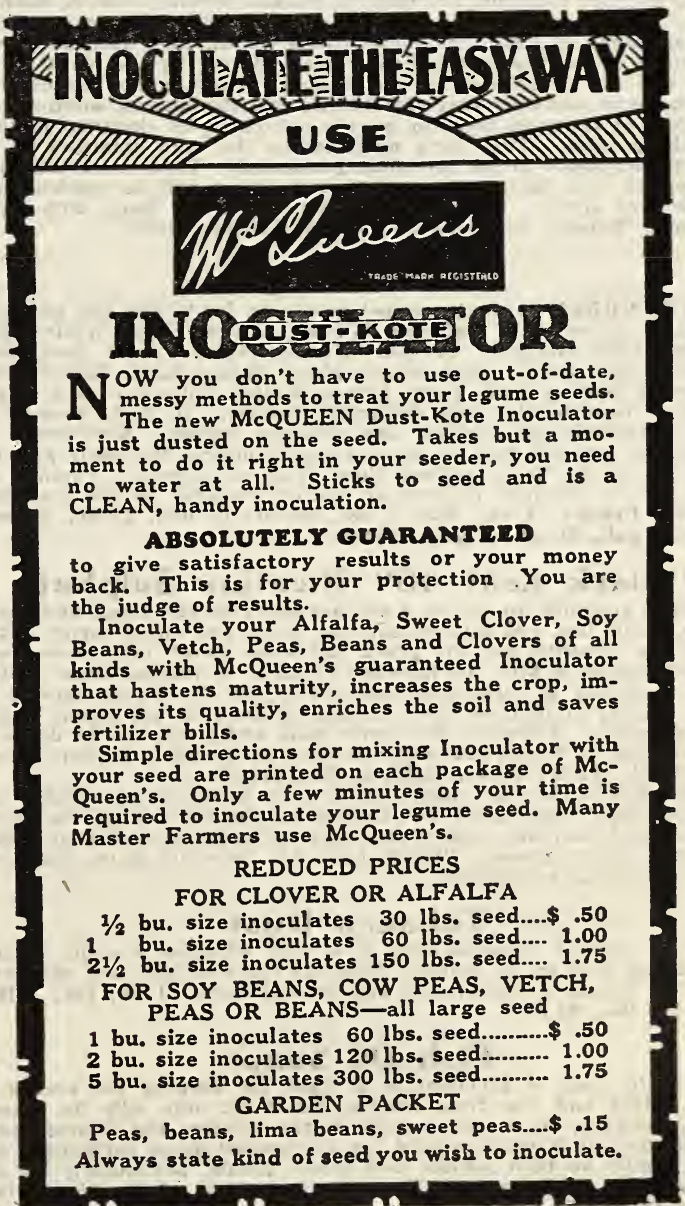




\section{Poisons Cannot Be Sent by Mail}

Complete authoritative circular matter, compiled by the different manufacturers regarding their products, will be furnished as requested without charge.

Existing Postal Regulations PROHIBIT THE MAILING OF POISONS, and they can be transported only by freight or express.

\section{The Poisons}

The poisons are used against surface chewing or biting insects such as most caterpillars and leaf beetles, potato bugs, tomato and tobacco worms, apple codling moths, bud-worms, fruit worms, etc. No spraying material is absorbed by the juices of the plant. They are sprayed upon the leaves and remain in the form of a thin film

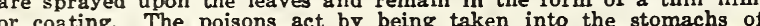
the insects while eating. In this group come Paris Green, Arsenate the insects

\section{Powdered Arsenate of Lead}

Is an effective insecticde for leaf eating insects on tender foliage. Prices, not prepaid: $1 / 2 \mathrm{lb} ., 25 \mathrm{c} ; 1$-lb. carton, 40c: 4-lb. bag, \$1.25. Complete insecticide catalog and prices on larger quantities on application.

\section{Paris Green}

Is a strong effective poison for leaf eating insects. Prices, not prepaid, 1/4-1b. fibre carton, 20c: 1-lb. fibre carton, 50c; 4-1b. metal containers, \$1.95. Complete insecticide catalog and prices on larger quantities on application.

\section{The Contact Solutions}

The contact solutions are used to combat sucking insects, such as plant lice or aphis, thrips, leaf-hoppers, apple red bugs, and the various kinds of scale. As these insects obtain their food by inserting tubes or bristles under the surface and sucking the plant juices they will not be affected by the poisons. Fortunately this class of insects have generally very soft bodies, and the contact solutions ar designed to act upon these by caustic action, or by clogging up their breathing tubes. They have no effect on the hard exteriors of the insects mentioned in the preceding paragraph. These materials must be applied very thoroughly so that each insect will be touched by a particle of spray. In this group come Fish Oil Soap, Dry LimeSulphur, Tobacco Solutions and special Tobacco Dusts.

\section{Ever-Green}

EVER-GREEN is recommended especially for killing the following insects: Cut-worms, Cabbage Worms, Green Flies, White Flies, Thrips, Leaf Hoppers, Currant Worms, Aphis (plant lice), Rose Chafer, Rose Slug:, Pear Slugs, Mealy Bugs, Mites, Red Spiders, Japanese Beetles, Leaf Tiers, Potato Beetles, Squash Beetles, Aster Beetles, Bean Beetles, and Cucumber Beetles. In fact, Ever-Green kills practically all sucking and chewing insects. Ever-Green diluted 1 to 100 and sprayed around plants during the early growing period will effectively protect them from cut-worms. Further deperiod will effectively protect them from cut-worms. Further details can be obtained in circular matter prepared by the manufac-
turers. Prices: 1 oz., 35c; 6 ozs., $\$ 1.00 ; 16$ ozs., $\$ 2.00 ; 32$ ozs., $\$ 3.50 ; 1$ gal., $\$ 13.00 ; 5$ gals., $\$ 50.00$.

\section{"Black Leaf 40" Nicotine Sulphate}

This is splendid for use as a contact spray to kill green and wooly aphis, plant lice, red spiders, cabbage aphis and onion thrips. It is especially effective for the green aphis on sweet peas, roses, and apple trees, as it kills the insects as soon as it touches them; but if used according to directions does not injure the leaves, flowers or fruit. Spray apple trees when the tips of the buds are green, $3 / 4$ pint to 100 gallons of water. For sweet peas and roses, use 40 drops of the solution to 1 quart of water as soon as the pests appear. $1 \mathrm{oz}$. $35 \mathrm{c} ; 1 / 2 \mathrm{lb}$., $\$ 1.25$; 2 lbs., $\$ 3.25 ; 10$ lbs., $\$ 11.85$.

The world's largest manufacturers of nicotine insecticides announce that "Black Leaf 40 " painted on the top-side of the roosts will control body-lice. Saves the labor of handling each bird, either to dust, dip or grease. "Black Leaf 40 " does not harm the birds nor retard egg production.

\section{Tobacco Dust}

Finely ground Tobacco Dust is a very effective weapon against Aphis and Lice on all plants. Splendid fertilizer also and preventative for insects in the ground and around roots. $1 \mathrm{lb}$., 10c; 3 lbs. $25 \mathrm{c}$; 100 lbs., $\$ 5.25$.

\section{Fish Oil Soap}

Fish Oil Soap is excellent as a wash for keeping the trunks of trees bright and free from insects, for it not only kills the insects on the surface, but it penetrates into the crevices and destroys eggs and larvae. It is recommended for use against many varieties of the louse family on both outdoor and indoor plants, particularly for the Mealy Bug. Makes an excellent summer spray. 1 lb., 25c; 5 lbs. $\$ 1.00$ : 10 lbs, $\$ 1.75$.

\section{The Fungicides}

The Fungicides are used to give protection against infection by such fungous diseases as potato blight, grape mildew, apple scab strawberry leaf-spot, peach scab, etc. They act mainly by preventing the fungus "spores" (which correspond to the seeds of higher plants) from germinating when they alight on protected foliage. As all fungicides are preventives and not cures, do not wait until a disease, which you know is prevalent in the neighborhod, untul a disease, which ou know in is in many cases too late. In this group come Bordeaux Mixture in powdered form, Dry Lime-Sulphur, Blue Vitriol and Formaldehyde.

\section{Blue Vitriol or Sulphate of Copper}

This is a preventative of smut in your grain, and when the seed goes through a solution of vitriolized water the crop produced therefrom will be clean and free from smut. We handle only the crystal form ready to dissolve and use. One pound of Blue Vitrio dissolved in 20 gallons of water makes a suitable solution for treat ing 30 bushels of wheat or barley for smut. It is not so handy to prepare for use as Formaldehyde but it is somewhat cheaper and we believe more effective. A mixture of five pounds of Blue Vitriol and five pounds of lime added to 60 gallons of water is very effective for celery. 1 lb., 20c; 5 lbs., 85c: 10 lbs., $\$ 1.50$.

\section{Formaldehyde}

It is of pronounced efficiency in destroying disease germs affecting both animal and plant life and is successfully employed as a preventative of such fungous diseases as potato scab, onion and grain smuts, musty corn and other affected seeds, damping off of seedlings, club root of roses, etc., for the restraining of decay in vegetables, fruits, etc., and as an antiseptic wash and spray for bark diseases, canker and wounds in trees. The dilution for most purposes is one pound (1 pint) formaldehyde to 15 or 20 gallons of water. Formaldehyde is put up in pint or pound bottles and this quantity added to 40 gallons of water will treat 30 bushels of wheat or barley, or 40 bushels of oats for smut or 60 bushels of flax for wilt. 1-lb. can, 55e 5-lb. cans, $\$ 2.50$.

\section{Copper Carbonate}

Experiments by the extension service of the Colorado Agricultural College show that Copper Carbonate is very efficient for the control of Bunt or Stinking Smut of wheat. As it contains a higher per cent of copper than prepared formulas, it is not necessary to use so much. Two or three ounces of 52-54 per cent Copper Carbonate per bushel of grain is sufficient. The value of Copper Carbonate is determined by its metallic Copper content. Do not be misled into buying inferior carbonate. Copper Carbonate with less metallic Copper can be bought for less. 5 lbs.. $\$ 1.50$.

\section{Corona Coppercarb}

For killing smut spores in wheat Corona Coppercarb has been found to be highly efficient. It is a specially prepared product and nothing has to be added to it to get results desired. Circular matter giving authoritative information can be had on request. Six to eight ounces per bushel is recommended. Packed in $5 \mathrm{lb}$. cartons. Price, $\$ 1.00$ each; larger quantities quoted on request.

\section{Corona Merko}

FOR TREATING SEED CORN

Merko is a dust disinfectant for Seed Corn to rid it of molds and disease. Treatment with Merko permits earlier planting; prevents seedling rots; increases the stand and yield. Circular matter giving authoritative information with regard to Merko can be had on request. Include with Seed Corn orders.

\section{Bordeaux Mixture}

For fungous diseases. Prices, not prepaid: 1-lb. carton, 35c; 4lb. bags, $\$ 1.00$. Complete insecticide catalog and prices on larger quantities on application.

Dry Lime-Sulphur For dormant spraying against scale. Prices, not prepaid: 1 lb
$30 \mathrm{c} ; 5$ lbs. $\$ 1.20 ; 10 \mathrm{lbs}$., $\$ 2.10$. Complete insecticide catalog and prices on larger quantities on application. 


\section{Devoe "Sure-Noxem"}

For use on Cabbage, Cauliflower, Tomato Plants, Cucumber Vines, Melon Vines, Currant Bushes, Gooseberry Bushes, and other vegetables and shrubs of many kinds.

Not prepaid, sifter top can, 25c; 5-lb. bag, 75c. Write for prices on $100-1 b$. metal drums.

\section{Hammond's Slug Shot}

This is one of the oldest and most reliable insecticides on the This is oasily distributed by market. It comes in fine powdered form and is easily distrith water and used in a spray.

dusting, or can be mixed with water and used in a spray.
It is very effective in killing currant worms, potato bugs, cabbage worms, chicken lice, slugs, etc.

1 lb., put up in can with perforated top .............\$0.25 5 lbs., put up in packages... 1.25

10 lbs., put up in packages.

\section{Nicofume Liquid}

This is a highly refined solution of "free" nicotine, containing 40 per cent nicotine. This may be used both for spraying and fumigating. It is an effective remedy for green Aphis and other insects which infest Roses, Sweet Peas and other plants, when used at the which of water. Directions on rate of 1 to 2 teaspoonfuls to the gallon of water.

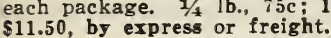

\section{Nicofume Paper}

By using this paper greenhouse men will find the destroying of lice, etc., very easy. It is a slow-burning paper, saturated with a tin box, $\$ 1.25 ; 144$-sheet cans, $\$ 5.00 ; 288$-sheet cans, $\$ 8.75$, postpaid.

\section{Powdered Sulphur}

It has been proven and so recommended by the University of California that if you sulphur your grape vines and orchards six times they will not be affected by Mildew or Red Spiders. Sulphur is a good fertilizer and beneficial results will be obtained if you incorporate a liberal quantity in the soil in your garden each Spring. porate a liberal quantity in the soil in

It will help to exterminate cut worms. $10 \mathrm{c}$; 100 lbs., $\$ 3.50$.

\section{Hydrated Lime}

Lime is a wonderful element for sweetening soils, correcting acid and sour soils and putting them in proper mechanical condition. Through the use of lime, a much thicker turf of Blue Grass can be
obtained. Scatter light and evenly 2 to 4 pounds per 100 square obtained. Scatter light and evenly 2 to 4 pound

Price, not prepaid: 10 lbs., 35c: 50 lbs., $\$ 1.00$.

\section{Common Sense Rat Exterminator}

Destroys rats under all conditions. They eat it in preference to any food. No stench. It dries up the carcass, leaving only the pelt.

It is a paste, not a powder. Easy to apply. It is the CHEAPEST, as so little is required. Price, $30 \mathrm{c}$, not postpaid.

\section{Moore's Prepared Poison Grain}

Certain and speedy destruction to ground squirrels, gophers, prairie dogs, rats, mice, etc and easy to use; cheap and will kill ten where dogs, rats, mice, etc., and easy to use; cheap and will kill ten where poisoning the best method, but it must combine three points. It must be something they will eat, thoroughly poisoned and placed where they will get it. Lb. can, 50c each; 10 lbs., \$3.75: 25-lb. drums, $\$ 7.50$, not postpaid.

\section{Mouse Seed}

Kills mice without bait, traps or muss. It is safest to use where there are children or pets. The seeds are unpleasant to the taste but are attractive to mice. Small package, $25 \mathrm{c}$.

\section{Gas Ball Rodent Killer}

Is a ball which, when lighted and rolled down into the burrow, pours forth a deadly poisonous gas that carries death to any living thing in the burrow. Although it means absolute destruction to rodents, it is perfectly safe for the farmer to handle and cattle cannot be injured or endangered by its use. It is non-explosive, does not deteriorate with age and is cheaper than similar material on the market. It kills the squirrel, gopher and prairie dog at small expense and no danger to stock and is non-poisonous to handle and a sure killer. Dozen, 60c; carton of 125, \$3.50, not prepaid. Write for prices on larger quantities.

\section{Grasshopper Poison Mash}

An effective formula for a poison mash for controlling grasshoppers furnished on request.

\section{Terro Ant Killer}

If you are bothered with ants use Terro. It will rid your place of ants in twenty-four hours. Used in the kitchen to keep these crawling insects from ice box and pantry. In stores and bakeries it prevents their appearance in candy cases, cake cases and ice cream cabinets. It saves flowers, shrubs and trees from injury. cream cabinets. It saves flowers, sh

\section{Increase Farm Profits and Gardening Pleasures}

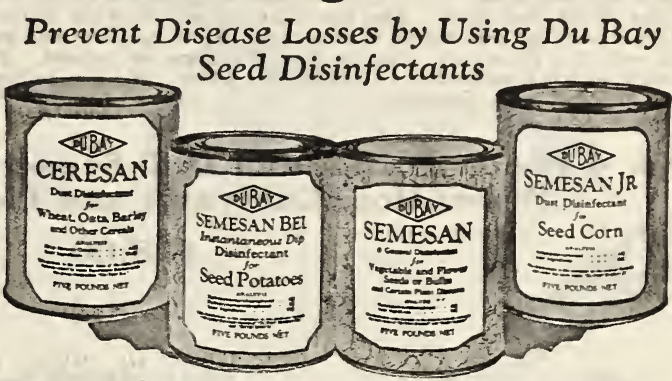

SEMESAN-for vegetable and flower seeds

Diseases often reduce germination and result in a poor stand, lowered quality and reduced yield of vegetables and flowers. Kill these harmful disease organisms on the seed with Semesan before planting. Semesan may be applied as a dust or liquid and is harmless to seeds. Effective in controlling damping-off of seedlings and certain cuttings. Full directions in can for use on vegetable and flower seeds and bulbs. Prices: 2 oz. \$.50; $1 \mathrm{lb} ., \$ 2.75 ; 5 \mathrm{lb}$., $\$ 13.00 ; 25 \mathrm{lb}$., $\$ 56.25$.

\section{SEMESAN BEL-for seed potatoes}

Potato diseases cause a loss equivalent to the yield of 1 acre in every 5 or 6 acres planted. Much of this loss can be prevented by treating seed before planting with Semesan Bel, the instantaneous dip disinfectant. Effective in controlling such seed-borne diseases as scab, rhizoctonia and black leg. Protects seed piece from rotting caused by certain soil borne organisms, improves germination and usually produces a bigger crop of better quality. One pound treats 16 to 22 bushels of seed. Prices: 4 oz., $\$ .50 ; 1$ lb., $\$ 1.75 ; 5 \mathrm{lb}$., $\$ 8.00 ; 25$ lb., \$31.25.

SEMESAN JR.-for seed field and sweet corn Our corn crop is reduced over 80 million bushels annually by diseases that are carried on the seed. Destroy these costly diseases by treating your seed corn with Semesan Jr. Simple, quick, effective. Costs only $21 / 2 \mathrm{C}$ an acre. Harmless to seed, does not slow up the rate of drop. Semesan Jr. destroys harmful disease organisms on the seed, protects seed from rotting in cold wet soil, makes earlier planting possible, controls seedling blight, reduces root and stalk rots and generally increases crop yields. Use 2 oz. per bushel of seed. 4 oz., $\$ .50 ; 1$ lb., $\$ 1.75 ; 5$ lb., $\$ 8.00 ; 25$ lb., $\$ 31.25$.

\section{CERESAN - for seed grains}

Why lose part of your grain crops through smuts and other diseases? Prevent them and protect your profits by treating all seed grains with Ceresan before sowing. Effective in controlling stinking smut and seedborne flag smut of wheat; seedling blight of cereals caused by seed-borne scab; smuts of oats; covered smut and stripe of barley; kernel smuts of sorghums and millets; and seed-borne stem smut of rye. Seed may be treated in spare time. Ceresan is harmless to seed and does not injure grain drills. Only 2 ounces needed per bushel of seed wheat, rye, sorghums or millets and 3 ounces for oats and barley. Prices: $1 \mathrm{lb}$., $\$ .75 ; 5 \mathrm{lb}, \$ 3.00 ; 25 \mathrm{lb}$., $\$ 12.50$.

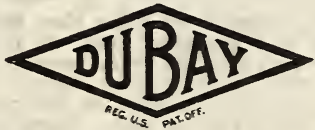

SEED DISINFECTANTS 


\section{Planet Jr. Farm and Garden Tools}

A Complete Catalog Sent on Request.

Space will not permit us to fully list and describe the entire Planet Jr. Line of Garden Tools. The few that we are showing below are the best known of this world famous line. However, we will gladly send a complete Planet Jr., Catalog free of charge, on request. There has been another reduction in prices this year. We are selling at factory price, f. o. b. Denver.

No. 4 Planet Jr. Hill and Drill Seeder, Wheel Hoe, Cultivator and Plow

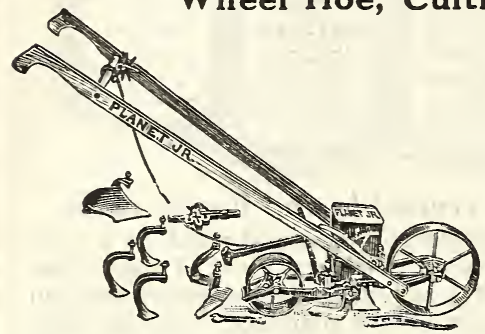

$\$ 18.00$

This accurate, easy running tool sows all garden seeds from smallest up to peas and beans in hills, 4, 6, 8, 12 or 24 inches apart, or in drills at the proper thickness and depth; rolling down and marking the next row all at one passage. By removing the seeder and substituting the tool frame you have a complete Single Wheel Hoe which plows, hoes, cultivates easily and thoroughly all through the season.

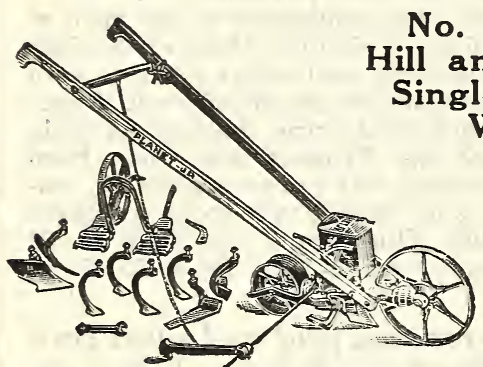

NO. 4D, HILL AND DRILL SEEDER, less the cultivating attachments, Holds $21 / 2$ quarts.

Weight, $50 \mathrm{lbs}$.

This is a splendid combination for a family garden, onion grower or large-scale gardener. As a Seeder it is the same as the No. 4 and does the same accurate work. Can be used as a Double Wheel Hoe to straddle rows. Hoes work close without injuring plants; cultivator teeth and plows do thorough work. Cutting tools specially hardened. Two aeres a day can be worked with this tool.

\section{No. 157 Two-Row Seeder}

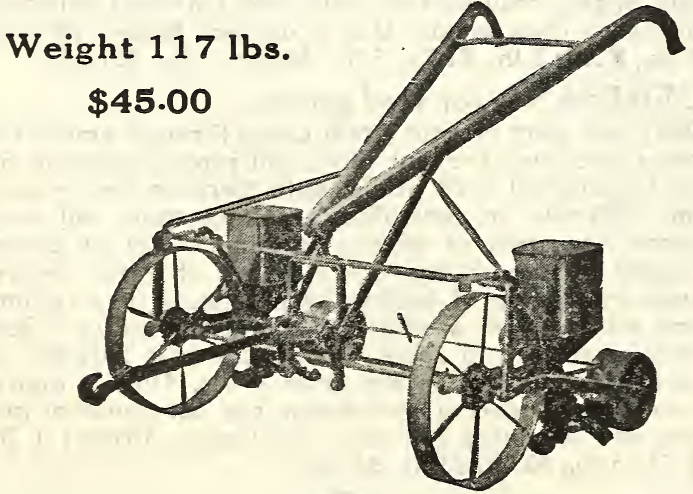

The No. 157 is now equipped with the New Multiple Seeder units which have a capacity of 5 quarts of seed. It is also equipped with a larger drive wheel which sets the frame several inches higher than formerly. This two-row seeder runs so lightly that one man can push it: but for all day work, a man or boy pulling on the front makes the draft extremely light for both. However, a horse is usually used. With the No. 167 you can sow rows from 10 to 36 inches apart. Clutches are provided to throw the feed wheels entirely out of gear for moving from place to place. Saves seed and makes the machine easy to handle.
No. 3 Planet Jr. Hill and Drill Seeder

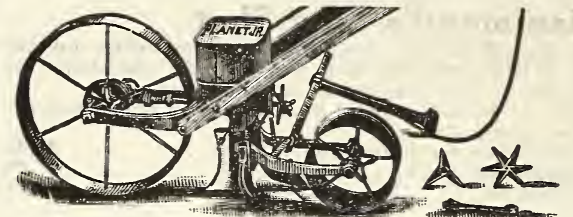

$\$ 17.50$

Holds 3 quarts. Weight, 43 lbs.

A favorite tool with onion growers, market gardeners and seedsmen. Has 15-inch steel driving wheel. The V-shaped opening plow is adjustable for depth and leaves the seed in a narrow line, permitting close, rapid cultivation with wheel hoes. Sows uniformly in drills or in hills $4,6,8,12$ or 24 inches apart. Where the acreage is sufficient to warrant the use of separate seeders and wheel hoes, we specially recommend this very popular drill.

No. 5 Planet Jr. Hill and Drill Seeder; larger capacity than No. 3. Price, $\$ 20.00$.

Planet Jr. No. 300 Drill Seeder

This Planet Jr. product has extra substantial, wide tread wheels, front and rear, that run easier and cover more evenly than any machine you have ever seen. It involves new principles in seed dropping and the hopper is detachable, making it convenient for emptying seed. This machine is shaft driven, eliminating the annoyance of loose chains. The sowing device consists of plates with different size openings. We recommend it to anyone wanting a real substantial seeder for all soils and seeds. Capacity, 4 quarts. Price, $\$ 20.00$.

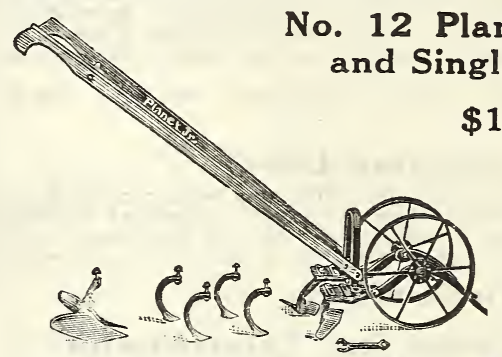
o. 12 Planet Jr. Double $\$ 10.75$

The Hoes are wonderful weed killers and lea level. Cultivator Teeth for deep or shallow work. Plows are valuable for opening furrows, covering or plowing to or from the crop. No. 13 Planet Jr.

No. 13 Planet Jr., double and single wheel hoe equipped with one pair 6-inch oil tempered hoes. Weight, $28 \mathrm{lbs}$. Price, \$8.00.

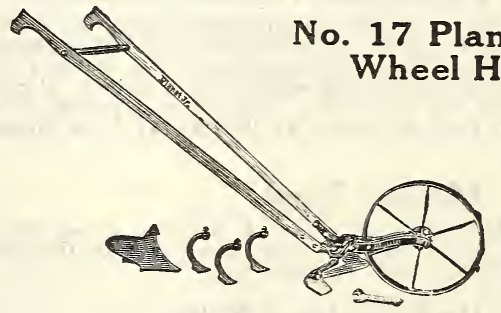

Weight, 33 lbs. 14 -inch Steel Wheels A Double and Single Wheel Hoe in one. inches high, then can be worked between the rows with 1 or whe rows.

ning say. High, easy rungive bigger, better crops. Lasts a lifetime.

No. 17 $1 / 2$ Planet Jr. Single Wheel Hoe

No. 171/2 Planet Jr. is equipped with one pair six-inch hoes, three cultivator teeth, oil tempered, and leaf lifter. Weight, 21 lbs. Price, cultivato.

No. 18 Planet Jr. Single Wheel Hoe

No. 18 Planet Jr. is equipped with one pair six-inch hoes only. Weight, 19 lbs. Price, \$5.75.

\section{Extras for Planet Jr. Hand Tools}

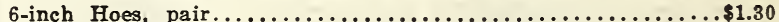

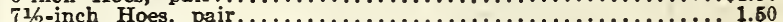

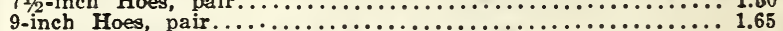

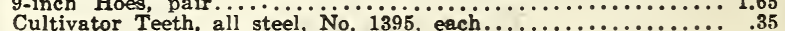
Plows for single whel Hoes, each

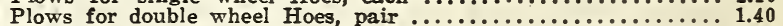

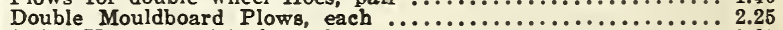

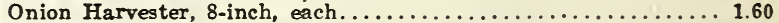

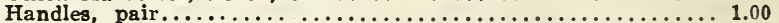

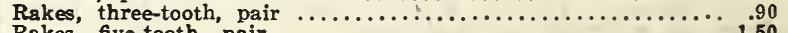

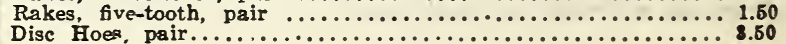




Buy and Plant warden Tools

\section{No. 119 Planet Jr. \\ Garden Plow and Cultivator, $\$ 4.50$ NOT PREPAID}

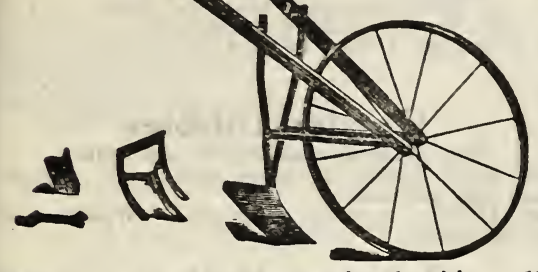

The No. 119 High Wheel Garden Plow and Cultivator is a very handy tool for the back yard garden. The 24-inch steel wheel makes it an easy running tool, especially if the ground is rough carefully prepared. It is equipped with a $11 / 4$-inch cultivating tooth, a 4-inch cultivating tooth, plow and reversible scuffle blade, all of which are useful and make gardening operations easier. Do not confuse the No. 119 Garden Plow and Cultivator with lower roel tools of this type. In every way it is up to priced high wheel tools of this type. In every way it is up to Planet Jr. quality and will give many years of satisfactory service.

\section{No. 4 Iron King Steel Frame Seeder} The Lettuce Seeder $\$ 16.00$

\section{NOT PREPAID}

The No. 4 Iron King Seeder is constructed of steel throughout. practically indepractically inde-
structible. It is very simple to operate and has fewer and less complicated parts seeder. This

seeder has a 15-inch front wheel and 13-inch rear wheel, each with $21 / 2$-inch tires. It is equipped with 2 seed plates, 1 regular iron agitator, 1 brush agitator for tender seeds. The hopper is easily removed making it a very simple matter to empty the seed can with out turning the seeder completely over. The V-shaped shoe makes it possible to sow all seeds in an exact line and at a uniform depth. This machine excels as a Lettuce Seed planter, but it will also son other seeds efficiently.

No. 53 Planet Jr. Two-Row Walking Cultivator, $\$ 52.50$, Denver

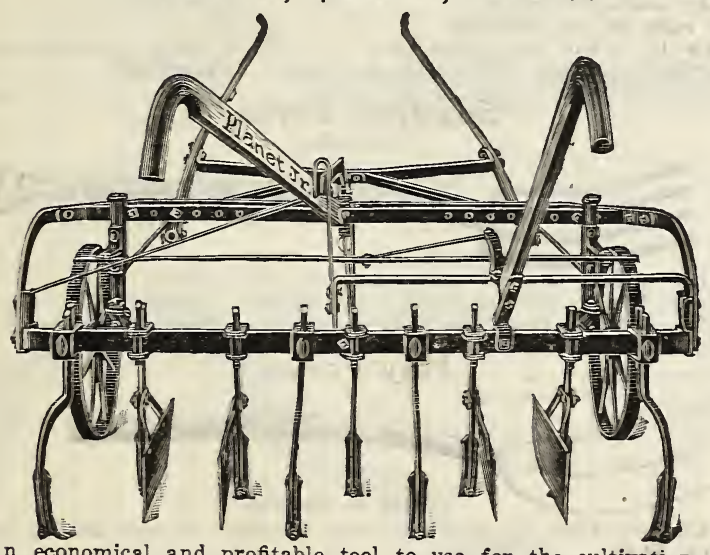

An economical and profitable tool to use for the cultivation of market garden crops, truck crops, sugar beets and beans. It is al steel except the handles and can be steered with ease by means of the pivot wheel and hand lever. Equipment: Two pairs 6-inch hoes standards. Packed weight, 246 lbs.

\section{No. 53D Planet Jr. Two-Row Walking} Cultivator, $\$ 46.50$, Denver

This is exactly the same tool as No. 53 but with less equipment. Two pairs 6 -inch hoes and standards; three 8 -inch improved sweeps. Packed weight, $227 \mathrm{lbs}$

For shallow work the equipment of No. 53D, hoes and sweeps, is sufficient but for deep work, the cultivator teeth, as supplied with

No. 3 Planet Jr. Four-Row Sugar Beet and Bean Horse Hoe and Cultivator. Complete .................... $\$ 125.00$ No. 3D. Same with hoeing attachments, only........... 95.00

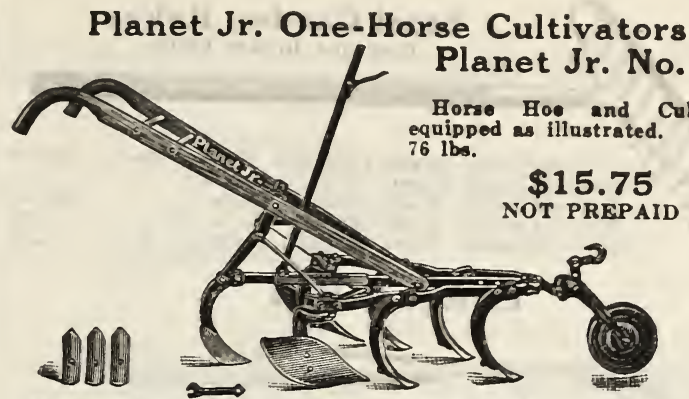

This tool has depth wheel and lever expander, turning shovels and shovel steel. The expanding lever slants backward between the han. dles, where it is well protected and cannot injure crops; no wires to stretch. The turning shovels are of special shape; useful in connection with the rear shovel in opening furrows and afterwards for covering them, and for plowing and hilling.

\section{Other Planet Jr. Horse Hoes and Cultivators NOT PREPAID}

No. 9-5-tooth Horse Hoe with steel wheel. Has plain wheel. No depth lever, adjustable to any reasonable depth and use-

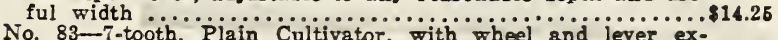
ponder tooth, Plain Cultivator, with wheel and lever ex- 14.25 No. $101-5$-tooth Plain Cultivator, with wheel and lever ex-

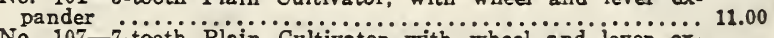
No. 107-7-tooth Plain Cultivator with wheel and lever ex.

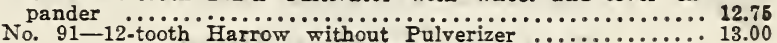

\section{No. 54 Iron King Twin Row Seeder}

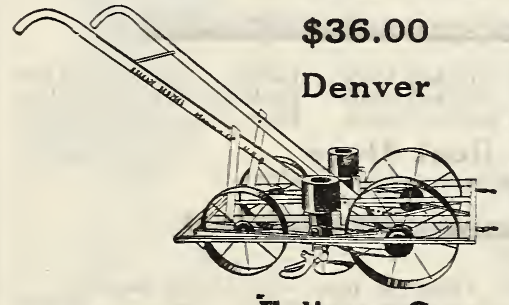

This two-row seeder. designed and built similar to the No. 4 Iron King single row seeder, may be run by hand or drawn by a horse, or attached to a cultivator. It works efficiently and is recommended unreservedly as a time and

Weight, 110 pounds.

Price, \$36.00 each,

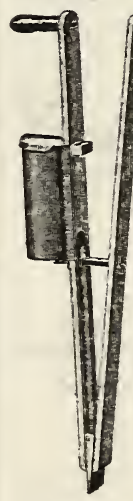

\section{Eclipse Corn}

Planter

This All-Steel Rotary Planter has given unequaled satisfaction for the past ten years. It has a positive feed and four changes of dises, and will sow Corn, Amber Cane, Kaffir, Sudan Grass, Milo Maize, Beans, Peas, etc. It is very simple Beans, Peas, etc. It is very will plant anything from cane to corn; and is arranged to drop one, two or three grains at a time as desired. Mailing weight $10 \mathrm{lbs}$ Price, $\$ 2.00$ each, not postpaid.

\section{Acme Corn}

\section{Planter}

Works in any soil; has a flexible and adjustable iron drop. Very simple in construction. It has an iron seed box and iron channel.

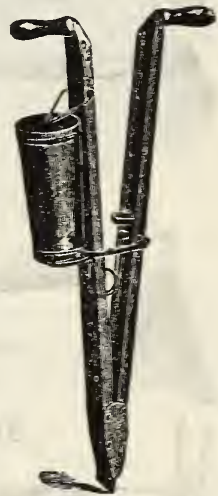

The foot is made of polished steel. It is well made, strong and will give complete satisfaction. Weight 7 lbs. Price, $\$ 1.25$ each, not prepaid.

Genuine Cahoon Broadcast Seeder The Cahoon Broadcast Seed Sower is a com pact, easily operated machine and is guaranteed to give satisfaction in every way if used according to instructions. It is so well constructed it will last a lifetime in any climate. The seed bag is made of The seed bag is made of
heavy duck and holds heavy duck and holds about 22 quarts. The control that regulates very simple and is easi- AND ly raised and lowered FRAM so that any amount per MALL sown. Mailing weight, 8 pounds.

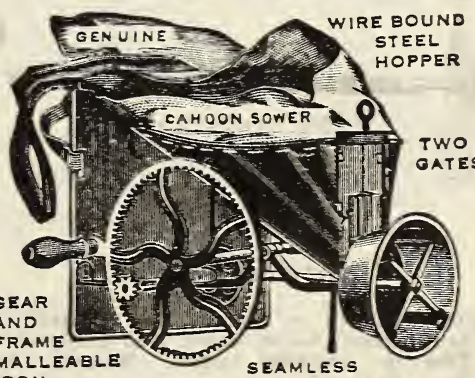

Price, $\$ 4.50$ esch, not postpaid 


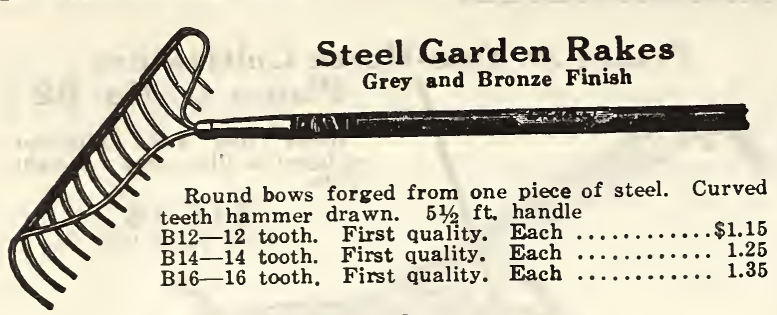

\section{Lettuce Cutters}

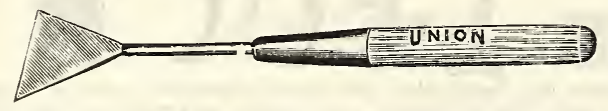

This tool was developed primarily to meet the demands of the This tool was developed primarily to meet the demands of the large lettuce growers for harvesting their crops. found very

Style LCD has offset shank, 8-inch handle, thirteen inches long over all, 3-inch blade. Price postpaid, each, \$1.00.

\section{Solid Socket Mortar Hoes} First Quality

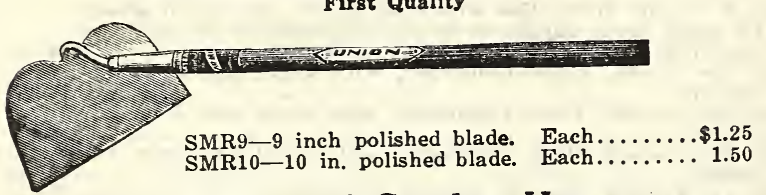

Field and Garden Hoes Solid Socket-First Quality

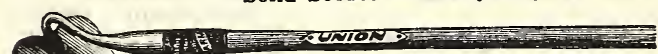

SG6-6 in. polished blade. Each.........\$1.00 SG6-6 in. polished blade. Each............... Each.......

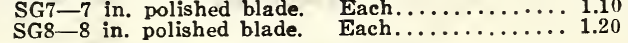
Beet Hoes

Solid Socket-First Quality

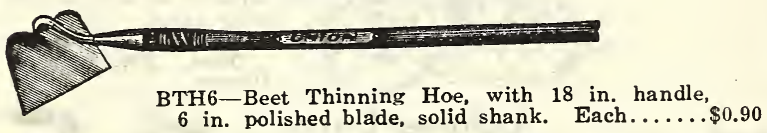

BTH6-Beet Thinning Hoe, with 18 in. handle,
6 in. polished blade, solid shank. Each......\$0.90
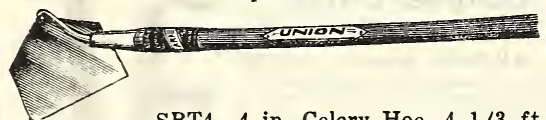

SBT4-4 in Celery Hoe $41 / 3 \mathrm{ft}$ handle Each SBT6-6 in. Nurseryman's Hoe, $41 / 3 \mathrm{ft}$. handle. 1.00 SBT7-7 in. Nurseryman's Hoe, $41 / 3 \mathrm{ft}$. handle. 1.10

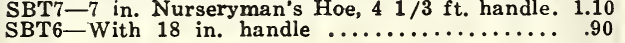

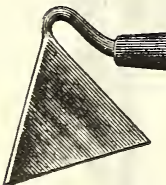

1

\section{Onion Weeder}

OW-3 in. steel blade, bronze finish, 8-in handle. Each ................ $\$ 0.60$

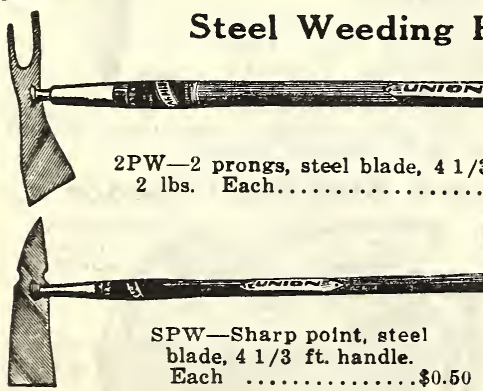

\section{Planters Eye Hoe}

SEOOO-Dutch or Potato Hoe. 6-inch half polished blade, Scovil field pattern. Fine for crushing lumps. Weight, 3 lbs. Each.................\$ $\$ .90$
Victory Garden Cultivator

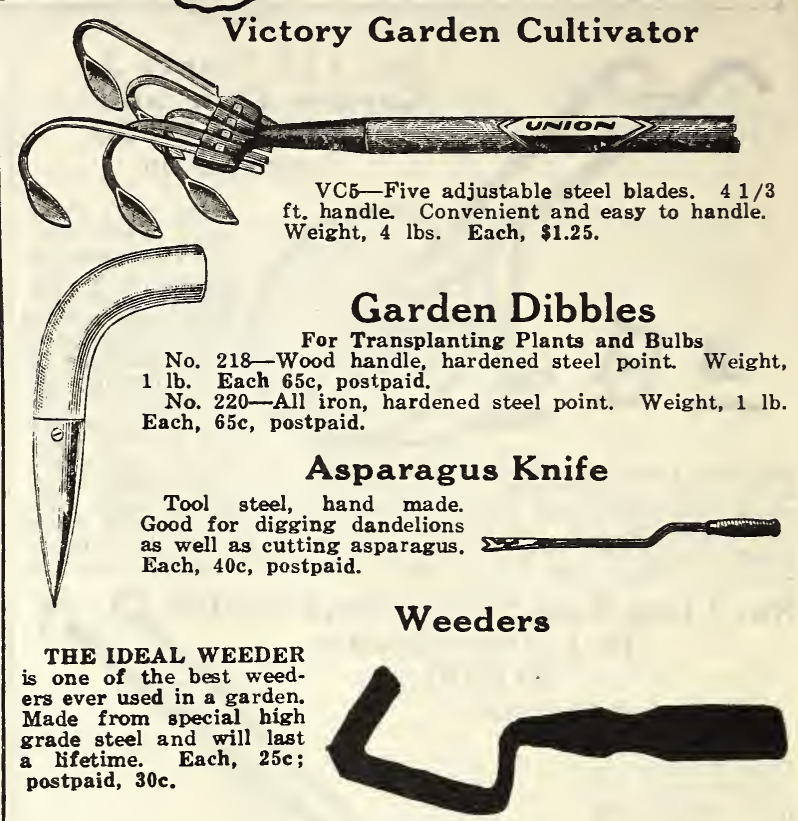

\section{Hand Weeder}

No. 87 Hand Weeder, made of one piece of hard, stiff steel. Ground edges and baked black enameled handle. Price, each, 20 c.

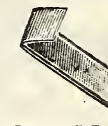

\section{Magic Weeder Hoes}

Popular, labor-saving, low priced cultivating devices.

Style A. Three galvanized tines. Width, 2 inch es; length, $91 / 4$ inches. es; length, $91 / 4$ inches.

paid.

Four galvanized tines.

Width, 3 inches; adjust-

able; length, 10 inches.

$35 \mathrm{c}$ each, or $45 \mathrm{c}$, postpaid.

Style G. Four galvanized tines. Width, 5 inches; adjustable ;

length, 57 inches. $\$ 1.00$ each, by express, not prepaid.

\section{Spading Forks}

D Handles

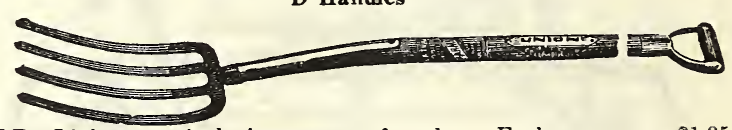

SALD-Light, polished tines, strap ferrules. Each........\$1.25 SAHD-Heavy, polished tines, strap ferules. Each......... 1.50 TSAW-Jumbo, extra heavy, strap ferrules. Each............

\section{Hay Forks}

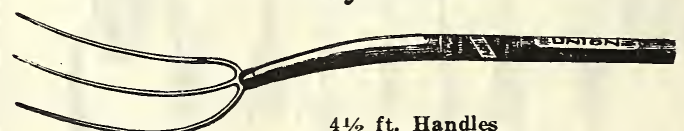

AS1341/2-Four 13-inch tines, strap ferrules. A good alfalfa fork. Each, $\$ 1.65$.

KS1541/2-Four 15-inch tines, deep dish, strap ferrules. Kansas header fork. Each, $\$ 2.00$.

\section{Manure Forks $41 / 2 \mathrm{ft}$. Handles}

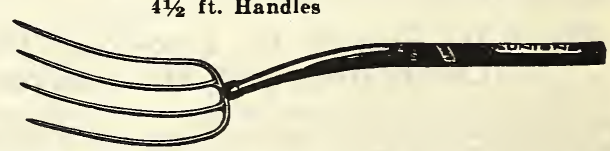

S441/2-Four polished tines, strap ferrules. Each..........\$1.65 S541/2 - Five polished tines, strap ferrules. Each................. S64 $1 / 2$-Six polished tines, strap ferrules. Each................. Irrigating Shovels 


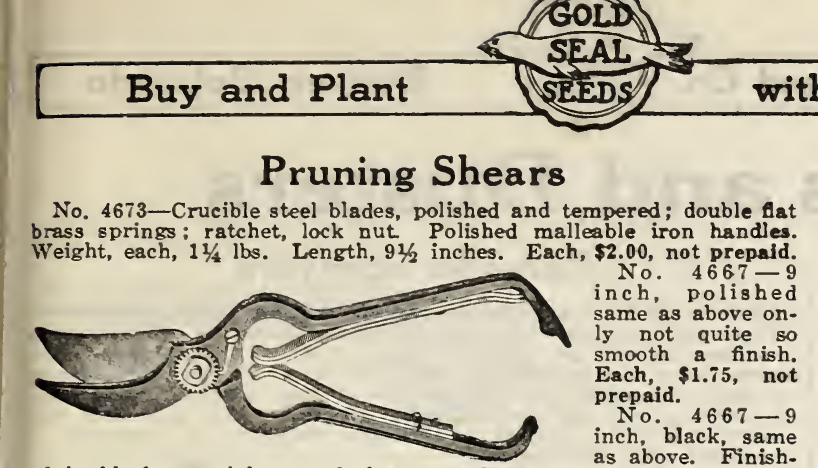

ed in black-a mighty good shear. Each, $\$ 1.15$, not prepaid.

\section{Long Handle Tree Pruners}

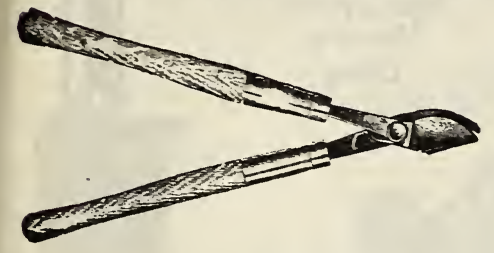

No. 2030-30-in. han dle, both sides drop forged from special al. loy steel, polished and tempered; $r$ in forced ferrules, polished; natbandles; lock nut. Each, $\$ 2.85$, not postpaid.

\section{Hedge Shears}

No. 101T-8 inch. Straight forged steel blades; notched. Each, 2.00 , not prepaid.

No. 101T-9-inch Blades. Each, \$2.25, not prepaid.

\section{Lettuce Trimming Knife}

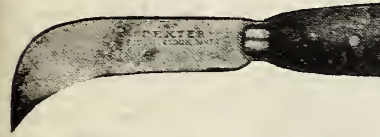

This is the style

light, strong, and durable. Each, 50c.

\section{Solid Steel Garden Tools}

Are made of heavy pressed steel, with blade and handle all in one piece, and fitted with

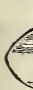

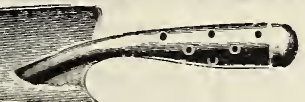
smooth steel cap on the end of the handle, affording an easy grip

No. 120-Garden Trowel. 6-inch blade. Each, 25c, postpaid.

No. 520-Transplant-

ing Trowel and Weed

6 in. long. Each, $25 \mathrm{c}$

postpaid.
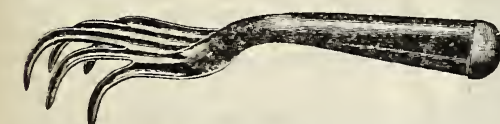
No. 620-Steel Gar. claws. For weeding and mulching. Length, $91 / 2$ in. Each, 25 c, postpaid.

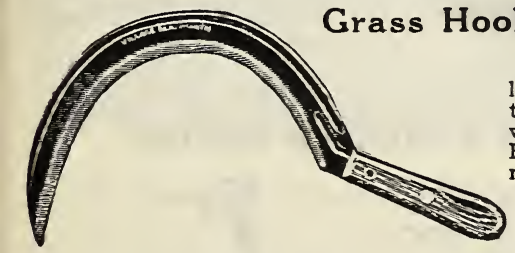

No. 4-Grass Hook, cutlery steel: corrugated, tempered blade; ground wide, thin and sharp. Riveted handle. Price, not postpaid, each, 55c.

No. $450-$ Grass Hook, with patented offset, swings perfectly in the hand with little muscular effort. Forged cutlery steel, tempered, forged wide, ground with a long bevel, sharp, and whetted. a long bevel, sharp, and whetted.
Price, not postpaid, each, $\$ 1.00$.

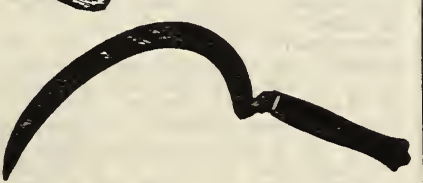

Grass Shears

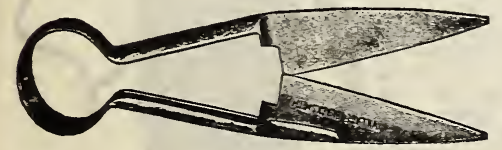

No. $380-51 / 2-$ in. half polished blades: polished shanks. Price, not postpaid, each, $50 \mathrm{c}$. No.
style as No. 380 , with style as No. 380 , with
red en a meled bow, red en a meled bow, not prepaid, each, 75c.

\section{Grasnips}

No. 1927-Handles offset leaving elearance for hand and blades flat or parallel to ground. Price, not postpald, each, $\$ 1.00$.

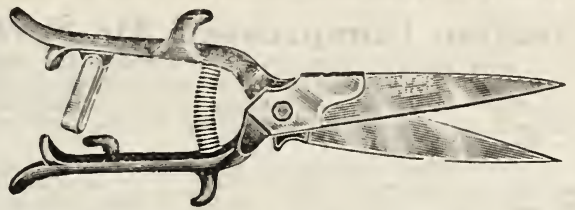

Cyclone Seed Sower

The Cyclone Sower is suaranteed to distribute seed perfectly. and will not throw seed in 8 , and will not throw seed in an operator, but direct and evenly to the land. Sows clover, tim. othy, red top, alfalfa, oats, rye, wheat, millet, buckwheat, turnip and other varieties of farm seeds. Clover seed is sown at a width of 18 feet; timothy, 15 feet; alfalfa, 20 feet; wheat, 25 feet; millet, 18 feet; oats, 18 feet.

Price, $\$ 2.25$ each, postpaid. $\$ 2.00$ each, not postpaid.

\section{Blackhawk}

Grist Mill
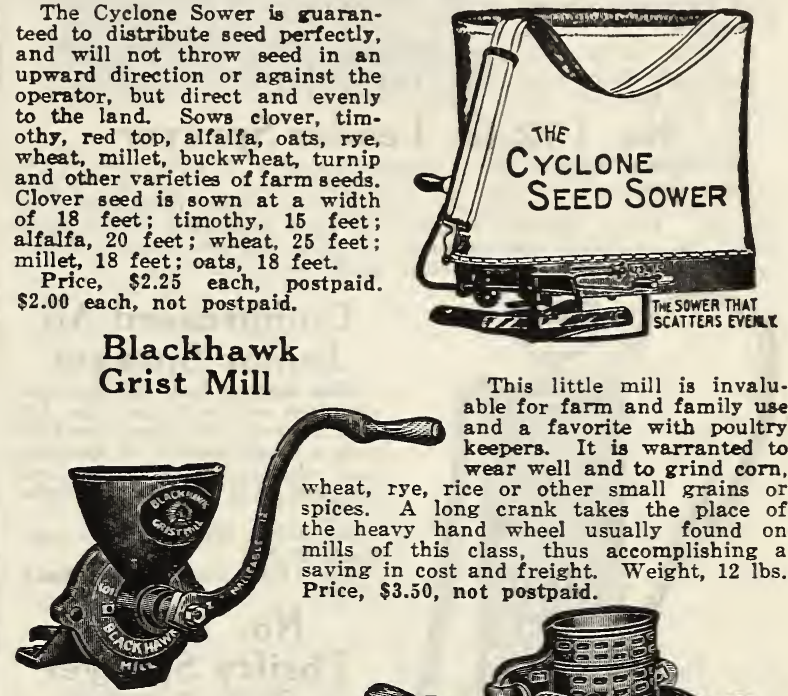

Blackhawk

Corn Sheller

This is a substantially made tool, easy to run a boy can shell a large quantity a day with this machine. We have never known one to get out of orderwill last a lifetime. Mailing weight, $12 \mathrm{lbs}$. Price, $\$ 3.25$ each, not postpaid.

\section{Steel Sacking Needles}

This little mill is invalu. able for farm and family use and a favorite with poultry keepers. It is warranted to wear well and to grind corn, weat, Iye, rice or other small grains or pices. A long crank takes the place of he heavy hand wheel usually found on saving in cost and freight. Weight, $12 \mathrm{lbs}$ Price, $\$ 3.50$, not postpaid.

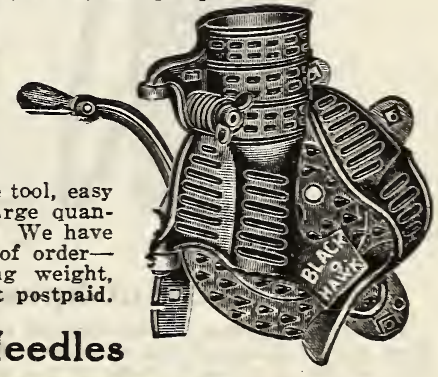

Not postpaid unless included with other goods.

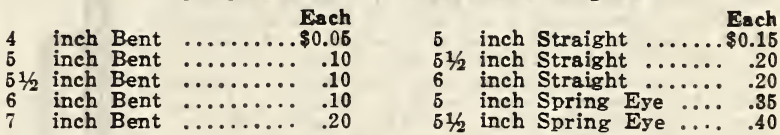

\section{Twine for Sacking and Tying}

$21 / 2$ oz balls, 4 ply white Cotton Erch ................. \$0.10

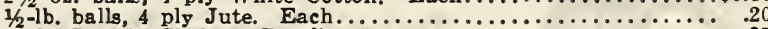
4 ply Jute in Skeins. Per lb ....................................... 4 ply Flax in Skeins. Per lb. 16 ply Cotton in Skeins. Per lib.

Not postpaid unless included with sufficient other goods.

Jute Twine for tying Celery and Bunch Vegetables, in 1/2-1b., 3-lb. and 5 -lb. Balls. $30 \mathrm{c}$ per $1 \mathrm{~b}$.

Celery Tape. No. 17, Fast Blue or Red, for tying Celery for market, 1000-yard spools. Each, $\$ 2.25$.

\section{Traps}

Catch the mice and rats and prevent loss.

Victor Mouse Traps. Three for $10 \mathrm{c}$.

Victor Rat Traps. Each, 20c.

Not prepaid unless included with other goods.

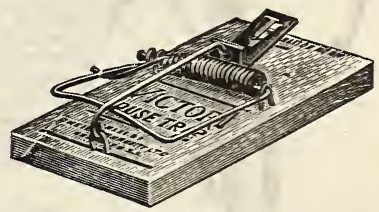

Galvanized Watering Pots

Or sprinkling cans. Very convenient for hotbed use.

No. $616-6$ quart. Each not postpaid...................\$ \$0.85

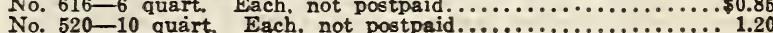

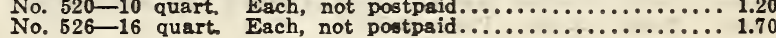




\section{Spray Pumps and Dusters}

\section{Perfection Compressed Air Sprayer}

This is a high pressure compressed air sprayer for any and all work. It is particularly adapted for spraying potatoes and garden work. It is particularly adapted for spraying potatoes and garden whitewash, cold-water paints, disinfectants, de-odorizers, insecticides, whitewash, cold-water paint
stock dips, floor oils, etc.

stock dips, floor oils, etc.
Tank is heavy gauge galvanized sheet or all brass as ordered. All seams are riveted and soldered. Pump is of seamless brass tubing which seals into the tank by a simple twisting device controlled by a turn of the $D$ handle. It is easily removed for filling, cleaning, etc. Hose is special spray hose for high pressure. Equipped if desired.

Capacity, about 4 gallons. Shipning weight, 11 pounds.

No. $110 \mathrm{G}-$ Galvanized tank. Price, each, $\$ 6.50$.

No. 110-B-Brass tank. Price, each, \$9.50.

No. 192-G Leader Sprayer

The Leader Sprayer has a galvanized tank of first quality galvanized sheet and contains $33-4$ gallons. It is a very low priced, high pressure compressed air sprayer extensively used for every purpose. Pump seamless brass. All brass automatic nozzle fitted ing eleven pounds. Price, not prepaid, each, $\$ 4.25$.

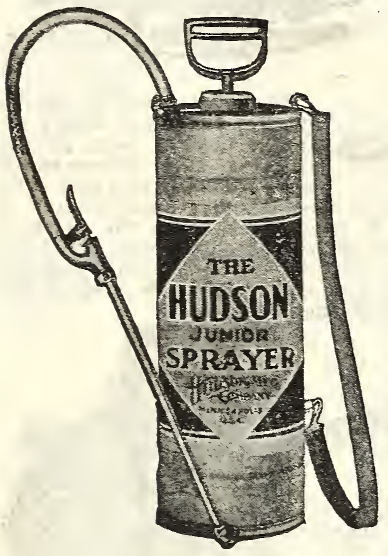

Compressed Air Junior Sprayer

This sprayer has the same construction as the larger one, but it is designed for those who have only a small amount of spraying and who desire a lighter load. Capacity, $2 \frac{1}{2}$ gallons. Weight. 8 lbs.

No. $140 \mathrm{G}-\mathrm{Galvanized} \mathrm{tank.}$ Each, $\$ 5.00$.

No. $140 \mathrm{~B}$-Brass tank. Each \$7.75.

No. 120-G

Thrifty Sprayer

The Thrifty Sprayer has a capacity of two gallons with a screw top pump. It is a very serviceable sprayer and most convenient for those having a limited use for a compressed air sprayer. Price, not prepaid,

\section{Little Giant Sprayer}

These spray pumps are constructed entirely of brass. They are so arranged that the labor of pumping is all done on the downward stroke of the piston and nothing on the up. The effect of this operation while pumping is to hold the pump down. The foot rest steadies the pump, holding it in proper position. They are provided with large air chambers, and have brass ball valves and detachable hose; the nozzle throws a continuous spray, and is not affected by the movement of the plunger. Will carry a pressure on the nozzle of from 50 to $100 \mathrm{lbs}$. with very ordinary exertion. Will throw a stream fifty feet, and are of unusual value for spraying trees, washing windows and bug. ries, extinguishing fires, sprinkling law and buggies, extinguishing fires, sprinkling lawns, flo
Weight, 6 lbs. Price, $\$ 4.00$ each, not postpaid.

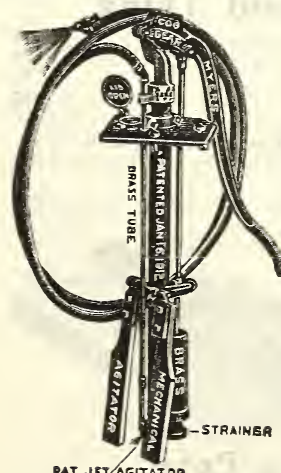

Cog Gear

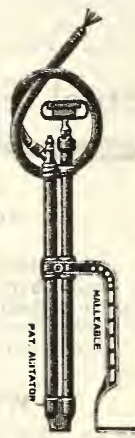

\section{Barrel Spray Pump}

The construction is such that the entire pump rets inside the barrel containing the liquid, being bolted fast at its upper end to the head of the barrel. By this arrangement the working parts are entirely submerged in the liquid that is to be sprayed, thereby avoiding all possibilities of losing priming, doing away with the necessity of a suction pipe, placing the agitator in the bottom of the liquid in a simple form, and also doing away with a large amount of complicated parts. Base fits $8 \times 8$ inch hole Weight, $40 \mathrm{lbs}$. Price, complete with 15 feet hose and nozzle, $\$ 15.00$.

\section{Crank Driven Duster}

We otter a Lrank Driven Powder Duster that can be used with on or two nozzles. Will handle any powder to an accurate gauge. Growers with extensive acreage will find this a very efficient machine. Weight, 22 lbs. Price, $\$ 15.00$.

\section{Paragon Sprayers}

This is the only machine on the market that works satisfactorily for several purposes. It is positively a first-class white-washing machine, as well as a tree spraying machine. The spray nozzle cannot clog, no matter how dirty the liquid, as the liquid passes through the automatic self-strainer before entering the pump. A heavy, steady pressure is easily obtained. This is a very well constructed and a lasting and durable machine. A guarantee is furnished with every one.

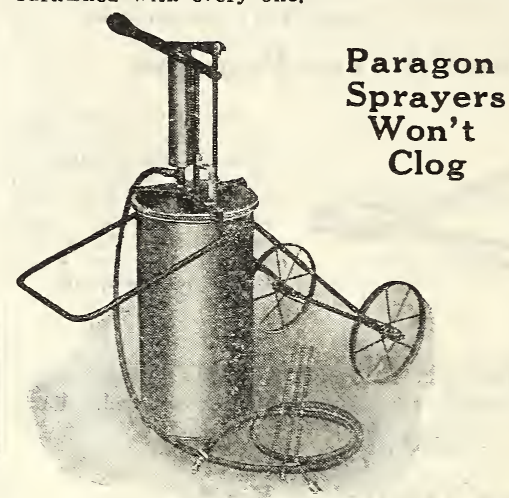

Paragon No. 3

Twelve-gallon. Equipment, $71 / 2$ feet extension pipe, 10 feet 6 -ply hose, 2 spraying nozzles. This machine is mounted on a strong steel frame, and can easily be wheeled to any desired place. Price, $\$ 25.00$.
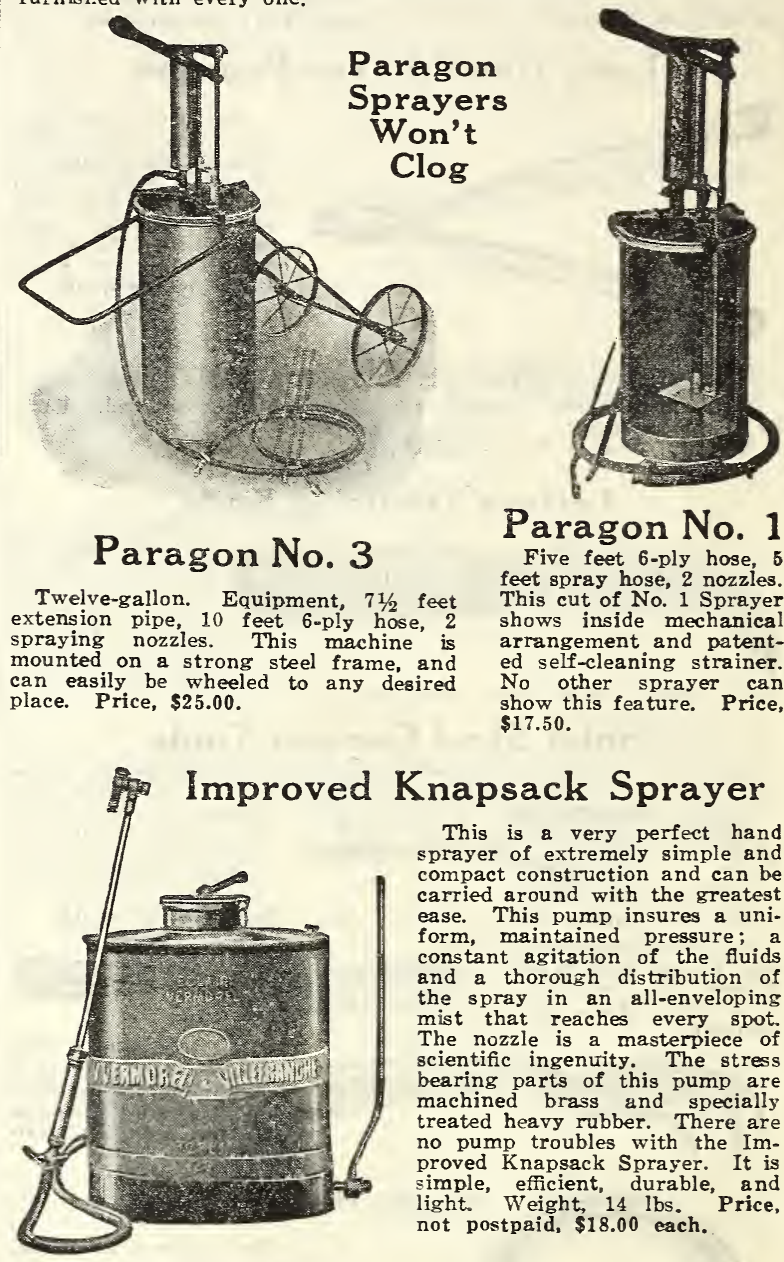

Paragon No. 1

Five feet 6-ply hose, 5 feet spray hose, 2 nozzles. This cut of No. 1 Sprayer shows inside mechanical arrangement and patented self-cleaning strainer. No other sprayer can show this feature. Price,
$\$ 17.50$.

\section{Improved Knapsack Duster}

This Powder Duster is an efficient companion for the Improved Knapsack Sprayer. This type is commonly called a "puffer" as the flow is intermittent, not constant, but for general use it is the most servicegeneral use it is the most serviceable. It will dust Sulphur, Arsenate of Lead, Paris Green, Bordeaux Powder, Lime, Tobacco or Nicotine lbs. (shipping weight, 17 lbs.), and is carried on the back, as a knapsack, with ease. A light stroke of the lever insures an even flow of material with sufficient force for thorough penetration. Equipped with fine and coarse screens and adjusting slide to regulate volume of flow. The Improved Knapsack Dustter is of the bellows type, and has no cogs, wheels, belts or other complicated mechanism that would be likely to wear and give trouble. Price, not postpaid, $\$ 15.00$ each.

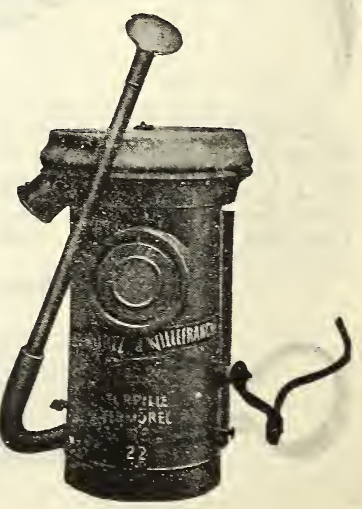




Buy and Plant NEEDS with Confidence

\section{Hand Sprayers and Dusters}

The hand sprayers shown below are very useful in small gardens, for spraying house plants, poultry houses, etc., and applying liquids for a fine mist with no waste.

\section{1}

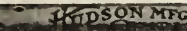

Capacity, 1 Quart.
Misty Sprayer

A universal favorite with the largest sale to its credit of any similar type sprayer. Note its s t u r d y appearance
and construction by which we combine nt of the pump passes through the tank and is firmly soldered. Spras tube is aligned
before soldering so that the air and syphon tubes are always in line. through the tank and is firmly soldered. Spras tube is aligned
before soldering so that the air and syphon tubes are always in line. Every sprayer carefully inspected and tested before packing. Weight. 116 lbs. Price, not postpaid, with tin tank, 50c.

MIDGET SPRAYER. Same construction as the Misty. Tin tank. 1 pint capacity. Each, not postpaid, 35c.

\section{Continuous}

Hand

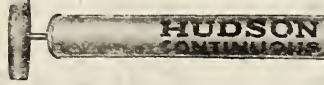

Sprayer

Capacity, 1 Quart.

\section{Higher Prices for Your Crops}

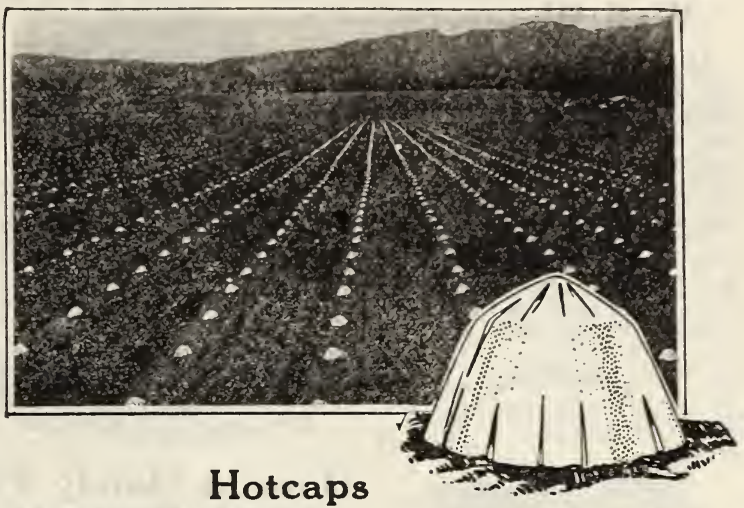

This Amazing New Method of Plant Protection gets rou Higher Prices for Larger and Quicker Crops.

Thousands of growers have added to the value of their vine crops by using Germaco HOTKAPS-shown above. This remark able invention consists of a scientifically constructed wax paper cone that you place over each plant. Thus they are miniature hothouses that protect plants from frost, wind, rain, insects and ground crusting.

HOTKAPS not only protect plants, but make them grow hardier and faster. Thus you get a greater crop production to market earlier for higher prices!

One man can "set" 3000 Hotkaps per day. They not only bring you higher prices, but are a method of crop insurance-against the danger of the elements.

Prices: 1,000 lots, $\$ 11.50 ; 5,000$ lots, $\$ 11.00 ; 10,000$ lots, $\$ 10.75$ 250 trial package, including special type garden setter, $\$ 4.00$ Germaco steel HOTKAP setter, \$2.50.

If you need HOTKAPS for your back yard garden, note these prices: 50 with special setter, $\$ 1.50 ; 100$ with garden setter, $\$ 2.25$ garden setter alone, 50 cents.

\section{Transplanting Plant Bands}

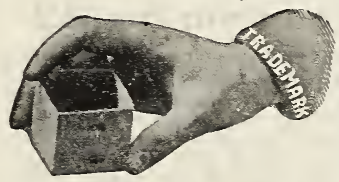

The simplest way to handle plants for transplanting is to grow them in our Ready-to-use Plant Bands, because they are ready to use and no time is lost in setting them up. You will find these bands very economical; they these bands very economical; they
make an ideal worm guard. When make an ideal worm guard. When transplanting the old way the roots that the plants are seriously set back. With Plant Bands it is even possible to transplant corn and cucumbers. Plants started in these bands and set in the field never know they have been moved.

Prices on these bands with folding bottoms; prepaid if included with sufficient other goods. Doz. $100 \quad 250 \quad 1000$

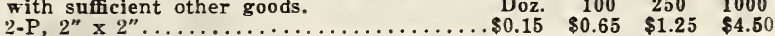

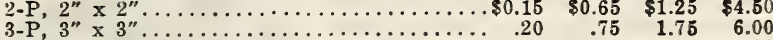
$3-\mathrm{P}, 3$
$4-\mathrm{P}, \mathrm{x}$

Order these with your seeds. Start the seeds early indoors in flats or boxes, transplant single plants into these bands and when the weather is settled set the plant in the garden without removing the band. Growth is not retarded and the plant is further advanced.

\section{Auto Display and Feeding Coop}

This new coop is of the same durable construction as the shipping coop shown below. It is made of the best galvanized wire permanently welded at each joint. There are two sections with roomy doors opening to each. The floors are strong and easily removed for cleaning. It is the most sanitary coop on the market. It is 41 inches high and 13 inches wide, weighs $19 \mathrm{lbs}$. and can be easily attached to the running board of any automobile, replacing the unsightly, unsanitary makeshift coop that protrudes beyond the car and is a menace to traffic. It is also excellent for display and feeding purposes, or when not on the auto for general use about the poultry yard. Price, not prepaid, $\$ 2.75$ each

\section{Wire Shipping Coop}

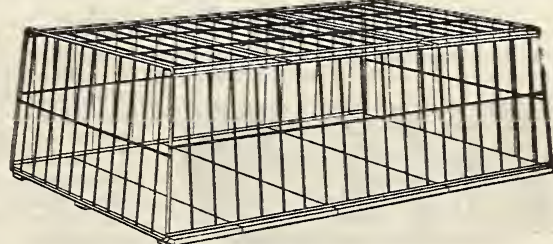

This shipping coop is, as illustrated, strongly built of galvanized wire and is electrically welded at each joint. It is 41 inches long, 13 inches high and 27 inches wide. The floor is easily removed. The door in the top can be securely fastened, very quickly. Every poultry shipper should have one.

\section{A very handy small} duster that handles all making it very valuable around the home hotels and public build. ings ; in the home gar-
den and truck plots. Shipping weight 2 lbs. Price, not postpaid, $\$ 1.25$ each.
Price, not postpaid, $\$ 2.75$ each. 


\section{Hudson Double Wall Waterer}

This double wall waterer is top filled. Double wall keeps water cool in Summer and retards freezing in Winter. Operates on vacuum principle. Feeds automatic. Small gutomatic valve prevents pan overflowing while being filled. Two sizes. while being filled. Two sizes. lon. One in carton. Shipping weight 12 lbs. $\$ 3.00$ each. No. CW8. WATERER. $8 \mathrm{gal}$ lon. One in carton. Shipping weight 14 lbs. $\$ 4.50$ each.
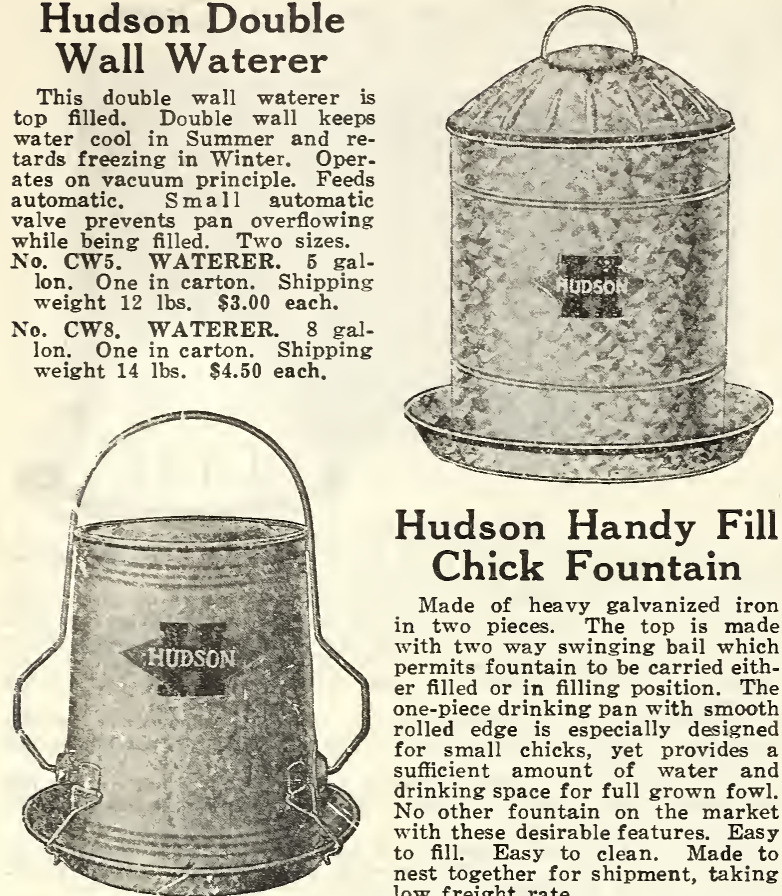

Made of heavy galvanized iron n two pieces. The top is made with two way swinging bail which permits fountain to be carried either filled or in filling position. The one-piece drinking pan with smooth rolled edge is especially designed for small chicks, yet provides a sufficient amount of water and drinking space for full grown fowl. No other fountain on the market with these desirable features. Easy to fill. Easy to clean. Made to nest together for shipment, taking low freight rate.

No. CW2. Two-Gallon Chick FOUNTAIN. Four in carton. Shipping weight, 15 lbs. $\$ 1.20$ each.

No. CW3. Three-Galion Chick FOUNTAIN. Four in carton. Shipping weight, 19 lbs. $\$ 1.50$ each.

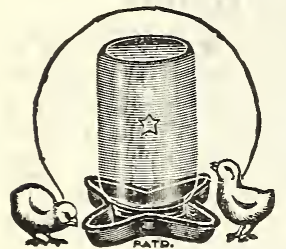

Star Fountain No. 32

The Star Fountain is made of a single piece of heavy non-rusting metal without seams, solder or loose parts. It cannot seams, solder or loose parts. It can be used for feed as well as water. Made be used for feed as well as water. Made in one size only which will fit any Mason each, $10 \mathrm{c}$; doz., $\$ 1.00$, postpaid.

\section{Round Jar Fountain}

The Round Jar Fountain is made in extra heavy galvanized iron and enamel without the use of solder. There Jar. We do not furnish the jars. This is a very sanitary fountain. It is well made and will last indefinitely. Price, Galvanized, each, 10c; doz., \$1.15; Enamel, each, 10c; doz., \$1.30, postpaid.

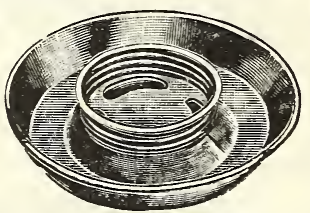

Round Baby Chick Feeders

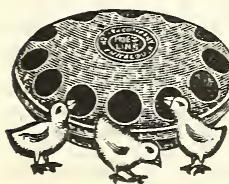

These feeders are very popular as the chicks cannot upset them and they keep the feed clean and sanitary. The top fits snugly but can be gasily removed for cleaning and filling. They well made from the best quality tight water or milk as well as mashes and grain feed. Made in two sizes.

Prices, not postpaid: No.

Same style feeders made Same style feeders made of bright charcoal tin for feeding butter-

\section{Eclipse Feed Troughs}

This is a fine popular priced feeding trough made of galvanized iron and intended for chicks and growing stock. The pan and top

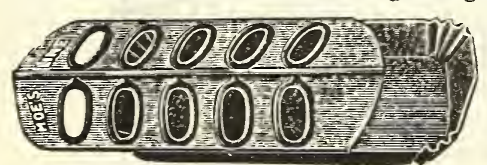

No. 27-10 in. long, 10 holes, each

No. $28-20$ in. long, 20 holes, each

Same style feeders made of milk.

No. $137-10$ in. long, 10 holes, each

No. $138-20$ in. long, 20 holes, each

\section{Long Chick Feeders}

Made of heavy galvanized steel, with sliding top cover, easy to clean and refill. A great time and labor saver.

No. 140-Capacity, 10 quarts. Feeds 32 chicks at a time. Each $\$ 1.30$ No. 141-Capacity, 17 quarts. Feeds 54 chicks at a time. Each. 1.95

\section{Cone Top Bottom Fill Fountains}

This popular, low-priced water fountain is made in two pieces, accurately stamped and formed from the best quality galvanized from in three sizest It is easily filled and easily cleaned. The round taper shaped top prevents bursting from freezing and keeps the fowls from roosting on it.

No. $19-1$ qt., 6 in. high. Each.....\$0.25 No. 24-1 gal., 91/2 in. high, Each $\ldots$.35
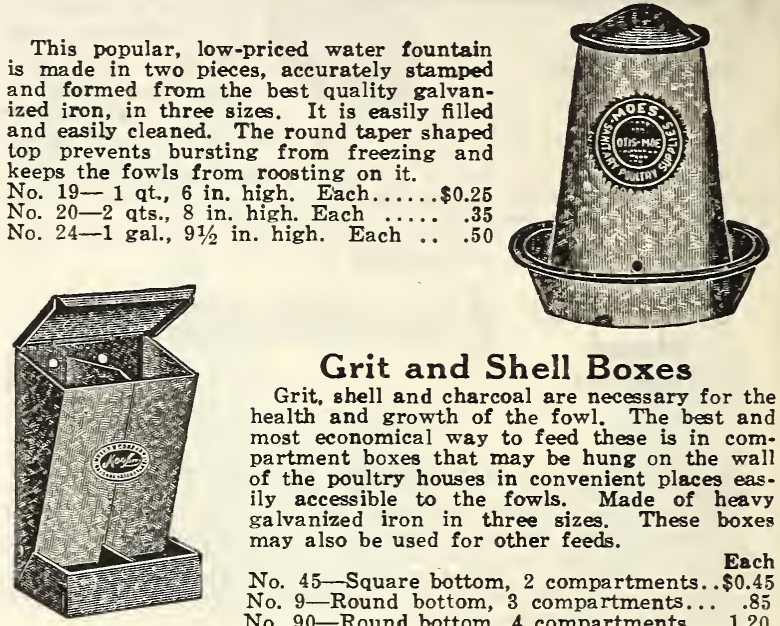

\section{Grit and Shell Boxes}

Grit, shell and charcoal are necessary for the health and growth of the fowl. The best and most economical way to feed these is in compartment boxes that may be hung on the wall of the poultry houses in convenient places easily accessible to the fowls. Made of heavy galvanized iron in three sizes. These boxes may also be used for other feeds.

No 15 No. 45-Square bottom, 2 compartments.. \$0.45 No. 90-Round bottom, 4 compartments... 1.20

Thermometers and Hygrometers

No. 5774-Tycos, angle pattern, flange on upper edge turned over to hook on wire or metal strip, four inch scale. Each, postpaid, 75c. No. 5783-Tycos Certified, angle pattern, four inch black oxidized brass scale; every fifth line and figure stamped on scale and white filled and every single degree engraved on mercury filled tube. Each, with certificate, postpaid, $\$ 1.15$.

No. 5981-Tycos Soil (Hotbed) Thermometer. 15-inch V-shaped wood case with handle, strong pointed metal end. Each, not postpaid, $\$ 2.50$.

No. 5796-Tycos Incubator Hygrometer, 33/4 inches high and $41 / 2$ inches wide over all. Prevents loss of millions of chicks by indicating the percentage of moisture. Complete with bowl, wick and thermometer, each, postpaid, $\$ 1.65$.

\section{Glass Nest Eggs}

These are a very close imitation of a real egg, both in shape and color. They are durable and not easily broken. 3 for $10 \mathrm{c}$; per doz., $40 \mathrm{c}$, postpaid.

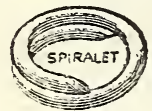

\section{Spiralet Celluloid Leg Bands}

Ten showy colors permit different flocks to be readily No. 5-Pigeon dentified. Very light and durable.

No. 4-Day O

8-Mediterranic

No. 11-American

No. 14-Turkey

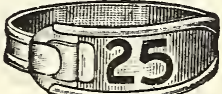

Adjustable Leg Bands Made of pliable aluminum. 12 for $15 \mathrm{c} ; 25$ Made of pliable alum
for $25 \mathrm{c} ; 100$ for $75 \mathrm{c}$.

\section{Farmer's Friend Egg Carrier}

This is a strongly built, light weight Egg Carrier, that holds 12 dozen eggs. But the patent adjustable cover makes it possible to carry one dozen just as safely as 12. The farmer and poultry man will find it very serviceable. Weight, $8 \mathrm{lbs}$. Price, not postpaid, each, $\$ 1.15$; six dozen size, each, $\$ 1.00$.

\section{Egg Cartons \\ These are convenient for} one piece, no seams, rivets or solder used. The sliding top makes keep clean. two sizes. Prices, not postpaid. They are one thickness of pasteboard with light weight fillers. Both are one dozen egg size. $\begin{array}{crrr}12.25 & \$ 2.25 & \$ 8.50 \\ \ldots 0.20 & \$ 1.25 & \$ .50 & 16.00\end{array}$ Poultrymen requiring larger feeders and waterers and those who buy in large amounts may find it to their advantage to advise us of their particular needs. 
 \\ Stock and Poultry Feeds}

\section{Blatchiord's}

Blatchford's Chick Mash

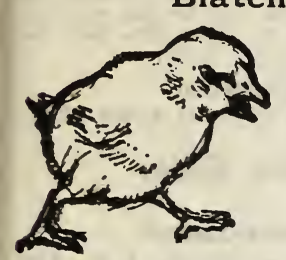

Blatchford's Chick Mash is the favored starting and growing feed of the most prominent poultry raisers in the country. It contains all the feeds and nutrimen chicks need right from the start. It shields them from white diarrhea bowel trouble and leg weakness.

This mash is

neither a tonic

nor a medicine,

but a nutritious, atable body-builder. It promotes health. vitality and growth by building up sturdy disease-resistant frames. It does not force, but by supplying proper nourishment to each and every part of the body. it promotes steady and complete development in the shortest possible time.

Blatchford's Chick Mash contains no screenings, hulls or cheap by-products from the manufacture of breakfast foods, cereal foods or scratch grains. It carries chicks all the way-starts, grows and matures-without change of rations, or Blatchford's Growing Mash may be substituted at the end of 4 or 6 weeks. $10-1 b$. bag, 70c; 25-lb. bag, $\$ 1.35 ; 100$-lb. bag. $\$ 4.95$, not prepaid.

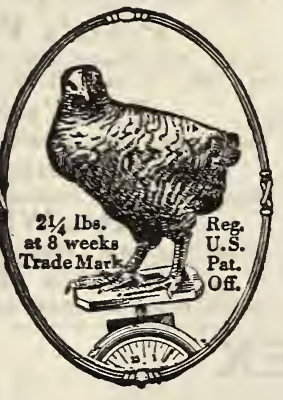

\section{Blatchford's Growing Mash}

Price, 25 lbs., \$1.25; 100 lbs., \$4.00.

\section{Blatchford's Calf Meal}

Blatchford's Calf Meal is the original Milk-Substitute. It was the first on the market. For over one-third of a century it has been successfully used in raising calves by the most progressive farmers and dairymen in this country. It is the only calf meal backed by so remarkable a record.

Its success is due to three things. FIRST, its quality. Blatchford's is above all a quality calf meal. Only the best materials are used in its manufacture. It contains no waste materials or by-products of low feeding value. SEC-
OND, it contains all the nutritive and
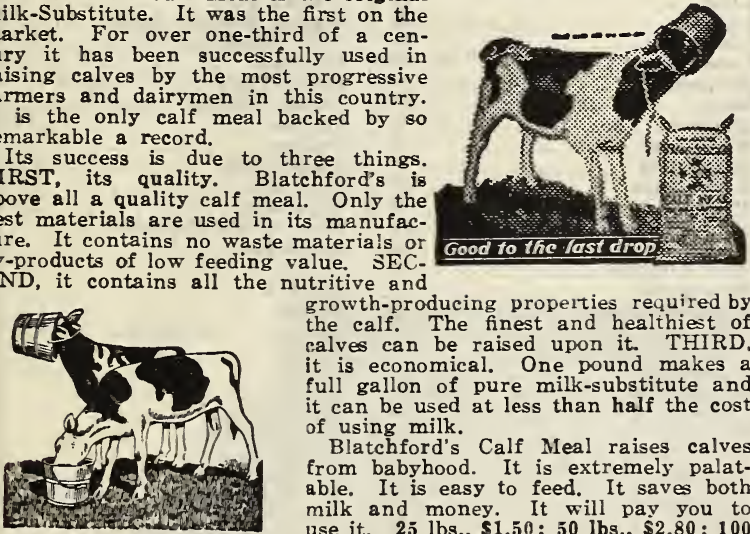
growth-producing properties required by the finest and healthiest of it is economical. One pound makes a full gallon of pure milk-substitute and it can be used at less than half the cost it can be used

Beal raises calves from babyhood. It is extremely palatable. It is easy to feed. It saves both milk and money. It will pay you to
use it. 25 lbs., $\$ 1.50 ; 50$ lbs., $\$ 2.80: 100$ lbs.. \$5.50, not prepaid.

Blatchford's Egg Mash

Blatchford's "Fill-the-Basket" Egg Mash is

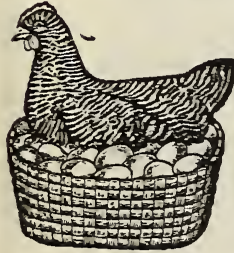
built upon the principle that eggs are manufactured from the feed the hen receives. In other words, the hen is an egg-making factory. Her feed is the raw material from which she makes her eggs. Consequently, her feed must makes her eggs. Consequently, her feed must be rich in materials required for egg-production. Scratch grains alone are not sufficient. nourishment is absolutely necessary if she is to yield her maximum of eggs.

Blatchford's Egg Mash contains a large va-

TRADE.MARK riety of the best materials available for egg manufacture. It successfully solves the probem of securing eggs both Winter and Summer. Feed it-you will find it a profitable thing to do. Every bag guaranteed to give satis-

Price, 25 lbs., $\$ 1.25 ; 100$ lbs., \$3.85, not prepaid.

Blatchford's Lamb Meal

Price, 25 lbs., $\$ 1.50$; 50 lbs., $\$ 2.80$.

$$
\text { Blatchford's Pig Meal }
$$

Price, 25 lbs., $\$ 1.50$; 50 lbs., $\$ 2.75$.

\section{Kow-Kare}

and Cheapest Insurance on the Health of Your Cows

KOW-KARE has been used for a longer period of time and by a larger number of dairymen than any other remedy with which we are familiar This can mean but one thing-KOW. KARE is a trusted preparation. Not only is KOW-KARE as near to an infallible remedy as can be, but it is withit but what is comforting and curative Recommended for Scouring, Lost Appetite, Bunches for Scouring, Lost Appethreatened Abortion, for Barrenness, for Retained Afterbirth and Milk Fever. Large size, $\$ 1.25$; medium size, $65 \mathrm{c}$; si large cans, $\$ 6.25$.
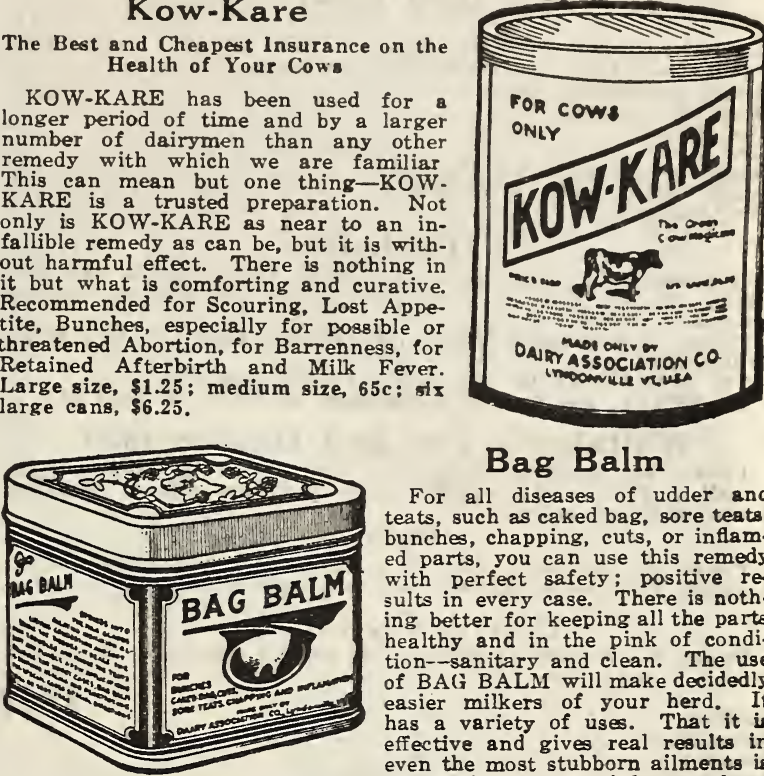

Bag Balm

For all diseases of udder and teats, such as caked bag, sore teats bunches, chapping, cuts, or inflam ed parts, you can use this remedy with perfect safety; positive re sults in every case. There is nothing better for keeping all the parts healthy and in the pink of condition--sanitary and clean. The use of BAG BALM will make decidedly easier milkers of your herd. It has a variety of uses. That it is effective and gives real results in even the most stubborn ailments is proved by scores of letters from those who have used it. Insist on $\mathrm{Bag} \mathrm{Balm}$ manufactured by The Dairy Association. Price, $60 \mathrm{c}$.

\section{Grange Garget Remedy}

Manufactured by The Dairy Association, for that serious disorder peculiar to cows, and which is a disease by itself. Grange Garget Remedy goes scientifically to the seat of the trouble. Can, 65c.

More Milk From the Cows You Have A valuable book, furnished free.

\section{Gold Seal Baby Chick Feed}

HOYT'S MIXTURE. A wholesome, ready prepared starting feed which will nourish the chicks so they can make rapid growth. Contains the necessary materials to form bone and feathers, such as seeds, millet, and grains. It gives the chicks quick growth and tends to keep them in good health. To properly develop the chick. either for market or to become a producer of eggs it must be fed such feed as will promote growth quickly and uniformly. 5 lbs., $25 \mathrm{c} ; 10$ lbs., $50 \mathrm{c}$; 25 lbs., $\$ 1.00 ; 100 \mathrm{lbs}$., $\$ 3.00$. These prices are not prepaid.

\section{Crushed Oyster Shell}

Hens must have lime in some form to furnish egg shell material If you are having trouble with your flock laying soft or thin shelled eggs and should start feeding Oyster Shell immediately to remedy this condition. Our shell is not ground from shell deposits but from shells from live oysters. Therefore there is more lime carbonate and less waste. 5 lbs., $20 \mathrm{c} ; 25 \mathrm{lbs} ., 60 \mathrm{c} ; 100 \mathrm{lbs} ., \$ 1.25$, not prepaid.

\section{Crysco Lime Grit}

A clean, sharp grit containing elements both helpful and necessary for the proper nutrition of food and production of eggs. It is gray in color and contains no dirt, causing no waste. Please state whether you want fine or coarse, when ordering. 5 lbs., 15c; 12 lbs., 25c 25 lbs., 40c; 100 lbs., $\$ 1.25$, not prepaid.

\section{Charcoal}

Charcoal is a conditioner and not a food. It absorbs impurities and carries them from the system. It may be mixed with scratch feed or fed in feeders. We have three sizes: Hen Size, Chick Size and Powdered. 3-lb. bag., 25c; 50 lbs., \$1.50, not prepaid.

\section{Feeding Tankage}

Hogs require animal feed and the lack of it will cause them to kill chickens or eat their young. Tankage is a hog feed and produces marvelous results when mixed with other feeds. Protein, 50 per cent. Per 100 lbs., \$4.00. Write for prices on larger quantities.

\section{Meat Meal}

This is a variety of meat feed that is very popular. It is ground fine and can be included in mashes. We can furnish this feed praclbs.. \$2.10; 100 lbs., $\$ 4.00$, not prepaid.

\section{Meat and Bone Scraps}

This is a high class meat product prepared from animal matte that has not decomposed. Contains 50 per cent protein and will compare favorably with the best products of this nature. 5 lbs, 30c: 10 lbs., 60 c 25 lbs., $\$ 1.25$; 50 lbs., $\$ 2.10$; 100 lbs., $\$ 4.00$, not prepaid. 


\section{Stock and Poultry Remedies and Supplies \\ Bird Food \\ Water Glass Egg Preserver}

Canary, recleaned, imported.

Dwarf Essex Rape, fancy recleaned...

Hemp, Manchurian, fancy...

Mixed Bird Seed.

Bird Millet.

Bird Sand.

Sunflower, recleaned, for Parrots

Cuttle Fish Bone, 5c to $10 \mathrm{c}$ each.

Bird Manna.

\section{Carbola}

Is a disinfecting white paint that paints and disinfects, and dries white. Can be used as a paint or powder and may be sprayed, brushed or dusted.

Prices: Not prepaid, 5 lbs., 75e; 10 lbs., \$1.25; 20 lbs., \$2.50; $50 \mathrm{lbs} ., \$ 5.00$,

TO APPLY DRY use the Feeney Duster, page 92.

TO SPRAY, use Hudson Compressed Air Sprayers, page 93.

Whitaker's Dip and Disinfectant

Prices, not prepaid: Pint, $40 \mathrm{c}$; quart, $75 \mathrm{c}$; $1 / 2$ gallon, $\$ 1.10$; 1 gallon, \$1.75 each; 5-gallon cans, $\$ 1.50$ per gallon; 50-gallon drums, $\$ 1.25$ per gallon.

\section{Pyru}

Prices, not prepaid: Pint, 75c; quart, $\$ 1.25 ; 1 / 2$ gallon, $\$ 2.00$; gallon, $\$ 3.50$ each; 5 -gallon cans, $\$ 3.00$ per gallon.

\section{Denver Fly Chaser}

Prices, not prepaid: 1 gallon, $\$ 1.50$ each; 5 gallons, $\$ 1.35$ per gal.
Water Glass is recommended by the Department of Agriculture of We United States as being a very simple, economical and safe method for the preservation of eggs. Preserve eggs when plentiful and be prepared for a scarcity when your hens take a rest.

Put the eggs in a crock or jar and mix the Water Glass with water that has been boiled, using 12 parts of water to 1 part Water Glass, and pour it over the eggs. Be sure to see that all eggs are
covered with the mixture. Eggs if allowed to stay in this solution, will keep fresh for one year-it's good, try it. Price, pt., 25c; qt. $40 \mathrm{c} ; 1 / 2 \mathrm{gal} ., 75 \mathrm{c} ; 1 \mathrm{gal}$., $\$ 1.25$, not postpaid.

\section{Pratt's Poultry Regulator}

25-oz. pkg., 30c; 4-lb. pkg., 60c; 12-lb. bag, $\$ 1.75 ; 25$-lb. bag, $\$ 3.00$ 100 -lb. bag, $\$ 10.50$, not postpaid.

\section{Pratt's Powdered Lice Killer}

$1 \mathrm{lb} ., 30 \mathrm{c} ; 21 / 2 \mathrm{lbs} ., 60 \mathrm{c}$, not postpaid.

Pratt's Poultry Disinfectant

Don't risk heavy loss that can be easily prevented. 1 pt., $45 \mathrm{c}$ 1 qt., 70c; 1/2 gal., $\$ 1.20$; 1 gal., $\$ 2.00$, not postpaid.

Pratt's Special Compound

Small pkg., 30c ; medium pkg., 60c, not postpaid.

Pratt's Roup Tablets and Powder Small pkg., 30c: medium pkg., 60c; large pkg., \$1.20, not postpaid. Pratt's White Diarrhea Tablets

Small pkg., 30c: medium pkg., 60c, not postpaid.

Pratt's Head Lice Ointment

\section{Achillea}

Acroclinium

Adonis ....

Ageratum

Alyssum

Amaranthus

Anchusa

Anthemis

Apples

Asparagus

Asters

Baby's Breath

Bag Balm

Balsam

Barley

Beans

Bedding Plants

Beets

Blackberries

Black-Eyed Susan

Blatchfords Products

Bleeding Heart

Browallia

Broom Corn

Buckwheat

Butterfly Bush

Cabbage

Calendula

California Poppy

Calliops is

Candytuft

Canna

Canterbury Bells

Carnation

Carrots Bean

Catalpa

Cauliflower

Celeriac

Celery

Centaurea.

Cherries

Chervil

Chicory

Chinese Woolflower

Chives ..........

Clematis

Cloves

Clovers

Cockscomb

Columbine

Coreopsis

Corn

Corn Salad

Cosmos

Cress $\ldots . . .$.

\section{INDEX}

Currants

Dahlia

Daisies

Dogweod

Du Bay Products

Egg Cartons

Eggplant

Elder

Endive

Endive $\ldots \ldots \ldots . . . .$.

Everlasting Sweet $\mathrm{P} e$

Farm Seeds

Fertilizers

Feterita

Feverfew

Flowering Aimond

Flowering Crab

Flowering Plum

Flowering Quince

Flower Seeds

Four O'Clock

Foxglove

Fungicides and Insecticides 86,65

Gaillardia

Garden Tools

Geranium

Globe Amaranth

Godetia

Golden Beil

Golden Glow

Gooseberries

Gourds

Grapes

Helichrysum

Heliotrope

Hibiscu.

Hollyhocks

Honeysuckle

Horseradis

Hotcaps

Hyacinth Bean

Hydrangea

Implement

Insecticides

Iris

Japanese Hop

Job's Tears

Johnson Grass

Kaffir Corn

Kale

Kerria

Kohl-rabi
Kow-Kare .

Lace Flower $. . \ldots \ldots \ldots \ldots . .47$

Lantan

Larkspur

Lawn Grass Seeds

Leek

Lettuc

Lilac

Linden

Lobelia

Maple

Marigold

Matrimony Vine $. . . \ldots \ldots \ldots, 62$

Maurandia

Millet

Milo Maiz

Mint ......

Moonflower

Morning Glory

Mountain Ash

Mourning Bride

Mushroom

Muskmelon

Mulberry

Nasturtiums

Nemesia

Nicotian

Oak

Oats

Olive, Russian

Onions

Pansies

Parsnips

Peanut

Pears

Peonies

Peppers

Perennial Plant

Petunia

Phlox

Pinks

Poplar

Poppies

Portulace

Poultry Supplies

Privet

Pumpkin

Radishes

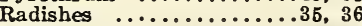

Rape .......

Remedies
Rhubarb $\ldots \ldots \ldots \ldots \ldots \ldots 37,42$ Rose of Sharon . .........6.60 Roses $\ldots \ldots \ldots \ldots \ldots .61,63,64$ Rutabaga $\ldots \ldots \ldots \ldots \ldots \ldots \ldots$. 40

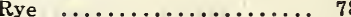

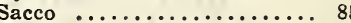
Sage $. . . \ldots \ldots \ldots \ldots \ldots \ldots, 4$

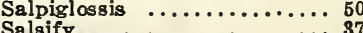

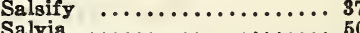
Salvia $\ldots \ldots \ldots \ldots \ldots \ldots \ldots \ldots \ldots \ldots$ b0 Scarlet Runner Bean ...... 50 Seed Disinfectants .... 86, 87 Semesan $\ldots \ldots \ldots \ldots \ldots \ldots .87$ Shade Trees $\ldots . . . \ldots \ldots \ldots \ldots .6 \%$. 59 Shasta Daisies ............6 6

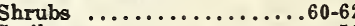

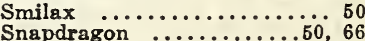
Snapdragon $\ldots \ldots \ldots \ldots \ldots \ldots, 66$ Snowball $\ldots . . \ldots \ldots \ldots \ldots \ldots, 61$ Snowberry $\ldots \ldots \ldots \ldots \ldots \ldots .61 . \ldots 6$

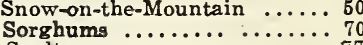
Speltz

Spinach

Sprayers and Dusters ... 92, 93

Statice $\ldots \ldots \ldots \ldots \ldots \ldots \ldots, 6,65$

Stocks $\ldots \ldots \ldots \ldots \ldots \ldots \ldots \ldots$
Strawberries

Sudan Grass $\ldots \ldots \ldots \ldots \ldots \ldots, 68$

Sumac .................. 61

Sunfowers $\ldots \ldots \ldots \ldots \ldots \ldots \ldots 2,5$

Sweet Rocket $\ldots \ldots \ldots \ldots \ldots$. 51

Sweet Scented Shrub .......6 61

Sweet William ..........51, 65

Sycamore $\ldots \ldots \ldots \ldots \ldots \ldots \ldots$. 59

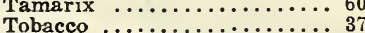

Tobacco $\ldots \ldots \ldots \ldots \ldots \ldots \ldots \ldots, 39,41$

Tomatoes $\cdots \ldots \ldots \ldots \ldots \ldots .38,4$

Transplanting Bands ...... 93

Tritoma $\ldots \ldots \ldots \ldots \ldots \ldots \ldots, 65$

Tuberose........

Vegetable Plants and

Roots $\ldots \ldots \ldots \ldots \ldots . . .41,42$

Vegetable Seeds $\ldots \ldots \ldots \ldots \ldots 2-40$

Verbena $. . . \ldots \ldots \ldots \ldots \ldots .61,66$

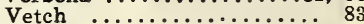

Vines

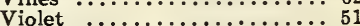

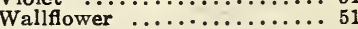

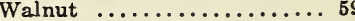

Watermelon $\ldots \ldots \ldots \ldots \ldots \ldots .23$

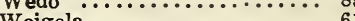

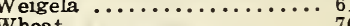

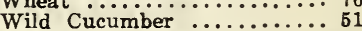

Willow $\ldots \ldots \ldots \ldots \ldots \ldots \ldots, 59$

Wisteria $\ldots \ldots \ldots \ldots \ldots \ldots, 62$

Xeranthemum $. . . \ldots \ldots \ldots \ldots \ldots, 51$

Yucca $\ldots \ldots \ldots \ldots \ldots \ldots \ldots \ldots \ldots, 656$ 
Western Seed Company's

Own Strain of

True

\section{Giant Spencer Sweet Peas}

Everybody likes Sweet Peas and they are grown with so little care and bloom so profusely that the smallest garden should contain a good supply. See pages 52 and 53 for complete list.

Also see our Sweet Pea Collection at special prices, page 53 .

\section{The \\ Beautiful Asters}

Are among the most popular and easily grown of all our annuals. Turn to page 44 for complete description.
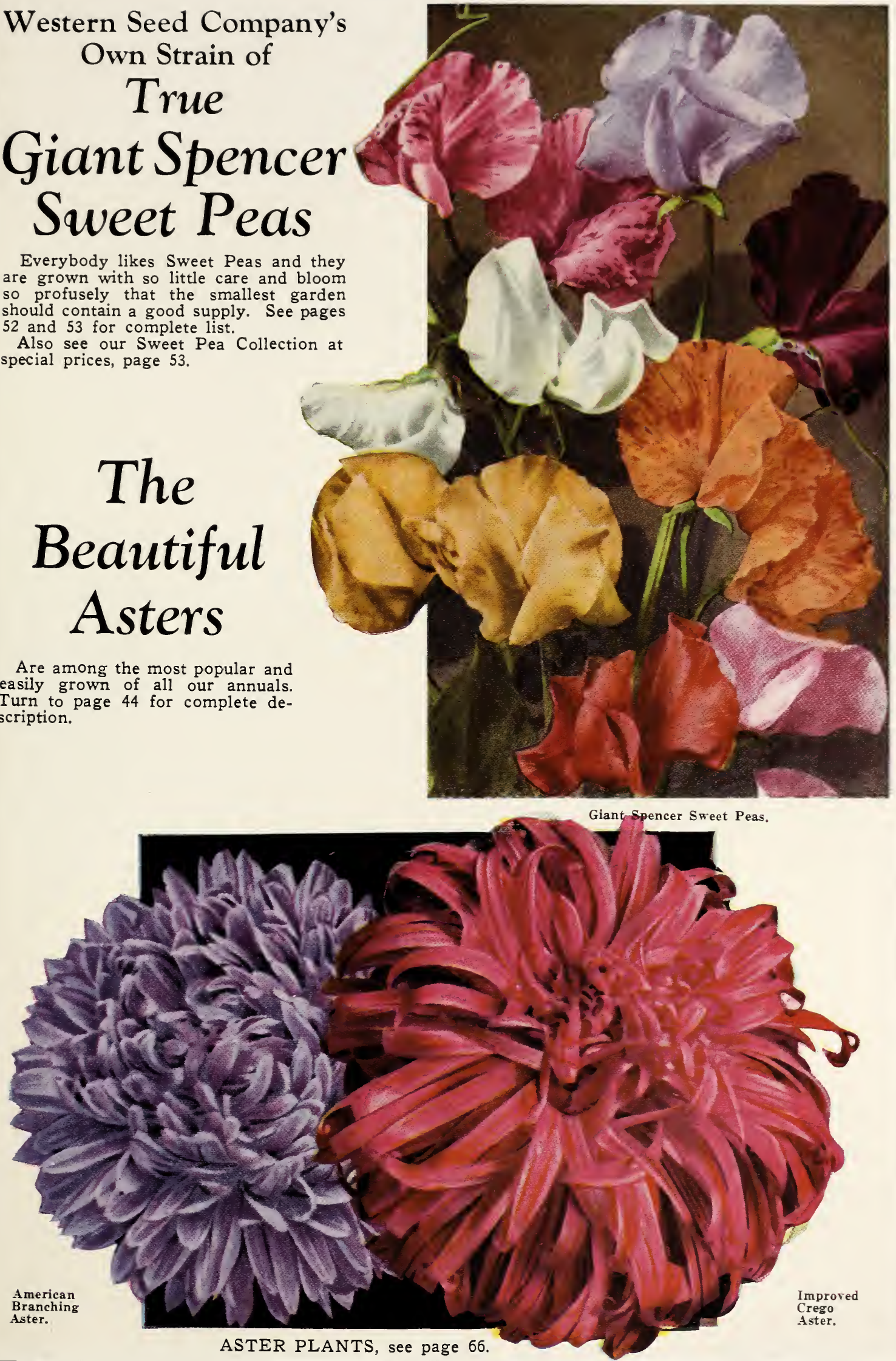


\section{Three Wonderful New Introductions for Mountain Growers}

No. 12 Extra Early Mountain Iceberg Lettuce

A strain of the best New York or Wonderful, but it is about ten days earlier, heads larger, more uniform and matures more evenly. (See page 21).

\section{Selected Alderman Peas}

This is a very carefully bred and selected strain of Alderman Peas bred up for productiveness, large size and color of pods. Especially recommended for mountain planting. (See page 31).
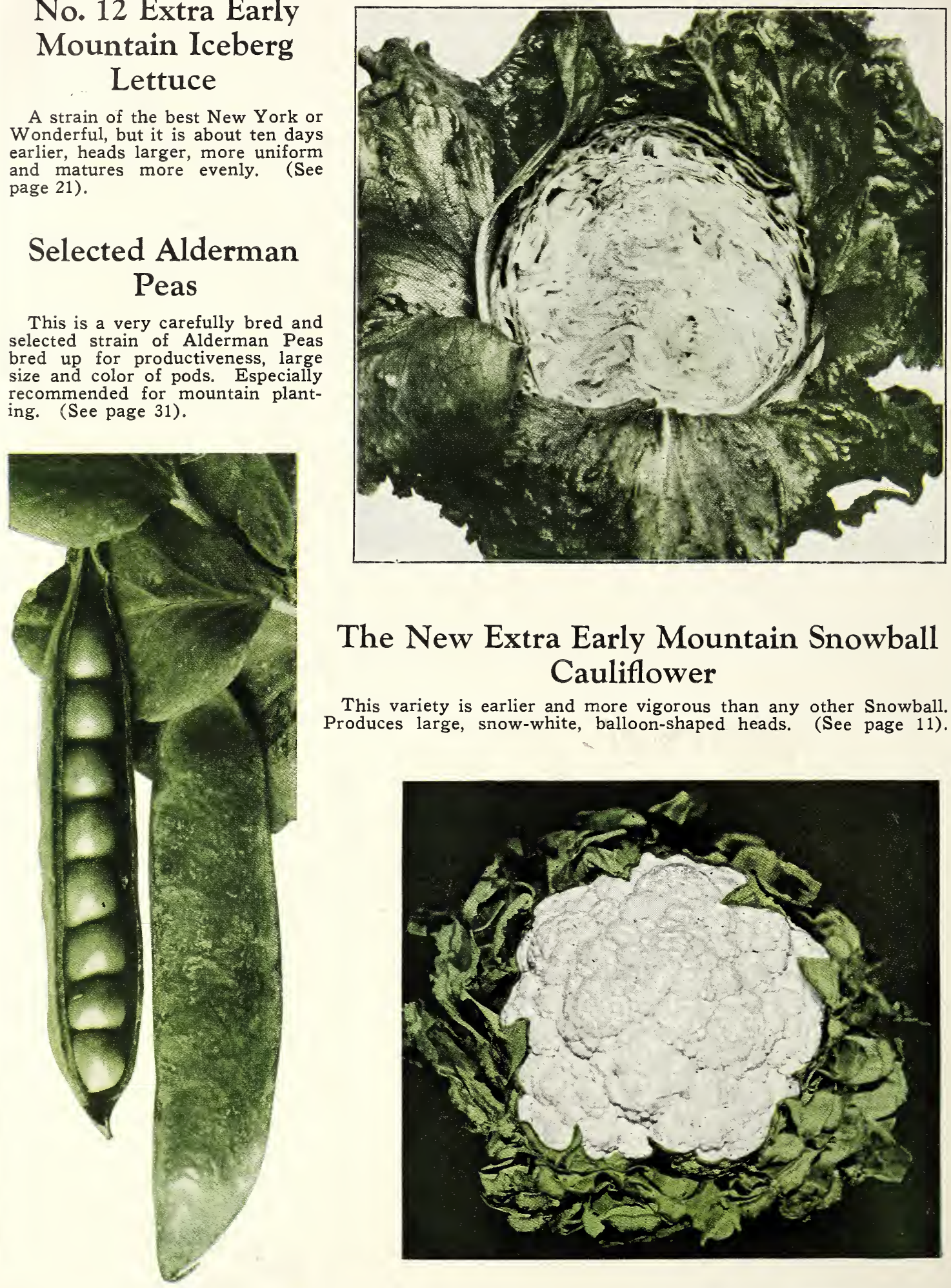

\section{The New Extra Early Mountain Snowball Cauliflower}

This variety is earlier and more vigorous than any other Snowball. Produces large, snow-white, balloon-shaped heads. (See page 11).

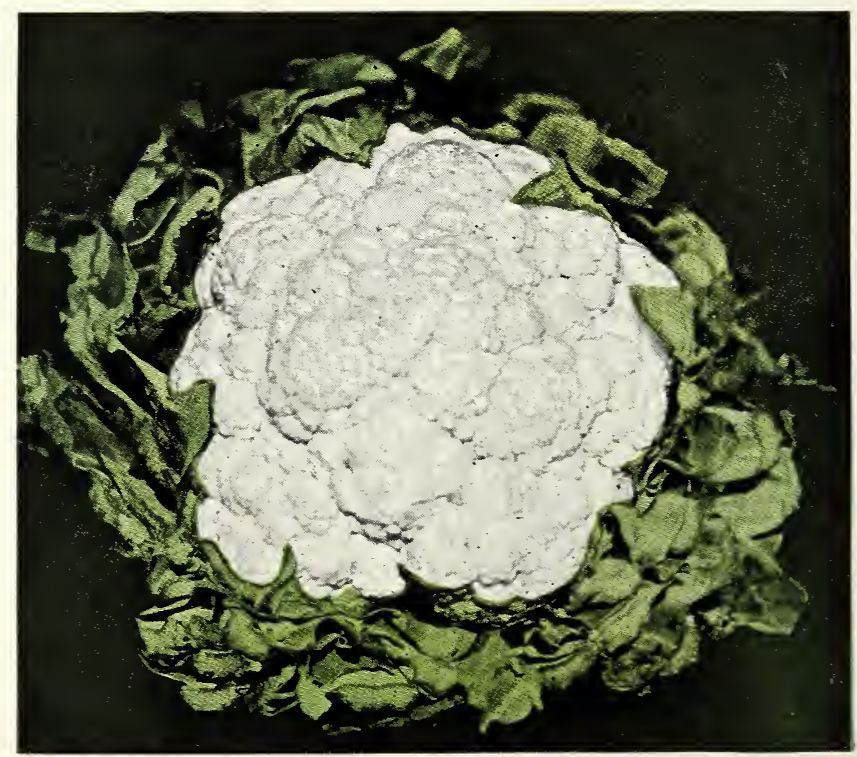

